STUDIES ON THE MORPHOLOGY, ONIOGENY AND EMBRYOLOGY OP THE TLOVIERS OF HEDYCABYA ARBOREA J.R. et G.Forst. (SUBEAMTLY WONI TOIDFAE) AND LAUREIA NOVAE-ZEZANDTAE A.Cunn. (SUBFAMILY ATH ROSPERMOTDEAT) OF THE FAMTLY MONIMTACFAE.

$$
\text { Volune } 1 \text { - TEXT }
$$

Thesis submitted in partial atisfaction of the requirements for the degree of Doctor of Phllosophy in Botany, at Victoria Unlversity of Wellington, Wellington, New Zealand.

By Frederick Bruce Sampeon. 1967 


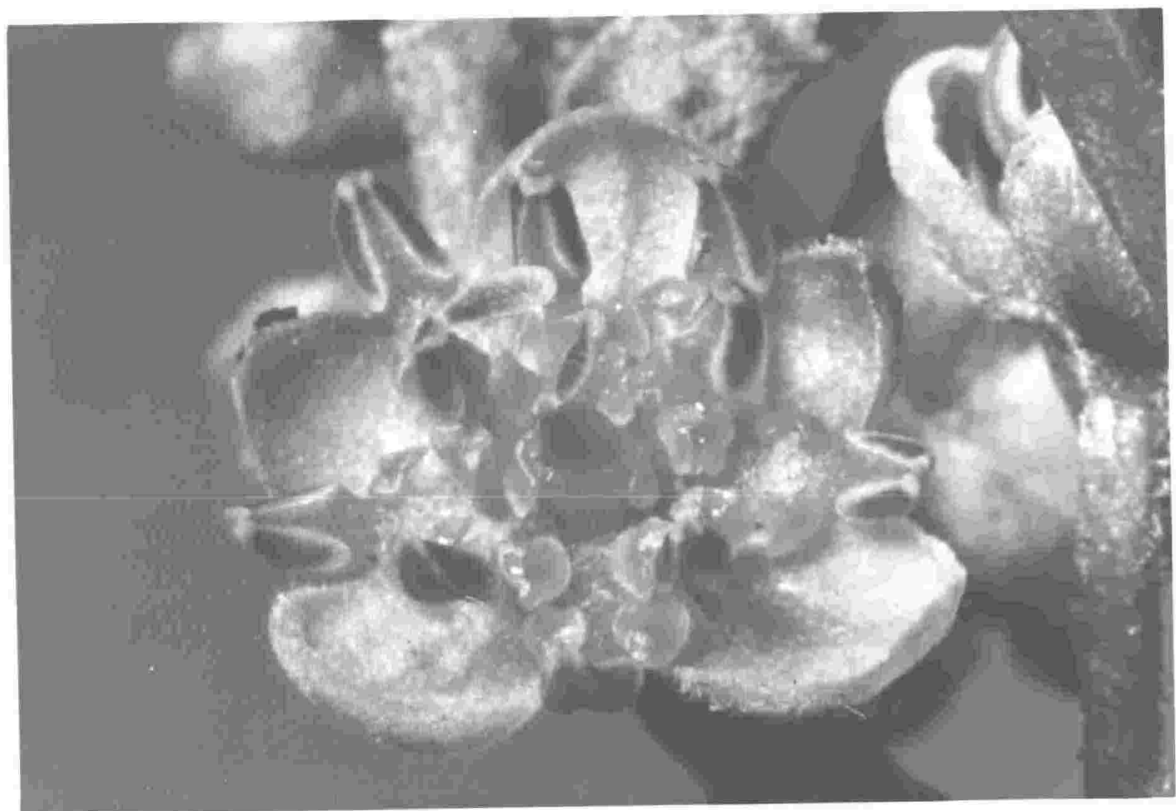

Hele flower - Laurelia novae-zelandiae X 8

MOTO 11.D. KIIVG 


\section{TABLE OF CONWETS}

VOLUME 1 - TEXY

ABSTRACT ......................... 1 ACKNOWLEDGRIENTS .................... Iv MATERIALS AND METHODS .................... 1 CHAPIER 1. Introduction ............ 5 GHAPTRE 2. The Inflorescences and Flowers ....... 11

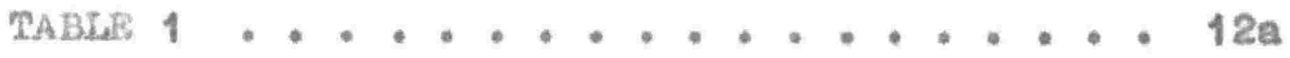

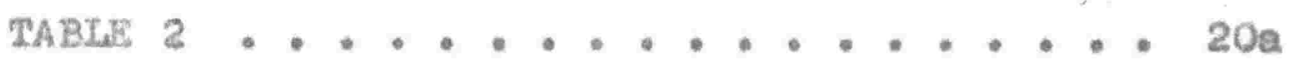

CHAPRER 3. Vegetative, Inflorescence and Floral Heristens 53 CHAPTER 4. Stamen Ontogeny and the Development of Mlerosporangia and hale Ganetophytes .... 70 CHAPTER 5. Ontogeny, strueture, Function and Morphological Nature of the Staminal Appendages of Laurella 100 CHA PTER 6. Carpel Ontogeny and the Development of Megasporangla ana Fenale Gametophytes . . 115 CHAPTER 7. Pollination, Fert111zation and Post Fert121 zation Stagea ......... 135 CHAPTRR 8. Concluslons .............. 140

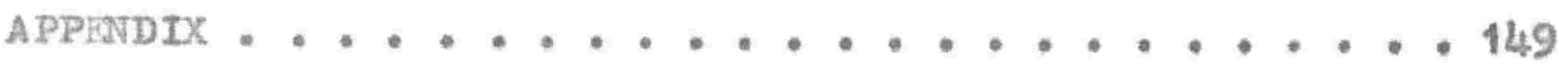

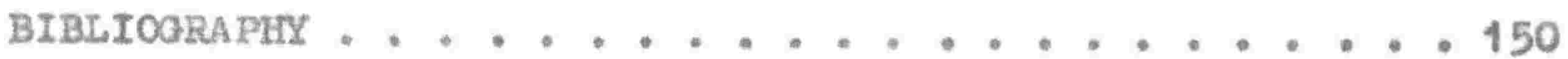




\section{ABSTRACW}

The inflorescences, flowers and the vascularization of Ioral parts of Hedycarra arborea and Laurel1a novae-zelandiae were deseribed and comparisong tade with other members of the family in an attempt to determine the basic types of inflorescences, flowers and floral vascularization in the fan1ly.

The vegetat1ve, inflorescence and floral meristems of the two genera were compared. It was concluded that the vegetat1ve apices of both had the tunica-corpus conflguration typical of many other woody Ranales and other orders. The inflorescence aplees were quite sinilas to the vegetative ones. The young foral apices are in a state of transition from a tunica-corpus to a mantle-core configuration and older floral aplces had the aantle-core conflguration, which 13 typleal of the floral apices of many woody Ranales. Unusuel features of the floral aplees of Hedycarya and Laurelis were the $1 \mathrm{ck}$ of a pronounced $\mathrm{rlb}$ meristem and the occurrence of relatively frequent divisions within vacuolate cells of the core.

The ontogeny of the atamens of Hedyearye and Laurel1e was described and comparisone were made. In both genera the alcrosporanglum developed in a slmilar fashion: in Hedycaryg 5-6 wall Layers are formed inside the epldermis; in Laurelia there are 3-5 layers. Both genera had a typically thickened endothecium and a tapetum of the secretory type in which the tapetal cells become binucleate auring the flret melotic division of the pollen 
mother cells. In Hedycarya the melotic atvisions of the pollen mother cells are of the auccessive type in which walls form by means of centrifugal cell plates. Pollen grains remain in permanent tetrads in this genus. In Laurella wall formation at the end of meiosie 1 is of a modifled almultaneous type, which may not have been hitherto described in the ilterature. Pollen grains are not in permanent tetrads. When the first division occurs In each microspore in Hedycarya, all four cells of a tetrad are at the same stage of division and the generative cell $1 \mathrm{~s}$ cut off towards the distal face of the graln. Bach microspore ia in the two celled condition when shod. It was deduced that the generative cell is cut off agalnst what represents a radal wall of the grain (with reference to the tetrad stage) in Laurelia. Pollen is shed in elther the two or three celled condition. Comparisons were made with the development of mlerosporangia and male gametophytes in other woody Ranales.

A study was made of the ontogeny, structure and function of the staminal appendage of Laurel1a. It was found that the appendage function as nectarles, the nectar belng predominantiy sucrose. After a discuselon of the various theorles as to the morphologleal nature of the etaminal appendages of the Laurales, It was concluded that they are morgholog 1 cally staminodes.

The carpels of Eedycarya and Laurelie have a baslcally ginllar ontogeny in which, as in the Lauraceae, the terminal stigmatic region develops fron a solld terminal meristem in contrast to 


\section{1}

many woody Ranales in which the stigmeconglats of crests which surround the external part of the cleft of the carpel. The ovules of Hedycarva and Laurella resemble those of most other woody Ranales in being bitegmic, crassinucellate and antropous with a nonosporic 8mucleate embryo sac of the Polygonum type. Both 11 near and $\mathrm{T}$-shaped megagpore tetrads were found in the two genera.

Laurells has pseudocarps which develop after anthesis and enclose plumose achenes, but in Hedvearys the fruits are drupes. It was concluded that Laurella and Hedvearve belong to two subfanlles which have been separated from each other for a long t1me and have undergone considerable evolution in alfferent directions. It was also concluded that the Monlmiaceae are closely related to the Lauraceae. 


\section{ACKNOWLEDOEMENTS}

I especially wish to thank Frofessor H.D. Gordon, Botany Department, V.U.W., for advice and encourageaent during the course of this study and for exitielsing a draft of this work. I especially thank too, Dr. J.G. Albbs who, while acting-head of the Botany Department, granted me a term and a hali free from teaching duties. Without this free time my thesis would have taken a conslderably longer time to complete.

I wish to thank Dr. J.W. Dawson of the Botany Department for translating Waterkeyn's paper from the French and Mr. G.P. Chrifteller, a etudent of the German Department, for translating Mauritzon's paper from the German. I an Indebted to lix. G.K. Rickards of the Botany Department for valuable advice on some cytologlcal aapects of this work and for the loan of his camera for photomicrography. I wish to thank Hir. L. Gramaticopolo for making sections of the buds of shoot aplees of Hedycarre and Haurelis.

I tender thanks to Mr. M.D. King, University Photographer and Professor J.T. Salmon, Zoolody Department, for taking Bome excellent photogra he and thank the llultilth Printing Department, V.U.W., for printing 11lustrations and tables.

I an grateful for the time which Mr. LoR. Bublitz and my mother, Mre. M.C. Sampson, spent in collecting material for me and I wish to thank $\mathrm{k}$. Bublitz for allowing material to be collected from his property at New Plymouth. 
I would like to thank Mr. H. Johnston and MIss M. PrIday of the Botany Department for the chromatographic analysis of sugars.

I wish to thank Profeser eT.T. Salmon, Dr. P.F. Falph and Hr. Moper for permission to use and instruction in the use of the Zoology Department'g Zelss Photonicroscope.

I wish to thanik Mr. B.V. Sneddon for some advice on taxonomic work and for printing the photos of Atherosperme and porvohorg.

I whah to record my thanks to Dr. C.J. quinn and Mr. J. Waterhouse, Botany Department, Univerelty of New South Wales, for taking me to the Blue liountains to collect material of Hedycaryo angustifolla and Dorrohore sassafres. I wish to thank Mr. W. Sylses, Botony Divielon, D.S.I.R., for collecting frults and rower buds of Atherosperme fron the Chriatchurch Botanic Gardens. Dr. B.J. Godley, Botany Divialon, D.8.I.R., kindiy loaned me herbarium meclmens of Laurelia gerrata.

Finaliy, I wish to thank my wife for eneouragenent during the latter pert of this atudy and Mre. P. Cassels for her excellent typing. 


\section{WATERIALS AND HETHODS}

Collections were made for 2 years $(1963-4)$ at monthiy intervals or less and later $(1965-6)$ at more infrequent intervals, from a gingle Laurelia tree (a remant of native bush) on the property of $\mathrm{s} r$ and fre Bublitz, 19 Oriental Street, New Plymouth and from a male plant and a fenale plant of ledwearva growing on the fringes of native bush adjolning the Bublitz property.

Supplementary collections were made at sporadic intervals from a Laure 11 a at Pakuratah1 Forks, S.E. Tararua Range. Flowers were collected from trees on the western side of Lake Ponul, Western Walrarapa aistrict in late October and early November 1966. Additional materlal of Hedyearye was obtalned from Wilton's Bush, nellington and from the western side of Lake Wairarapa at infrequent intervals.

Unless otherwise stated, descriptions apply to the New Plymouth material.

The material was ixed and preserved in formalin-acetic-alcohol, aspirated with a vacuum pump as soon as possible after collection and after some months transferred to $70 \%$ ethanol to avold any possible hardenlng of tissues due to prolonged storage in $\mathbf{f} . \mathrm{a} . \mathrm{a}$. It was embedded in aurro $56^{\circ} \mathrm{C}$ m.p. parafin wax by the tertiary butyl alcohol method of Johaneen (1940) and sectioned with a Spencer rotary microtome at 5-12 $\mu$ thickness, according to the stage of development. Sections of vegetative buda were stained in gafranin and fast green; other sections were stained in 
Heidenhain's Lron haematoxylin according to the rapld method or Daxlington and La Cour (1960) and mounted in Canada balsam.

Both genera had Ploral bracta and brecteoles, peduncles and pedicels, perlanth parts, portions of the stamens, carpels (excludIng the stigmatic surfaces) and the floor of the receptacle, covered wh th long trichones whlch becone thlck-walled ab they mature. During eectioning some of the trichomes were deflected by the microtome knife causing damage to the sections. In order to obtain satisfactory sections, nost of the mature trichome had to be removed with the ald of a scalpel and dissecting microscope before the material was embedded. To slinplify this procedure, parts no longer required for study were exclaed e.g. nature perianth segments. The dense covering of trichomes on sub-mature and mature carpels could not be cut off without removing some of the underlying tissues and it was found less time-consuming to dissect out and embed the ovules, once sufficient stages in carpel growth had been sectioned. This lsborlous and peinstaking task seemed preferable to attempting to soften the trichomes by chemical means, which would $t$ enu to macerate the material. Nauritzon (1935) aleo found it necessary to renove halrs when studying the embryology of the carpel of Peumue (Honimiaceae). The trichones prevented the sectioning of whole inflorescences except at a very young atage in development. Approxlmately 100 buda of each sex, of each genus, were sectloned in order to obtain reasonably complete stages in the growth of flowers to anthesis. 
Information from section was supplemented by the alssection of material under a Zelss Opton aissecting microscope at magnifications of up to 160 times.

Preserved flowers were cleared in sodiun hydroxide to reveal their vasculature by the method of Balley and Nast (1943b).

Drawings of dissections were made with the ald of a Carl Zelss camera lucida with bulit-in polarizing filters.

Phot omlerographs were taken on Ilford Pan F $35 \mathrm{~mm}$. film (a) under ordinary 11 ght with an Asahi Spotmatic camera mounted without lens to a Lestz Laborlux microscope (b) under ordins light and phase contrast w1th a Carl Zelss Photomicroscope.

All photographs were taken by the author unless otherw1se stated.

The method used for testing for sugars in the exudate from the staminal appendages of Laurelia $1 \mathrm{~s}$ described in the appenaix.

I collected the following aterial from Australla and Tamania in order to compare the flowers of Laurelia and Hedvearve arborea with those of ame other members of the Nonimiaceae:Atherosperma moschata Iabili. (syn. Atherosperma moschatum Lab111.) Male and carpellate flowers and flower buds were collected from trees of this monotyple genus in Hount Fleld National Park, Tasmania on $21-8-65$.

Doryphore saseafras Endi. Flowers and flower buds were collected from trees of this monotyple genus growing near Bowens Creek, Blue Mountains, New South Wales on $29-8-65$. 
Hedycarya angustifolia $A$. Cunn. Flowers and flower buds were collected from male and female trees on llount Wilson, Mue Nounta1ns, New South wales on 29-8-65. 


\section{INTRODUCTION}

There has been renewed Interest in the morphology of the woody Ranales in recent decades, Iollowing the flnding of apparently primltive leaf-like stamens and carpele within the group, which began with the alscovery of Degeneris (Bailey and Smith, 1942; Smith, 1949; Swany, 1949). Thie Led Balley, Smlth, Swany, Nast and comorkers at Harvard University to a deta1led re-investigation of the comparative orphology of many fanllies within the woody Raneles, Including the Honimiaceae. They found primitive types of wood anatomy, phloem structure, nodal anatomy, embryo development and pollen (some of the pe primitive features had been known in this group for some tine) and atages in the phylogenetic development of more advanced types. In addition they discovered phylogenetic stages in the development of the leaf-like stamens, carpele and perianth parts leading to the more conventlonal flowers in the woody Ranales and other orders. References to, and aumaries of, this work ean be found in Eames (1961). These Invest1gations were mostly based on studies of adult material, frequently reexpanded from herbarium apecimens.

Subsequently more detailed studies have been made by a number of botanlets, frequently on Indvidual species or small groups of related genera. These otud1es, which were often ontogenetic in nature, using properly preserved material, in general conflrmed 
and extended the earlier work. They lncluded studies on the structure and development of shoot apices of certain woody Ranales (G1fford, 1950); studies on the stamens, polien, carpels, Iloral aplces and vegetative shoots of the lagnoliaceae (Canright, 1952 $a \& b, 1960,1963$; Tuciker, 1960, 1961, 1962, 1963); atudies on the ontogeny of inflorescences and ontogeny and vascularization of flowers of the interaceae (Tucker, 1959; Sampson, 1963; Tucker and afford, 1964, $1966 \mathrm{a} \& \mathrm{~b})$; studies on the ontogeny of the lear and vegetative axillary bud of one of the vinteraceae (G1fford, $1951 \mathrm{a} a \mathrm{~b}$ ); on the morphology of the Lectoridaceae (Carlquist, 1964); on the flowers of the Nymphaeacear (Moseley, 1958, 1961, 1965); on the pollen morphology of some ranalean fanilies (Canright, 1963) and on the morphology of leaves, apices and flowers of two member of the Lauraceae (Kasapl1g12, 1951). There has been an increasing acceptance during this centu $y$ that the Ranales and their allies are the most primitive anglosperms (Hoseley, 1965). However, the Ranales are undoubtably a heterogeneous assemblage, which as Eames (1961) states, are held together by the possession of several prinitive characters and "the families seem to be an assortment of relic types, representing several ancient lines rather than a single basic atock. Archaic characters have been retainea but are combined with well, even highly, advanced structure" •

Introduction to present study

I was attracted to a atudy of $120 \mathrm{or}$ morphology within the 
Honimiacere in that this family appeared an interesting one, on the fringes of the woody Ranaler. It posseased considerably more advanced florel structure than Peeudowinterg of the Winteraceae, which I had studied previously (Sampson, 1961, 1963). Furthermore, two genera, Hedvearya and Leurelia, were readly accessible as they occur within the native llora of New Zealand. The genera are in alfferent subfamilies and seemed at least superficlally quite dissimilar in floral structure. An additional consideration was that there have been fow atudies on floral morphology within the fan1ly, but a recent comparative atudy of the morphology and relationships of the various genera in the family by Money, Bailey and Swamy (1951) provided a good basls from which a detalled study of the floml ontogeny, morphology and embryology of the two genera could be made.

Honey et al. (1950) concluded that "the Monimiaceae is a key family in understanding and in interpreting the morphology, not only of the Lauraceae, Gomortegaceae, and Hernandiaceae, but also of the Chloranthaceae ..... and probably other alcotyledonous fanilieg". The Monlmiaceae has long been considered closely related to the Lauraceae and in the latter family a number of studies have been made on rloral development in various genera (see Sastri, 1958). There studies ineluded, In addition to those of a primarily embryological nature, a Ph.D. study of the aplces and flowers of two genera (Kasaplig11, 1951). Kasapl1gil pald particular attention to the vascul r anatomy of the flowers and 
to the nature of their staminal appendages which have been variously interpreted. This work was of great intereat to me, as Laurelia possessed apparently analagous staminal appenajages and the considerable embryological studies in the Lauraceae provided a basis whereby conparisons could be made with the embryology of Hedycarva and Laurelis.

Brevious relevant studies ir the Lonimiacere

(a) Perkins and Gilg (1901) and Perkins (1911) had provided a detslied description of the genera and apecies in the Monimiaceae, as part of "Das Pllanzenrelch". These descriptions totalled almost 200 pages.

(b) Heilborn (1931) described the exbryoloy of the female plant of a species of siparuna, a genus which Money et al., (1950) placed together $w_{1}$ th two other genera, in a separate subfamily, the S1parunoideae. Hellborn's results indicated a unique and anomalous type of embryology (see chapter 6).

(c) Hauritzon was attracted by the unusual results of Hellbom and therefore studied the enbryology of the fenale flower of Eeumus, a genus which Money et al., (1950) incluâed, together with Hedycerva and some other genera, in the subfamily foninioldeae. Hauritzon's (1935) results 1ndicated nothing very unusual in the embryology of peumus.

(d) Money et al's (1950) study compared the leaves, stem anatomy, nodal anatony and flowers of the various genera of the family and the authors made sone taxonomic changes including the 
removal of some genera from the family. Alms of the present study

(a) To describe and compare the structure of the inflorescences and flowers of ledycarye and Laurelig, incluaing the vascularization of floral appendages and to make comparisons where posslble with other members of the family and of related families in an effort to interpret the relat1ve stages of evolution of the valous Ploral parts, compared to other woody Ranalea.

(b) To describe and compare the vegetative, inflorescence and floral meriatere of the two Genere and to make comparisons With similar studies on other ranalean genera.

(c) To describe and compere the ontogeny of the stamens and the development of the terosporangla and male gametophytes of the two genera and to interpret these results in relation to simllar gtudies on other woody Ranales.

(a) To study the ontogeny, structure, function and morphologieal nature of the staminal appendages of Laurelis and to make comparlsons w1th Kasapligil's studies on the staminal appendages of Laurus and Umbeliularia of the Lauraceae.

(e) To describe and compare the ontogeny of the carpezs of Hedrcarve and Laurelia and to interpret the $1 x$ nature in the 11ght of the trends of carpel specialization which Balley and Swamy (1951) have groposed for the woody Ranales.

(f) To describe and compare the development of the megasporangia and female gametophytes of the two genera and to 
interpret the resulta in relation to studies on related genera.

(g) To assess the relationehipg of the Monlmiacese in view of the results obtalned from this thesis.

Distribution of Hedycarva and Laurelia

Hedycarys is a genus of 25 species (w1111s, 1966) which occur mainly in New Caledonia but also in Australasia, Fiji, Samoa and the Solomon Islands (Allan, 1961; Perkins and G118, 1901; Perk1na, 1911). Laurelia comprises 2 (W1111s, 1966) or 3 (Perkine, 1911; Money et al., 1950) species one of which occure in New Zealand and the other one or two in Chlle. Hedycarva arborea, the sole New zealand specles of the genus, occurs throughout the North and South Islands and on Three KIngs Island, In lowland to montane forest (Allan, 1961). Laurella novaezelandiae occurs in lowland semi-swamp and gully forest and is distributed throughout the forth Island and extends to latitude $42^{\circ}$ on the east and $46^{\circ}$ on the west of the South Island (Allan, 1961).

Laurelia (aff. novae-zelandige) pollen appeared in the fossil record of New Zealand in the Waltakian Stage (m1dale 011gocene), according to Couper (1960). Berry (1935) recorded that macrofoss1la of Laurel19 have been found from Tertiary strata in South America and Seymour Island. Ledvearve has not been recorded In the fossil flora of New Zealand. Four species of this Eenus have been recorded froli the 011gocene and $k$ locene of Europe and a fifth from the Tertiary of Australia (Berry, 1935). 


\section{THE INELORESCW CES AND FLONTS}

Introduction

Hedycarya arbores is dioeclous (Allan, 1961). Allan

described Laurelis as being dioecious to polyganous, deflning the latter term as "bearing unisexual and blsexual plowers on the same plant". Hermaphrodite flower of Laurelia novae-zelandige have been described as belng similar to the female, but with "sone or all of the outer row" of stamens perfect (Cheeseman, 1925). Male flowers lack rudiments of carpela.

I have examined 20 Laurelia trees in various localities (New Plymouth, Pakuratahi Forks, Lake Ponus and Kapit I Island) and all were polygamous. A,1l plants had many more male flowers than other $t$ ypes. Inflorescences were elther wholly male or mixed, never of wholly femele andor hermaphrodte flowers in the several hundred inflorescences which I exanlned. Some trees had a ratio as $\mathrm{high}$ as approximately 100 male flowers to every 1 fenale or hemaphrodite flower. It 1 s possible that a larger sampling mleht reveal thale trees but it does not seem likely that trees exist with only female and or hermaphrodte flowers. Thus, results indicate that this species is not truly aloeclous. The female and hermaphrodite flowers are very simliar in structure and present a problen in terminology. Both contain ataminodes which becolse progressively reduced towards the centre 
of the flower. The hermaphrodite Ilowers have in addition, external to the staminodes, one or more functional stamens. Similarly, in the related monotyple Atherosperma moschata, $1 t$ has been noted that the somerlled fenale flowers have "the outer row consisting of staminodia, and often ( In Tasnanla) developing perfect anthers 1 in 2 or 3 or then" (Rodway, 1903). Not infrequent1. in Laureliag, one or more of the outermost staminodes in the female or hermaphrodite flowers undergo dehiscence but their pollen sace contain abortive pollen. Sometimes too, in the stamens of male and hemmaphodite flowers, one of the two pollen sacs is full of abortive pollen and this sac may or may not undergo dehiscence. It 18 concluded that there is an unstable transition stage in the evolution from an hermaphrodite to a female flower. Hermaphrodite flowers were of greater abundance than female ones. For example 38 out of 50 carpellate flowere, chosen at random, had one or more functional stamens. Money et al., described the flowers of Laurelia sempervlrens (Rulz \& Pav.) Tul. and erroneously those of $L$. novge-zelandise, as belng invariably unisexual. They found that the flowere of Laurel1a serrata Phil. had "In addition to functional carpels, two or more stamens with sporangla that contain fully developed pollen". They examined limited material and I would think. It possible that all 3 apecies have both hemaphrodite and Peale flowers. For simplicity, I w11l in general refer to both the female and hernaphrodite flowers as carpeliate. 

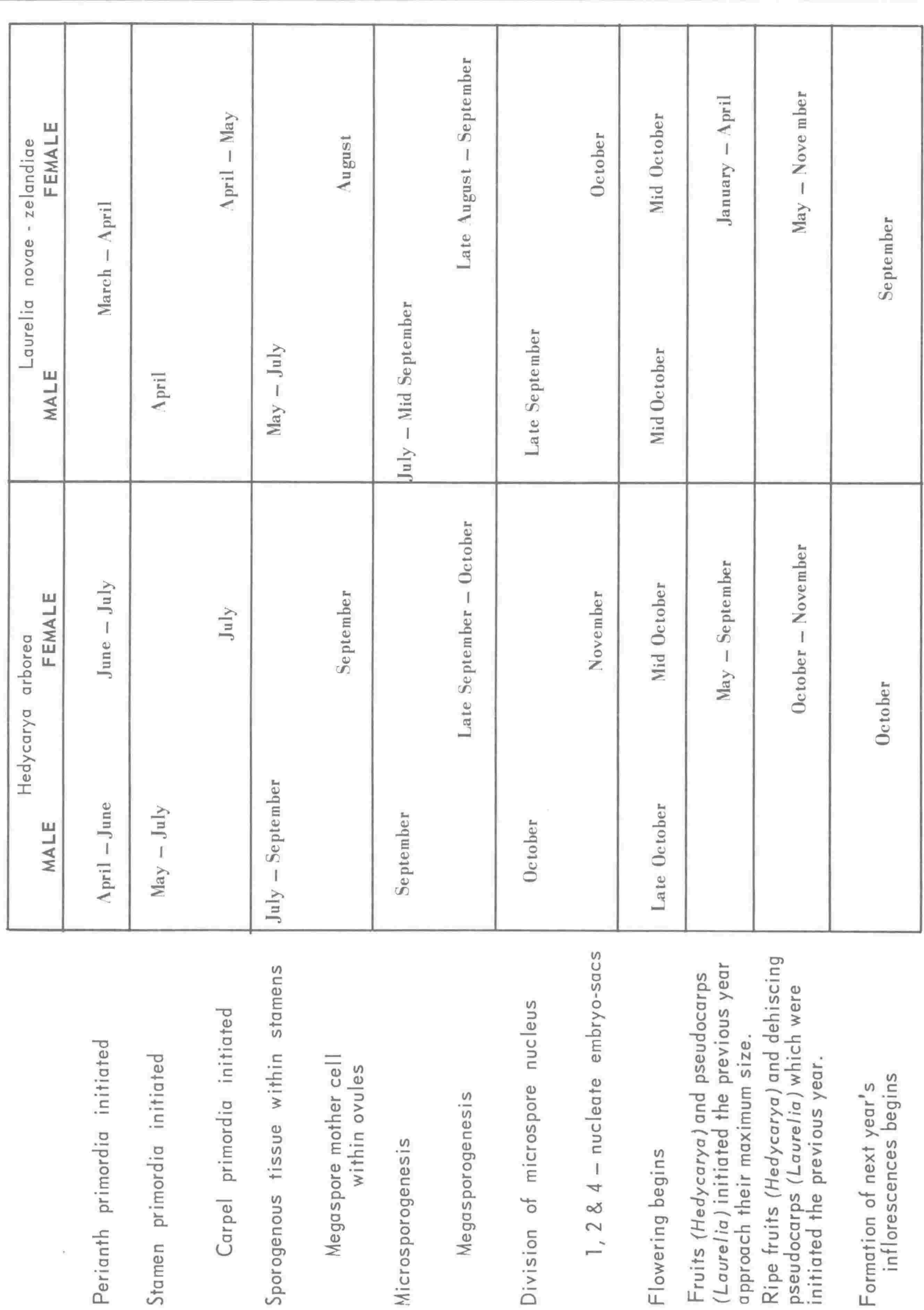
Stgges in 11 ower develooment

Table I sumarizes stages in 12 oral development. The three trees were growing within 50 yards of one another and occupled similar habitats with respect to slope, aspect, altitude and presumably soll type, thus enabling meaningful comparisons to be made. No simificant differences were noted in the times at which particular events occurred from one year to the next. For example collections of Laurelia on 29-8-63 and 29-8-64 both contained some carpellate flowers with megapore mother celis at prophase I and some male flowers with stamens undergoing microsporogenesis. Slmliarly, collectlons of Hedvearya on 21-10-63 and 17-10-64 contained some female flowers with megaspore mother cells at prophase I and some sale nowers in which the unicellular microspores were dividing. Furthermore, in Laurelia, no significant differences were found in the tines at which various events occurred in the stamens of male flowers compared with those of hermaphrodite 1 owers. On 28-9-64 for example, some male and some hermaphrodite flowers had stamens with microspores undergoing their Plrst division.

The following points are relevant to the Table:-

(a) Some range of developmental stages of stamens and carpels may be present at one time, although not within a singie flower, except during the time when primorala axe being successively initiated. For example vone Laurelia 12 owere collected on 14-7-63 had stamens in which the sporogenous tissue was at111 dividing 
whereas others had stamens undergoing microsporogenesis. (b) Floral development continues throughout the winter, in contrast to those temperate climate plants with 1 owers which are quiescent duxing the midale of winter e.g. Drimys lanceolata (Tucker and Oifford, 1966a).

(c) During October three stages are present on Laurella and female Hedrearya trees:- open 1 owers, mature frults fron the previous year's 1 owers and young buas of the followlng year's flower.

(d) Perianth primordia are indtlated somewhat earlier in the male Hedyeara flowers although the ferale flowere begin flowering about two weeks before the males. However the ovules are not mature at anthesis and fmature (4-nucleate) embryo sacs were not found unt 11 mid-November at which time male plants were in full flower.

(e) It 18 stated in the Table that formation of the next year's Inflorescences begins in Septesiuer (Laurelia) and October (Hedycasya). These dates need qualification as they rofer to the tiwe at which the inflorescence buds are vialble in the axils of leaves which have recently expanded from the bud atage (PIATE 1, Ilg. 1 , uppermost pair of apreading leaves). Actual initiation of inflorescence primorala, in the axils of leat primorala within the bud, would have occurred at an carlier date. Structure of inflorescences

Allan (1961) described the inflorescences as "axillary eymes 
or racemes". Nelther of these terms, in their usual senge, accurately deseriber the 1nporemcences. In both genera the inflorescence arisea in the axil of a leaf, or rarely leaf-scar, and consists basically of an axis bearing a number of decuseately arranged pedicellate flowers, exch of which arises in the axil of a bract*. The axis teminates in a flower (PLATE 1, PIg. 2) which tay, or may not, be subtended by a bract or palr of bracts. Some inflorescences are compound, with a secondary axis arialng In the axil of one or more of the lower bracts (PLATE 2, 11g. 1). Fach of these secondary axes usually consists of two flowers forming monochasium (PLATE 2, $1 \mathrm{~g}$. $3 \hat{k}$ or three flowers, forming a dichasium (PLATF 2, Plg. 1). Sometimes a eecondary axis resemblea the prinary axis and bears severel palrs of decussately arranged flowers and terminates in a rlower. Most bracts absciss shortly before anthesis, although the lowest palr may be tare persistent.

The following variations were noted in the structure of Inflorescences:-

(a) One or both of the lowest (proximal) palr of bracts, and rarely bracts elsewhere, may not abtend a flower or inflorescence.

* Brict is used in the sense of a reduced leaf-like structure which subtends an inflorescence or flower or is preaent on the flower stalk or on the floral receptacle below the perianth parts. liany writers regard a bract as a leaf (whether reduced or not) In the axil of which a flower arises and a bracteole (prophylum) as simliar to a bract but ariaing on the flower stalk 1tself (e.8. Rendle, 1930; Wlilis, 1955; Lloyd, 1950). 
Such a bract usually subtends a vegetative bud. Thls bud invariably remains dormant and wilts before the time of anthesis. On occasione a bract 1 a completely barren. Although they are usually at the base of the inflorescence, the lowermost bracts may arise sone alstance (up to $8 \mathrm{~mm}$ ) from 1t (PLATE 2, f1g. 3 infloresence at $\mathrm{right}$ ). They are usually ineerted so that they are decussate to the subtending leas and sten to which it is attached, but are sometimes inserted in the median plane of the subtending lear and stem.

(b) The terminal flower is often ebractate, with one or more bracts inserted on 1 ts pedicel or at the base of the floral receptacle. Rarely other flowers are ebractate, in the sense that they do not arise in the axil of a bract although a bract or bracts are often present on the pedicel or at the base of the receptacle. On occalons, in both genera, there appears to be a gradation between bracts and perianth parts with transitional appendages being inserted on the receptacle extemal to the perlanth parts.

(c) In Hedvearva the ultimate and penultimate pairs of flowers

- It is sometimes alfficult to judge precleely where the inflorescence axis ends and the pedicel of the terninal flower begins, In a nearly mature inflorescence. In PLATE 1, $11 \mathrm{~g} .2$, the terminal flower at flrat glance does not appear to arlse in the axi1 of a bract, for the bract scar is at "g". However 1t would appear from a difference in texture of the "atalk" above and below "s", that the pedicel does begin above "a". In other words, in this instance the inflorescence axis has extended appreclably beyond the level of Insertion of the ultimate pals of pedicels. In other Instances it would appear that the inflorescence axis does not grow appreclably above the level of insertion of the witimate pair of flowers. 
are frequently not separated by an internode, but the level of Insertion of the penultimate pair of flowers is alightly below that of the other palr (PLATB 2, IIg. 2).

(d) In Laurejia a lateral branch is formed when the vegetative bud in the axil of a leaf (PLATE 1, 1ig. 2) breaks dormancy. A lesf has elther a vegetative or an inflorescence bud in 1 ts axil but not both. It was observed in two herbariun specinena of L. serrata that when a lateral branch is formed, the firat pair of leaves are enaller than the others (PLATE 62). Whis feature vas occasionally found in $\mathrm{L}$. novae-zelandiae. As stated, the inflorescence axis may itself bear one or more bract: which subtend a vegetative bud, but this remains domant. In both Hedycarre arborea and H. Angustifolla some leaves bear both a young lateral branch and an inflorescence in their axils - the inflorescence being altuated closest to the petiole.

(e) A few aberrant inflorescences were found, noteworthy among which was that of a female ledvcarva plant with four palrs of decussately arranged flowers subtended by bracts which becane progressively larger and more leaf-like. The ultimate (5th) pair of bracts resembled minature toothed leaves and each subtended a vegetative bud and the axis terminated in an apical vegetative bud similar to that at the tip of a shoot. The axis had therefore undergone reversion from a 1 loral to a vegetative shoot.

(f) In soine Hedyearye inflorescences a pair of flowers or 


\section{Bodyeasys}

\section{(IIssar)}

There ware srom 3 tr 15 flowers per inflerescence. The Infloresconce with threo flowers had beon formed at the end of the flowering season. It comprised a lowermost patr of forthle bracts vith a storlie pair abovo and torminatod in a dingle 1lower which was subtended by a third pair of bracts. The commonest numbers of plowers per infloresconce was 7 , for both male and Ponale plents.

\section{ente}


secondary inflorescence axes are not inserted directly opposite one another (PLATE 2, 11 . 2).

(g) In a few mixed inflorescences of Laurella, the axis terminated in a pair of Rowers.

Hedrycarva - see insert at left

Laurelia

There were from 5 to 20 flowers per inflorescence. A diagran of a male inflorescence with 20 flowers is shown in PLATE 3, f1g. 4. The comonest number of flowers per inflorescence was 7 for male and 9 for mixed inflorescences. In the mixed Inflorescences, the main axis, and secondary axes where present, invarlably terminated in a male flower (PLTF 3, figa. 1-3, 5-7). The carpellate flower or 1lowers are usualy inserted lmediately below the terninal flower of the main or secondary axis (PLATE 3 , figs. 2, 3, 5-7). In one case however the alngle carpellate Plower was one of the penultimate palr ( $1 \mathrm{lg} \cdot 1)$. In another case one of the ultimate pair and one of the penultimate pair of rlowers were carpellate. The ratio of male : carpellate rlowers varied sonewhat but in general male flowere predominated. Out of 50 mixed inflorescences chosen at randon, $76 \%$ contalned predominantiy male flowers, 2\% had the same number of male and carpellate flowers and 22\% had predonlnantly carpellate flowers. Ratios varied from 8 male; 1 carpellate $(\mathrm{flg}, 1)$ and $1: 1$ (4 male and 4 carpellate) to 3 male: 14 carpellate (flg. 7). The commont ratio found in the New Plymouth material was 5 male : 4 carpellate (32\% of the 50 inflorescences). 
Conclusigng

The teranal vegetative aeristem of a shoot and the inforescence apical meristem are homologous in that they initiate in acropetal Buccession decusately arranged leaves (vegetative meriatem) or bracts (inflorescence meriaten) in the axils of which arise buda. These are inflorescence or vegetative buds (vegetative meristem) and Fower buds or secondary infloreacence buda (1uflorescence meristen). The two weristens differ in that the vegetative is indeteminate and theoretically unlibited in the number of leaves it can give rise to, whereas the infloreacence meristen (and any secondary inflorescence meristems it may produce) is deterinate. The inflorescence meristen is transformed into a floral meristem which grows into the terminal flower of the primary or secondary inflorescence axis. Although the order of intiation of the flower buds is acropetal, flowering begins at approxtmately the same time for all the member of an inflorescence. Flowers of an individual inflorescence open within one or two days of each other and a flower lin any position on the inflorescence may be the flrst to open.

These inflorescences would not come within the comnon usage of racemose which is usually defined in texts as an indeterainate inflorescence consiating of an axis bearing flowerg in acropetal succession. Nor could they be described as cymose which is generally defined as a determinate inforescence alsplaying sympodial growth "In which each succesive branch ends in a flower 
after bearing one or more bracteoles, from whose axils the branchIng is continued" (W1119, 1955). Thus "the plrst formed 11ower 1imita aplcal growth of the main axis of the inflorescence" (Fames, 1961).

The infloreacences resemble the racemose type in being basically monopodial and the cymose type in being determinate. Secondary inflorescence axes when they do not resemble the main axis, appear to be of the monochasial or dichaslal type. The resemblance to these types 1 s strengthened in that the terninal flower ir often ahead of the other flower or flowers in ita development, for a time (see monochaslua at lower left in PLATE 2, f1g. 2).

Fames (1961) has criticised as "unsatisfactory" and "morphologically Inaccurate" the way in which the order of development of flowers is used to distinguish the major types of inflorescences. He noted that many inforescences are intermediate in type, with racemose forms whlch have a terminal flower and aded that a eingle genue may have both determinate and indeterwinate inflorescences. Carlquist (1961) has praised the work of Rlokett (1955) in delimiting and rederining inflorescences. According to this clasalfication the inflorescences of Laurelis and Hedycerva would be of the racemose type. After an historical survey of various definitions in which he pointed out inconsistencies in their application to actual inflorescences, Rlckett concluded that the important distinction between remose and cymose inflorescences 

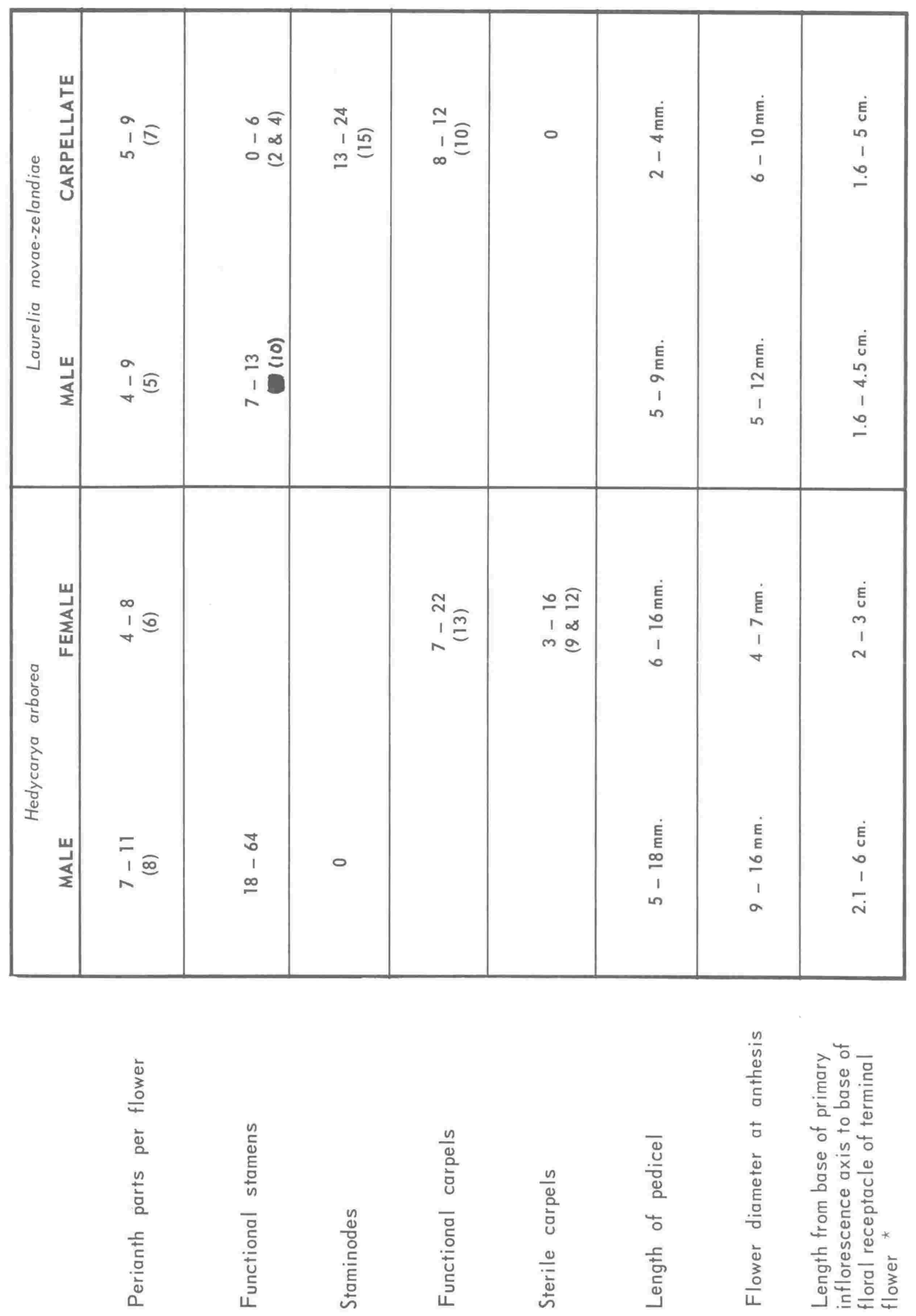

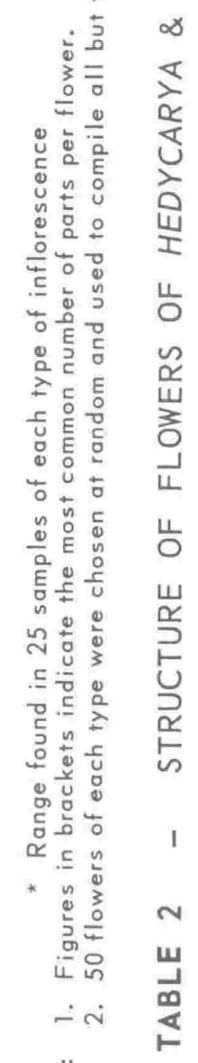

崩 
was whether they were monopodial or sympodal. I would concur with these views and 1 can be seen that liedycarya and Laurelifa would conforn to Rlckett's definition of racemose as - a monopodial Inflorescence composed of a central axis along the sides of which axise pedicellate flowerg or mall flower-cluster, ueually arising in the axila of bracts; flowering is conmonly but not necessarily acropetal, and the axis may or may not be terninated by a llower.

Inlorescences of other member: of the family will be discused later in the chapter. Structure of the glowers

Floral structure is sumnarized in Table 2. The carpellate Laurelia flowers are readily distinguished from the males even in bud stage becaure they are perigynous with an urceolate receptacle, whereas the male flowers are hypogynous* (PLATE 1, fig. 2; PLATE 2, f1g. 1). Wale and female Ledycarys flowers can also be distinguished from an early atage in development. The femele flowers (PLATE 4, fig. 2)

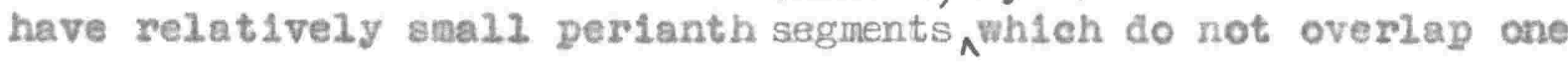
another much in the bud. The male perlanth parta are larger and not as tapered. They overlap conelderably in the bud atage and the nale flower has a concave receptacle with the tips of the tepals curving downwards into the central coneavity (PLATE 2, IIg. 2) In marked contrast to the female flover. The inflorescences differ in that the male ones axe more erect.

- This is also true for Atherosperma, but a palr of bracts enclose each flower bud and mask these features. 
In both genera the perianth parts are not differentlated Into sepals and petals. These tepalm are larger than the bracts, but as stated intermedlate forms are often found. Bracts and tepals are rather sinilar in coloux and texture except that the tepals are less pubescent on thelr 1nner (adaxial) surfaces, which are a lighter shade of green or greenish-white (IATE 5. fig. 1; frontisplece). The tepals persiat into the fult stage and can be seen (" $t$ ") on mature pseudocarps of Laurel1a (PLATE 6, fig. 1) and below fruits of Hedycarya (19. 2).

In Laurelia the two outermost tepals are usually opposite each other and decusate to the subtending bract and inflorescence ax1s. The remaining tepals are arranged in a spiral of about 1 turns. In some flowers all of the tepals are arranged in two whorls. In the bud stage part of each tepal overlaps part of the adjacent one (imbricate aestivation), apart from the two outer tepals where the tip of one tepel may overlap the tip of the other.

In Hedrcarya the outermost four tepals are arranged in decussate fashion although one of the inner pair may not be exactly opposite to ite partner. The remaining tepals are arranged in a whorl. In some cases only the outermoat pair of tepels are inserted outside the others and the latter are in a whorl. At naturity the tepals usually appear to be in a single whor I (PLATE 5, 11g. 2). Some Plowerg have one or more reduced tepals inside the others, arranged in a second whorl (PLATs 5. Ig. 3, "p"). 
The female flowerg of Hedycarva comonly have fewer tepala than the males in contrast to Laurelis (Table 2). In Hedxcarya too, the fenale flowerg are of maller dianeter\% (Table 2). In Iaurelis the male and carpellate lowers are of elmilar dianeter but as shown in the Table the carpeliste flowers have shorter pedicels. The pedicels of male flowers are equal to the corblned length of the pedicels of carpellate flowerg and the urceolate receptacle. This seems to be slight evidence for regarding the urceolate receptacles of carpeliate rowers as axial in nature (see on).

The stamens of Hedvearya are arranged without great prec1sion along a siral of approxinately $3-4$ turne. The outermost carpels In the fernale flower are sterile and reduced in Blze and structure (e.g. "c" in IJATE 12, fig. 3). They occupy a single whorl or sometimes two whorle. They are solid structures without a 1ocule. Sone carpels were found internal to these, in sone flowers, with a structure sonewhat Internediate between the sterile and fertile carpels. They possessed an ovule but this was reduced in size. One auch ovule had reached the megaspore mother cell stage but ald not develop further. Internally the fert1le carpels are arranged along a spiral of about 3 turno.

The stamens in the nale $n$ ower of Laurelin are arranged in a Bpiral of 2-3 turns (PLATE 5, flg. 4). The stamens (where present) followed by staminodes in the carpellate flower are Measured from petal-tip to petal-tip when the flower is fully
open. 
arranged in a spiral of about 3 turns (PLATE 5, flg. 5). It aeens surprising that the carpellate flower should contain a greater total number of stamens and staralnodes, than the asle Plower does of atamens (Table 2). The carpels are arranged in a apiral of approximately 1 tums. A single teratological flower was found in which functional stamens and staminodes were preaent as in a carpellate flower but the flower lacked carpels. Veacularisation of florad parts

Laurel1a:- bracts and tepals

No signifleant differences were found in the vaseulature of bracts subtending male flowers on the one hand and carpeliate Plowers on the other: nor between tepal of male and carpellate Plowers; nor between functional stamens of male and carpella te fowers. The bracts (PLATE 7, figs. 9 \& 10) have a more complex vascular supply than the tepals (figs. 1-8). Each bract has a number of Ine central strands which do not branch and a number of Iateral traces, more ( $19 \mathrm{~g}$.9) or less ( $1 \mathrm{gg}$. 10) adjolning the central strand.. The lateral traces are branched and in some bracts $(11 \mathrm{~g} .10)$ they anastomose.

The vascularization of tepals varied considerably. For example flgs. 3-8 11lustrate the vasculation of 6 tepale from a

- It should be noted that in this and other lllustrations only the trecheary elements of the xylem are 112 ustrated. The techniques ueed ald not render vislble other elements of the vascular bundles. Thus in fig. 9 for exanple, what appears to be a number of Pine central vascular strands is in fact just the water conducting elements of the xylem and each strand $1 \mathrm{~s}$ one or more tracheary cells in width. 
single carpellate flower. No two of these have the sane vascularization. There were two basle patterns; (a) a single median trace (Plgs, 1, 6) or group of traces, with lateral branches; or (b) a single median trace or traces, with lateral. branches, plus a lateral trace which may or may not branch, on elther side of the medion trace (figs. 2-5, 7, 8). An unusual feature of tepal vascularization was the presence of 1solated vascular otrands near the periphery of the tepal. They were present in all tepals examined. Flgs 1 and 2 of PLATF 8 are photonicrographs of an isolated vascular strand found within the dotted portion of fig. 1, PLATE 7. Kasapligil found on occasione one or two isolated traces within the sepals and petals of Umbellularia. He concluded that they might posalbly represent a reduction series from a three-trace to a one-trace condition in the sepala and petals (see IIgs. 14-22 of his paper). He did not find isolated traces near the margins of the perianth parts analagous to those in Laurella. I, 11ke Kaeaplig11, did not make a detalled study of the isolated atrands to determine whether they were connected to other stranda via undifferentlated procambium. Such a stuay would be time-consuming a procambium is not visible in clearings and one would have to make a threedimensional reconstruction from aerlal sections. I would suggest that tepals have been derived from bracts in Laurelia and that the 1solated strands repregent traces which have been partly lost during the derivation of the tepals from the more extensively 
vascularized bracts. Kasaplig1l noted that 1solated traces have been found in floral organs of a number of dicotyledong. I have not been able to find in the I1terature other examples of 1solated peripheral traces in perianth parts.

Hedycarya:- bracts and tepals

No differences were found in the vasculature of brects of male infloresences on the one hand and female on the other. The larger bracts (PLATE 7, flg. 19) had a median group of unbranched traces and two lateral branched traces. This basic pattern of central unbranched traces and lateral branched ones 1a similar to that found in Laurelia, but simpler. No anastomosing traces were seen. Smaller bracts had a more reduced vasculation (figs. 20, 21) with reduction to a single median strand and the smallest bracts were not vascularized.

The tepals too were less complex in their vascularization then in Laurelia. The smaller size of tepals of fenale rlowers wes reflected in thelr sitngler vasculariation. Figures 11-18 11.lustrate tepals of female flowers and flgs. 14-18 are from a single flower. Most tepals had a single unbranched median strand (11gs. 11, 16-18) thereby resembling small bracts. Sone contained a pair of strands; one on either olde of the mid-ine (11g. 13); others a median and a lateral strand (fig. 12). Sometimes the median strand branched (Plgs. 12, 14, 15). In some casea 1t seems clear from the size (larger), shape (notched apex) and venation (more traces) of a tepal that it has been formed 
from the coalescing of two tepol primordia. The tepals of the male flowers are larger and ugually have more velns than those of the female flower. They have $2-5$ traces (most commonly 3) whlch may or may not branch (PIATE 5, flg. 2; PLATE 11). Laurs 12a:- stamens and staminodes

There 15 considerable varlation in stamen vascularization (PIATE 9, 11gs, 1-10). Gtamens 11lustrated in P1gs. 3-7 were from a single mele flower, yet no two have an ldentical vasculation. The ear-like, stalked, vascularized staminal appendages of Laurelia and some other genere in the famlly, which are inserted two per atamen on the fllament, have been termed "stam1nodes" by Money et al., (1950). In Laurelia and in some of the Lauraceae at least, the appendages function as nectaries (Bee Chapter 5). To avold confusion with the sterile stamens (1.e. staminodes) of the carpellate flower and in order to use a non-committal tera, I shall follow Kasaplig1l and call the appendages dtarinal glands in Leurelig. Isolated traces were found in some stamens near the base of the stamen (ILg8. 3 and 10). Isolated strands were found too in some staminodes ( 1 gg. 12 and 14) but situated at a higher level. Rasaplig1l found laolated strands in some stamens and ataminodes of Umbelluzaria and Laurus. They were not completely analagous to those in Laurelis. In Umbellularia an 1 solated strand was only found $1 \mathrm{n}$ some of the case in which one or two of the four pollen ace had aborted. A vascular tisaue was developed in place of the ster11ized pollen sacs and 
this tiesue may or may not be connected to another trace. In the stamens of Lauxus the 1solated strands occur whenever a etaranal gland $1 \mathrm{~s}$ reduced in $51 \mathrm{z}$ and 1 ts vacculation appears as an 1 solated t1ssue. Kasaplig1l (1951) found thot undifferentiated procamblum did connect the xyzem of such a staminal gland to a lateral vascular trace of the fllament. He did not state whether this waะ 1nvariably so.

Two basic vacularization pattems were found in stamens of Laurelig:- (a) There is a central strand (or strands) without lateral branches which pasees through the connective and terminates near the tip of the stamen. The strand may or may not bifurcate near 1ts tip (compare figs. 1 and 2 of PLATE 9). Where there are two or nore central strands, these fuse for some of their length (tigs. 4, 5, 7, 9, 10) and usurily separate near the t1p of the stanen and may then bifurcate (e.g. Ilg. 5, trace at right). Kasapligil too, found that the centrel vasoular tisoue in Umbeliularla stamene consisted of a slngle thlck trace or a number of thinner traces and made the 10 geal conclusion that the single thick trace has resulted from the fusion of thinner traces. Where there is a single lateral trace to a gland, it usualyy divides before entering 1t (11gs. 1 and 2 - trace to gland at right). Where there 1s more than one lateral trace to a gland, these traces may ( 1 Ig. 1 , trace to gland at left) or may not, fuse $(118 \cdot 7)$.

(b) One or both ataminal glands may be vascularized by a lateral 
branch from the central strand (f1g. 6, trace to gland at left) or group of strands (1). 3, trace to gland at right). Pigure 25 of Money et al's paper shows a stawen of Jaurelis in which both glands are vaecularized by lateral branches of a central strand. In thls 1llustration the extent of prolongation of the connect1ve beyond the anthere has been exaggerated.

Varlations within the two basic types were as rollows:-

(1) In some cases a strand enters the base of the fllament but soon terminates (IIGB. 7,9 ). Such a strand sometines originates as a branch of the central strand ( $11 g \cdot 6)$.

(11) In a number of stamens, a strand passes towarde the bottom or pollen sac and terminates at varying ditances from it. Such a strand may elther be a discrete lateral one (figs. 2, 4) or It may orlginate as a branch from a strand to a gland ( $1 \mathrm{gg}$. 9, 10 - trace to gland at right).

(111) Frequently a glandular trace extends into the f1lament to a level beyond the level of Insertion of the gland and then bends downwara abruptly and passes into the gland (e.g. 12g. 3). A glandular trace may bend sharply even when it does not extend above the level of insertion of the gland (figs. 8, 10). This type of trace has not been described for stamens of Laurus or Umbeliularia. It presents a problem in interpretation. The coneervatiam of vascular traces has been established in some cases e.g. In Eames' (1931) clasalc study of the lnferior ovary in the Brieales. If the bent strinds in lawrelia represented a 
conservative condition, thid might indicate that the glands were once inserted at a higher level.

F1gures 16 and 17 111ustrate the vasularization within the stamiral glands. Sometimes one but in general two, etrands enter the gland and each strand dividee a number of times, usually aichotomousiy, to produce a somevhat dendritic vascular pattern. Similar but more extensive vasculation occurs in Laurug and Umbel2ularia (Kasap11g11, 1951). An unusual feature in Laurug, not found in the other genera, was that the glands of the gtaminodes of carpellate flowers had a more abundant vascular supply than did those of stamens.

F1gure 11 11lustrates a transitional atage between a stamen and staminode. Thls particular organ underwent dehiscence but contained abortive pollen. Its reduced staminal glands were not vascularized. In this situation therefore the hypothesis of conservatism of vascular strande would not apply. The reduced gland shown in $11 \mathrm{~g} \cdot 12$ is however vascularized. Applying the hypothesis of conservatian again, it could be argued that the two lateral traces of the staminode 11 lastrated in $\mathrm{Pig} .13$ represent traces to formerly existent glands. However they reach rather a high level in the stank node: higher than one would normaliy find glands, although it should be recalled that glandular traces in Bome stamens bend dowmwards. On the other hand the traces may represent a pair of lateral traces analogous to those terminating near the bases of pollen secs in some functional stamens. The 
simplest etaminode which I examined, 18 1Ilustrated in 1 ig. 15. In no Inetance was a etaminode found with a single unbranched median trace thereby differing from the simplest ones in Umbel2ularla (Rasap11g11, 1951). In contragt to the stamens, no staminodes of Laure 19 were found in which a median strand or strands bifurcated near the tip of the organ.

Kasaplig11 concluded on evidence from vascular anatomy and from transition forms, that the staminode of Umbellularie represents only the fllament portion of modifled stamens. This does not appear to be true for Laurel18. It would seem that the alstal part from where the staninod broadens, has been derived fron the anther portion of the functional stamen.

A comparigon of PLATE 7, 11gs, 1-8 and PLATE 9, f1gs. 1-10, reveals that some stasene resemble many tepals in having a median strand or group of strands and a lateral strand (or group of strands) on each slde of the ald-veln. Hedrearra:- stamens

Each stamen 18 vaseularized by a median strand or group of aggregated strands whlch pass through the connect1ve. The vascular t1ssue terminates at the level of the alstal tip of the polien sacs and does not extend into the prolongised part of the connective beyond the pollen eacs. Some atamens are vascularized by two strands or two grougs of strands which may (PLATE 11, "a") or may not ("b") originate from independent parts of the vascular system of the torus. In PLATE 12, 19.1 , two strands can be 
seen at the procamblal stage entering a young stanen from d1fferent alrections. The two strands aggregated near the centre of the stamen (not shown in the section 11lustrated). As can be seen In the section, the strand has bifurcated near its tip. Lauredia:- carpels

There Is 11ttle pluctuation in detalls of carpel vascularization. A single dorsal and a single ventral trace enter each carpel. These two traces may or may not both come from a single trace in the torus. The ventral (adaxial) trace 1 o short and unbranched and passes through the ventral wall of the carpel unt1l it reachee the funicle of the single anatropous ovule. It enters the funicle and terminates in the chalazal region of the ovule (PLATE 10, P1g8. 8, 9). The thicker doral (abaxial) trace passes through the doral wall of the carpel where 1t blfurcates tw1ce. The strande terminate a short alstance below the stignatic region of the carpel - which commences above "s-t" in I1gs. 8 and 9. Money et al., In $12 \mathrm{~g} .38$ of their paper, 11lustrated a carpel of Laurelia sempervirens. Its vascularization resmbles that of L. novae-zelandige except that the dorsal trace does not branch. Hedycarya:- carpels

These show some variation in vascularization. There is a ventral trace or aggregated traces and a dorsel trace or aggregated traces. In contrast to Laurelia, the doral trace or traces pass Into the stigmatic region (above "s-t" In PLATE 10, fig. 2) where there 1s profuse branching. Two main types of vascularization 
were noted:-

(1) A single unbranched ventral trace passes through the ventral wall of the carpel, enters the ovule via the funicle and teminates in the chalazal region (fig. 6). It therefore reambles the condition in Laurelia, sthough the ovale of Hedrearva has 1 ts mieropyle directed upwarda.

(11) Before entering the ovule, the ventral tracer forms one (IIgB. 1, 2, 4) or two (11gs, 3, 5) laterel branches. These may or may not ( $\mathrm{Sg} \cdot 1$ ) extend through the ventral wall of the carpel to a level above that of the ovalar trace. In some carpels one or both of the lateral branches fuse with the dorsal trace syster in the etigmatic region. The carpel show in fig. 3 11lustrates this condition. It is arawn as seen from the adaxlal side and the two lateral traces ean be seen on elther side of the median ovular trace ("o"). In $21 \mathrm{~g} .2$ it can be seen that the lateral branch of the ventral trace has split into a number of anall branches at $1 \mathrm{ts}$ tip. In one carpel the ventral strand split into two lateral traces and a median ovular trace. The ovule trace, juat before it pasaed into the funicle of the ovule gave off a amall branch which passed upwards through the ventral wall of the carpel for a short distance.

As shown in figs. 1-6, there is variation in the complexity and extent of ramiscation of the dorsal strand. In many instances a branch from the dorsal complex extends dowawards through the ventral side of the cargel wall towards one of the two lateral 
branches of the ventral strand, as with "d" in $11 g .3$. In many cerpelis one or a pair of upwardiy extending ventral atrands do not quite reach one or a pair of downardiy extending dorsal strands. In fig. 1 a branch of the dorsel strand extends towards the short lateral ventral strand and another branch of the dorsal strand extends downards towards the position where the second lateral ventral branch would be, if it were preaent. It would seem likely therefore that the ventral trace syatem has become reduced and wholly or partially detached fron the dorsal aystem during the phylogenetlo development of the carpel.

Money et al., in $\mathrm{flg}$. 34 of their paper lllustrate a carpel of Hedycseys derstenloides in which both the laterel branches of the ventral strand have fused with branches of the dorsal strand. This occurs infrequently in $\underline{H}$ arboree.

The carpels of Laurus and Umbelluiaria have a aingle anatropous ovule with the micropyle pointed upwards as in Hedycarye and are in general vascularized by a dorsal and a ventral (ovular) trace (Kraplig11, 1951). Aa in Hedycarya this dorsal trace terminates near the $t i p$ of the earpel. It may or may not branch dichotomousIy near ite tip. Such branchea when present are less extensive than in Hedvarys. Some teratological carpels of Umbellularia have supomumerary traces. In some of these carpels one or wore of the traces is isolated, although connected to other traces by means of undfferentiated procambium. The ventral trace is unbranched within the carpel wall and in contrast to Hedrearya 
and Laure 1a, 18 grofusely branched at 1ta tip, within the ovule. origln of vascular strends to $120 \mathrm{xal}$ anpendeges

The rather complicated and varied vasculature of the 17oral receptacles was not studied in great detail. Wost attention was given to the male flowers of Hedycarys arborea, to peralt comparison with felville's (1963) study of the vasculature of the male flower of Hedycarva angustifolia.

Plate 11 1llustrates part of the vasculature of the male flower of Hedvearye arborea. For singliclty the vascular supply to the basea of stamens deplcted by broken 11nes, rather than by aotted lines, 2s omitted. The following features can be seen in the PLATE:-

(a) The tepala may ("P") or may not ("Q") be vascularized by strands which orlginate from a single strand in the torus. (b) As already stated, each stamen may or may not bo vascularized by etranda from 1ndependent parts of the torus. one stamens (e.g. "GI" in PLATE 11) are vasculamized by a aingle trace from the torus.

(c) In figener, each stamen 1 vasoularized by a strand or strands which originate from a strand or strands which also suply the tepals. An exception is the vascular supply to the atamen labelled "g".

The vasculature of the other flowers does not differ greatly from that described above. In female Hedvearve flowera each sterile carpel has a single trace which may originate from a atrand 
supplying a tepal or bract. Tach fertile carpel is vasularized by dorsal and ventral strands which may or may not arise from independent parts of the torus. In male Laurelia flowers too, the traces to each stamen may or may not originate from independent traces in the toxus, and may or may not originate from a strand supplying a tepal. In carpellate nowers the dorsal and ventral traces of each carpel may origlnate from the same or different traces in the torus.

If PLATE 11 is compared with $1 \mathrm{lg} .56$ of Velville's paper, which 1llustrates the male flower of Hedycarya angustifolig, the following differences emerge:-

(1) Although the vein pattern within the tepals is similar in both species, the vascular supply to each tepal of $\mathrm{H}$. angust1folis originates from a single strand in the torus.

(11) In $\mathrm{E}$. angustifolle there is only a single trace to each stamen which invariably originates from a trace supplying a tepal.

Such differences seem surprlelng within a eingle genus, eapecially as the flowers of the two species seemed of a similar morphology, including the presence of sterile outermost carpels In female $\mathrm{H}$ - angustifolig flowers. I therefore decided to clear and exanine thale Plowers of $\underline{H}$. angustifolla which I had collected in New South Waleg in order to check lelville's results. I Pound, as Melville indicated, that the vascular supply to each tepal originated from a single strand. Most stamens were vascularized by a single trace or group of traces which originated. 
from a single trace to a tepal. However a few stamens were each supplied by two groups of traces originating from different vascular atrands in the torus, as in many etamens of $\mathrm{H}$. arborea.

1 found in cleared carpels of $\mathrm{H}$ - anguatlfolda that the dorsal trace passed into the stignetic reglon and branched as in 1 . arborea, except that there were no branches from thas complex which extended downward on the ventral wide of the carpel. No ventral ovular trace could be seen within the carpela despite the fact that they had been removed from 1 lowers which had reeently undergone anthegis. Haterial was therefore sectioned at this stage and it was found that the ventral trace was present but the celis of the trace were still at the procambial sta e. No supraovular traces were observed, in contrast to y. arborea. In young eleared frults of $\mathrm{H}$ - angustifolda the ventral ovular (seed) trace could be cleasly seen but although 30 frutis from three llowers were exanined, no supraovular traces were found. There have been records of other plants in which the ventral corpellary trace or iraces mature after the dorsal one(s); for example in Hchelia of the Magnoliaceae (Tucker, 1961); in Drinve lancerlete (Tucker and Gifford, 1964) and in lactorts (Carlquiat, 1964). I also found this feature in arpels from cleared flowers of Doryphora sassafras and Atherosperma moschata. In these genera the ovular trace was not vieible at anthesie but was visible in young cleared fruits of Atherosperma. No fruita of Dorwohorg

* Obtained from Mt. Wilson, Blue Mountains N.S.W. through the courtesy of $\mathrm{H}$. J. Waterhouse, Botany Department, University of New South Wles. 
were available for me to investigate.

Nelville (1963) stated that in the male flower of Hedycarya the basal halves of the petals are fused, with the stamens being attached to the upper eurface of this fused part. This is a difficult statement to prove or disprove. In the ontogenetic development of the male flowers of the two species under consideration ( $\mathrm{H} \cdot$ arbores and $\mathrm{H}$ - angustifol1a) the tepal and stamen primordis appear as independent protuberances from a concave and slattened floral apex (PLATE 27, fig. 11). The eltuation was not encountered in which the stamens are infitated as protuberances on the edaxisl surface of a hollow cylinater, with the latter clearly representing the phylogeneticaliy fused beses of the tepals. The problein therefore hinges on whether the concave floral apex Is In fact a somewhat aunken receptacle (axial theory) or whether 1ts more distal part consists of the fused bases of the tepals and stamens (appondicular theory). The vaseular anatomy of the Plowers seeme to neither prove nor deprove elther theory. Although I pavour the axial theory in this case, I tart conclude that until a thorough comparative ontogenetic study 1 s made of the flowers of other epecies of Hedvcarva and related genera, the problem remains open. HeLean and Ivimey-Cook (1956) have described and 11lustrated the male and fenale flowers of Tambourisga which Money et al., place in the mame subfamily as Hedycarya. In Tambourlass the flowers of both sexes are cup shoped and the carpels are actually sunken into the inner surface of the "cup". Helean 
and Ivimey-Cook concluded that this cup in Iambourisse "does not bear the aspect of a combination of orgens, but rather that of a genuine receptacuzar cupuze".

This brings us to a consideration of the nature of the urceolate hypanthiuno of the perigynous carpellate flower of yaurelia. lias the perigynous cup formed by adnation of tepale to otamen and ataminode bases or has it forned in an axial manner by the invagination of the receptacle? Esmes (1961) has pointed out that there have been only a fev cases in which the eup has been formed by sinking of the receptacie s.g. In Cactaceae. However It is tempting to concluce that the hypanthitu is Leureila has formed in this manner, lor the following reasons whlch are in adition to the slight evidence given on page 23.

(1) There is a ring of vascular bundes in the hypanthiut, as in the pedicel. There 18 no fucson of tepal and staken or staminodal traces within the hypanthim such as oceurs in some nembers of the ricaceac where there has been adnation of appendages (Hames, 1931). Ary fusion of traces from different appendages occurs at the tip of the hypanthium. (11) If the region above the hypenthin is considered, the tepals and functional starene are of similar size and shepe to thoee in the tule sower, in which no hypanthium is present.

Nonetinelese this problem too should reasin open unt11 a thorough atudy is wade of related flowers in the fanily.

\footnotetext{
1t This term is used according to Eames' (1961) definition of
it $(\mathrm{p} \cdot 249)$.
} 
Discusston

The inflorescences.

Perkine and $01 \mathrm{lg}$ (1901) 1llustrated four inflorescences of Laurel1a sempervirens. Each consists of two palrs of decussately arranged flowers. The absence of a solitary terninal flower seems surprising in view of 1 ts almost invariable presence in L. novae-zelandiae. I have not been able to obtain flowering material of L. Bempervirens to check Perkins' and Gilg's obserm vations. However their 11lustrations of plants known to the are of a high order of accuracy.

There is considerable diversity in infloresences within the fan1ly. They vary from the enormous number of plowers in the decussate - paniculate inflorescences of Klbara (Perkins and O1lg, 1901): to the dichaslal cymes of varying complexity in Macropeplus (1b1a): to the type in Hedvcampa and Laurel18. The simpleat are the three-flowered cymes of Dorvphora and the single-flowered inflorescences of Atherosperma (PLATE 13, figs. 1, 2). Ephlppiandra of the aubfanly Monimioldeae also has solltary flowers in the leaf axils (Perkins and G1lg, 1901).

From descriptions of genera in the family in Perkins and G1Ig (1901) and Perkins (1911) I would conclude that the basic type of inflorescence has a decusate phyllotaxy, homologous to that of the leaves. Cymose inflorescences woula seem to be derived from this type by reduction, with intermediate forms being present in a number of plants including the $\mathbb{N} \cdot 2$. species of Fedy- 
carva anc Laurelia. It seems clear that solitary flowers of some plants in which the flowers teminate a shoot may represent a primitive condition, as in Magnolia and Lupomatis (Eares, 1961; McLean and Ivimey-Cook, 1956). However in the words of liames "Solitary axillary flowers are commonly surviving units of axillary clusters". This latter would seem to apply to AthereBpexag. Its solitary flower could have been derived from the three-flowered dichasial eyme of the related Doryborg by suppression of the pair of flowers. It could be argued on the basla of an ebractate peduncle up to $1 \mathrm{~cm}$. long in Dorwphora that this proximal sterile part of the inflorescence has ariaen by suppresalon of flowers, presumably with a decussate phyllotaxy. In this genus the opposite pair of flowers are bractate and the pedicel of the terminal flower arises in a pair of caducous bracts. Now In Atherosperma the rlower is subtended by a pair of bracts which are inserted at the distal end of the flower stalk, in such a way as to resemble sepals ("br" in PLAT 13, f1g. 2). If each of these bracts once subtended a pedicel in the ancestor of the pregent day Atherosperma, (as in Doryohorg), and such a pedicel has been suppressed, then the flower stalik of Atherosperma would be morphologleally a peduncle.

The mixed inflorescence of Laurelia novae-zelandige is an unusual type. I can find no reference to other plants with mixea inflorescences in which male flowers are followed by carpellate ones, followed by a teminal distal male flower. A few other 
genera in the Honlmiaceae have mixed inflorescences e.g. sone species of Slparuna (Perk1ns and G11g, 1901; Perkins, 1911), but these are not comparable. I have no information as to whether mixed inflorescences occur in the other two specles of Laurelia. Presunably after the ale flowers have been inftiated in L. novae-zelandise, including the terminal flower, there is an internal chemical change which leads to the production of the sub-terminal female flower(s). At present little is known of the phyelological ractors governing aex expreasion in plants. Experinents in some monoeclous plants in the Cucurbltaceae have shown that the proportion of female rlowers in a mixed 1nflorescence can be increased by spraying the plants with certain cuxins (Heslop-Harrison, 1957, 1959).

\section{The flowers}

There are transitions between bisexual and unisexul flowers in the family (Money et al.). The lnternediate stages, e.s. in those carpellate flowers of Laurelie and Atherosperna which have one or more functional stamens, indicate that unlaexuality is a derived condition. It 18 of interest that all genera with bisexual flowers in the subfamily Atherospernoldeae - Daphnandra, Doryphore (PLATE 13, PIg. 3), Dryadodaphne and Neunaron, have staminoded. They are analagous to the staminodea in the carpellate flowers of the remalning genera - Atherogersma and Laure12a. The most perfect bl sexual flowerg occur in Hortonis angustifolis and H. Lloxibunda of the subfamily Hortonloideae, which uaue11y lack 
any staminodes (Money et a..). The Plowere of the aubfandy Monlinotdea, which includes Hedverrys, are invariably unisexual and the flowers of each sex lack any rudiments of the other sex, except in the female rlowers of Eeunue which bean three-lobed staminodes (Money et al.).

Pexianth. In Trigenta* of the Trimentaceae, a fanily closely related to the Moniriaceas, the imature stamens and carpel are 1nveated by 5-25 palrs of decussately arranged scale11ke appendages. They are declduous prior to anthesis and leave the stamens ard carpel devola of a perianth (Money et 2.1.). The lowernost palrs of appendages differed from the upperinost ones in shape and foney et al., concluded that there was an intergradation between bracteoles and tepals but that there were no morphological boundaries between then. It such a 1 ower $1 \mathrm{~s}$ primitively aimple then it would appear to 1llustrate a stage in tho derivation of tepals from bracteoles, whlch themselves represent modried leaves (Eames, 1961). It has been noted that In Hedycarwa and Laurel1a occaslonal appendages occur which are intermedate in structure between bracts and tepals.

Woney et al., stated that the tepals in the famliy have a fundamentally decussate arrangement with transitions to cyclic. I have mentioned a further trend to $\mathrm{sp} 2 \mathrm{ra} 21 \mathrm{y}$ arranged tepals in some llowers of Jaumelis.

An advanced feature of the perianth in Bome genera is in Ita

- Perkins and Gilg included this genus in the Monimiaceae. 
differentiation into sepals and petala e.g. in Daphnanare. Another advanced Peature in some genera is the presence of a constant number of perianth parts per rlower. For examle Doryohorg has 6 tepals per flower (FLATH 13, fig. 3).

Berianth vascularization. It has already been noted that the vascularization of the tepale in Hedvcarva and Laurelia seems to be derlved from that of the bracts by reduction. Assuming that such bracts have been derived from leaves, or at least had a comon anceator with the leaves, 1t seeme surprising that they do not show a close reserblance to the leaves in thelr venstion. The leaves in the fanily axe typicaliy dicotyledonous with a thick ata-veIn and pinnately arranged lateral veins. The ae laterala in Laurelia, Hedvearva and Atherosperma at least, give of branchos which form a reticulate venation with sone of the veiniets having spee endings. I declded to examine cleared bracts and tepals of Dorycohora and Atherogpexpa to detemane whether they showed a closer resemblanee to leaves in their vasculature. The following results were obtained:(a) The most prifitive type of bract venation oceurs in Atheroaperna". There is a mid-veln and pimately arranged laterals. Branches of the laterals form a network which is less extensive than that of the leaves. Some of the velniets have free endings. It would appear that the type of bract venation in Laurelia arose when the larger, lower lateral veins becume disconnected from the 
ma-veln during evolution of the bract.

(b) The nost primitive type of tepal venation was found in Doryphom: There is a mid-vein and lateral veins are inserted in pinnate fashion on the dietal two-thirde of the mid-vein. The laterals usually branch dichotomously one, two or three times. In some tepala a few of the lateral velnlets anastomose but not extenelvely enough to form a network. In addition there are one or two dichotomously branched lateral veins on each alde of the mid-vels, which are free from the mid-vein. They varcularize the lower part of the tepal. Bracts of Dorvphora have a almilar venation. There $1 \mathrm{~g}$ then in this genus, in the tepals and bracts, an intermediate stage in the derivation of a palmate-parallel vascularizatlon system from a plinate one. Balley (1956) noted that venation of perianth parts "tends in many cases to be pseudopalmate even where the leaves have a typleal pinnate venat $10 n^{\prime \prime}$. The tepal venation of Atherosperma (PLATE 13, f1ga. 1, 2) resembles that described for the male 2 Lwers of Hedvearya.

The above resultw support Hlepkb's (1965a and b) conclusion that the perlanth parts of the woody Ranales are bracteold in nature, at least for the Monfmiaceae. In contrast to this, some members of the herbaceous Ranales are considered to have petals which have been derived from stamens by aterilization, e.g. some of the Nymphaeacere (H1epic, 1965; Moseley, 1958).

- This ia argued on the aseumption that the most primstre type of venation is that which most closely reserables the leaf venation. 
Staminal appendages and valvolar dehiscence. The stamen of Hedycarya with 1t: four decurrent pollen sacs which dehisce by two longltudinal slita, 1to simple vascularization and lack of a filament, contrats markedy with the stamen of Laure $1 \mathrm{ag}$ with 1ts two pollen sacs, valvular dehiscence, varied vascularization and short fllament. The stamens of Laurelia more closely reBemble those of Umbellularia and Laurus of the Lauraceas. There is however a 11nk between the stamens of Laurel1a and Hedvcarya In that the stamens of Peumus and Moninis of the aubfan11y Monsmioldeae to which Hedvearya belongs, posess staminal appendages (Honey et al.). Such stanens resemble those of Hedycarra In having longltudinal anther dehiscence and from 11lustrations In toney et al's paper and in Perkins and ailg (1901) it seems I1kely there are also four pollen sacs per stamen. Money et al., stated that flowers of the Monimioldeae (except Reunus and Moninla) and the Siparuneae "have lost all vestiges" of the palred staminal appendages. They presumably therefore consider these plants once had the appendages and therefore the presence of appendages on the stamens represents the more primitive condition in the family. The occurrence of palred staminal appendages and valvular anther dehlscence in the Laurales (sensu Kutchinson, 1959) can be sumar1zed as rollows:-

* Compiled from information and illustrations in Money et al., (1950); Perising and G11g (1901) and Hutchinson (1959, 1954). 
MONIUIACSAE

$$
\begin{aligned}
& \text { Hortonloldeae - ataminal appendages; longltudinal-slit } \\
& \text { Honimloldeae - staminal appendages in Konimia and Peumus } \\
& \text { only: long1tudinal slit dehiscence; } \\
& \text { probably four pollen sace in all genera. } \\
& \text { Atheroapermoldeae - staminal appendages; valvular dehlscence; }
\end{aligned}
$$

LA URA CEAE

Staminal appendages; valvular dehlscence; two or four pollen sacs.

GOMORTECACEAE

Staminal appendages; valvular dehiscence; probably two pollen sacs.

HERNANDIACEAE

Staminal appendages; valvular dehiscence: probably two pollen sacs.

There $1 \mathrm{~s}$ thus in the Laurales a widespread occurrence of stenlnal appendages and valvular dehiscence, but the two charactere do not always occur together. Velvular dehiscence also occurs in the Berberldaceae and in sone of the Hamamelidaceae. Hutchinson (1964) concluded that this character in the Berberidaceae did not signify a cloee relationshlp to the Laurales, "probably being nothing more than parallelism". As the Hamanelidaceae too does not seem to be related to the Laurales in most of 1 ts Seatures, I would thinik it $11 \mathrm{kely}$ that valvulsr dehiscence arose by parallel evolution in this family too. 
Mornhology and vascularization of stamens. Recent investigations in the woody Ranalea have led to the suggestion that the most pmitive anglosperm stamen is a three-trace leaf-11ke organ without differentiation into anther, connective and filament (see lames, 1961). The stamen of the Honimlaceae are considerably advanced from this form, although Doryohoma has a marked prolongation of the vascularized connective beyond the anthers (Honey et al., Plg. 29). It 1 q quest1onable whether this Iong tapered extension is a primitive feature as it apparently is in Belliolum of the Winteraceae (Ba1ley and Nast, 1943a), or a secondary modlfleation as has been suggested for atamens of certain species of Magnolig (Canright, 1952). There is a slight proIongation of the connective beyond the anther in Hedrearya and Laure 120.

In Laurus, Umbe1 Iulamia and Laure21a, as noted, and in Doryphorg (personal observation) the vaseularization of the etamens, including their appendages, is so varled as to make $1 t$ diffleult to alscern any basic type. In theee genera the vascular supply to the appendagea may or may not be independent of that to other parts of the stamen. All genera had some stamens which conteined 1solated vascular strands. In Dorsphore such strands occurred within the leas-11ke appendages. In contrat to the stamen 1llustrated in fig. 29 of Money et al., many etamens had appendages In which the vascular trace underwent varying degrees of alchotomous branching. This branching, coupled with the occurrence of 
18olated strands in positions where one would expect parts of dichotomous branches to be, suggests that the condition in which the appendage is vascularized by an unbranched strand is a derived one. I found too that one or both of the lateral strands, present in the stanen 11.ustrated by Honey et al.. are absent in some stamens. Some other stamens had the strand to an appendage fused to another lateral one, as illustrated in flg. $57 C$ of Melville's (1964) peper. The staminal appendages of Atherosperma are inserted at the base of the stamen and their vascular supply is Invariably Independent of that to the rest of the stamen. In general, the appendages lose part and finally all of their vasularization ae they are reutuced in size on the stamens and staminodes of Leunue and Doryphora (Honey et al.,.) Laurus aná Unbelzularia (Kasaplig11) and in Laurelia. As already noted, there are exceptions to this in Laurella.

If each staminal appendage is a staminode, as claimed by Honey et al., then some of the stanens of Laurelia. Umbelzularia, Launus and Doryphorg are three-veined if one 1 gnores traces to staminel appenaages and may therefore represent the putat1ve printive vaseular condition of the Ranalean stamen.

Melville (1963) has Interpreted the stamens of the Laurales In the 1 ight of $\mathrm{hl}$ d Conophyll theory, which takes sone account of the Telone theory. He has based his interpretation on the vascularization of the flower and takes 11ttle conslaeration of the morphology of individual stamens. According to this 
interpretation (ahown in part in fig. 65 of Helv1110's paper) each stamen of Doryphore. Leurelia snd Umbelluharla is equivalent to a segment of the male flower of Hedrcarra. This segment consists of a tepal and the stamens which are borne on what Melv1lle interprets as the fused inner part of the tepal. Ten such epiphyllous stamens are shown in the flgure. By reduction and partial sterilization the supericlally similar stanens of Laumel1a, Dowrohora and Imbeliularis have evolved by proceases which are not ldentleal for all genera nor even for all etamens within a single flower (as in his description of Umbellularia). I find no mext in this theory for the following reasons:(a) Superfleialy simllar stamens, even within a alagle species, because they have a varled vasculartzation are regarded as having evolved in different ways fron one another. By implication, if this were true, morphological alm1larit1ea between certain stamens on a single flower would be due to parallel evolution because their vascularization was diffe ent. This seene to stretch the arm of colncidence to the breaking point. (b) I have stated how the atamens of Peumus and Monimia provide a Ink between the Atherospernoldeae and Monimioldeae in that they appear to resemble stamens of Hedycarya except that they bear the vasculated staminal appendages. With this link it seems that the stamens of Hedycarrs on the one hand and Laurel1g on the other could be derlved one from the other without the complicated processes which Melville has proposed. 
Vascular1ation of carpels. It 18 now well established that the nost primltive form of carpel in the woody Ranales appears to be the conduplicate type, in which two rows of ovules are vasularlzed by branches from a median dorsal trace and two marginal ventral traces. (See Eamee (1961) for deta1ls.) It is possible that in 1 ts most prinitive condition, the median trace is double in nature, in keeping with the theory that the two-trace unilacunar nodal pattern 18 the most primstive (Carlquist, 1961; Tucker and G1fford, 1964; Swany, 1964). Bailey and Swany (1951) and Eames (1961) have indicated how this type of earpel could be nodifled in various wayo to give rise to the follicle and achene.

If, as aeem Iikely, the unlovulate carpels of the Moninlaceae have been derived from the conduplleste type, then the aownwardy directed branches of the dorsal trace in Hedvearys and the eupraovular branches of the ventral trace, may represent traces to fomerly existent ovules in the ancevtors of Hecrearya et al. This hypotheels assumes of course, the conservatiam of vascular traces. That the supraovular traces in Hedwcarva are in general paired, suggests that the ovulea in the ancestral carpel were in two rows, as in the conduplicate carpels of the Winteraceae, for axample (Balley and Nast, 1943b). Presumably too these palred traces were completely separate from one another in the ancestral carpel. In other worde, the palred supraovular traces in Hedycarra are the result of incomplete fusion of two ventral traces. 
Kasap11g12 suggested that the ventral trace in the carpel of Uabellularia represented the two fused merglnal (ventral) traces, on the grounds that 1ts double nature was evident from teratologieal specimens. In these, the trace blfurcated winin the ovule. There are some unlovulate carpels within the woody Ranales which do have two ventral traces, fox example, some carpels of Sarandira (Swany and Balley, 1950). Eames (1961) noted that in "higher orders, solitary basal ovules may have two traces - one from each ventral vein".

It hes been noted that Laurella lacks a supraovular trace. Money et al., 1liustrated such a trace in the related Atherosperns (1n their 19. 39). This afrords a link between the carpels of Hedycarya and Laurelis and Indscates that the ancestral carpel of Laurel1a would have possessed a supraovular trace. 


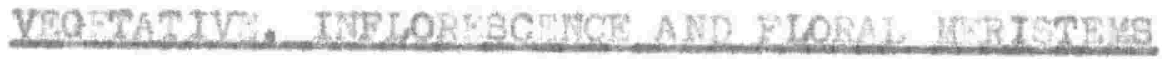

\section{Introduction}

The toralnal bude of shoots of female Hedycarye and Laurolita trees were sectioned to permit colparizon of vegetative, inflorescence and rloral aristems. To ny knowledge, this is the flrst stuay or meristema within the fanily.

Time ald not permit a study of seasonal changes in the structure of the shoot apex. Bude were collected during the epring, at which time the apleal merlateas of the shoot were pertleulariy active. Insuffieient bude were sectioned to obtain a range of sizes for maximal and minimal plsstochron atages and therefore the 11 gures quoted refer to a 11 atted number of samples. Terminal budis were not eectioned from male Hedycarre plants. It 12 of Interest In this respect that Kasaplishli found coneldereble afferences in the ahape of the vegetative apleal meristeme of ale and fenale piants reapectively. In Laurug. These aplcee did however have elatiar cytohletologlcal zonation.

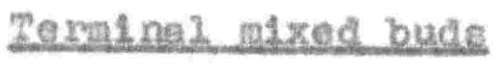

Longltudinal sections of terminal buds of Heckearys and Laurelis are 111uetrated in f1gs 1 and 2 of PLATF 14. The ghoot apex of Hedxcaxye 10 approaching asxinal surface area and that or Laurolia 1 e near minlmal area. In fig. 1 the two outermot leeves of Hedycarya encloee young axillary meristems. It cannot 
54.

be determined at this stage whether these meristera will give rise to axillary vegetative buds or inflorescence buds. It is anticlpated that they will in fact give rise to inflorescence buds which will flower the followling spring, since the bud terminated a shoot which had borne flowers and not vegetative axillary buds, for several seasone. Similarly in fig. 2, a putative young inflorescence bud 1 s in the axil of the lovernost right-hand leef in Laurelia. The terminal mixed buds of the two genera do not contain bud scales, in contrast to Laurus and Umbellularia (Kasapligi1).

The vegetative choot apex

In both genere the vegetative apical meristem has a twolayered tunica (PLATE 15, fig. 1; PLATE 16, flg. 2). TWOlayered tunfeas have been found in all woody Ranajes so far Investigated, with the exception of Notaphoebe (Isuraceae) which has a three-layered one (a1fford, 1954).

At maximal surface arca the apex is convex and at mintmal area approximately flat in both genera. In Hedyesrys it is approxinately $215 \mu$ wide and $53 \mu \mathrm{high}$ at maximal area (PLATE 15, 1g. 1); in Laureila it is $160 \mu-193 \mu$ wide and $48 \mu-64 \mu$ high at this stage. At minimal area the shoot apex $1890 \mu$ wide and Blightly convex in Hedvearve and $46 \mu$ wide in Laurelia (PLATE 16, f1g. 2). The aploal neristem is thus somewhat larger in Hedycarve. The dimensions of these aplces lie within the limits of maximal and

* Measurements are made at the adaxial level of insertion of the flrst visible pair of primordia. 
minimal sizes recorded for the vegetative apices of 6 genera of the Lauraceae (Kasaplig11).

At the maximal area phase, the apical meristems of the two genera are clearly divided Into the cytohistological zonation characteristic of Umbellularia and Laurus (see fig. 96 of KasapliglI's papor) and other woody Ranales (Glfford, 1950) as well as many other alcotyledons (alfford, 1954). In Laurelia and Hedrcarya the central initial cells of the tunica and corpus do not have the markedy larger cells and "huge nucle1" characteristic of this zone in Umbeliularia and Laurus (Kasaplig11). As noted by Kasaplig1I and others (see GIfford, 1954) the cytohistological zonation was not very distinct near the minimal phase of plastochron (compare flg. 1, PLATE 15, with P1gs. 2 and 3 of PLATE 16). At this phase too, the inner (T2) tunloa layer was less regular because of the occurrence of some periclinal alvisions within 1t (PLATE 16, fig. 3). Gifford (1950) commented that if one used the term tunica in 1ts strictest sense, as layers in which invarlably anticlinal divislons oceur, there would be only a single tunica in woody Ranales. However as the subjacent layer primaxily divides anticlinally and therefore predominantiy givea surface growth, I shall follow alfford (1950) and others and refer to It as a second tunica layer. PLATE 16, $1 \mathrm{gg} .1$ 111ustrates a transverse section of the shoot apex of Hedvcarya through the T2 layer. The youngest palr of leaf primordia are jolned to this layer in the photo. It can be deduced from this section that 
the apleal merlstem 1s approximately circular in cross section. Initiation of primordis

Leas, bract and tepal primordia are initiated in a gla1lar way by periclinel divisions in the T2 layer on the flank of the vegetative, inflorescence or lloral meristems. This method of origin, in which one (or more) subsurface layers of the meristem undergo periclinal alvision, is comon in both dicotyledons and monocotyledons (Esau, 1953). In Hedversys and Laurel1a these divisions are followed by antlelinal divialone in the Th (outer tunica) layer and anticlinal and periclinal divisione within the T2 and subjacent layer, to form a protuberant primordium (PLATS 16. 11g8. 2, 3; PLATE 20, f1g. 1). The primordiun grows for a time by general cell enlargement and division in varying planes (PLATB 17, Plg. 1) but at a later stage sub-apical initials arise, as in Umbellularia (Kasapl1g11), Drimys winteri (a1fford, 1951; Tucker, 1959) and many other ang108perms, to form regular layers of cells. At a later atage too, marglnal and adaxlal basal meristems arise, as described for Drimys winteri by Tucker (1959) and alford (1951).

The inflorescence meristem

The inflorescence merlstem axises in the axil of a leap primoralum when it 18 one of the third palr of primorala from the vegetative apex. The inflorescence mexistem in Drimss winterd also arises in the axil of the third youngest primordiun from the vegetative apex, but in this case the primordium $1 \mathrm{~s}$ a bract, 
not a leaf (Tucker, 1959). The meristem is initiated by anticinal divisions in the T1 and T2 layers and perielinal divisions within the T2 and subjacent 1ayer. A mound of t1ssue $1 \mathrm{~s}$ formed which is separated from the surrounding vacuolating parenchyta by an are of several layers of rlattened merietenatic cells which sehnidt (1924) called the shell zone (PLATE 17, 19. 2). At the stage shown in the f1gure and at subsequent stages, the mexisten has two tunica layers, as in Drinys waters (Tucker, 1959) and Umbellularia (Kasapligi1). Durling the production of bracts, the inflorescence apex exhibits plastochron changes almilar to those of the vegetative aplees. Thus the inflorescence apex 1s flat near minimal area (PLATE 18, flg. 2; PIATK 19, flg. 1) and convex near maximal surface area (PLATE 19, fig. 2). The putative inflorescence bud of Laurelis which $1 \mathrm{~s}$ shown in PLATE 14, P1g. 2 and PLATE 18, I1g. 1 , has two palrs of bract primordia and difers from the other buds sectioned in the extent of the internode between the palrs of bract:. The lowest pair (one of which can be seen in part in PLATE 14, $19 \mathrm{~g} .2)$ are inserted at the base of the 1nfloresence axis. This elongeted internode can be contrasted with the more typical one of the inflorescence shown in section in PLATE 19. Iig. 1, which bears three palrs of bract primordia. Part of one of the lower pair of bract 18 on the left hand slde of the photo. Presumably these early differences in internode length of alfferent Inflorescences foreshadow the observed differences in the length of basal Internodes of various mature inflorescences (Chapter 2). 
In Hedycarve the first pair of bracts were indtlated when the femele inflorescence was a convex mound $40 \mathrm{phigh}$, with a widh (measured across the 1ear axi1) of $150 \mu$. These bracto were $115 \mu$ long and in the axil of the fourth youngest palr of leaves when the vegetative apical meristem was inftiating the flfth pair of leaves.

The vegetstive and inflorescence apices have similar cytohistolo ical zonation, as seen by compering approximately almilar plastochron stagee of vegetative and inflarescence meristems of Laurelie in IIg. 1 of PLATFS 17 and 19. The T2 layer in vegetative and infloresence apices of Laurelia 18 somewhat more elongated verticaliy than this layer in the meristems of Hedycarra (compare PLATE 19, fig. 1 and PLATE 16, P1g. 2 with PLATE 15, fig. 1 and PLATE 18, 118.2$)$. The dimensions of inflorescence and vegetative meribtemo were approxinately simliar to each other within each genis, as in Uabeliularia (Kasaplig11).

\section{The floral meriatem}

The floral mextstem of both genera axises in the axil of a bract primordium, elrea $1000 \mu$ in length (Hedvearva) and cirea $700 \mu$ In length (Laurelia), when 1 it is one of the third pair of primordia from the inflorescence apex. Its intilation and early development Is similar to that of the jnflorescence neristem. PLATE 20, 118. 2 11lustrates an early stage in the development of a Ploral meristem of Laurel1a. One of the cells of the TH layer of the young merigter is dividing anticinaliy and the results of a recent 
periclimal division in the T2 layer ean also be seen. The ahell zone is at an early stage of development. One of the celis of this zone is labelled "s". A later stage 1s 1liustrated for Hecivary in PLATE 19, 1sg. 2. The shell wone is now nore prominent and as noted by Tucker (1959) for 2rinys whtex $1 t$ has a greater number of layers towards the adaxiald alde of the meristem. At this atage the tunica 1s elearly two-leyered but a Sew periclinal divisions were apparent in the T2 Layer. In 1 ts early development the loral meriatom is in a atate of transition sron the tunica-corpus conflguration typical of vegetative aplces to the mantle-core configuration of many floral aplces (olfford, 1954; Tuoker, 1959). Thus as in many plests, the tunica which consists of a 51 layer of invariably anticlinally dividing celle and a T2 layer of precominantly anticlinaliy alviding colls and compus - which consists of oellg which divide In various planes, are replaced by a multilayerea meristematic mantze of cella overlying a vacuolate and non-meristematic core. When Aregolre (1938) introduced the mantle-core concept for reproductive aplces he coneldered that the reproductive apex had arisen de novo. It has since been amly demonstrated that the reproductive apex, when 1t does differ from the vegetative, has originated by a reorganiation of the vegetative apex (Philipzon, 1949). Thls reorganisation occurs in a number of plants by the peripheral zone of the corpus extending down the flanks of the

* I.e. adaxial to the inflorescence axis. 
agex and comprising, together with the tunsea, the meristematic mantle (Gifford, 1954). As the tunica is a discrete part of the Plorel aplces of Hedycarve and Laurelia. I shall follow sone authors (e.g. Tucker) and refer to it as part of the mantle. Although the fioral apices of Hedycarva and Laurelis are organized into a mantle of relatively non-vacuolate deeply ataining cella overlying a core of vacuolate cells, from the stage of tepal initiation onwards, they display an unusual feature. For, within the vacuolate core a considerable number of cell alvisions were observed, even at a time when the floral apex had almost ceased its activity. Such divisions, were not of course nearly as frequent as those within the mantie.

When the inflorescence apex has completed the inftlation of bract pairs in acropetal fashion, it 1o transformed into a floral apex which terminates the growth of the inflorescence axis. This terminal floral merlsten is ahead of the subjacent palr of 1 oral meristems in 1ts early development. Thus, in PLATE 21, the terminal bud of a male inflorescence has a short pedicel and well developed tepal primorda (rig. 1). In the subjacent palr of floral aplees of the eame inflorescence, there is virtually no pedicel present as yet and the tepal primoraia are just being inltiated (r1g. 2). A marked contrast to vegetative and inforescence aplees of both genera is found in the lack of any vertically flattened $\mathrm{rib}$ meristem in the floral aplce. 
The Eloral_merdstem in Hedycaxra

The floral apex of male and female plants usually producer a pair of bracts at the base of the receptacle. Their midribs $21 \mathrm{e}$ in the frontal plane which is perpendicular to the sacittal plane which longitudinaliy bisects the subtending bract and inflorescence axis. A nale floral apex with young bract primordia on 1ts rlanks is shown in fig. 1, PLATE 27. At this stage the floral apex, excepting the terminal one, 1s tilted towards the inflorescence axis. As seen in apical view the floral apex and bracte have an elliptical shape (I1g. 1b). The short axis of this ellipse 1les In the sagittal plane, as in Drimye lanceolate (Tucker and Gifford, 1966). A male bua was sectioned when the palr of bract primoraia were $70 \mu \mathrm{high}$. At this stage the apex had a diameter along the frontal plane of $130 \mu$ and a helght of $32 \mu$. The apex was in a state of transition from the tunica-corpus to the mantle-core configuration. The eentrally situated zone of corpus initials, a characteristic of the vegetative apex at maximal surface area, was still apparent. However, the lower cells of this zone were more vacuolate in the young floral apex. The perlpheral zone was less well marked than in the vegetative and inflorescence aplees and Its lowermost cells were more vacuolate. Rib meristem was still present but less extensive and not as vertically flattenea as in the inflorescence and vegetative aploes. The T2 Layer was well maxked with vertically elongated cells, although some periclinal alvisions were observed within $1 t$. 
After tepal primordia have been formed, at a stage when the outeruat stamen or carpel primorda are being intiated, the meristem has a mantle of 5-6 irregular layers in male buds (PLATE 21. fig. 1) and 6-8 layers in female buds (PLATE 22, P1g. 1). Sone periclinal alvisions were observed in the T2 layer, lrrespective of those divisions wich instiate primorda and this layer is therefore not as alscrete as it was in the vegetative apex near maxlmal surface area. By the time most of the stamens had been inftiated the mantle had been reauced to $3-4$ layere in male bud.s. Periclinal divialons were more infrequent in the T2 layer at this stage (PLATR 22, 21g. 2). Similarly in female budr, the mantle had been reduced to $3-4$ layers when the last carpel primordia were being inftited and as in the male bud at $t$ conparable atage, the T2 layer was more aiscrete than earlier, with somewhat vertically elongated cella (PLATE 23, f18. 2). Throughout stamen and carpel initiation, divisions vere observed in varying planes within the vacuolate core of the apex, to a depth of up to about 18 layere from the aplcal surface. A cell of the core is show divialng In a mele bud of Hedyenrya near the end of stamen instiation in PLATE 23, Pig. 1 at "V".

Soon after the ultinate stamen and carpel have been inftiated, the mantle of the vestiglal apex of male and ferale buds becomes vacuolate and sone of the cells of the TI layer become modifled Into trichomes, one of which can be aeen at an early stage of development at " $t$ " In PLATE 23, $11 g .2$. In the fornation of a 
trichome, the cell becomes extended upwards and protruales above the surface of 1ts nelghbours, as in the 1igure. When the trichome is about two and a half times lte original height, the nucleus has completely migrated to above the level of the surface of the vestigial apex, as in PLATX: 24, f18. 1. Hature trichones are unicellular and by anthesis, those on the floor of the receptacle are up to $900 \mu$ long and taper to a polnt. They measure up to $50 \mu$ in width and are widest near their base. Their thicis lignifled walls are about $10 \mu$ thick. At anthesis, their nuelei, which are approximately centrally situated, show signo of degenerat1on.

At the gtage shown in $11 \mathrm{~g}$. 1 of PLAT 24, the apical meristem had completed the inltition of earpels and 1 t can be seen that quite a large vestiglal apex is present. A fev aivisions were still occurring within the mantie and core. DIvisions had ceased ahortly before the stage 111ustrated in $11 \mathrm{~g} .2$. At a comparable stage in the development of stamen primorda the vestigial apex of the male bud is in general maller, measuring about a third the width of the female one.

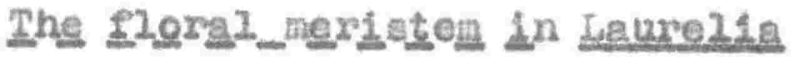

After tepal initiation the floral meristem of male and carpellate flowers has a mantle of $5-6$ irregular layers overlying a vacuolate core. The T1 layer was vertical ly elongated at this and subsequent stages. Near the ond of stamen initiation in the male flower and earpel initiation in the carpellate flower, the 
mantle is reduced to 4 irregular layers and the T2 layor is now somewhat elongated vertically. Some periclinal aivisions were apparent within the layer and therefore disturbed its discreteness. Fhroughout stamen, staminode and carpel initicton, alvisions in varying planes were noted within the vacuolate core to a aepth of approximately 12 layers from the surface of the apex. Soon after the witimate stamen or carpel has been indiated in the male or female buds, the cells of the mantle of the small vestiglal. apex become markedly vacuolate (compare Plo 1 and 2 of PLATE 25). Trichores are formed on the floor of the receptacle and on the vest1gial apex in a manner similar to that deseribed for Hedycarya. At anthesis those on the floor of the receptacle of the carpellate flower are about $500 \mu$ long, $30 \mu$ wide. They taper to a polnt but affer from those of Hedrcarva in that they do not bulge outwards near their base. At this stage many of them to not have heavily thlckened walls, although the approximately centrally bituated nucleus of each is showling signs of degeneretion. The largest trichomes in taurelia are on mature fruits. They are unicellular, approximately $40 \mu$ wide, with walls $10, \mathrm{thick}$ and up to 12 the long (PLATE 26, Ig. 1).

The Initiation of tepale

\section{Hedrearre}

A male bud is shown in lateromplcal viev after four tepals have been inltiated, in PLATE 27, 19. 2. They enclose a domed rloral apex. Bracts analogous to those shown in $1 \mathrm{~g} .1$, have been 
exclsed except at their bases ("B"). In 1 lgs. 2-6, the tepals of male buds have been numbered consecutively, beginning with the oldest:. It can be seen that elther (a) the Ilrst tepal arises closest to the subtending bract ("B. B.") as in figs. 2, 3 and 5; or (b) the first tepals arise as a pair, closest to the pair of bracts $\left(" \mathrm{~B}^{\prime \prime}\right), \mathrm{as}$ in figs. 4 and 6 . Following the instiation of the first tepal or pair of tepals, the other tepals arise in close succession in a variety of positions, as shown in figs. 2-6. In some cases, after the flrst tepal has been initiated, a pair of tepals are formed simultaneously, closeet to the pair of bracts (rig. 5).

The male 1 oral apex is a convex mound with an ad-abaxial diameter of about $220 y$ and height of about $60, y$ above the level of insertion of the subtending bract, when the flrst tepale are initiated (PLATE 21, fig. 2). It is therefore somewhat larger than the female inflorescence apex when it inflated the flrst pair of bracts $($ see $p .58$ ).

\section{Laurelia}

In both nale and carpellate flowers, the firot sepals arise as a pal $r$, with their midribs in the frontal plane. These tepals and the enclosed domed apex ("A.M.") becone comparatively large before other tepals are initiated (PLATE 27, figs. 7, 8). The other tepals (see $\mathrm{PLg}$. 9) are inltiated in elther clockwise or ant1clockw1se succession. The first formed tepals of Laurelig

" This 1s argued on the basla that the largest tepal ("2") represents the oldest one. This appeared to be the case from an exanination of many buds at different stages of tepal development. 
resemble the pair of brects comonly found in Hedycarys, which are inserted above the subtending bract, in that they are decussate to the subtending bract and inflorescence axis and are initiated some time before the tepals in Hedycarre or other tepals in Laurel1a. However it seems best to regard this pair of appendages a tepals in Laurelia for they resemble the other tepals in shape, size and vacculature and are inserted only slightly below them. It is poseible that these lower tepals In Laurelia have recently evolved from bracts analogous to the pais commonly found on the floral axis of Hedycarva.

The floral apex of male and carpellate flowers of Laurel1a Is a convex mound with an ab-adaxial alameter of about $72 \mu$, but with its largest diameter of about $175 \mu$ at right angles to this, at the time when the first pair of tepals are initiated. It has a height of about $70 \mu$ above the level of insertion of the subtending bract. It is therefore comparable in size to the male floral apex of Heaycarya at this stage except that it $1 \mathrm{~s}$ more flattened in the agltal plane. Discussion

The absence of bud scales in Hedvearra and Laurelig has been contrasted with their presence in Laurue and Umbellularia. It is a characteristic of many trees and shrubs of the New Zealand flora, including some occupying subalpine habitats, that during the winter, apical buds are not sheathed by special protective structures, in contrast to "most trees and shrubs of the North 
Temperate Zone" (vardle, 1963). Bud scales are also not present in the Nev Zealand species of Bellochmiedia of the Lauraceae (pers. comm. G.H. Roper, V.U.W. Botany Department). Perhaps the frequent absence of bud scsles in members of our flora is a reflection of our comparatively oceante cllate which allows of vegetative growth throughout most of the wlnter, at least at lower altitudes. Absence of bud scales in many subalpine plants may be a reflection of the relatively recent derivation of these forms (Dawson, 1963; Fleming, 1963). It should be noted however that buds are frequently protected by the hairy nature of the young leaves, or by gummy exudates or the sturdy nature of the young leaves in the outermost part of the bua (pers. comm. Dawson). No major alfferences were found between the apical meristems of Hedvcarva on the one hand and Laurella on the other, although minor differences were present, as outlined in the foregoing pages. Kasapligil stated that the "structure of the apleal meristem of Inflorescence buds, as well as that of flower buds, $1 \mathrm{~s}$ dmilar to that of the vegetative shoot apex", in Laurus. This conclusion seems burprielng in view of my own results on two members of what 1 considered to be a closely related fanlly and in the 11 ght of Roper's (pera. comm.) observation that the maturing roral apex of Beilschmiedia tawa has the typioal mantle-core configuration. It is however apparent from Kasaplig11's description, photographs and drawings of the floral apex of Laurus, from the time of petal Injtiation onwards, that the mantle-core coneept could be applied 
to 1t. Kasapligil. wrote that the "corpus" reglon of the floxal apex ordginates from the peripheral zone of the corpus of the Inflorescence apex and 1 s therefore, I conclude, not strictly homologous to the entire corpus of the inflorescence and vegetative apices. He added that after formation of petal primordia "the zonation of the corpus is very inconspicuous" and "the aplcal meristen, consisting of only 2 or 3 cell layers, appears to be very cuperficlaz". It does not seem important to the writer what terminology one uses in comparing Ploral, inflorescence and vegetat1ve aplces provided that the deseriptions are accurate. It is nov well established that, as Newman (1965) aptly expresses 1t, "the features 'pecullar' to the 'reproductive' apex are those peculiar to an apex ceasing growth, or even to an apex with an increased tempo of growth prior to that cessation". The rloral apices of Laurelis and Ledvarye do not strictly conform to the mantle-core conflguration because of the unusual feature that cell divisions occur within the core region. In this respect these floral apices share qualities of the 'typleal' vegetative and 'typical' floral aplees. It is of Interest that within a single Ranalean genus, Drstmus, one species has been described as having a floral meristen with the typical nantle-core configuration ( 2 . whtert, Tucker, 1959) and another specles has been described as having a Ploral aeristen with a tunlea-corpus type of conflguration (Tucker and offford, 1966a).

The absence of mb merlatem in floral aplces of Laurelia and 
Hedvagry Is a somewhat unusual feature. Newnan (1965) stated that reproduct Ive aplces frequentiy have a more pronounced $\mathrm{rlb}$ meristen than vegetative ones. He attributed this to differences In rates of extension growth. Thus in Mlchelig the vegetative apex has a weak $\mathrm{rlb}$ meristem but the floral apex, which produces laterals at a much faster rate, has a prominent rib merlatem. Whether the absence of rib meristem in the floral aplces of Laurel1s and Ledrcerys Indicates that 2oral appendages are produced at a alower rate than leaves is not known.

The fact that atratification of the T2 layer in the rlorel apex of Laurelia and Hedvegrye is alsturbed by periclinal divisions after tepal inftiation, 18 also a feature of the flora aplees of many plant:, Including Drfmye mintert (Tucker, 1959), PseucoLintera (Sanpson, 1963) and Laurus (Kasap11g11).

Rames (1961) stated that the two-layered tunica seens to bo the primitive form in angiosperms. While this type is comon Within members of primitive families, I would share cifford's (1954) viev that the apical merlaten should be thoroughly stualed in many more families before any poselble trends in aplcal structure can be envisaged. 
STAMEN ONTOONNY AND THE DVVLOPIT INT OF UICROSPORANOIA

AND WALE QAMETOPHYTS

\section{Inltiation and eariy growth of stamens}

Hedycarve

After tepal initiation the floral apex increases in diameter and convexity. When stamen initiation legins the apex is at111 tilted towards the inflorescence axis, with the exception of the terminal flower bud. At this etage the apex is either circular in transection or is still flattened in the saglttal plane to as little as two-thirds of the diameter along the frontal plane. It mea wures $290-410 \mu$ in diameter along the frontal plane and 215-290, diameter along the sagittal plane and 1 a approximately $35 \mu$ in helght. The stamens are initiated in centripetal fashion and at least the outermost ones are formed in splral succession. The other, more internal stamens are so closely packed together that I was unable to determine the direction of the spiral or whether there were a number of intersecting spirals or even closely packed whorls of stamene.

Each stamen is initiated by localized anticinal divisions In the T1 and T2 layers on a rlank of the apleal meristem. The cella of the T2 layer w1thin this region increase their vertical elongation to produce a slight buige before any periclinal aivisions occur. The nuclei of such cells are also conaplcuously vertically 
elongated and therefore spheroidal rather than spherical in shape. The first periclinal divialons occur in the T2 layer and are soon followed by perlelinal, anticlinal and oblique cell divisions In the subjacent two layer and the priaordium becomes a hem1spherical mound (PLATE. 27, fig. 14) which becomes more conical as it enlarges (fig. 15). Only anticlinal divisions were observed within the protodemal layer of the primordium.

In general, the subprotodernal cells near the tip of the stamen divide in periclinal and anticlinal planes, but the aubprotodermal celle on the flanks aivide in an anticlinal plane With respect to the ad or abaxial surface of the primordium (1.e. in a horizontal plane). Cella in the central axis of the primordIum divide mainly in a horizontal plane. The foregoing divisions result in a primordium which consista of relatively discrete vertical flles of cells (PLATE 27, I1g. 10). When the primorala are about $110 \mu \mathrm{hlgh}$ they are finger-1ike protuberances and procambium has extended acropetally into their base.

During the period of stamen initiation the receptacle becomes concave so that the outermost stamens are inserted at a level above the inner ones. This is shown in a median longlsection through the frontal plane shown in silhouette in Plate 27, rig. 11. Hote how the tepals curve downwards towards the centre of the bud. At this stage, in which stamen initiation is almost complete, the apex ("A" In the 1igure) Is either flat or slightly convex (PLATE 23, P1g. 1). 
Laure 110

The floral apex of male flowers has a diameter of approximateIy $150 \mu$ at the beginning of stamen initiation and is a low convex mound about $12 \mu \mathrm{high}$. The floral apex of carpellate flowere is of a similar s1ze, but concave at the beginning of stamen and/or staminode initlation (DLATE 26, fig. 2). During the course of stamen and staminode initiation the receptacle become concave, as in hedycarye.

The initiation and early growth of stamers and staminodes is amilar to that described for Hedycarya. During stamen initiation the cells and nuclei of the $T 1$ layer are more vertlcally elongated than in Hedycarya. Fig. 16 of PLATE 27 11luatrates a young stanen primordiun in (a) lateral ad-abaxial view. Part of the aplcal meristem ("A.M.") 18 visible. In (b) and (c) the same primordium 1 s shown in adaxial and abaxial view. An older primordium is shown in $\mathrm{fig} \cdot 18$. Development of microsporanghs Hedycarya

Archesporial cells were present when stamens were approximately $150 \mu \mathrm{high}$. There were four groups of archesporial tissue, each representing a future pollen sac. Dlfficulty was experienced in detemining the preclse $11 \mathrm{mits}$ of the archesporial cells for the following reasons.

(a) Archeoporial cells were not sufficiently alstinct in appearande from neighbouring hypodermal celle. 
(b) Transverse sections were not made at this stage of stamen development. It could not therefore be stated with exactitude whether each group of archesporials was one or more cells wide as seen in cross section. From an exaranation of longltudinal serial sectiona, 1 t appeared that each group of archesporlals was at least two cells wide in cross section.

(c) Some cells which resembled neighbouring archeaporiala (ane of the latter were dividing into primary sporogenous and primaxy parietal cells) were undergoing a final anticlinal division before apparently functioning as archesporials. It is presumed therefore that some cells which appeared to be archesporial cells anght in fact divide antlelinalig before functioning as archesporials.

As aeen in longltudinal section of a stamen, each group of archesporial cells consieted of a row of about 7-9 hypodermal cells which extended most of the length of the stamen. A longlaection of part of a stamen is shown in f1g. 12 of PLATE 27. The archesporial cells ('Ar') had a darker stalning cytoplasm and somewhat larger nucled than those of the contiguous epldermis ('ED'). The cells immedately internal to the archesporials were more vacuolate. Cansnga of the Annonaea resembles Hedvearya in having archesporial tissue in longltudinal hypoderinal rows (Periasany \& Swany, 1959).

Each arohesporial cell divides periclinally into an outer primary parletal cell ('Par' in Iig. 13) and an inner primary 
sporogenous cell (' $\left.3 \mathrm{p}^{\prime}\right)$. Above these two cells in the flgure, are two tlers of two cells per tier which have resulted from the anticlinal division of a primary parietal and a primary sporogenoua cel1. This was deduced from the observation thet the combined vertical length of theee two tiers of cells was comparable to the leasth of a single parietal or sporogenous cell below or, to the length of the cell "Sp $2^{\prime \prime}$ above. It was also observed thet the anticlinal walls separating the e two tiers werethinner and therefore, it is presumed, more recent than the anticlinal walls of other cells in these layers, excluding the wall separating the two cells to the right of "Sy $2 "$. These differences in wall. thickness are not clearly ahom in the flgure. The primary sporogenous cell "Sp 2 " Is still unalvided but the

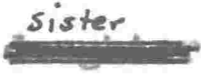
parletal cell has divided anticilnaily. At this stage the stamens are approximately $170 \mu \mathrm{hlgh}$.

The primary parletal cells undergo perielinal and anticlinal divistons to form the 5-6 wall layerg of the mature pollen sac, excluding the epldermis. The primary sporogenoug cells undergo further diviaton to form a large number of sporogenous cells. Barly stages in the development of wall layers and sporogenous cells are shown in PLATE 28, f1g. 1. In the oldest stamen visible (upper xight) 2-3 wall layers have been formed. Procambium has extended into the lower two-thirts of the stamens. The stamens are now four-lobed as seen in cross section and weige ahaged (fig. 17, PLATE 27). A later stage in the developmenc 
of the microsporangium is shown in f1g. 2 of PLATE 28 . A comparable stage is shown in transverse section in fig. 3. Large cells of two types are visible within the receptacle and stamen connective. One type is darkly staining and contalns deposits of a tannln-11ke nature, as $1 \mathrm{n}$ Laurus and Umbellularie (Kasapligil, 1951). The other type has a large vacuole and peripheral protoplasm at maturity and reambles the "1dioblast1c secretory cells" of the Louraceae (Kasaplig11, 1951) and the "spherleal secretory cells" which Money et al (1950) describe as a characteristic feature of many famllies of woody Ranales.

The stamen 1llustrated in longltudinal section in sig. 1 of PLATE 29 contalns nearly mature sporogenous tissue. A few sporogenous cells were st1.1 undergoing division and some anticlinal divislons were apparent in the wall layers. Most of the cells of the sporogenous tissue are maturing into mierospore mother cells. They have a denser cytoplasm and larger nuclel than those of the wall layers. The innermost wall layer, which encloses the gporogenous t1ssue, is now alfferentiated as the tapetum. Tapetal cells are less mattened tangentially than the other wall layers and they have a denser eytoplasm. The pollen sacs extend for most of the length of the stamen, which lacks a filament. The uppermost part of the stamen is sterile. Procambium has now extended acropetally to near the tip of the stamen, as in taurelia at this stage, but this cannot be seen in the figure. 
Laurelia

Sections were not obtalned of stamens at the archesporial cell stage. The gtaminal glands are inftiated when the wall layers and sporogenous tissue are at an early stage of development. There axe fewer pollen graing per stamen in Laurelis than in Hedrearya. This is because the stamen of Laurella has only two pollen sacs, which are shorter and each sac in transection has fewer grains than in Hedvearye (compare flgs. 1 and 2 of PLATE 39, in which pollen mother cells are at prophase I). Durling the development of sporogenous and wall t1ssue, which is s1m1lar to that described for liedvearyra, the stamen becomes somewhat apathulate (PLATE 27, fig. 19), being flattened dorgoventra1ly. In later stages of development (f1gs. 20 and 21) the staminal glands enlarge and the central part of the stamen broadens. Mature stamens have a dorso-ventrally flattened fllament which occupies up to almost half the length of the stamen (PIATE Q. PAs. 1-10) 
section. Their eytoplasm 1. denser and nuclei consterably larger than in wall layer tisaue. Microsporogensis and the tapetum Hedicearys

Helosis begins in the pollen nother cells when stamens are 1135-1180 $\mathrm{high}$, in comparison to stamens of Laurelia which are $660-1020 \mu \mathrm{hlgh}$ at this stage.

Although the tapetum ig predominantiy one cell thick, it Is two cells thick in places, in both genera, owing to the occurrence of some periclinal and oblique divisions while the tissue was maturing.

Nuclear aivision is asynchronous in the tapetum and begins when the polien nother cells are at elther early leptotene or the synizesis stage of prophase I, as 1 s commonly the case in angiosperas (I1J1ma, 1962). By early anephase I most of the tapetals are binucleate. As in Laurelia the tapetals are considerably vacuolate when they undergo nuclear atvision (PLATE 33. 11ge. 1 and 2) with the axis of the apindle aligned etther parallel or at right angles (flgs. 1 and 2) to the adjacent aurface of the pollen as; the former condition being more comon. In Laurelia the two types of spindie orlentation are found with equal rrequency. At the end of the second melotic alvision of the pollen mother cella, the tapetals had lost contact with one another and were becoming tangentially flattened and darkiy stalning (PLATE 34, flg. 2). They remain in situ during the maturation of the polien 
and are therefore of the eecretory type. Only scattered remnants of the tapetum were visible when the pollen gralns were two-celled with the generative cell lylng within the cytoplasm of the vegetative cell. It appears that nuclear aiviolon is not completed In some tapetal cells. For, when the unlcellular pollen gralns were alvialng, many stamens contained a fer tapetal cells $1 \mathrm{n}$ which mitotic p1gures were present at etages from metaphase to telophase. These appeared to be abnormel stages with groesy Lattened chromosome groups and chronosome bridges in Bone at late anaphase. They reaemble the "sticky" type of tapetal division (Haheshwar1, 1950). Desplte a eareful search no premetaphase stages were found, which suggests that the mitotic Plgures had been present since the time at which the pollen grains were Initiated. Unfortunately no flowere were sectioned between pollen mother cell aelosis and pollen grain mitosis stages. One of the abnormal tapetal cells 1 a shown in PIATE 33, 11g. 3. I can find no mention of comparable "frozen" tapetal mitot le figures In the literature, and Maheshwar (1950) stated that when the sticky type of divielon occurs, an abnornal nucleus whloh may be distorted In shape, 1 r reconstituted.

Follen mother cells undergo melosis at the same thite in all the stamens of a flower. Desplte the conolderable length of polien sacs, prophase I stages are synchronous withln each aac, although adjacent ones ay be at a slightly different stage s.g. early leptotene in one aac and synizesis in the adjacent one. 
After prophase I there is some variation in stagea within a single sac, but most mother cells are at the same stage. For example, one sac contalned a range of atages from interkinesis to late anaphase II with most celle at metaphase II and early anaphase II.

From leptotene onwards, wall material is laid down inside the original wall of each mother cell and after synizesis the protoplasn loses 1ts polygonal outline and becomes rounded with continuing deposition of this material, which recent research has shown to be of a callosic nature (Waterkeyn, 1962; HeslopHarrison, 1966). Heslop-liarrison (1966) noted that deposition. of the callose wall usually beglns at late leptotene and therefore Hedvarys is typical in this respect. Waterikeyn (1962) sound that this "parol speciale" was not readily apparent when material Is stalned with nuclear stains and mounted in Canada balsan, but in both Hedveasya and Laure11a in meterial thus treeted, the "parol speciale" is visible as a bright glistening translueent zone between the original wall and oytoplasm, when gectlons are viewed under phase contrast. Durlng deposition of the callosic material the external walls of the mother cells retaln their polygonal outline and aaintain contact with nelghbouring mother cella but turing the course of melosia intercellular speces develop in the corners between adjacent cells. As these spaces increase in slze the external wall loses part of 1ts polygonal outline. The original mother cell walle can be falntly geen 
in PLTE 34, fig. 2, in which the mother celis are at telophase II. At this stage come of the midale wall layers are tangent1ally Plattened and the hypodermal layer 1 s enlarging into the endotheclun. The mother cell wall alsintegrates soon after the tetrade are formed. Heslop-Harrison (1966) noted that it is usual for stages in melosla to become progreaglvely lees synchronized between adjecent mieocytes from metaphase I onwards and this is true for Ledveryg. He attributed this to the breakdown of interconnecting eytoplaamic channels between nother cells. F1g. 1 of PLATE 34 11lustrates part of a polien sac in which the mother cells are at early synizesis, which some recent authors cons1der to be a non-artefact stage equiralent to the bouquet atage in animals (Oskala and Therman, 1956; Rhoades, 1961). Fach mother cell contalns a single large nucleolus or a large nucleolus and one or two smaller nucleoll. Three pollen mother cells can be seen in the figure with what appears to be a angle glant nucleolus embedded in the cytoplasa. Other cells (PATE 35. fig. 1) have a nuclear membrane enclosing the nucleolus and the space between nucleolus and membrane fllled with a cytoplasmiclike material which is devold of a chronatin reticulum. In some cella (rig. 2) nucleolar vacuoles were present. These sterile cells were present with a frequency of up to $10 \%$ of the total pollen wother cells in most stamens of most rlowers sectloned, Inclualng material from two different localities. They persist relatively unchanged up to the time of anther dehiscence although 
their walle thicicen and oone become ditorted in shape. The nucleolus in there cells was slightiy larger in diameter than the generative cell nucleus in the pollen graln. It is possible that the apparent lack of a nuclear membrane in sone aterile cells may be an arteract due to sectioning, an the nucled of these cells might be more fraglie than normal ones becase of the lack of a chromatin reticulum.

F1g. 3 of PLAIE 34111 ustrates metaphase - early anaphase I. Cytakinesis is of the successive type in which a centrifugal cellplate is la1d down at the end of melosis I (PLATE 35, P1gB. 3 and 4). During interininesis nucleoll reappear but the formation of a typical chronatin reticulum does not occur. During me1osis II, as found also in Laure21s, the stages are synchronlsed in both halves of a dyad. Metaphase II 18 11.1ustrated in PIATE 36 under ordinary 11 ght ( 1 g. 1) and phase contrast (IIg. 2) and in the latter Ilgure the splndie flbres are clearer. Telophase II 1. shown under phase contrast in flg. 3 in whlch the second divialon cell-plates are formed. In most cases, as shown in rigs. 1-3 the spindles of each half of the dyad are allgned parallel to each other, thereby explaining the general tetragonal arrangenent of grains in a tetrad (PLATE 36, IIg. 4). In a rev caser the aplnales are aligned obliquely to one another or are crossed at $\mathrm{might}$ angles whlch would explain the occasional tetrahedral and decussate tetrad types. Pollen grains are in permanent tetrads in the genus and Money et al., found that most 
tetrads in Hedycarva engust1fol.1n were tetragonal but that transitions to the tetrahedral type were "of not uncommon occurrence"

\section{Laurelis}

Tapetal behaviour during melosis resembles that in Hedvcarva in that nucleas alvision is asynchronous and beglns when pollen mother cells are at early leptotene. Host cells undergo nuclear division when pollen mother cells are at from leptotene (PLATE. 39. 1 g. 3) to the end of prophase I. but a few divisions were observed during metaphase and anaphase I. By interinesis most if not all tapetals are binucleate. During gelosis the tapetals of Laurelin are comparatively nore radially elongate than those of Hedycazya. Vacuolation and radia elongetion increaces auring meiosis (compare PLATE 39, 118. 3 and PLATE 40 Plga. 1-3) and before the end of Helosis II the tapetale have lost contact w1th one another. They do not undergo tangential flattening at this stage, in comparison to those of Hedvermon. However at a time shortly before the uninucleate polien gralns undergo division, the tapetalg are tangent1ally flattened, with a more finely vacuolate, coarse eytoplas and deeply staining nuclel (PLATT 4 , 11g. 1). As a result of this mattening the tapetal cells are again in contact with one another. This secretory tapetum remains in situ and becomes absorbed by the time the pollen grains are mature (PLATE 41, IIg. 2).

Pollen mother cell division resembles that in Hedycarya in 
that:-

(a) Helosis begins at the sane time in a.2 staneno of a flover and prophase I stagea are synchronous in each sac, although adjacent gace may be at a different stage of me10s1s. An unusual feature found in one pollen sac only, was that in approximately one half of the sac, extending throughout 1ts length, nother celle were at wetaphase I and early anaphase I and In the other portion of the ac wore at diplotene of prophase I.

(b) The "paro1 speclale" 18 deposited from leptotene onwards and by a1plotene (PLATE 39, f1g. 1) the eytoplasn has lost much of 1te polygonal outline. As in Hedvenrya the oxiginal (external) mother cell walls keep thelr polygonal outline for a time (PIATE 40, Ifg. 2) but intercellular spaces develop (\$1g. 2) and the orlginal wall becones more rounded ( 19.3 ). Th1s wall is ruptured when the tetrads separate.

The nost algniflcant difference in mlerosporogenesis in the two genera is that in laurelig quadripartitioning doez not occur by the depostion of successive cell-plates. Eariy anaphase I is shown in PLITE 40, P1g. 1 and in PLATE 42, 11g. 1 a pollen mother cell can be seen at th1s atage undex phase contrast, which shows the spindle Ilores particularly clearly. At the end of telophase I (11g. 2) nucleoll reappear in the nucle1 but a in Hedrearys no deflnite ehronatin reticulum is reconstitutea. At this atage 1 t can be seen that a centripetal furrow has formad around the edges of the oytoplasin, between the two nucles. 
This perlpheral furrow does not advance inwards much by the time of anaphase II which $1 \mathrm{~s}$ 1llustrated under ordinary $11 \mathrm{ght}$ (PLg. 3) and phase contrast (19. 4) In PLIV 42. Notice the etructures at the jeft equatorial side of the cell, which have the superficlal appearance of epindie fibres but in this cell are allgned paraliel to the equator. These structures, which can also bo seen in PLAT 40, fig. 3, appeared in all mother cells during melosis II. In sone cella they were aligned at $r$ ght angles to the equatorial region of the cell as can be seen in the cell at anaphase II under ordinary 1ight (1Lg, 1) and phase contrast (Isg, 2) In PTATY 43. It is possible that these structures are resianal parts of spinde flbre fron the flrst melotic aiviston and have undergone realignment in sone cells. This posslbility lo supgorted by the presence of apparent remnanta of splnale flbres at the equatorlal region of telophase I eells (PLATF 42, f1g. 2) * The centripetal furrow again becomes active and near the end of telophase II has extended to almost the centre of the cell as chown in PLATE 43 , 2Hgs. 3 and 4 (phase). At this stage a cell-plate is extending centrifugally across the equator of each half of the dyad. At a Later stage, shown in 1 igs. 1 and 2 (phase) of PIATE 4h, IurrowIng is complete and in each half of the ayad the cell-plate has completed 1ts centrifugel growth. Thig type of quadipartitioning

- Profeseor A. Frey-ilyssing of the Bw1sa Federal Inst1tute of Technology, Zurich, an authorlty on the Ine strueture of eytoplasm examined my photographs and was also of the opinion that the wtructures aight represent degenerating spindie ribres. 
In whlch there 18 a comblnation of furrowing and cell plate formation has apparently not hitherto been recorded for pollen mother cells. Fig. 3 lllustrates a young pollen tetrad with tetragonal configuration. Sone pollen tetrada were arranged tetrahedrally.

During melosis cell divielons were observed within the wall layers of the anther and were of common occurrence throughout the fllament, but by the time that the pollen grains had separated from one another the only divisions within the stamen (ercluding those within the appenasges and those foralng vasular tissue) were near the base of the fllament. During melosis, the endotheclum is not as vacuolate nor as radilly enlarged in faurelia as in Hedrcarys. The endothecium is well developed at the time of polien grain alvialon (PLATE 39, fig. 4) and at maturity it has the radial bars of thlokenlng (PLATE $41, \mathrm{flg} .2$ ).

Some stamens were sectioned in which the tapetun had aborted and was a darikly stalning zone of crushed cells around the polien mother cells (PLATE W4, 1 ig. 4). It 1s presumed that this polien sac would not have produced viable pollen in view of the role which the tapetum plays in the development of the pollen (HeslopHarrison, 1963, 1964). A pollen sac with sterile pollen, which inay have been the result of such an abortive tapetum Ia shown at left in PLATE 41, f1g. 2. However other stamens were sectloned In which the tapetum appeared nornal but the pollen mother cella were erushed and deeply stalning and thls would also glve rise to sterile pollen sacs. 
Develonmont of the pollen grains

Hedycarye

The first division within the microspores occurs at approximately the ame time in all atamens of a flower. The stamena are 1320-1710 $\mathrm{y}$ high at this stage in comparison to those of Laurel1a which are 1560-1860 $\mathrm{\mu h}$ high. Although there 18 a varlety of division figures within a single polien sac, all four cells within a tetrad are at the same stage of division (PLATE 38, f1g. 1). Waheshwari (1950) stated that this is the usual condition for plants with microspores in permanent tetrads, although in Pseudo5interg the four cells of a tetrad are not usually at the same stage of A1v191on (Sampson, 1963).

F1G. 4, PLATE 36, 11Iustrates a tetrad whortly before division begins. Some exine has been deposited on the exposed faces of this tetrad. A tetrad is shown at prophase ( $1 \mathrm{~g}$. 1) and metaphase early anaphase $(f 1 g, 2)$ in PLATE 37. The division Into unequal-sized cells is antleipated in that the distal pole of the spinale is blunter than the proximal (1nternal) one and the equator of the spindle $21 \mathrm{es}$ closer to the distal (external) surface of each nlarospore. In $\mathrm{flg}$. 3, two cells of a tetrad are shown at anaphase and in $\mathrm{Plg} .4$ division has been completed. The amaller generative cell is always cut off towaria the al atal face of the nlerospore and a "curved watchglass-shaped wall" typleal of asymetrical splndes (Steffen, 1963) separates the generative and vegetative cells. 
At the time when the polien grain 1 s undergoing its Irst aivision, the endotheclum, which as in Laumelis is consined to the exposed submepldermal part of the pollen sacs, has enlarged radialiy to near its maxlmum size, but the radlal bands of ribrous thickening are not yet present.

The generative cell. soon rounds off and the cytoplaam of the vegetative cell begins to extend around it (FLATE 38, P18.2, microspore at upper centre) and it soon comes to lie within the cytoplasm of the vegetat1ve cell (flg. 2, mLerospore at centre $r$ ght) where it is distributed at random. The eytoplasia of the generative cell is more hyaline and less vacuolate than that of the vegetative cell. During the maturation of the pollen grains, the vegetat1ve nucleus becomes less deeply ataining (as can be seen in some grains in 1 1g. 3) and this common phenomenon which also occurred in Laurelia, has been attributed to a loss in DNA content (steffen, 1963). The endothec1um now bears the characteristic bands of thickening.

Shortly before dehiscence, radlally adjacent pollen sacs of a stamen become continuous by the breakdown of all but the most Internal part of the separating wall. The midale layers at this stage are crushed beyond recognition. The epldermal celis are now tangent1ally flattened with a wavy outline, but even at the tine of dehsscence they have not broken down and many have nucled in good condition, as are those of the endotheclum. Th1s is also the case in Laurelia. 
Dehlscence is longltudinal and latrorse and occurs by the separation of cells along a IIne of weakness at the outermost part of the wall which separated adjacent radial pollen sacs. A Ilower w1th dehlseed stamens is shown in PLATB 5, I1g. 2 and in some of the starans the innermost part of the separating wall between adjacent pollen sacs can be seen. Pollen 18 shed in the two celled condition.

Haure 1 i.

Money et al., (1950) 11lustrated and described the fature pollen grain of Laurelia as spherical or somewhat ellipsoldal with a furrow which contmonly encircles the grain. In contrast to th1s monocoplate type, sone genera of the Atheroapermoldeae e.g. Atherospenas, are alcolpate. In Atherosperma the two furrows on the grain are extensive, with tapering ends which nearly meet (Money et al., 1950). In the Magnoliaceae the pollen has a relatively broad furrow on the distal face and in the related Degeneriaceae, the furrow is of distal origin too and extends around the aldes of the grain towards the proximal pole. Honey et al., commented, "The furrow 1 s much constrieted in the vicinity of the distal pole and broadens markedly on the laterul surfaces of the polien. Addstional construction and elimination of the ds stal part of the furrow would yleld a dicolpate condition..... Further extendion of the furrow unt 11 1ts tapered ends meet at the proxlmal pole would form an alternately constrleted and expanded groove which completely encircles the pollen as in .... 
Laure21. Novee-Zelandiae ..... Accoralng to such an interpretat1on, the encireling furrow would be on a merlalan as in Deseneria, and fundanentally different fros the encircling furrows of certaln Nymphaeacea, where, as shown by the coherent tetrads of Victorlas the grooves are zonal and oriented at $x$ ght angles to the polar axis ..... In the case of the Laurelieae( $(b)$, the orientation of the furrows in relation to the polar axis and to the distal and proximal surfaces of the pollen should be studied by someone having access to living flowering representatives." Now when pollen grains are in tetrads in Laurelia, there is as yet no sigm of the furrow. It is present soon after the grains have separated (PLATE 41, Alg. 1). Fortunately the separated grains do not imnediatedy become rounded and have for a time a shape which betrays the1r orfentation when in the tetred stage, with the nore rounded distal face and proximal edge preserved. When a tetrad is viewed externally such that only two of the Lour grains are apparent, 1t cas be seen that the gralns are conslderably elongated and thus thelr distal faces have an elliptical outilne. Bxanination of recently separated tetrads revealed that the furrow passed along the centre of the distal face of a grain, enclreing Its long axis and then passed along the proximal edges of the grain to the proximal pole. The two wlaeet parts of the furrow were at right angles to the proximal-aistal axis (see text-pigure 15 and Plate IV, figure 42 of money et al's paper). Thls observation

(*) Synonymous with A therospermoldeae. 
therefore supports loney et al' interpretation.

Exine is deposited on the outslde of the grein (excluding the furrow) before it $1 \mathrm{~s}$ two-celled (PLAm 45, PIg. 1). Before the flrst alvigion occurs, the grain becoses roughy sphem $10 a 1$ and the nucleus mates to one alde of the grain, away from the furrow (11g. 2) and at this stage vacuoles are precent in the cytoplasm. According to Ina Cour (1949) it it this vecuolation which leade to the migration of the nucleus. Sonetinea port of the nuoleus 10 flattened agalnst the wall of the grain ( $12 g$. 3). A stage in prophase 1: 11lustrated in PI. 4, wth a tapetal nueleus vielble to the left of the graln. At metaphase (Plg. 5) and late anaphase (Plate 46, IIg. 1) 1t can be seen that the equator of the splnale 1 s al eplacea a conslderable dietance from the centre of the cell and this aleplacenent 1 s greater than in Hedycarsa. It 18 concluded that the generative cell 1 b eut off againgt what represents a racial wall of the grain when at the tetrad stage, elnce the generative cell 1100 the maximua distance from the gerainal furrow (Plate 46, rge. 2, 3 and 4). This 18 an unusual feature as in the cases in whlch the polarity of the polien grain can be deteritined at this stage, the generative cell 1. ususlly cut off agalnet the alstal or proxinal sice of the grain (tha cour, 1949).

Soon after the two celli are formed, the cytoplasm of the vegetat1ve cell develops any vacuoles as shown in fige. 3 and 4 (phase). This Inely vacuolate atage is loot a chort tine after 
the generative cell 11 es within the vegetative (PLATE 47, PIg. 1). A similar vacuolate stage has been recorded in Pseudowlutera (Sampson, 1963) and in Bellsohmledie tawa (Roper, pers. comm.). During maturation of the grain the cytoplasm of the generative cell becomes congpicuously more hyaline than that of the vegetative cell (PLATE 47, 18.2 ). In contrast to Hearcarra the generative cell does not become spherlcal, but retalns to some extent 1 ts orlginal shape. Pollen 1s shed in elther the two or the threecelled condition. When the generative cell does divide berore it Is shed from the anther, this diviaion occurs within a day or two of dehircence. A pollen grain in which the generative cell ig at telophase is 111ustrated in PLATS 48, P1g. 1. The vegetative nucleus is in a afferent plane of focus. F1g. 2 1Ilustrates a three celled grain and the two male cells are shown lying above the vegetative nucleus. They resemble the vegetative cell in thelr apindle shape and hyaline cytoplasm.

At dehiscence, the endothecium 18 radially thickened and the aldale wall layera are flattened and erushed (PLATE 41, P1g. 2). The semi introrse-latrorse dehlscence occurs by the outward opening, beginning at the base, and upward bending of an elliptical red coloured part of the anther wall which 1 s hinged at the top (frontisplece; PLATE 5, flg. 4). A conslaerable amount of pollen adherg to the inside of this $\mathrm{rap}$, as can be seen in the upper two carpellate flowers shown in PLATR 5, $1 \mathrm{gg}$. 1, from whence $1 t$ would be readily brushed off by v1siting 1nsects. Dehiscence 
occura by the separation of cells around the edges of the flap which form a stomiun-like region. Thus in transverse section, four stomium-11ke reglons of ama.11 unthlekened cells can be seen in indehi øced stamens (PLATR 39, 12. 4). Discusston

żtgmeng

As outlined In Chapter 2, the stamens of Hedrearye and Laurel1a differ markediy in appearence and structure, but the stament of Peumue and Mominla provlde a $11 \mathrm{nk}$ between the Atherospermoldea and Monimioldeas. The stamens of the Atherospermoldeae are obviously closely related to those of the Lauraceae. There 1. however greater variation in atamen structure in the Lauracese In that there may be 2 pollen aace (e.8. Lawrus), as in probebly all of the Atherospermoldeae or 4 pollen sacs. In the latter case the sacs are elther at the same level with each pair of sacs dehiscing by a single valvular lap, as in Bellechmiedia (Roper, pers, comm,), or one pals of sacs is situated above the other pair and each sac dehisees separately, as in Umbeliularis. In Cinnamoqum there are transition forms between two and four chambered anthers (Kasaplig11). In vlew of the predominantly Iour chamberea atamens in anglosperma It seens logical to assume that the stamens with 2 pollen sacs represent a derived condition. Thus Kasapligil (1950) maintained that the stamen of Laurus with 1ts two pollen sacs had been derived from a four celled type of anther and in aupport of this view mentioned the presence of 
teratological stamens with an 1neomplete alaphragin in each sac. The stamen of Belischmiedis with 1ts 4 chambers which dehisce by means of only 2 valves, might well represent an intermediate atage In the derivation of the 2 chambered laumaceous atamen. I did not find any ontogenetical, morphologleal or teratological indication In Laure 2 is to suggest that the anther had once been four chambered. The second type of four chambered stamens in the Laturaceae are nore difficult to interpret. Some workers have suggested that the four chambers may have been derived from a otamen such a that of Latuxus by the development of a transverse median partition In each of the two sace. Kasapl1g12 commented on the frequent dichotomies at the t1p of the median vascular strand and at the t1p of lateral fllament traces in Umbellularia. He suggested that such dichotomies may indieate that this genus once had four terminal mierosporangla. This seems unduly speculat 1ve to the writer, at least with reapect to the forking of the median strand, as many stamens have this feature irrespectIve of the number or the location of pollen sacs e.g. some stamens of Hearcarys. Rasapligs.l added that the dichotonies "could be interpreted in accordance with W12son's (1937) theory that stamens are derived from dichotomoug branch systems which had terminal sporangla". He did not however interpret alchotomies within the staminal glands in accord with the Telome theory sinee he considered the glands had arisen de novg. It seens $21 k e 1 \mathrm{y}$ that the primitive 'Atherospernoldeae-Moninloideae' stamen had 
94,

Sour pollen saes, but it 18 debatable whether such a stamen had 2 fllament and staminal appendages, as apparently suggested by Mones et al. (see Chagter 2). The Sllament-leas, eglandular stamen of Hedvenxwa could conceivably have been alrectzy derived from the apparentIy primitive leaf-11ke ranalean ateaens. Tagetum

Hedycarye and Laurel1a resemble Cresuthn (Sastr1, 1962) and Be11schmitedia tava (pers, comm. Roper) In having a secretory tepetum but alfer from the other genera of Lauraceae so far studied, which have the periplasmodial type (Sastri, 1963). Sastri (1963) who made a few observations on microsporogenesis in Atheropperma found that this genus, which as I have stated, appears to be closely related to Laurelis, had the perlplasmodial type of tapetum. I therefore conclude that the two types of tapetum do not have great taxonomic significance ot least within the Mondmiacea and Lauracene. Cxtokineg1:

Hedrearya resembles all nembers of the Lauraceae so far studied in having auceessive cytorinesis by cell-plate formation (Sestri, 1963).

In $\nabla$ iew of the discovery of an apparentiy new type of eytokinesid in Loure21a, it would seem desirable that I should now summarize the types of cytokinesie which have been recorded in anglosperms. Perlaseng and Swamy. (1959) have pointed out that there has been some anbiguity in the use of the terms "guccessive" 
and "glmultaneous" and conslder these terme should deslgnate not merely a teaporal relationship but two different cytological processes. They atate that the 1aportant feature 1 whether or not the walls are instiated by a centrifugally spreading cell-plate or by a centripetel conetriction furrow. Although centrifugal cell-plate formation usually occurs in a successive manner with the flrst wall belng formed at the end of melosis I and although centripetal cytoplasmic constriction usually occurs in a simultaneous manner, there are except1ons. I have criticlsed the choice of the terme "successive" and "sinultaneous" and suggeated that pollen tetrads shoula be described as belng formed by "suecessive" or "simultaneoug", "centrifugal cell plateg" or "centripetal constrietion furrow" (Sampson, 1963). The following types of eytokinesis have been recorded:(1) Cytokinesis by successive centrifugal cell plates deposited at the end of melosis I and II, as in Hedycarya and many other plants (Maheahwar1, 1950).

(2) a. Cytokinesis by sinultaneous centripetal constriction furrows at the end of meloels II, as in Mlcotseng and many other plants (Moheshward, 1950).

b. A ranor variant of this type occura when one of the furrows appears at the periphery of the pollen mother cell at the end of melosis I. It does not however reach the centre of the mother cell unt11 the second furrow (which appeare at the end of meiosis II) does. Quartet fomation is therefore slmultaneous. 
Hagnolia kobus 1s an example of this type (Stouat, 1960).

The above two tyges are by far the commoneat.

(3) Cytokinesis by means of slmultaneous centrifugal cell plates which develop at the end of melosis II, as in Helleborus (Vaterkeyn, 1962), Illicium, Schisandre and Kadsure (Hayashi, 1960, 1965).

(4) Cytokinesis by means of succesalve centripetal constriction furrows as in some of the Annonaceae (see Perlasamy and Swamy, 1959). (5) Cytokinesls by means of almultaneous constriction furrows, but a transient cell-plate or cell-plate precureor 1s present at the end of meiosis I. This has been recorded in ingogynum (Swany, 1952) and Pseudorlntera (Sampson, 1963) of the Winterraceae and 1n Magnolia (Farr, 1918; Hayash1, 1960). In Helleborus, in which cytokinesis occurs sinultaneously at the end of getosis II by cell-plate formation, Waterikeyn (1962) found that the equator of the spindle was invaded by basophille granules during interkinesis. These were grouped into an equatorial plate which Waterkeyn considered to be a mitochondrial plate. It 1 soasible that Zygegrnum, Pseudowintere and Hagnolla might therefore have such mitochonartal plates rather than tranelent cell-plates or cell-plate precursors, unless of course the mitochondrial plate 1tself represents a eell-plato precursor.

(6) The type recorded for Laurelia in which a centripetal fuxrow, Instiated at the end of melosis I, reaches the centre of the mother cell at the same time (as far as can be ascertained) as centrifugal cell-platea, which are generally oriented at right angles to the 
furrow. These cell-plates are inftiated at the end of meiosia II.

It is posalble that oytokineals in tramelia is merely of the "2५." type deseribed above. For, according to Waterkeyn (1962) who studied mierosporogenesis in Helzebosus by means of ordinary 11 ght and Pluoreseence mieroscopy as well as by electron mleroscopy, cell plate formation and centripetal furrowing may not be mut ually exclusive. He quoted West (1930) who found in Viola that at the end of me10els II. "In pollen mother-cells in which furrowing has begun, dellcate cell-plates are seen at the equator of the spindles ..... These probably asalst in the formation of the tetrad wall, although they appear to be merely evanescent structures." Waterkeyn Sound that in Helleborus the grenulose cell plates which form at the end of melosid II are transformed into callose walls which become enelosecentripetally by less dense callose deposits. It would seern possible to me that this phenonenon may occur in other plants which have been described as having cytoikinesis by means of simultaneous centripetal constriction furrows when Waterkeyn's methods are used.

It 1s aurprising that Atherospersa should have cytokinesis of the successive type (Sastri, 1963) and this demonstretes that the two basle types of eytokineals do not have taxonomic value in the Monimiacere.

\section{Migrognoger}

Hedrcasyg 18 apperently the only genus within the Monlmiaceae to have polien in permanent tetrads (Honey et al., 1950). It 
seems obvious that the permanent tetrad condition has evolved separately by parallel evolution in view of $1 \mathrm{ts}$ preaence in a number of fam1lies which are not closely related e.g. Ninteracene and some of the Droseracea,. Typhnceae, Ericacene, Apocynaceae, Asclepiadecere, Juneaceas and orchidaceae (Kaheshwari, 1950).

Peranently unlted tetrads have been recorded withis thes woody Ranales 1 in Hedycams, the 6 genera of the Winteraceae (Ba1ley and Nast, 1945), 11 geners of Annonaceae (Cannight, 1963) and in Lactors of the Lactordaceae - a monotyple family which Carlquist (1964) conslaers 1a of unquestionably annonalian afrin1t1es. Although it 1 s possible that all of these genera have Inherited the permanent tetrad condition fron a single ranalean group of ancestore, the Winteraceae doer not appear to be closely related to the other fanlles (Ba1ley and Nast, 1945; Money et al., 1950). According to Carlquist (1964) the permanently united tetrads of Hedyearse on the one hand and the Annonaceae and Lactorts on the other are "undoubtediy parallellems" desplte his viev that the Monimiacear was one or the families which had "the greategt constellation of morphological and anatonical featurea like those of Lactoris".

In contrast to Ledyearys, the generative eell is cut off against the proximal (1nternal) comer of the grain in Pseudewhtere (Sanpson, 1963) and zNrogrnum (Swamy, 1952). Th1s feature has not been invest1gated in the other ranalean genera with permanent tetrads. Hedrearye resembles Canangt of the 
99

Annonsceae (Porlasany and Swany, 1959), Degenerda (Swamy, 1949), Austrobalieva (Balley and Swamy, 1949) and at least some of the Uagnollaceae (Swamy, 1952) In having the generative cell cut off against the distal side of the grain. 
CHAPTER 5

\section{ONTOAFN, STRUCFUES, FUNCTION AND MORPHOLOATCAL MANURE OF THE STAMINL APPENOAGES OF LA URETIA}

The vascularization of mature ataminal appendages of Laurelia has already been descrbed and compared with some other membere of the Laurales (Chapter 2). Some theorles as to the morphologIcal nature of these appendages have been briefly mentioned. Ontogenve structure and function

Fach gland arlses laterally a short distance above the base of the stamen when it is about $230 \mu \mathrm{hlgh}$. At this stage 2-3 wall leyers have been formed in the anther and sporogenous cells are dividing vigorously. The gland is initiated by anticinal elongation followed by antlelinal division of a group of surface cells simultaneourly with the anticlinal elongation followed by anticlinal and periclinal division of cells in the subjacent hypodermal layer, near the base of the Pllament (PLATE 29, P1g. 2). Bome periclinal and anticlinal divisions then occur in the subhypodermal layer beneath. An anticlinally alviding cell of this layer can be seen in PLITR 30, f1g. 1. The young gland is now a ama11 mound (PLATE 27, IIg. 19) which Increases in size by general cell enlargement and division, predominantly in anticlinal and periclinal planes. The glands therefore originate in a manner simllar to stamens and other Ploral appendages.

The primordium enlarges as a mound of Increasing diameter 
(PLATE 27. I1gs. 20 and 21) which is blunter than a stamen primoralum. Cell division is general throughout the primordium and no apleal or subaplcal inltials were observed, presumably because growth 1: so multi-directional. Cell divial on becomes nost frequent arouna the periphery of the primorasum and infrequent near the base, where the cells become vacuolate (PLATE 30, 118. 2). Eventualiy a stalked mushroom-ehaped glanâ is formed. A surface cell "s" is undergoing perielinal division and pairs of cells have been formed from recent periclinal divislone of surface cells, in the rigure. This unusual feature of perlelinally alvialng surface cells in a flower (Tucker, 1961) was encountered In one other floral part (see on). Procamblum has now formed In the base of the gland but is not visible in the section 11lustrated, which is non median. It is visible in the transverse section of glands at this ame stage of development (FLATE 31, flg. 1). At this stage the pollen mother cells are at prophase I of melosis. When the uninucleate pollen grains are dividing in the anthere, a few cells were still dividing within the glands, in addition to those cells which were inltiating vaseular tissue. By thia time the base of the stamen fliment has elongated and glands were now Inserted some distance above the base of the stamen. When the anthers contalned mature pollen grains, cell division had ceased within the glands (PLATE 31, f1g. 2). The epldermal and subepldermal cells of the inner face of the gland (to which the stalk is attached) are large vacuolate cells and contain 
depositz of a tannin-1ike nature. In contrast, the eplderaal celle of the outer face of the gland are smaller, lese vacuolate and lack the tannin deposits. Th1s 1s correlated with the fact that only the outer face of the gland secretes nectar. Each of the epldermald of the outer face contains several spherical incluslons which at this stage are up to a third of the diameter of an epldernal cell nucleus. They stain dark blue with haematoxylin. As such 1nelusions do not occur elsewhere in the flower It would seem that they are in some way assoclated with nectar secretion. Beneath this epldermis are several layers of cells which do not contain the inclusions. In contrast to the subepldernal layers beneath the inner face of the gland, these layers have a dense eytoplasm.

A stamen from an open flower was sectloned in whlch the gland had been secreting nectar. It was found that aany of the spherloal inclusions in the epldermis of the outer face were as large as the epldernal nuclel. The largest inelual ans atalned a light red colour with haemstoxylin but some of the snall inclusions stalned the daric blue colour of earlier stages. As there were Intermediate forms in size and colour it is presumed that there are present different stages in the development of a single type of inclusion. The subepidernal layere of the secreting face no longer have a dense cytoplasm but instead have usually a single large vacuole or in some cases several large vacuoles. The nuclel of these epldemals and subepldermals are well developed 
and show no signs of degeneration, with the exception of the nuclel of some alsintegrating epldernal cells (see on). I. would think it ilkely that the vacuoles in the subepldernal layers contain the sugar solution which is secreted. At the earlier stage in which the se cells had a dense cytoplasm, etaining with lodine revealed that they were packed with atarch graine. Eplaermal celle of the outer face hovever, contained few if any starch grains; what few starch grains they possessed nay heve escaped from subepidermal cella during the preparation of the sections. Hydrolysis of the starch before secretion begins would presumably be responsible for the production of a sugar solution in the vacuoles. It is problematical juat what role the analler vacuoles and large inclusions of the epidenal cells play in the secretion of nectar. According to Isau (1953) closely packed thin walled cells beneath the epldernis and rich in cytoplasm constitute, together with the epidermis, the secreting t1seue in many nectaries. However according to Fames (1961) it is only rarely that the epidermis overlying the sibepldemal secretory t1ssue is 1 t self secretory.

Kasap11g11 refuted Daunan's (1931) suggestion that secretion of nectar from the glands of Laurus occurred through the cell waIl of the epidermis and thin cuticle. He found that in Unbelluiaria, and by Implication in Laurus too, although this 1 s not definitely stated, "the cuticle breaks down and the epldermis disintegrates around the glandular surface ... jugt before the opening of the 
Plowers. Apparently the secretion occurs through the Intercellular spaces of the ground tissue and the breakdown of the epicermal cells facilitates the ejection of the sticky aecretion to the glandular surface." He did not describe the structure of cello whin the gland nor suggest from what cells nectar wight be secreted. Now in Laurel1a, as a concomitant of nectar secretion, the cuticle of the secreting face is ruptured in places and some of the epidermal cells are damaged, apparentiy by Internal pressure exerted by the escaplng nectar. As 1 s general for nectaries according to Perctval (1961), there 1 s no secretion of nectar in Laurelia before the beginning of anthesis. Secretion of nectar 1s therefore quite siailar in Lamelia and Jmbeliularia elthough it begine later in Laurelia and the epldermis $1 \mathrm{~s}$ not as extensively danaged during the process of secretion.

As in Umbelinlaria, the mature giand of Laurelis containod aplrally thickencd tracheary elements. No sleve tubes and companion cells could be found withln the vascular tissue which st112 contalned many procambial cells. Kasapl1g1. too was unable to rind derlatte phloen elements in the glands of Unbellularfa. It seens therefore that sugars enter the gland by means of relatively undeferentiated tisaue, as in the ovules of many plants Including Ledyearrs and Laurejia (at least up to the fertilization atage).

When the flowers open, the nectar is visible as a colourless 11 quid which glves a gliatening appearance to the outer faces of 


\section{5}

the glands (frontieplece). Nectar runs down from the glands and accumulates at the bottom of the flover as a result of continuing secretion. Large numbers of bees and blowelles were seen to visit flowers to obtain nectar from trees at Lake Ponui as well a amall flightless animals e.8. wites. It 1 s doubtful to what extent the red colour of part of the anthere attracts the Insects to the nectar, for they are not in general sensitive to the hlgher wave-lengths of the spectrum, which includes red. However some red coloured flowers do attract bees by virtue of the large amount of whra-violet 11 ght which they reflect (w1 gglesworth, 1964). The blowfly Galliphore visited flowers of Laurelis and this insect 1 s sensit1ve to red light (Wigglesworth, 1964). In any case the 1nsects would be attracted to sone extent by the yellow colour of the glands and by the taste of the nectar 1teelf, once they had allghted on the flower. The flowers are odourless to huans and although they may not be odourless to bees, the olfactory aculty of man and bees is ald to be quite similar (W1gglesworth, 1964). The glands of any functional stamens of carpellate fowers also secrete nectar in enough quantitles to attract insects to such flowers. Although therefore the functional stamens of carpellate flowers may not be of great importance in supplying auch pollen to the carpels in comparison to the pollen supplied by male flowers, they are of great 1mportance in attracting pollen-carrylng insects to the carpellate flower, thereby effecting pollination. Th1s may 
explain why the few functional stamens, whlch are present on so many carpellate flowers, have not disappeared during evolution. It should however be borne in mind that Irlmenia and Plptocalyx of the Trimenlaceae, which 18 closely related to the Honimiacea, also have some flowers which are transitional from bisexual to unisexual, but these genera lack staminal appendages (Money et al.). Because of the large number of ale plowers in close proximity to carpellate flowers on the same tree, self fert1lization would be a much comoner occurrence than cross fertillzation, unless wone type of self incompatibli1ty mechanlam were operating. The nectar had a sweet taste and tests showed that it was predominantiy sucrose, with perhaps traces of raffinose (see Appendix). It would be interesting if traces of raffinose were In fact present, in view of Percival's (1961) conclusion, after studylng the nectar of 889 species of anglosperms, that "a pure sucrose nectar, with the single oligosaccharide raffinose could almost be safely sald to be Ranalean". She did not however examine nectar from any plants in the nore primitive woody Ranales but rather 37 species within the Helleboracese, Ranunculacese and Berberdaceae. Morpholozical nature

The following theorles have been proposed to explain the morphological nature of the staminal appendages of certain members of the Laurales (zensu Hutchinson).

(1) Kasaplig12 and cerlier Mez (1889) considered that the 
appendages had arisen de novo to serve as nectaries. Daumann (1931) suggested that this was accomplished by partial splitting of the staminal primordium into three parts of which the two lateral ones became nectaries.

(2) Both Eichler (1878) and Engler (1926) interpreted the appendages as stipular formations on the stamens and Gluck (1919) Interpreted them as stipular glands.

(3) Money et al. and a numer of earlier workers (e1ted in Kasaplig11) Interpreted each appendage as a staminode. Thus according to Honey et al. each functional stamen of Laurella. for example, bears two "assoclated staminodes". Fanes (1961) considered the appendages to be staminodal in origin and stated that they had arisen by fasciculation (1.e. aggregation into groups) followed by transformation (1.e. ster111zation) of part of the fascicle into nectaries. He thought that each gland might sometimes represent more than one staminode and stated "each stamer, with 1ts associated nectaries, represents a faccicle of three stamens, probably five in those genera where the stamen base has Iive bunales".

Bach of the above theoriea wi1l now be considered in deta11.

(1) De_novo theory

Kasapligil put forward the following axguments in support of this theory. (a) He believed the glands could not be homologized with stamens or staminodes $\mathrm{from}$ an ontogenetic point of view because the stament and stamlnodes are produced by the floral apex, 
"whereas the staminal glands arise from 'lateral meristenatic reglons" of the atameng". This argunent does not seen valid to the writer. As Eames (1961) polnted out, sone lauraceous genere have the "attachaent of nectaries on the receptacle free from the stamen". Examples of this feature in the Monlmiaceae are Atherosperma and Drradodephne (Money et al., 1950) and in the Lauraceae Belizechmiedia tave in which Roper (pers. comm.) found that the appendages were proâued by the florel apex. It could therefore be argued that with further evolution the appendages became attached to the staminal rlament, as in Leurus (PLATE 31, 118. 3) and Laure119. Note how in the stamen 111ustrated (as In some stamens of Laurel1a - see PLATE 9, fig. 2) the fllament 1s broader below the glande than it is above them. This suggests the basal parts of the appendages may be fused (in the phylogenetic rather than ontogenetie sense) to the staminal fliament. The reverse argument $*$ - that the appendages have arisen on the stamen 11lament but during the evolution of sone genera have migrated onto the receptacle - does not seem so convincing in view of the general tendency of Ploral evolution to be in the alrection of aggregation rather than separation of parts. In Laurelia, at least, the appendages are 1nitiated in a manner similar to that of stamens and staninodes. Although Kasapligil does not give a detailed account of the initiation of the glands in Uabeliulaxia, froth his description and 11lustration initiation could well be

- Not put forward by Kasap11g11, who seemed unaware that some lauraceous genera have the appendages inserted on the receptacle. 
sinilar to that in Laurelie

(b) Kasapligil's second argument was that "evidence Prom vascular anatomy" suggests the de nove origin of the appendages. However he did not give detalls of this evidence beyond atating that the giand does "not exhibit a constant pattern", giving detalis of the vaxiation and comenting on the "profusely ratifled vasculation of these oxgans". Eares (1961) attacked this theory and reasoned that the complex vascular structure within the aecretory region had developed almulaneously with the nectar secreting function. He added that "the origin and course of the vascular supply $2 \mathrm{~s}$ the same as that of the stamens".

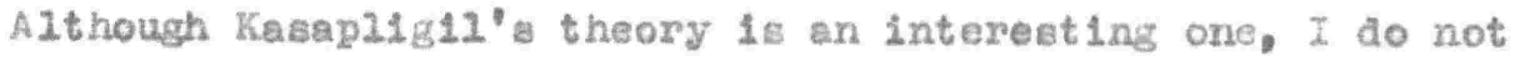
consider there is definite evidence to support it, as indicated above. A number of the Latarales have ataminal glands which do not function as nectaries, including Beilschmiedia tawe (Roper, pers. coun.) and Hortonta of the Monjalaceae (Koney et al.). Honey et a.., state that "at times" the appendages assure a glandular function but do not clte examples. If Kaaplig1's theory is correot, we must aseume that the conslderable number of lauraceous gener, in which the appendages do not function as nectaries, once had this function which has been subsequentiy Iost, leaving vestigial non-functional nectary. This does not seea very $21 \mathrm{kely}$ to the writer. It has been shown in a number of cases that nectaries have been modifled from an organ which has lost 1t: original function, although the latter port of Eames's(1961) 
gtatement that all ploral nectartes are elther "localized areas where nectar is secreted, or organs transformed from their original form and function", may be an overetatement.

\section{(2) StLpuIsistheory}

This theory has not recelved support in recent times, 15 only on account of the absence of atipules on lauraceous leaves, and does not seen to merlt serlous conslderation. Kasaplig11 noted for the Lauraceae that "the nodal anatomy of the follage leaves and of the stamens is unilacunar and the leaves are entire; therefore, the occurrence of stipules would not be expected (cr. Sinnott and Bailey, 1914)" The Monimiaceae also have unllacunar nodal anatomy (Money et al.).

(3) Stgringàa_theory

This theory seems the most attractive one and I will consider it uncier severad sub-heading

(1) Vascularization

Eames' views that vascularization supports the staminodal origin of the appendages have already been mentioned (see above). In their morphological survey of the Honimlaceae, honey et al. concluded "the vascularization of the three assoeiated appendages provides no cogent evidence for interpreting the two sterile members as 2obes, st1pule-like parte or glandular outgrowths of the fertile alcrosporophyll. The velns of the staminodes(i) (regardese of the degree of concrescence of the three appendages)

(5) Honey et al., are applylng this tern to the staminal appendages. 


\section{1}

usually do not arlec as branches of the vascular strand of the fertile stamen, but extend independently and more or less extensively downward into the torus. Although the vascular etrands of the ataminodes comonly arise as branches of a trifuresting toral bunde, this is not invariably the case. Not infrequently the vascular strand of a staminode arises from an independent part of the varcular system of the receptacle." There is considerable variation in the vascularization of stamens and their appendages even within a single species, as described for Laurus and Umbellulaxia (Kasaplig12, 1951) and Laurelia (Chapter 2). However it would seem that basically the stamens and appendagea have a sinilar vascularization, it belng assumed that the dendritic pattern in the appendages is a recent development, and any fusion between staminal traces and appendages traces, is a rellection of the phylogenetic fusion of the two types of organs.

\section{(11) Teratologsy}

Kasaplig11 (1951) made mention of the alscovery by some earlier woricers of occaslonal teratologieal staminal glands, within some lauraceous genera, which resembled anthers in the presence of "sterile or fertile thecre which open by means of valves". Eames (1961) also mentioned this phenomenon and considered it to be evidence supporting the staminal origin of the nectaries. In my oplnion it is dangerous to read too much Into 'hybrid' structures whlch are apparently produced by occasional ontogenet1c aberrations. When however more or less intermediate 
forms occur between two hypothet1cal structures with regularity, far stronger evidence 1 provided for comon or derived origins. For example, in the carpellate nower of Laturelia, the more extermaly situated staminodes regularly bear appendages which show varying degrees of reduction in alze and vasulation, compared With those of the functional stamens. This provides strong evidence that the more reduced internaliy situated otaminodes (PLATE 9, 11g8. 13-15) have each been derived from a stamen and 1ts associated appendages. If then these appendages represent ataminodes, the apparently simple staminodes within the carpellate flower are "second generat1on" staminodes.

\section{(111) horphological resemblances}

There 18 some external resemblance between appendages and stasens in sone lauraceous genera, as Eames (1961) noted when descrlbing the rllament-11ke stalk and "more or less" anther shaped tip of the staminal appendage of Perseg. In the New Zealand Lltses calloars (Lauraceae) too, there 1s a considerable resemblance between the stamens and appendages. It 1 s of interest that Laure 119 and some other lauralean genera have stamens, staminal appendages and ataminodes within a single Plower (PLATE 5, Ilg. 5). Some resemblance can be observed between the staminal glana and the uppermost portion (presumed to be the ster111zed anther) of reduced staminodes. There is also similarity between the stalk

\footnotetext{
- I.e. those closest to the functional stamen(s) when the latter are present.
} 
of the gland and the lower flament-like part of the staminode. An ontogenetic resemblance was also found between the two structures In that the upper part of the staminode has surface cells on the flattened adaxial face which undergo perlelinel divisions as found elsewhere in the slower of Laurelia only in the staminal gland. A median longisection of such a staminode is lilustrated in PLATE 32, I1g. 1; an enlarged part of the upper portion of a somewhat younger staminode 1 s shown in $14 \mathrm{~g} .2$, In which at "e" for example, two cells can be seen which have resulted from a recent periclinal divieion of an adaxial eplaermal cell.

Conclusions

As indicated in the foregoing. I consider there is strong evidence for the staminodal origin of the appendagea. Before any final conclusions are made, it is desirable that a study be made of the comparative structure and ontogeny of the staminal appendages of all membere of the Lauralea which possess them.

A quest ion requiring explanation 1s, why are there invariably two appendage associated with each stamen? Beyond stating that the association arose by fascleulation and partial sterilization of stamens, Eames (1961) gave no explanation for this 2:1 rat10. Now in some genera e.g. Umbellularia, not all of the stamens beax appendages. In this genus the two outer whorls usualiy lack then, in contrast to the third whorl. In view of the not uncommon presence of transitional forme between glandular and eglandular stamens in the outer whorls of Umbellularia 
(and Laurus), Karapl1 11 coneluded 20 glea 21 y enough, that the outer staninal whorls were at one tine glancular. The $2: 1$ ratio of appendages: stamens would be met if an ancestral lauraceous Plower had:-

c1ther - succeselve whorls of etamens in which ome whorl had twice a many stamens as the next and so on - and the fomaer whorl became stemilized and assoclated with the latter;

cr - eacil whorl had the same number of stamens and two whorls became sterilized and assoclated with every whorl which romalned sunct ional.

The second condition seems the more likely of the two alternatlves, (although these are by no means the only alternatives), In $v$ lew of the fact that sany lauraceous genera have flowers with whorled stamens with the same number of stamene per whorl, e.B. Lauxus, Umbelfular1a (Kasap11g11, 1951). Although Laurel1a has ap1rally arranged atamens, the closely related Dormphora has whorled stamens of three per whorl. If the whorled arrangentent coss represent the ancestral condition, then the spirel armangement of atamens in Lumrelia would be a derlved condition, which is unusual in that the splral arrangement of Moral parts is generally regarded as a primitive condition (e.8. Thome, 1963; Hutehinson, 1959).

\section{Addendum}

In a book by curt1s (1967) whlch has recently become ava1lable, It 1 stated that the staminal appendages function as nectaries in Atherosperma. They therefore resemble those of Laurelia in this respect. 


\section{CHAPTER 6}

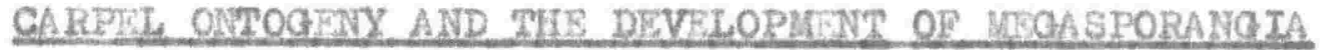

\section{AND FEMALE GAIETO WXYSE}

\section{Garpez ontogeny}

The floral aplees of Laurelig and Hedycarya are slightly convex mounds of roughly $200 \mu$ and $300 \mu$ dilmeter respectively, when the firat carpels are inltiated in spiral centripetal aucesalon. A carpel is lnttated by localized divisione at the periphery of the meristem, in a manner almilar to that described for stamens (Chapter 4). Each carpel becomes a hemispherical mound (PLATE 48, fig. 3, carpel at left) by general cell enlargement and division within the primordium. Hecycarya

As in the young stamen primordiur, the young carpel primoralum consists of relatively alserete vertical flies of cells, because in general the subprotodermal cells near the tip of the primoralua divide in perlclinal and anticlinal planes, whereas those on the flanks and in the central axis divide mainly in horizontal planes. When the carpel is $55 \mathrm{hlgh}$, there $1 \mathrm{~s}$ a small adaxial protuberance near the base of the primordsum. This protuberance 1 s formed by localized antlclinal division and antielinal elongation of a few protodermal and subprotodernal cells and marks the appearance of the adaxial ifp or "Querzone" or "cross zone", typleal of peltate carpels (Troll, 1933, 1939). At this stage (not 12lustrated) 
a periclinally and anticlinally alviaing subprotodermal initial had recently developed within the Querzone and had undergone its Ilrst periclinal division. Recent derivatives of this cell also divide periclinally and anticlinally and the adaxial $11 p$ increases In size (compare fig. 2, PLITE 23 and f19. 1. PLATE 24). Between this intial and the perielinaliy and antielinally aivialng subprotodermal cells at the apex of the carpel, arlse two arcs of subsurface initialø, as in Pseucorlnterg (Sampson, 1963) and Deings winteri (Tucker, 1959). They form, together with ant 1elinally dividing surface initlals directly above them, a continuous rim of meristematic t1ssue which forms the sides of a tilted bowl (PLATE 48, r1g. 3, carpelis at right and centre). When the carpel is approximately $300 \mu \mathrm{hlgh}$ ( $11 \mathrm{~g} \cdot 4$ ) procamblum of the dorsal otrand has formed in the lower two-thlrds of the carpel (PLATE 24, $\mathrm{fIg} .2$ ). The aperture or cleft of the carpel soon reaches its maximum size (PLATE 48, f1g. 4) as in Drimys wintexi (Tucker, 1959) and Pseudowntera. It resembles thene latter plants in that it remains the same size during further development (11ge. 5, 6 and 7). Shortly before anthesis the carpel is closed by appression of the sides of the cleft, leaving a vertical ine on the slae of the carpel where once it was open (f1g. 8, between $x$ and $y$ ). Most of the locule 1 s formed below the cleft, by intercalary growth of a cylindrieal nature. In longitudinal sections ( $12 g 8.50,6 b$ ) It can be seen that the locule does not reach the bace of the carpel and this lowermost solld stipe 
portion is a result of basal growth. At the stage shown in $6 \mathrm{~b}$, the ovule ("ov") has been formed.

The stigmatic region in Hedycarys arisee by the growth of solid tissue above the eleft. Thie tissue is morphologically the upperaost part of the orlginal abaxial carpel protuberance. This 1 a considerable contrast to the primitive conduplicate ranalean campls such as Degeneria (Swamy, 1949) and Delavs lanceolats (Tucker and Gifford, 1966b), which poseess long clefts, and a contrast also to the nore nodilled conduplicate carpels such as those of Pseudowintera (Sampson, 1963) and Drinys winterd (Tucker, 1959). In these plante the st1gmat1c region arises by the formation of receptive tissue around the outside of the eleft thereby forming the eo-called "otigmatic erests" (see Balley and Swany, 1951). Durlng growth of the st1gmat10 region in Hedycarra cell aiviaion is not confined to the protodermal and apleal subprotodermal layers, desplte the fact that the subjacent tissue comprises large vacuolate cells from an early stage of development onwards (PIATE 24, f1g. 2). DIVIsions were frequent within the vacuolate tisave e.g. the anaphese division flgure in the cell "m" There is thus a resemblance to the large vacuolate cells of the lower part of the florel apex (see Chapter 3 ). Transverge sections of a carpel, slightly older than the one shown in PLATE 48, P1g. 6, are 111ustrated in PLATSS 50 and 51. The sections are at successive levelo beginning near the apex. Figures 1-3 of PLATB 50 11lustrate sections through the stigmatic- 
stylar regton and $1 t$ can be seen that the tissue is a sol1d eylinder, lacking a gtylar canal. F1gs. 4 and 5 or PLATE 50 and IIG. 1, PLATE 51 are seetion through the cleft. The eleft widens 1nterna1ly near its base to form the uppermost part of the locule (11g. 1, PLATE 51). F1gs. 2-4 show sections through the ovular region. Note the presence of the ventral (ovule) bundle in figs. 3 and 4 and the megagore mother cell at prophase I in f1g. 4.

There is no locallzed terminal stigma but instead the uppermost part of the carpel consists of a knobbly mass of globose projectlons which serve as pollen traps. This reglon occuples nore than half the total length of the carpel (PLATE $48, f 1 g .8$ ). The projections are formed by the maturation (enlargement) of apherloal secretory cells and some tannin-filled cells which are stituated close to the surface (PLATE 47, 11g. 3). No conparable type of stigna has been described for a ranalean genus and It Is of Interest that during the coures of evclution of Hearcarya, the large Becretory cells, so prevalent in the woody Ranales (see Money et al.), have been ut111zed to form what are apparently pollen traps. The stignat1c surface consfsts of unlcellular receptive trichomes (1.6. Etlgnatic pap1liae) of a different appearance from epldemal cells investing the reat of the carpel. S1m1lar, but longer receptive trichomes occur in Laurelia. A few week before pollination, the carpel of Hedycarva undergoes a conslderable increase in size, after it has asauned 1ts more 
or less mature shape. Thle can be seen by comparing the carpels shown in $11 \mathrm{~g} .4$. PIATE 47.

The solid sterile carpels of Hedvcarya lack the adexial meristeme and develop a solld Ilnger-like protuberances which possess trichones before these are present on nornal eargel prinordia. Wach such sterile carpel 1s vasculartzed by a aingle strand which rume medianly through the structure and the strand. branches near $1 \mathrm{tg}$ tID (PIATE 10, flg. 7). The least reduced solid ster1le carpels have a teminal atlgmatlc region which to similar to that of nomal carpela, though more reduced. Horphoiogically each sterile solla caryel seems to represent a nornal carpel, shorn of 1tz "querzone".

\section{Laure 11 s}

Barly carpel growth resemblea that descrlbed for Hedrcary, athough the young carpel prinorala of Inurelia have a more finger11ke shape and the adaxial 11p (cross zone) 1s not present unt 11 carpels are gbout $90 \mathrm{hlgh}$. A carpel $150 \mathrm{high}$ is whown in flg. 1, PLATE 52, w1th an as yet weakly developed adaxial mexistem. A later stage is shown in 118.2 in which the procasbitan of the dorsal strand has formed in the lower three-quarters of the abaxial side of the carpel (not clearly seen in the section 117ustrated). Comparison with an approxinately conparable stage in Hedyearya (PLATE 24, IIB. 2) reveals that the central eella of the abaxial lobe are not as vacuolate in Laurelia. Note how the cello of this lobe are in relatively alscrete vertical rows. As in 
Hedzcarra cell alviaion occurs throughout the carpel at this stage. An Important contrast to carpel development in Hedrearva Is that the cleft continues to elongate for a considerable time arter 1ta formation (PLATE 49). Tuciker and alford (1966b) found similar differences in carpel growth between Drimse winterd with 1t: short cleft and D. Lanceolatg with 1 ts relatively long cleft. The eleft deepens by accelerated cell division at the ventral margins of a horseahoe-shaped prinordiun, as seen in a transection through the cleft. As in Hedvcarve, the locule develops below the cleft by growth of a hollow cylindrical nature and the lowermost solla part of the carpel (see flg. 3. PLATE 49) 18 a result of basal growth. As in Heavearye too, the atigmat1c region arises by growth of solid tissue above the cleft. The stigma 1e less extensive than in Hediscaxya although receptive trichomes cover all of the earpel above the eleft (fig. 5).

PLATES 53 and 54 111ustrate transverse sections of a carpel at successive levela beginning at the apex. The carpel is at about the stage of development of the one 11Lustrated in f1g. 4 , PIATE 49. F1gs. 1 and 2 of PLATE 53 12lustrate sectione through the stigmat1c-stylar region and f1ge. 3-6 11lustrate gections through the eleft, fig. 3 being elose to the apex of the cleft. PIg. 7 shows the tip of the adaxial lip or "cross zone" ("cz") whlch at a lower level is Jolned to the horeeshoe-shaped abaxlal part of the carpel to forn a hollow cyllnder (flgs. 8 and 9, PLATE 53, f1gs. 1-2, PLATE 54). F1gs, 2-5 of PLATE 54 show 
sectlons through the ovular region; in $\mathrm{fig} .4$ procambiun of the ventral trace can be seen within the ovule and in fig. 5 this trace ("tr") 18 within the carpel wall. At this atage the ovule contalns a 1-nucleate embryo-sac.

During maturation of the carpel the cleft becones closed, as the cells lining each half of the cleft become appressed together. This adhesion 1 s weak and with little foree the eleft of aature carpels can be re-opened without much tissue being danaged. Actual closure or the locule occure when the uppermost part of the adaxial lobe bends inwards and a little downarde (compare 11gs. 4, 5 and 7 of PLATE 49) and becones pressed agalngt the upper 1nnemost part of the locule wall. Coupled with this, the edges of the superflelal part of the adaxial lobe are sealed by appression of the lowernost part of the eleft around them. Mature carpels are shown in PLgs, 6 and 7 of PLATE 49, a few days after polilnation which accounts for the withered st1gnat1e region. The external t1p of the cross zone 18 readisy apparent in alde view of the carpel (IIg. 6, "cz") and the ovule is a conelderable distance below this zone. The outalde edge of the cleft is also readily apparent (flg. 7). Development of megarporangis and female sametophytes Hedzearra

Carpels were not sectioned during the process of ovule 1nltiation. The ovile arises as a protuberance on the adaxial wall of the locule alrectly beneath the adaxial 11p, such that 
the vertical plane of blsection of the lip when prolonged downwards, bisects the ovule (PLATE 55, P1 $\mathrm{g}, 1$ ). The carpel in this ilgure 1s $614 \mu \mathrm{high}$ and at this stage the epldernel cells of the stigmatic region have begun their alfferentiation into receptive trichomes and are alightly more elongeted antielinally than epldermal cells eleewhere. The young ovule primordiun contrins falriy discrete layers of cells, but some periclinal aivisions occur within the subprotodermal layer and two cells whlch have been formed by a recent periclinal divigion within this layer can be seen in 118.2.

A hypodernal primaxy parietal cell and subjacent megaspore mother cell are present when carpels are about $1040 \mathrm{~h}$ igh. These cells have arisen from the periclinal alvision of a hypodemal archesporlal cell. The ovule has begun to Invert to an extent such that the young megaspore mother cell and primary parietal cell face the bottom of the locule. The inner Integument has recently been inftiated by anticlinal elongation and pericinal dividion of a ring of protodermal cells, as is usual in anglosperms (Esau, 1953). These inftial divisions are soon followed by other periclinal and anticlinal divisione in the protodermal and subprotodermal cells adjacent to the InIt1al Integument cells. Soon after 1ts formation, the primary parletal cell undergoes a periclinal division and the derivatives divide antielinalig. This 1s later followed by other periclinal and anticlinal divisions of these derivatives to form a numer of layers of cells at the 


\section{3}

micropylar end of the ovule. These layers are also bullt ap by periclinal alvislons within the surface layer of the ovule, as in Laure21s and Peumue (Matritzon, 1935), and a periclinaly dividing surface cell can be seen at "p" in $91 \mathrm{~g} .3$.

A single aberrant ovule was sectioned which contalned two megaspore nother cells (ât the synizesls stage of prophase ro) and is shown in $\mathrm{fig}$. 4. This ovule is sectioned at right angles to the one shown In IIg. 3. At th1s stage the outer 1ntegument has been indtated in a manner sinllar to the inner one although Its growth is asymmetrical and as in Laurelia too, it is not even weakly developed on the slae of the ovule which lles against the funiele (14g. 3). This phenomenon 1s comon in anatropous ovules (Esau, 1953) and appears, from 11.1ustrations, to be the condition in Reurue (Mauritzon, 1935) and In some Lauracese e.g. Litree (Sastr1, 1958) and Dellsohrledis (Roper, pers. coma). The micropyle is formed by the Inner integument alone, as in Laurelia, even in the mature ovules.

By the tine the megaapore muther cell la at prophase I of melosis, the ovule has unaergone a Purther $90^{\circ}$ rotation and is appressed to the adaxial lateral wall of the locule (PLApr 51, 118. 4: PLATE 55, flg. 3). At the end of melosia a 11near, or less commonly $\mathrm{T}$-shaped tetrad of megaspores $1 \mathrm{~s}$ forned, the 1 mnermost of wich 18 functional. In the r-shaped tetrad in PLATE 56, flg. 1, there 18 a diagonal wall separating the upper palr of

- During the preparation of this section the nucleolus of the Innermost : mother cell has been aisplaced into the cytoplasm. 
124

megaspores. The nucleus of one of these 14 es in a different section. According to Maheahward (1950) this type of tetrad in which the well separating the ateropylar megagpores lies at an angle of about $45^{\circ}$ with respect to the chalazal negarpores, Is not infrequent in angiosperas. The ovule is now fully inverted. One fully inverted orule was sectioned with well developed lntegunents but the megaapore mother cell vithin had only reached the prophase I stage (IIg. 2). It Is posalble that auch a megaapore mother celI may not undergo much further development, for a carpel in an open flower was sectioned with a somewhat slinilar ovule in which however the negagpore tather cell had an attenuated nucleus of aistortea ahape at a rtage of prophase I. In other ovules of the sane flover from whloh the ovule ahown In fIg. 2 Was obtalned, the non-funetional megaspores had degenersted and the funotional megepore had undergone cons1derable enlargement (fig. 3). In this section only two of the three degenerated megrgpores can be seen. The carpel 1 a $1880 \mu-2250 \mu$ high at this atage.

Flowere are fuly open with pollen tubes extending through stylar t1ssue when embryo sacs are at she 2-nucleate (PLATE 56, fig. 4) and aubequent stages. As can be seen in the flgure, the micropylar end of the embryo sac is blunter than the chalazal and thls shape is malntalned, at least auming early postfext111zatson atages. Sone withered pollen tubes were observad within mleropyles and between inner and outer Integuments of 
ovules at the 2 and 4 -nucleate stages, including the ovule 11lustrated, although the tubes eannot be clearly seen in the photo. No pollen tubes were observed to have penctrated the micropylar nueellus tissue. Perhaps there 18 some physiological barriex preventing the growth of pollen tubes into this tiseue unt1l the embryo sacs are mature. No ovwes were sectloned which contalned 8-nucleate embryo sacs, desplte the fact that a number of carpels were sectloned from fully opened flowers. It is obvlous that an 8-nucleate embryo sac does form since young seeds contained in adaltion to unl-nucleate zygote and cellular entosperm, the renalne of 2 synergids and 3 antipodal cells. In view of the fact that no ovules were sectloned with embryo sacs older than the uninucleate stage unt11 after pollination, $1 t$ 18 poselble that the pollen tube may act as a stimulus to the further development of the embryo sac. Heslop-Harrison (reported In a dscussion on embryo sac phys1ology in Linffikens, 1964) stated that in some orchids there is no completion of melosis unt1I pollination has taisen place and no formation of an embryo sac and that, "there 1 a certajnly a very close correlation between the advent of the pollen tube and the completion of embryo sec format1on". He adeded that a simllar eraryo sac development can be achieved by replacing the otimulus of pollination by a synthetic auxin like $\alpha$-naphthaleneacetic acld.

Shortly after fert121sation the outer integument consiets of 3-5 layers of cells and the inner comprises 4-6 layers. 


\section{Laure 119a}

In this genus too, carpels were not sectioned during the process of ovule 1nlation. The ovule arlses on the adaxial wall of the locule (PLATE 57, Plg, 1) In a simlar position to the ovule in Hedreargre. The archesporial cell ("a.r.") is present In this young ovule which is within a carpel $650 \mathrm{high}$. The eplarmal cells of the stigmatic region have begun to alfferentiate Into receptive trichomes and are more elongated antlelinaliy than the other epldermals. The archesporial cell alvidea periclinally Into a hypodermal primary parietal cell ("g" in $\mathrm{flg}, 2$ ) and a subJacent prinary sporogenous cell ("s") which as in Hedycarya. enlarges 1nto the megaspore mother cell. The functional atamens of oarpellate flowers with ovules at this atage contalned microspore mother cells whlch were undergoing melosis. As the megaspore mother cell enlarges, the Inner integunent is initiated (PLATE 58, IIg. 1) in a manner almilar to that described for Hedrcame. The carpel is now about $670 \mu$ high. The first dividion of the primary parletal cell is periclinal ( 1 ig. 2) and in the ovule 111ustrated the outer integunent has recently been Inltiated by the periclinal division of protodermal cells, as can be seen at "0.1." which is close to the base of the inner integument. Functional stamens in this flower contained uninueleate mierom spores. When the negaspore mother cell 18 at early prophese I. the outer integunent is more apparent (f1g. 3). The results or a periclinal division within the surface layer of the ovule 
can be seen at "s". Procamblun of the ventral strand has now been differentiated in the base of the ovale. The ovule 111ustrated in 11 g. 4 (contained within a carpel $1860 \mu \mathrm{htgh}$ ) has undergone rotation so that the mleropylar end faces the base of the locule. The megaspore mother cell within is at the diplotene etage of prophase I. In this figure the two derivative of the prinary parletal cell have each undergone an anticlinal division. The ovule does not uniergo further rotation but remins with 1 ts mleropyle alrected downwards. Total rotation has therefore been approximately $90^{\circ}$ in comparison to the ovule in Hedycarys which undergoes a total rotation of approximstely $270^{\circ}$. There is no great unformity in ovule development within a single flower. Thus, one flower contalned ovules in which megaspore mother cells were at prophase I, anaphase I and telophase I atages and other ovules contalned a tetrad of megazpores. At the end of melosis a I-shaped, or less comanly 11near, tetrad of mega spores is formed. In $\mathrm{T}$-ahaped tetrad the wall separating the alcropylar pair of megaspores may be long1tudinal (PLATI 59, NI. 1) or alagonal. In the photo the innemost sunctional megaspore is not in clear focus. On two occasions it was observed that the inegaspore alrectly above the functional one was the flrst to degenerate as ahown in the figure. As the innermost megaspore enlarges into the unl-nucleate embryo sae (flg. 2) pollen gralns become b1-cellular in functional stanens. Fig. 3 lllustretes an ovule in which the embryo sac nucleus is at prophase and the carpel. 
at this atage is $2700 \mu \mathrm{high}$. At the end of this division the two nucle1 move towards opposite ends of the sac (PLATE 60, IIg. 1). As in Hedycarra the chalazal end of the sac is more pointed than the micropylar. Division of these two nuelel is not always synchronous as an embryo aac was sectioned contalning a micropylar nucleus at prophase and two analler chalazal nuclel. A 4-nucleate embryo sac is shown in flg. 2, w1thin a carpel $3500 \mu \mathrm{hlgh}$. Mlg. 3 1llustrates an 8-nucleate embryo sac before there has been wall formation or migration of polar nucle1. Figs. 1-3 are dram to the same scale and it can be seen that there has been a progressive reduction in the sise of nuclet as more are formed. A mature exbryo sac conalsting of three antipodal cells, central fusion nucleus (the polar nuclel fuse before fert1lization) and egg apparatus is shown $\mathrm{in} \mathrm{fg}$. 4. At this stage the outer integument is 2-3 celis thick and the inner integument 18 2-4 cells thick. The cells of the inner integument lining the mieropyle are conslderably enlarged (f1g. 4). The embryo sac is separated by approximately $7-9$ layere of cells from the micropylar surface of the nucelius.

Discusaton

Carpel_ontogeny

In their classic paper on the conduplicate carpel of the Ranales and 1 ts inftial trends of specialization, Balley and swamy (1951) described how they considered the phylogenetic development of a style had occurred in many famlles. They stated that the 
upper sterlie part of the carpel develops a "alender, more or less tapered extension. Durlng earlier phylogenetic stages of the Ceveloptent of this upward projection or style, it is conapleuously conduplicate ...., has two extensive 1ndependent at1gmat1e creats, and compon? is vascularized by both the dorsal and ventrel velno ... Durlng subsequent stages of 1ts phylogenetic epecialization, the "decurrent" etignatio crests become less ond less extensive and are confined to the apex of the ptyle .... The ventral suxfaces of the primitive conduplicate atyle may fuse forning a hollow tube that 1 g Jacketed by glandular cells .... or they my become conorescent forming a solld style with a core of "conductIng" or "transintting" t1 1 aue."

In contrast to the above, in Hedvearsa and Isurelia and in at least flve menbers of the Lauraceae - Umbellularia (Kasap11g11, 1951), Bellschn'edia (Roper, pers. como), Clnnanonun, Lltsea (Sastr1, 1958) and Cassytha (Sastr1, 1962) a "terminal meristem" (Kaangl1g11, 1951) forms a sol1d cylinarleal growth which 1 s covered by the receptive atigmatio trichones. In Belischmledia (Roper, pers. coma.), LLtsea and C1nnamomum (Sastr1, 1958) a small basal gart of the stigmatic-stylar region has a eanal whlch $1 \mathrm{~s}$ derlved from the uppermost portion of the cleft. This type of lauralean st 1 gra 1 s not then analagoue to eertaln other ranalean genera e.8. LLxlodendron (Canright, 1960) whlch has an elongate style and a locallzed terminal stlgma whlch conslsto of two short stigratic oreats between which is the cleft of the carpel. It 
must remain an open question as to whether (a) the stigna in Laure 112. Hedycarya etc., is a new structure, in no way homologous with the type in Liplodendron, and which arose by the evolution of a terminal merlsten above the tip of the carpel cleft or whether (b) the stigna in Laure11a. Hedycarya etc., arose from the type in flrsodendron by the fusion during evolution of the palred at1gmatle ereats and uppermost gart of the carpel eleft Into a solld cylinder without leaving any vestiges of the cleft and creats. Certalnly the former possiblity seets more attract1ve to the writer.

As I have stated, a.l but the top of the locule in Hedrcarre and Laurelis is forred by cylindrieal growth whlch occurs below the cleft. On the other hand Kasapligil stated that in Umbellularia the ovary portion of the carpel was forned by the fusion of the margins of a horseshoe-shaped primordiun (1.e. by closure of the basel part of the cleft) at a very early stage in ontogeny and that "the union is very complete and hence the fust on IIne is not detectable in the mature ovary wall". I do not consider thls $11 \mathrm{kely}$ and Kasapligll does not substantiate hls statement. He may have been 1nfluenced by Balley and Smith's (1943) paper on the carpels of the Winteraceae which he elted elsewhere in which it is clalmed on the basis of the structure of mature carpels alone that there was basal ontogenetse closure of the carpel in auch a way as to leave no external evidence of the closure in this region. Th1s statement has been disproved for two nembers 
of the Hinteraceae by Tucker (1959) and Sampson (1963) who in studying the ontogenetic development of carpels found that the lower part of the locule arose by eylinarleal growth. The carpel of Umbelluiarta bears a conslderable resemblance in external shage and vascularization to those of Hedycarve and Laurel12. It does not seem 11kely that ontogenetic fusion coujd be so conplete as to leave no trace of the line of fusion and it should be borne in mind that the line of fusion would pass through the centre of the ventral (ovular) vascular trace which is present in the form of procamblum at an early stage in the development of the carpels of Hedrcarye and Laure 14. It is of course 11kely, In v1ew of the nature of the apparently primitive conduplleate ranalean caxpels that there has been during evoluti on phylogenetic closure of the lower part of lauraceous carpels. It would seem that Euch closure has occurred when a horseshoe-ahaped prisordium later becones ring-shaped 1.e. an Interealaxy merlstem axises belov the cleft of the carpel. Eames (1961) has emphaslsed that the "carpels of many taxa are closed in part ontogenet1eally and in part congentaluy; in early ontogeny, the primordiun is crescentshaped; later, it becomes ring-shaped".

Kasapl1g11 (1951) stated that "Thus far" he had been unable to observe an adaxial meristem in the earpel of Umbellularle. Such a merlstem is present in Umbelzularga, as in Laure21s and Hedycarsa but Kasaplig11 mistakerily labelled 1t as an ovule (In plate $28 \mathrm{~b}$ of his paper). 
The ontogeny of the earpels of Hedycarye and Laurelita seens basically almilar to that deseribed for some achenes in other farliles e.g. Thalictrun (Ranunculaceae) which is illustrated in 11gure 1184 of Melean and Ivimey-Cook (1956).

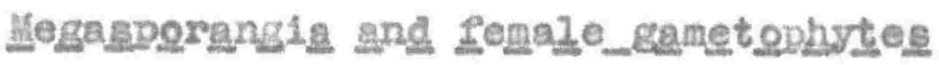

The ovules of liedycarys and Laurelif resemble those of other woody Ranales Ineluding members of the Magnoliaceae, Illiclaceae, Winteraceae, Schisanaraceae (see Hayashi, 1965), Cercidiphyliaceae (Swany and Balley, 1949), Degenerlaceae (Swany, 1949) and Lauraceae (Sastri, 1963) in belng bitegnic, crassinucellate and anatropous with a monosporic B-nucleate embryo sac of the Polygonum tipe. It 1 s not surprising that the Polygonum type of embryo sae is unlversal" within those woody Ranales so far studied in viev of the general opinion among embryologists that there "Is hardiy any doubt that the Polygonum type of the embryo sac is the nost pximitive" (Johri, 1963) from which the other types have been evolved.

Heilborn (1931) atated that Stparuna (subfamily s1parunoldeae) of the Honlmiaceas was unitegmic. The only figure (4a) in his paper in whlch the integument 1: 11lustrated, does not Include cell detall. It $1 \mathrm{~s}$ shown to be conslderably larger on one slde of the ovule and I consider it poselble that the ovule may be bitegmio with the outer (Inconplete) Integument closely appressed

- Mauritzon (1935) suggested that in Peumus (Monimiaceae) enbryo bae deve lopment was probably of the bisporic (A111um) type, but coula not draw a derinite conclusion nox rule out the possib111ty that the embryo aac was monosporic because of the difficulty experienced in aectioning naterial at this stage. 
to the Lnner, as 18 common in Hedycarye and Laurella during later stages of development. Two merbers of the Lauraceae (Laurus noo 121s snd Cassythe flifformis) have been described as unitegmic but 1 has eubsequently been shown that they are in fact bitegric (Sastri, 1963). Maheshwar1 (1950) has noted that the number of integunents is constant in most familles and only in rare cases do unitegnic and bitegmie ovule occur in the cane family. The structure and development of the ovules of peumus (Mauritzon, 1935), Hedyegrya, Laurelfa and nost nembers of the Lauraceae (Sastr1, 1963) are very amliar to one another, except that in Laurelig the micropyle polnts downwaras. An unusual feature in Reums is that the antipodal celle realvide after fertilization to form ap to $20 \mathrm{cells}$ which are thickened to form a weakly developed hyjostase. Such behaviour of antipodal cells was not found within post fertilization stages in the seed of Hedycarve which is classified within the same subramily as Deunus. A hypostase does form in Hedxcarye but from cells outalde the chalazei. part of the eabryo sac. According to Banbacion1Mezzett (1935) the antipodals may redivide in Laumus noblita. Some members of the Lauracese, including Bellochniedis (Roper. pers. comn.), Sassafras (Coy, 1928), Persea (Schroeder, 1952), Cassythe (Sastr. 1962) and a species of Chmpanomus (Sastr1, 1958) have considerably elongated embryo sacs. Other members of this fanlly Inclualng a speeles of Ginnomomum and Itsea (Sactr1, 1958) have an eabryo sac of colaparable shape to the three genera of the 
Monintaceae. Sivaruna eggorst, the other nember of the Monfintaceae whitch has been studied enbryologically, has an aberrant and unique type of eabryo sac development (Helzbom, 1931). It has a rultiple archesporiua in which frequently more than one uninucleate erbryo sac develops but one gains ascendeney and the growth of the othere is suppressed. He1lborn found that the growth of the largest embryo ste was hindered by the early formation of a hypostase beneath the chalazal region of the sac. The eabryo ac becones colled and finally burato. It is not until this stage that the single nucleus divides to form up to 5 nucle1 although no egs apparatus is formed. Helloorn elaimed that sporophytie buds "belng probably the intilal of a nucellax ethoryo" form, but do not wature. He found no traces of enbryo or endospera within well doveloped frutts. It is to be hoged in view of these surpriains reaults that a more ertical study can be made of the development of the ovule in 2. egrerals and in other epecies of the genus. S. Ekgers11 resembles Gassytha in that the latter has a multicellular archesporium. In Cessytha up to six enbryo mace reach maturity but only one 1 s fert 111zed. 


\section{CHOPLER 7}

POLLINATION, ESKTILIZAZTON AND POST BSRTIUIZATION SFAGSS

\section{Hedyearys}

The flowers are greenish and lack nectar. No Insects were observed visiting flowers. It is presumed therefore that the bulk of pollen transference from male to female trees is effected by wind. Hale flowere are formed in abundance each geason at the tips of branches (PLATF 4, IIg. 1) and it was not 1 ced that even slight winde caused a considerable amount of pollen to be shed from the tree. The flowers of female trees within a few hundred yards of male trees were found to have plenty of polien adherent to the atigmas and reed set $1 \mathrm{~s} \mathrm{high.}$

There does not appear to be speclal1zed transmitting tissue within the style. Pollen tubes pass apparently indiscriminately between cells of the style, avolalng the central vasular tissue and on reaching the ovule enter it via the mieropyle. As in Laurelis, in at least some instances, only one synergid 1 s deatroyed by the entry of the pollen tube into the enbryo sac. Antipodal cells persist for some time after fertilization, as in Litseg sebifere. but in contrast to most of the Lauraceae so far stualea, in which they degenerate early (Sastri, 1963).

The endosperw is eellular fron an early stage in which oniy a few endosperm cells were present. Materlal was not sectioned lamedately following fertilization and it is therefore not known 
if the endosperm $1 \mathrm{~s}$ celiular after the flret division of the primary endosperm nucleus. It seems most probable that it is however since in the related genus feumus the endospern is cellular from 1ts inception (lauritzon, 1935). A in Peumas a considerable amount of endosperm le formed before the zygote divides. Soon after fertilization a hypostase of thiok walled cello with tanninlike contents develops in chalazal nucellus tissue (PLATZ 59, Ilg. 4, " $h$ "). In the 11lustration most of the endospera cells have been destroyed during sectioning. By this time, the ep1dermal cells covering the ovule contain heavg deposits of a tannin1ike nature as can be seen in the figure.

Bmbryo development was not stualed in either genus. At maturity the embryo of Hedvearya has two cotyledons whlch possess serrate nargins and the embryo occuples slight Iy less than half of the length of the seed, as 11lustrated in figure 3 H of Perkins and a1lg (1901). Mature seeds of Hedycarya and Laurelia are of the albualnous type, since they contain some endosperm. Immature (green) and mature (orange) arupes of Hedycarva are shown in colour, approximately two-th1xds actual size in plate 267 of Salmon (1963). Fruits are eaten by the nat1ve pigeon Hemiphaga novaeseelandige (Falla et al., 1966). The endocarp of the fruit is hard and stony and it seems likely therefore that the seeds pass Intact through the digestive tract of the pigeon, which therefore acts as a diperval agent, as is the case with the similar fruits of Bellschnledia tawa (Beveridge, 1964). 


\section{Laure 11a}

Pollination has been discussed in chapter 5. In the related genera Doryphore and Atherosperma the 11 owers at anthesis have stlgmas which are splayed out from one another to form a stellate atigmatic eluster in the centre of the flowers (PLATK 13, I1gs. 2 and 3). Thls would provice a large eurface ares for pollen to adhere to. Only one out of hundreds of carpellate flowers of Laurelia examined had a similar atellate "conpound" stigma. In general some of the stigmatic paplliae of adjacent carpels were Interlocked with one another in auch a way that the st1gnas could be separated from one another only with alfficulty. It is posalble that Laurella or 1ts immedlate ancestor once had the type of stellate stigmatic cluster found in Doryhorg. Athorosperme and posibly other members of the Atherospermoldeae, but that this feature has been lost because the stignatic papillae of Laurelia evolved in such a way that they becane eas1ly tangled with those of nelghbouring carpels.

I was unable to trace the couree of pollen tubea through etylar tissue. Fhe pollen tube enters the apex of the locule and passe down the slde of the locule to the base and then entera the micropyle.

Money et al. have noted as a general character for the subfan1ly Atherospermoldeae that the more or lese deeply concave receptacle becomes cupuliform or ureeolate "partleularly subsequent to anthesis". The receptacle of carpellate Laurelia rlovers 
undergoes conbiderable enlargement after anthesis to form a pseudocarp which encloses and concesis the fruts even when the latter are mature (PLATB 6, f1g. 1). The fully enlarged pseudocarp is at flrst green(see plate 181 of Salmon, (1963) in which the pseudocarps are labelled as frults) and of a somewhat rleshy fibrous nature. Within a few months the gseudocarp becomes brownish-grey and woody and splits in half longitudinally (PLATE 61. $19 g .1$ ) to release the planed frutts (PLiT: 26, Plg. 1 and plate 182 of SaImon (1963) in which the frusts are 1ncorrecty descrlbed as seeds). Such plumose achenes would be realizy dispersed by the wind and allbert (1959) has noted that the plumose fruits of Atheroapersa, which from 11lustrations appear very similar to those of Laurelia and other nembers of the subfan1ly, "Ploat 11ke thistle down".

In the mature fruit the embryo occuples approximately the same proportion within the seed as does that of Hedycarye. In contrast to Hedxcarre the cotyledone of Laurella do not have serrate margins. It was frequently found that what appeared to be arture fruita, when dissected contalned unenlarged ovules which had therefore elther not been fert121zed, or, if they had been fert111zed, had undergone little subsequent development. Discusaton

As the foregoing has shown, the plumose, wind diatributed fruite of Laurelis and other members of the Atherospermoldeae,

- he too called them "seeds". 
which are enclosed in pseudocarps, are very different from the drupes of Hedycarya, As far as I can ascertain from the drawlings and deseriptions in Perkine and Gilg (1901) and Perkins (1911) all genera of the Ifonimiaceae have arupaceous fruits except for the subfanily Atherospernoldeas. This is evidence for the view that this Iatter subfamily has long been alstinct from the other neabers of the Monlmiacene. The tauraceae too have drupaceous (and baccate) frults but are without endosperm at maturity (Hutchinson, 1959) in contrast to Hedyearyg and Reumus (Meurltzon, 1935). 
CHAPTER 8

\section{CONCLUSTONS}

Varlous conclusions have been stated throughout this thesis, especially in the aiscussion section at the end of each chapter. These conclusions will not all be repeated in this chapter. In this chapter some of the more important similarities and differences between Hedycarrs and Laurel19 w1II be considered to pernit me to make some conclusions as to their relationship, one to the other. I will then briefly consider the relationships which the Honlmiaceae bears to other fam1lies.

Comparison of Hedvearva and Laure lia

(a) chromosome_numbez

Hedycarra axborea has $n=57$ chromosomea and Laurel1a novegelandise has $n=22$ chromosomes (Ha1r and Beuzenberg, 1959). There is therefore no simple numerical relationshlp between the chronosone numbers of the two genera and this suggests that they are not closely related. I have been unable to $\mathrm{f}$ ind chromosome counts of other members of the family in the 11terature. In the Lauraceae chromosone ounts have been made of 6 genere (18 species). Results were $n=12,18$ or 24 (Darlington and wylle, 1955). One worker obtalned a haplold count of 21 for Leurus nob111s but another worker obtained a count of 24 for this species. Most species had $n=12$ chromosomes and Darlington and Wylle considered that 12 was probably the basie number for the 6 genera. 
There is then no simple numerical relat lonship between chromosome numbers in the Lauraceae and those of Hedvearya and Laurella. Nor does the chromosome number of Laurelia colneide with that of any other member of the woody Ranales 11 ated in Darlington and Hy11e (1955). However a number of species of Maznolia resemble Hedycarya arborea. Hedycarya arborea $1 \mathrm{n}$ having $\mathrm{n}=57$ chromosonea.

\section{(b) Pollen_morghologx}

Hedvearya and other Monimioldeae have acolpate pollen in contrast to the monccolpate pollen of Laurelia and monocolpate or dicolpate pollen of other Atherospermoldeae (Honey et al.). Erdiman (1963) connented that the pollen of the Monlaniaceae is in need of further study but that pollen norphology corroborates the diviaion of the family into the four subfamilies of Money et al. Money et al., considered that monocolpate pollen is the most primitive type in the woody Ranales and that dicolpate and acolpate pollen 18 derived from phylogenetic modiflestion of the former type. If this 1s true, then Laurelia has a more primitive pollen type than Hedvearre.

\section{(c) Nogd_anatogy}

From the deacriptions in Money et al's. paper, Hedvearys and Laurelig have a ainilar type of wood with vessels of a primltive forn in which there are thinwalled angular vessel members with extensively overlapping ends and numerous scalariform perforations. (d) Nodal anatomy and yascungature of _the_leaz Money et al. Found uniformiy unilacunar nodal anatony in the 
fan11. Hedvearya, Laurelia and other nembers of the1r subfamiles have a leaf vasculature which 1 s derived from two systems of vascular strands that are separate and independent at lower levels in the aten (Honey et al.).

(e) Apjogl_rerieterens

No major differenees were found between the apleal merlstems of Hedvagye and Laure 11 a and the merlstens resembled thoee of a number of other woody Fanales (see Chapter 3).

(i) Elowere

Hedvcarye and other Monimioldene have unieexual flowers. Laurelig has unsexual flowers in which the female flower bears staminodes, and transitional bisexual howers with carpels, staminodes and one or a few functional stamens. Other genera in the Atherospermoldere have bisexual, unisexual or transitional 2lowers. It seens clear that the most prinitive type of flower In the fomily 1s bisexual, as in Dorsmora (Atherospermoiteae). Laurelia is moze primitive than Hedreargs in having some transitional biaexual flowers and in having female 1 owers with stam inodee, whereas the male and female llowerg of Hedvearva each lack vestiges of the other sex. However there 1 a a link between the two eubfamilies in that Peumus of the Monimloldeae has female flowere which bear staminodes (Honey et a..).

\section{(8) Staneng}

As stated earlier in this atudy, the stamen of Laurella with 1 ts flament bearing the paired appendages, two pollen sacs 
and valvular dehiscence $1 . a$ a marked contrast to the stamen of Hedrearya which lacke a pronounced fllament and the appendagee and has four pollen sacs whlch dehlsee by longitudinal slits. As stated too, Deumus and Honimis provide a 11 nk between the two subfamilies in having stamen with assoclated appendagea. It does not seem clear which type of stamen has given rise to the other type (see chapters 2, 4 and 5) and I can therefore not reach a conclusion as to whether Hedvearya or Lourella has the more primitive stamen type.

(h) Gaxpe].8

The carpels of Hedycarva and Laurelia are sim1lar to those of the Lauraceae in that the terinina atigmatie part of the carpel has been formed by a terminal solid meristem and this otigmatic region 15 thorefore not homologous to the stigmatio region of many other woody Ronales, Including the Hagnollaceae (see Chepter 6). If we assume that the carpels of the Monlmiaceac have ariaen by phylogenetic modifloation of the conduplicate type (see Belley and Swamy, 1951), then the carpel of Laurelia 1 a more priative than that of Hedrearre in posesaing a longer eleft (see Chapter 6). On the other hand Ledycaxva may have a more primitive carpel vascuzarization because it has supraovular traces whlch may represent vestiglal traces to fomerly existent ovules in ancestors of the group (see chapter 2). As I have noted, Atherosperves of the Atheroapermoldeae provides a link between the two subramilles In that it has some carpels with the supraovular traces. An 
aditional difference between the carpels of Hedycarye and Laurelia is that the former has the upper part of the carpel, which 1s covered by the stlgratic surface, vascularized. I can reach no conclusion as to which carpel is the more primitive in this respect. The knobbly stigmatic region of the carpel of Hedycarva contrasts with the elender cylindrical stigmatie region in Laurelia (see Chapters 2 and 6 ). In this case it would appear that the stignas of the two genera have evolved in different directions and that one type is therefore not necessari2y more primitive than the other. The carpels of liedycama resemble those of the Lauracese In that the micropyle of the ovale points upwarde whereas in Laure 21a it points downwardi. It does not seem possible to determine which of the se two types of micropyle orientation is the nore prinitive.

To sum up, It would appear that the carpels of Hedveary and Laurelia are basically sinilar but that during the course of evolution each has retalned some primltive features not found in the other and each has developed independent reatures.

\section{(1) Druits}

The drupes of Hedyceryg and other members of the Monimioldene are: a considerable contrast to the pseudocarps whlch enclose plumose achenes in Laurelis and other Atheroepemoldeae. Here too It may not be a case of one type of frult giving $x$ se to the other but rather a case of evolution taking place in two alfferent directions from a basic type. Thus, the receptacles of fenale 
145

flowers are cupuliform or urceolate in both the flonimioldeae and Atherospermoldeae, but in the latter subfanily this feature has become exaggerated, especlally after anthesis, to form the pseudocarp.

\section{(j) Embryology}

There are no basic differences in the developient of the megasporangia and female gametophytes of Laurelis and Hedrearre and the development of these stages resembles that found in most other woody Ranales (see Chapter 6).

The development of alcrosporangia is basically elmilar in the two genera. However haure 1 a difers from Hedycarva and nembers of the Lauraceae so far studied in not having the successive type of cytokinesis in the melotic divialon of the pollen mother cells. This alfference is not however a dagnostic feature of the Atherospermoldeae as Atherosperma has cytokineals of the successive type (see Chapter 4).

overald conclugions

I would conelude that Hedvearya and Laurelia and other members of the two subfan1l1es, Insofar as they have been investIgated, share a core of basic features whlch warrant o the retention of the subfaillies within a single fam1ly. However there are a number of quite basic differences in the two subfamilies which suggeats that they have been eeparated from each other for a long time and have undergone considerable evolution in different directions. 
Relationshlos of the Monimiaceas

As I have Indicated throughout thla work, Hedrearys and Iaurelis and other generg of the Honfiniaceae which have been stuased, seen most closely related to the Lauraceae. The two famliles can be conventently separated in that all member of the Lauraceae have a single carpel per flower whereas the Monimiacere have more than one carpel per flower with the exception of Xymalos of the Monlaioidene which has a unicarpellate fenale flower (Honey et a.). According to Balley and swany (1948) large mue1lage celle earve also as a criterion for differentlating the Mondmiaceae (In which they are abeent) from the lauracese (In which they are present). The Lauracese show far less variation $2 \mathrm{n}$ most of their features than do menbers of the Mondalaceae. That is to say, the Lauraceae 1 a comparatively tightly knit fanily in which the nembers show little variation in, for example, elower, frult and wood structure (see Hutchinson, 1964) in comparison to the Monlmiaceae in whlch it could be argued with some justirleation that the four subfamiles should be ralsed to the status of separate, but closely related fan1l1es. The Monimiaceae also seem to retain some prindtive reatures not found in the Laureceae, eapecially in their perianth parts. There is therefore merit in Fenes (1961) auggestion that the "Monlmiacese perhaps form a Iink between the Ranales and Laurales". W1th the exception of the Moninlacere and Lauraceae, the other families in the Laurales (sensu Hutchinson, 1964) have not been studied in sufflelent deta12. 


\section{7}

to enable detalled comparisons to be made with them. The Monlatacese and Lauracea and other Laurales, as well as bome other famllies which I. w1II not dlscuss, seen clearly to occupy a place within the fringes or the woody Ranales (sensu lato). Conpared to many familles in the woody Ranales they are considerably advanced in a number of features. For example the Lauraceae and Monimiaceae possess vessels in comparison to the pritritively vesselless members of the order e.g. Winteracea. However the former samilies have a comparatively primltive type of vessel and one vesselless genus, Amborella, 1s consldered by Money et al., to be closely related to the Monimlacese and Hutchinoon (1964) even includes it within this fanily. The stanens and carpels of the two fam1lies aeen considerably advanced in their structure from the apparentiy primitive stamens and carpela in the Degenerlaceae, Finteraceae, Magnollaceae and HImantandracere for example, but they do appesx to have been derived by phylogenetie modification of these nore pringtive types.

It seems beyond the scope of this work for me to discuss each woody ranalean family in turn and compare it with the Moniniacese. Sufrice to say that my results relnforce the conolusions of Balley, Swany and coworkers. They constdered thet the ranaloan fandiles posessing monocolpate pollen and phylogenetieally derived alcolpate, polyporate and acolpate pollen and having "ethereal oll cell" fall Into two groups whlch are not closely related to each other. Thelr groups were:- 
Aroup A: nodes unllacunar

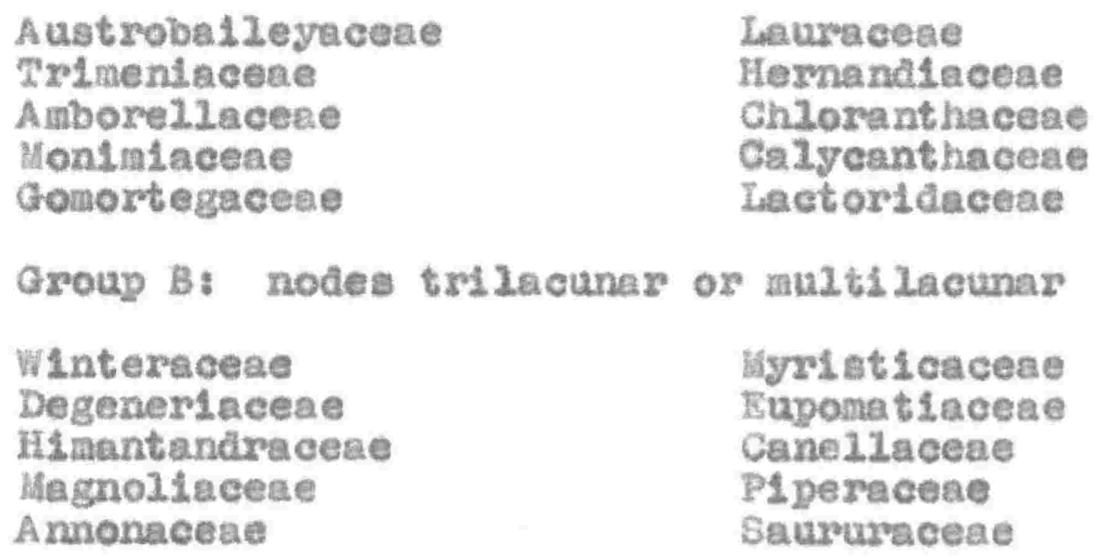

Honey et al.. concluded that seven famllies of groug $A$ "are more or loss elovely related, and therefore form a naturel group1ngt". These seven Pas11es are the Austroballeyaceae, Trimenlaceae, Amborellaceae, Monlaiaceae, Gonortegaceae, Lauraceae and Hernandiacese. What new results I have obtained. In this stuay, especially those relating to embryology, support these conclusions and Indicate that the Ifonimiaceae is not closely related to the Winteraceae, Magnolisecae, Degenerdaceae and other nembers of Group B, Insolar as they have been studied, but that the fanily is closely relsted to the Lauraceae although less closely related to the meabers of other fanilies in Group A which have so far been studied in detall e.g. Aftroballew (Ba12ey and Swany, 1949) and tactorts (Carlquist, 1964). 


\section{APPERDIX}

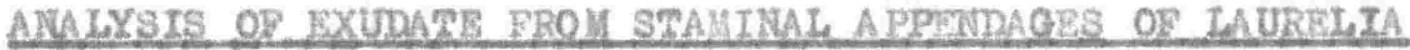

Howers were collected from acveral trees on the west slde of Lake Ponul in late October and early Novenber 1966. They were viewed under the binocular mlcroscope and exudate was removed from the surface of the appendages by meano of a sterilized platinum 10op. Care was taken to ensure that the exudate collected was not contaninated with polien grains.

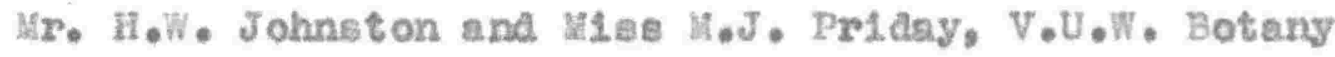
Department then tested the exudate which had been spotted on thin layer plates conted with a cellulose-ellica gel adeorbent, prepared by the method of Turner ane Redgwej1 (1966). Platee were run in a n-butanol - acet1e sela - water solvent (12:3:5 being the respective proportions by volune) and sprayed with an1IIne hydrogen phthalate, then heated in sn oven. Comparison w1th runs of etandard eugars revealed that the nectar contained large amounts of sucrose. Mr. Johnston considered that there may have been a trace of another agar, postibly raffinoe, present too, but results were inconclualve. 


\section{BIBLIOARABHY}

Abbreviations for perlodlcals have been taken, where possible, from the "World List of Scient1fic Perlodleals", Lth Fd1tion, publiahed by Butterworths, London, 1964.

An asterisk beslde a paper indicates that it was not seen In the original.

BAILEY, I.W.

1956. Nodal anatomy in retrogpect. J. Arnold Arbor. 37: 269-287. BAILI, I. H. A NAST, C.G.

1943a. The comparative morphology of the WInteraceae. I. Pollen and stamens. J. Amold Arbor. 24: 340-346.

$1943 \mathrm{~b}$. II. Caxpels.

J. Arnold Axbor. 24: $472-481$.

1945. VII. Summaxy

and conclusions. J. Axnold Arbor. 26: 37-47.

BAILIY, I.W. B BMIH, A.C.

1942. Degenerlaceae, a new fam11y of Ilowering plants fros F1j1. J. Arnold Arbor. 23: 356-365.

BAILEX, I.W. \& SWAIX, B.H.L.

1948. Ambore12g trlchonoda Ba112. a new morphologloal type of vesselless alcotyledon. J. Arnold Arbor. 29: 245-254. 1949. The morphology and relat Lonshipe of Austrobs 1eza. J. Arnold Arbor. 30: 211-226.

1951. The conduplicate carpel of alcotyledons and 1 ts inttal trenda of speclalization. Am.J.Bot. 32: 373-379. 
BA MBACIONI-KEZZETYI, V.

91935. Rlcerche morfologlche sulle Lauracea. to aviluppo dell" ovalo e del sechi pollinicl nel taurus nob12ts L. Ann.Bot." Roma, 21: 1-17.

BRRRY, B.W.

1935. The Mondalaceae and a new Laure119. Bot. Gaz. 96: 751-754. BEVERIDOE, A.E.

1964. Dispersal and destruction of seed in central North I land podocarp forest: Proc. N.Z.ecol. Soc. 11: 48-55. CANRIOHT, J.E.

1952a. The comparasive morphology and relationahips of the Magnollaceae. I. Trends of gpecialiation in the etamens. Aa.J.Bot. 39: $484-497$.

19520.

II. SIgnifieance of the polien. Phytomorphology 3: 355-365.

1960.

III. Garpels, Am.J.Bot, 47: 145-155.

1963. Contributions of pelien morphology to the phylogeny of some ranalean families. Grana palyno2. 4! 64-72. CARLQUTaT, 8 .

1961. Comparat1ve plant anatoay. Holt, RAnehart and Winston Ine., New York.

1964. Morphology and relationghtps of Lactordaceae. A11so 5: $421-435$.

CHRESIBHAN, T.S.

1925. Manual of the New Zealand Iora. 2nd Bditlon. N.Z. Govt. Printer, Wel11ngton. 
COUPER, R.A.

1960. New Zealand Mesozolc and Calnozolc plant microfossils. N.Z. geol. Surv, paleont. Bull. 32.

coY, G.V.

1928. Morphology of Bessafras in relation to phylogeny or anglosperms. Bot. Gaz. 86: 148-171.

CURTIS, W.:

1967. The student's Plore of Tamania. III.Govt. Printer, Tasmania. DARLINATON, C.D. A WYLE, A.P.

1955. Chromosome atlas of flowering plants. 2nd Edition. George Alien and Unwin Lta., London.

DARLIHOMON, C.D. \& LA COUR, L.F.

1960. The handing of chronosones. 3ra Edition. George Allen and Unwin Ltd., London.

DAWSOK, J.W.

1963. Origins of the New Zealand alpine flora. Proc. N.Z. ecol. Boc. 10: 12-15.

DAUMANN, R.

*1931. Zur morphologizehen Wert1gke1t des B2ütennektarien von Laurus. Beih. Bot. Centribl. Erste Abt. 48: 209-213. EAALS:S, A.J.

-1931 The vascular anatony of the flower with refutation of the theory of carpel polgnorphism. Am. J. Bot. 18: 147-188. 1961. Morphology of the ang1osperme. HeGraw-H111 Book Coy, Hev York. BICHLR, A,

+1878. Bluthendigramme. Bd. 2 : 131-134, Le1pg1g. 
BWGL R, A.

*1926. Kurze Erläuterung der Blütenund Fortplanzungverhältrisse. Die naturlichen Prlanzenfinilien. 2nd Edition, Lelpzig.

BRDTMAN, G.

1963. Prignology. Advances in Botanteal Research it 149-208, A caden1e Press, London.

BSAU, K.

1953. Plant anatony. W1ley and Sons, New Yoxk.

FALIA, R.A., GIBSON, R.B. \& TURBOT\%, B.a.

1966. A field gulde to the birds of New Zealand anch outlylug 18Iande. Colitins, London.

FLEMING, C.A.

1963. Age of the alpine biota. Proc. K.2. ecol. Soc. 10: 15-18. GIFFORD, E. J. Jr.

1950. The structure and developnent of the shoot apex in certain woočy Ranales. Am. J. Bot. 37: 595-611.

1951a. Early ontogeny of the foliage leaf in Dplmya winteri vax. chllensts. Am. J. Bot. 38: 93-105.

1951b. Ontogeny of the vegetative axillary bud in Drinve winters var. chilensie. Am. J. Bot. 38: $234-243$.

1954. The shoot apex In anglosperme. Bot. Rev. 20: 477-529. GILBERT, J.H.

1959. Porest succession in the Florentine Valley, Tasmania. Pap. Proc. R. Soc. Tam. 93: 129-151.

GLïCK, H.

*1919. Blatt-und blutennorpholog1sche studien. Jena. 
GREGOERE, V.

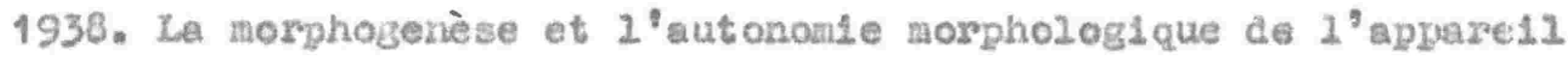
flore.. I. La caryelic. Ceilule 47: 287-452.

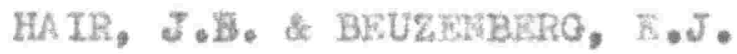

1959. Contrtbutiono to a chronosone atlas of the Nev Zealand flora. 2. Micellaneous families. N.2. J1 Scl. 2: 148-156. HAYASHI, $Y$.

1960. On the microsporogenesic and pollen morphology in the fan1ly Magnoliacese. Sel. Rep. TChoiku Univ. Sex. IV (B101.) 26: $45-52$.

1965. The comparstive embryology of the ragnoliaceae $(8.1$.$) in$ relation to the systematic consideration of the family. Se1. Rog. Tôholku Unstv, Ser. IV (Biol.) 31: 29-4i4.

* HESLOP-HARRISOF, J.

1957. The expertimental modifleation of sex expression in flowering plants. B101. Rev. 32: 38-90.

1959. Growth subetances and Plower morphogenesls. J. Linn. 3oc. (Bot.) 56: 269-281.

1963. Ultrastruetural aspects of afferentiation in sporogenous t1.sue. Symp. Soc. exp. B101. 17: 315-340.

1964. Cell walls, cell gembranes and protoplasmic connect1ons during malosia and pollen development. In "Pollex physlology and fert111zat1 on" pp. 39-47. Eaited H.F. Linsicens, North-Yolland Publishing Co.., Ansterdan.

1966. Cytoplasmic continuities auring spore formtion in flowering plants. Endeavour 25: 65-72.

* heilloorn, o.

1931. Studies on the taxonomy, geographical distribution and embryology of the genus Siparuna Aubl. Suensk. bot. Tidskr. 25:202-228. 
HUTCHINS ON, J.

1959. The fam1lies of flowering plants. Vol. I, Dicotyledons. 2nd Edition. Oxford Univerelty Press, London.

196. The genera of rlowering plants. Vol. 1. Oxford Univerelty Prese, London.

HIEPKO, P.

1965a. Vergleichend-morpholog1sche und entw1cklungsgeschichtliche Untereuchungen uber das Perianth bel den Polycarplcae I. Bot. J6. 84: 359-426.

19650.

II.

Bot. Jb. 84: 427-508.

IIJIMA, M.

1962. A comparative study on tapetum. Cytologla 27: 375-385. JOHANSTEN, D.A.

1940. Plant microtechnique. Mecraw-H111 Book Coy, New York. JOHRI. B.M.

1963. Female gametophyte. In "Recent advances in the embryology of anglosperns" pp.69-103. Bdited P. Waheshwari, Inter-

* national Society of Plant Morphologists, Univeralty of Delhi.

LA COUR, L.

1949. Nuclear differentiation in the polien grain. Feredity, Lond. 3: $319-337$.

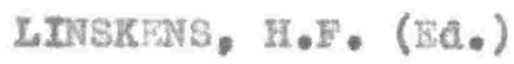

1964. Pollen physiology and fert11ization. North-Holland Publishing Co., Amsterdam.

* KASAPLIGIL B.

1951. Morphological and ontogenetic studies of Umbellularia salifornica Nutt. and Laurus nobilis L. Univ. Calif. Publs Bot. 25: 115-240. 
LLOYD, B.

1950. A dictionary of botanieal teras. University of London Press, London.

MeLEAN, R.C. \& IVINEY-COOK, W.R.

1956. Textbook of theoreticel botany. Vol. II. Longmans, oreen and Co., London.

MAHESHWARI, P.

1950. An introduction to the embryology of angiosperms.

HeQrew-IH111 Book Co., New York.

MARSDEN, I: P.F. A RAILEY, I.W.

1955. A fourth type of nodal anatony in dicotyledons, 11luatrated

by clerodendron trichotomum Thunb. J. Amold Arbor. 36: 1-51. MA URITZON, J.

1935. Zur Rmbryologie von Peumus boldus. Arehivio Botanico 11: 317-327 (Nuova Ser1e: 1).

MELVILLT, R.

1963. A new theory of the anglosperm flower: II. Kew Bull. 17: $1-63$.

MEZ, C.

1889. Morphologische Stualen über ale Lauraceen. D1ss. Berlin 1888. Verh. Bot. Ver. Brandenburg 30: 1-31.

MOSRLEY, U⿺辶.

1958. Morphologieal studiea of the Nymphaeacea I. The nature of the stamens, Phytomorphology 8: 1-29.

1961. II. The Plower

of Nymphere. Bot, Gaz, 122: 233-259.

MONEY L.Wh, BAILEY, I.W. \& SWAMY, B.6.L.

1950. The morphology and relationships of the Monimiaceae. J. Arnold Arbor. 31: 372-404. 
MOSELEY, M०F・ Jr. (cont1 nued)

1965. Morphological studies of the Nymphaeaceas III. The Ploral. anatomy of Nuphar. Phytomorphology 15: 54-84.

NEWHAN, I.V.

1965. Pattem in the areristems of vascular plants III. Pursuing the patterns in the apleal meristem where no cell 1 a permanent eel1. J. Linn. Soc..(Bot.) 59: 185-214. OKSALA, T. O THERMAN, E. 1958. The polarized atages in the me1osis of 1111aceous plants. Chromosoma 9: 503-513.

PERKTIS, J.

1911. Monimlaceae. Das Prlanzenreich 49 (rV: 101 Nachträge): 1-67. PERKINS, J. \& GILA, E.

1901. Monimiaceae. Das Pflanzenreich 4 (IV: 101 Nachträge): 1-122. PERCIVAL, M.S.

1961. Types of nectar in ang1osperms. New Phytol. 60: 235-281. PERIASAMY, K. \& SWAIY, B.O.L.

1959. Studles in the Annonacea I. Microsporogenesis in Cananga odorata and M172usa wightLana. Phytomorohology 9: 251-263. PHILIPSON, W.R.

1949. The ontogeny of the shoot apex in alcotyledons. Biol. Rev. $24: 21-50$.

RHNDLE, A.B.

1930. The classifleation of flowering plants. Vol. I. 2nd Edition. Cambridge University Press, Cambriage. 
RHOADIS, M.M.

1961, Melosis, In "The Cell" Vol. 3. Baited J. Brachet and E.A.

* Mirelky, Academ1c Press, New York.

RODAAY, L.

1903. The Tasmanlan flora, John Vail, Govt. Printer, Hobart.

SALIM N, J.T.

1963. New Zealand flowers and plants in colour. A.H. and A.W. Reed, Wellington.

SAMPSON, $B \cdot B$.

1961. Studies on the genus Pseudowinterg (Winteraceae), with emphasis

on the floral morphology of Preudowintera axillaris (J.R. and

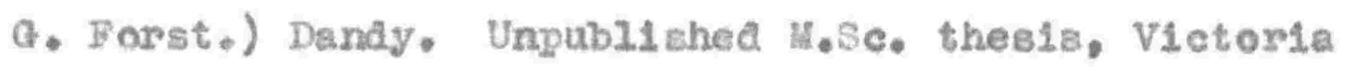

University of Wellington.

1963. The floral morphology of Preunowinterg, the New Zealand nember of the vesselless Winteraceae. Phytomorphology 13: $403-423$. MASTRI, R.L・N•

1958. Studies in the Laurecese II. Bmbryology of Clmnamomum and Litsea. J. Indian bot. Soe. 37 : 266-278.

1962. III. Embryology of Cassutha. Bot.

Gaz. 123: 197-206.

1963. IV. Comparative embryology and phylogeng. Ann. Bot. (n.s.) 27: $425-437$. SCFMTIDT, A. -1924. Histologische 3tudien an phanerogamen Vegatationspunikten. Bot. Arch. 8: 34,5-404. * RICKETT, H.W.

1955. Materials for a dictionary of botanical terms III. Inflorescences. Bull. Torrey Bot. Club. 82:419-445. 
SCHROEDFR, C.A.

1952. Floral development, syorogenesis and enbryolosy in the Avocads, Pesiea aneriana. Bot. Gaz. 113: 270-278. SWITH, A.C.

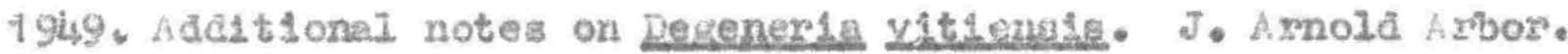
$30: 1-9$.

BTEEFEN, K.

1963. Hale ganetophyte. In "Recent advances in the embryology of angiosperas" gI. 15-40. Ed1ted P. Maheshwar1, International Soelety of Plent Morphologistg, Unlveraity of Delhs. STOUDF, H. H.

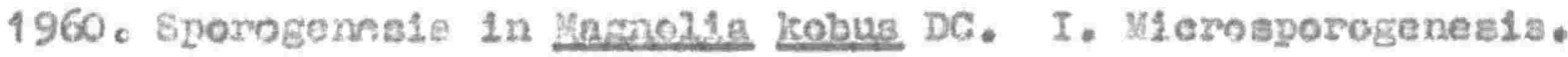
Proc. Pa Acad. Sci. 34: 29-38.

WUALIV, B.O.J.

1949. Further sontribut1ons to the morphology of the Degenerlaceae. 3. Ammola Axpor. 30: 10-38.

1952. Some agpecta in the exbryology of Zygograum ba1.11ond v. Tlegh. Proc, natn. Inst. Sc1. Ind1a 18: 399-1406.

1964. Observatione on the 12ored norghologt and ombryology of Sirmong tubarosa Lour. Phytomorghology 14: 458-468. SWALY, B.QT, L, \& BAILEY, I.W.

1949. The momhology and zelationohlpa of Coresdiphyllum. 7. Arnold Arbor. 30: 187-210.

1950, Bareandra, a resselless genus of the Chinrenthacea. J. Arnold Arbor. 31: 117-129. 
TUCKGR, S.C.

1959. Ontogeny of the inflorescence and the Hower in Dximys winteri var. chtlensis. Univ. Cal11. Publs Bot. 30: 257-336.

1960. Ontogeny of the 11oral apex of Mehal La fuscata. Am.J. Bot. 47: 266-277.

1961. Phyllotaxis and vascular organlation of the earpele in Mehe11a euscata. An. J. Bot. 48: 60-71.

1962. Ontogeny and phyllotaxis of the terminal vegetative shoots of Hehe118 fuscatg. Am. J. Bot. 49: 722-737.

1963. Development and phyllotaxls of the vegetative ax11lary bud of Hchella fuecata. Am. J. Bot. $50: 661-668$.

TUCKER, S.C. \& GIMFOPD, F.H. Jr.

1964. Carpel vascularization of Drings lanceolata. Phytomorphology 14: 197-203.

1966a. Organogenesis in the carpellate flover of Drimys lanceolata. Am. J. Bot. 53: 433-442.

1966b.Carpel development in Driars lanceolatg. Am. J. Bot. 53: $671-678$.

TURWER, N.A. \& RTDQWELL, R.J.

1966. A mixed leyer for separation of anino acias by thin-layer chromatography. J. Chroat. 21: 129-132. THORNE, R.F.

1963. Some problems and guiding principles of angloeperm phylogeny. Am. Nat. 97: 287-305. 
Trothi, W.

-1933. Be1tragé züx morphologies des gynaeceums. Planta 17: 1-18. 41939. Die morphologieche Natur der Karpelle. Chronlea bot. 5: 38-41. WARDLS, P.

1963. Growth habits of New Zealand subalpine ahrubs and trees. N.2. J1 Bot. 1: 18-47. WATERKEYN, L.

1962. Les parois microsporocytalres de nature eallosique chez Helleborus et Iradescant1a. Cellule 62 : 225-255. WEST, G.

1930. Cleistogamy in V10Ia plyinlana with especial reference to 1ts eytological aspects. Ann. Bot. $44: 88-109$. WIGGLESWORTH, $V_{\bullet} B$.

1964. The 11fe of insects. Weldenfeld and Nicolson, London. WILLIS, J.C.

1955. A dictionaxy of the flowerling plants and ferns. 6th Edition. Cambridge University Press, Cambridge.

1966. 7th Ealtion.

Revised by H.X. Alry Shaw, Cambridge University Press, Cambriage. 
STUDIES ON THE MORPHOLOGY, ONTOGENY AND EMBRYOLOGY OF THE FLOWERS OF HEDYCARYA ARBOREA J.R. et G.Forst. (SUBFANILY MONINIOIDEAE) AND LAURELIA NOVAF-ZELANDIAE A.Cunn. (SUBFAIILY ATHEROSPERMOIDEAE) OF THE FAMILY MONIMIACEAE.

$$
\text { Volume } 2 \text { - PLATES }
$$

Thesis submitted in partial satisfaction of the requirements for the degree of Doctor of Philosophy in Botany, at Victoria University of Wellington, 


\section{PLATT 1}

Figure 1 Foliage of Laurelia novae-zelandiae with male inflorescences a short time before flowering. In the axil of the large leaf at upper left, is a bud which is either a dormant vegetative one or an inflorescence bud which will not develop into a mature inflorescence until the following year. Photo taken at Lake Ponui on 30-10-66. Approximately natural size.

Figure 2 Mixed inflorescence of Laurelia novae-zelandiae approaching anthesis. All but the lowermost (sterile) bract pairs have abscissed. Note the vegetative bud in the leaf axil at right. Further details in text. Linear magnification $\mathrm{X} 3.5^{\prime}$ 


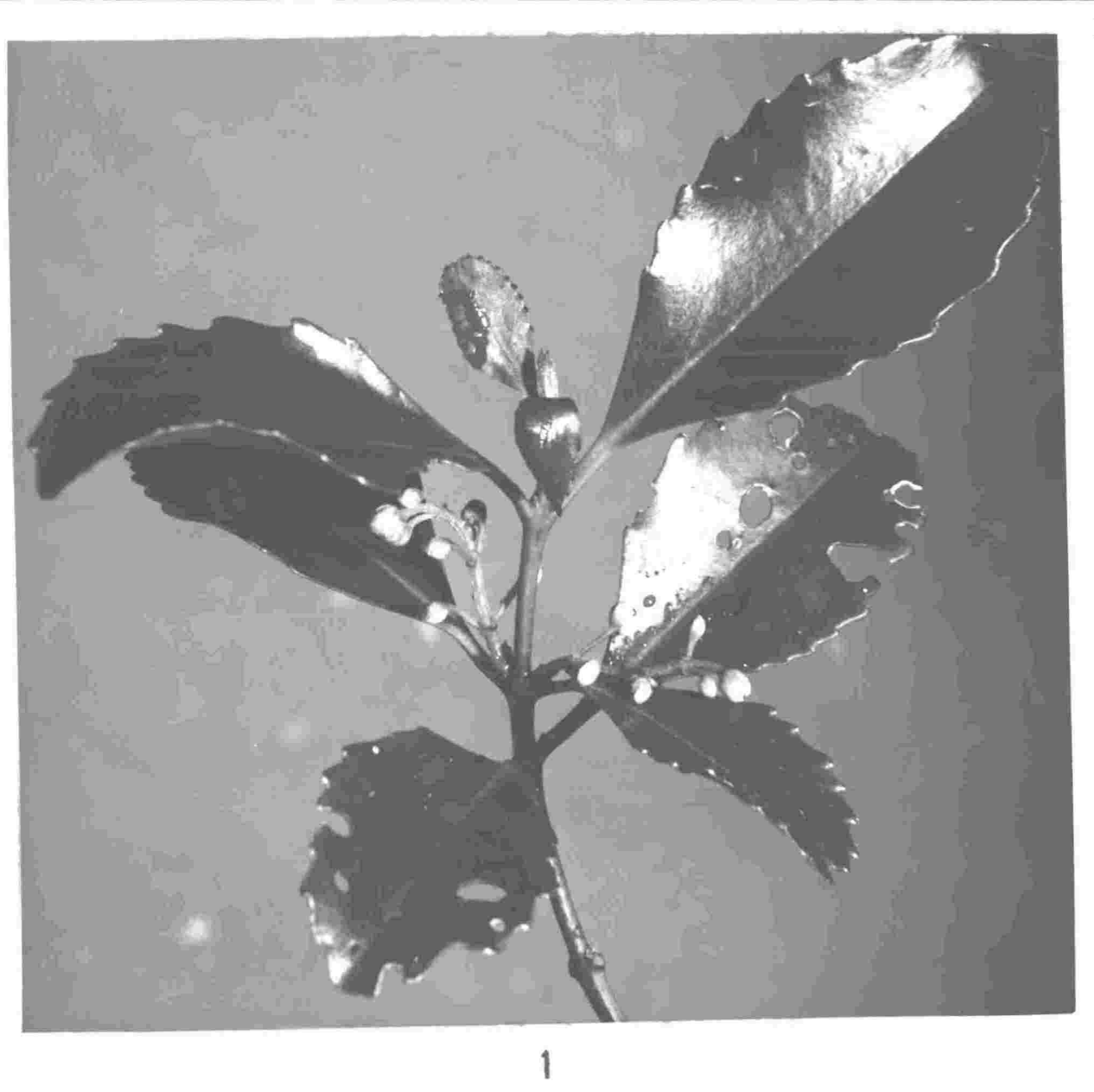

PLATI 1 


\section{PLATE 2}

Figure 1 Compound mixed inflorescence of Laurelia $\underline{n} \cdot \underline{z}$. near anthesis. There are three pairs of female flower buds, situated below the terminal male flower bud. Photo M.D.King. X 3

Figure 2 Compound male inflorescence of Hedycarya arborea near anthesis. The lowermost flower bud and its pedicel ( facing camera) have been excised. Photo M.D.King. X 2.5

Figure 3 Foliage and inflorescences of Laurelia $\underline{n} \cdot \underline{z}$. Approximately natural size. 

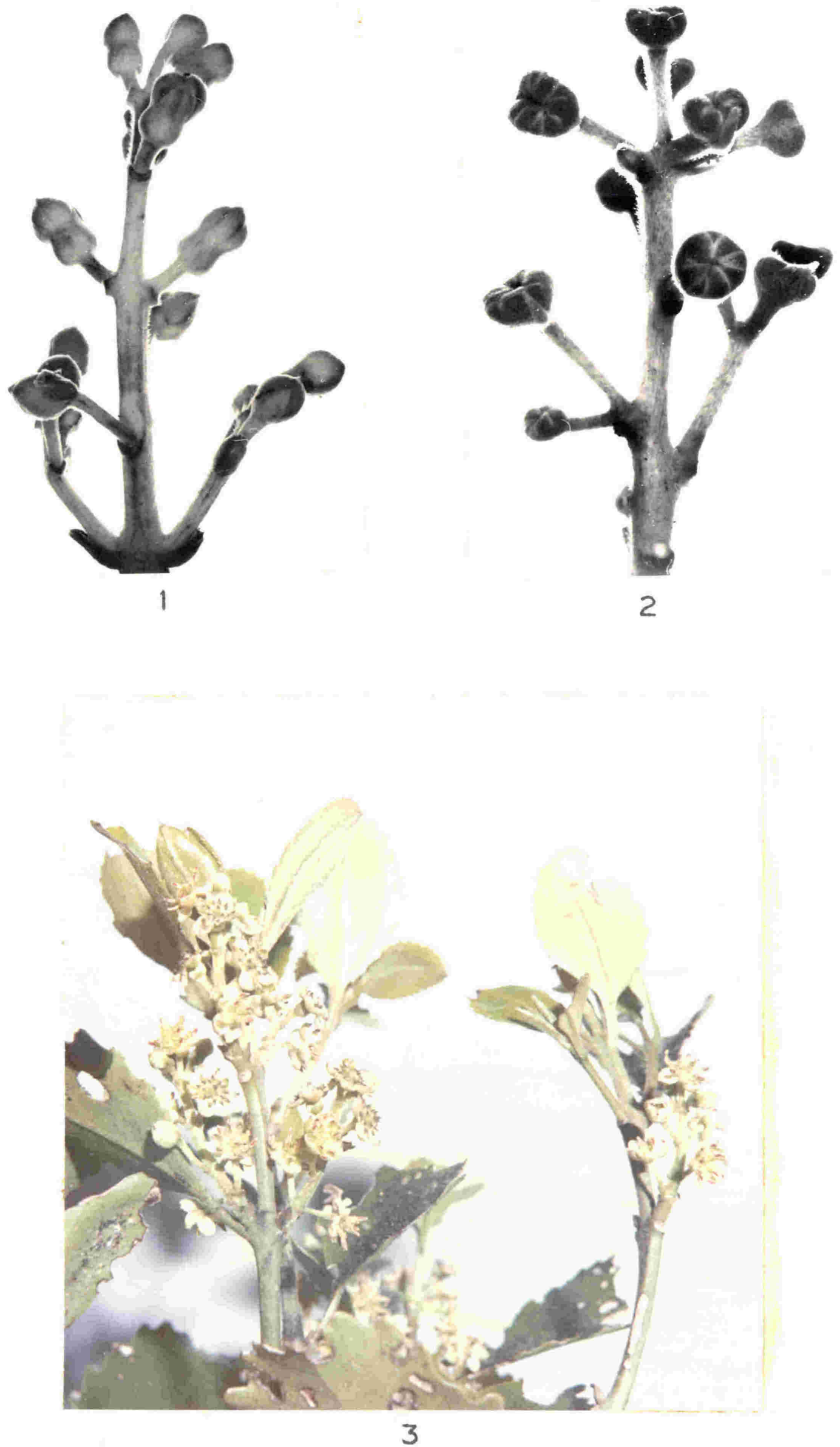


\section{PLATE 3}

Diagrans of inflorescences of Laurelia n. ‥ For simplicity the flowers are depicted as being in one plane whereas they are actually decussately arranged. Not drawn to any scale.

$$
\begin{aligned}
\text { m or } M & =\text { male flower } \\
c \text { or } C & =\text { carpellate flower } \\
\text { br }= & \text { the position of a sterile } \\
& \text { bract in figure } 4
\end{aligned}
$$


PLATE 3

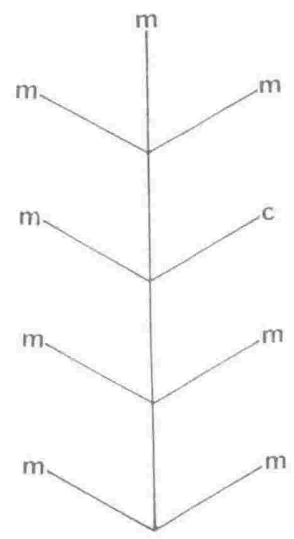

Fig. 1

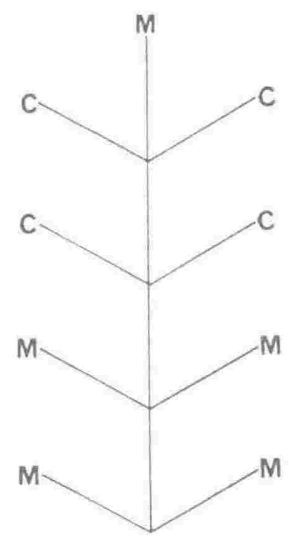

Fig. 2

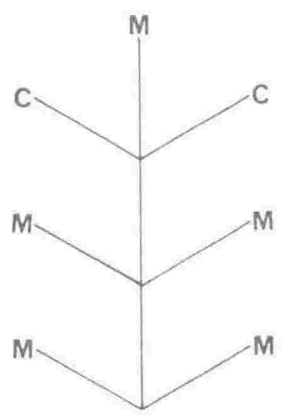

Fig. 3

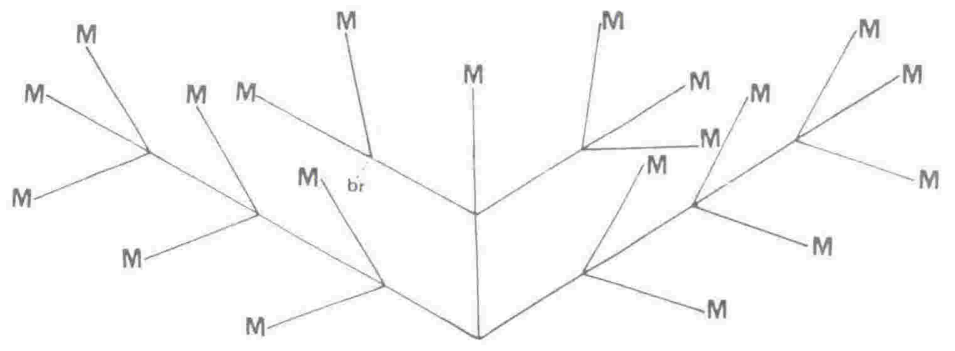

Fig. 4

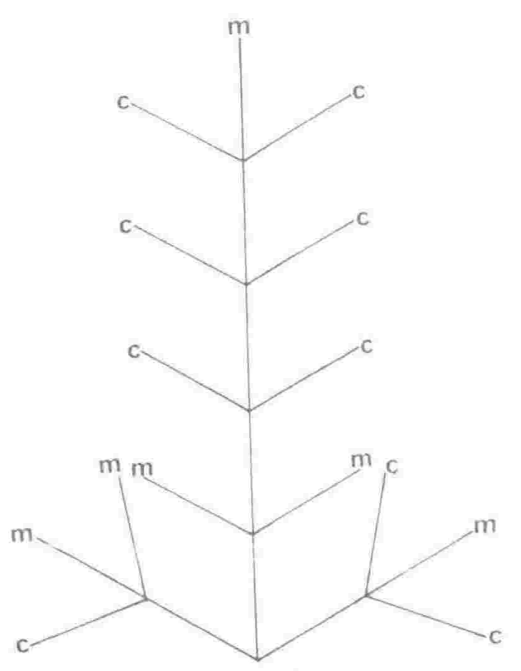

Fig. 5

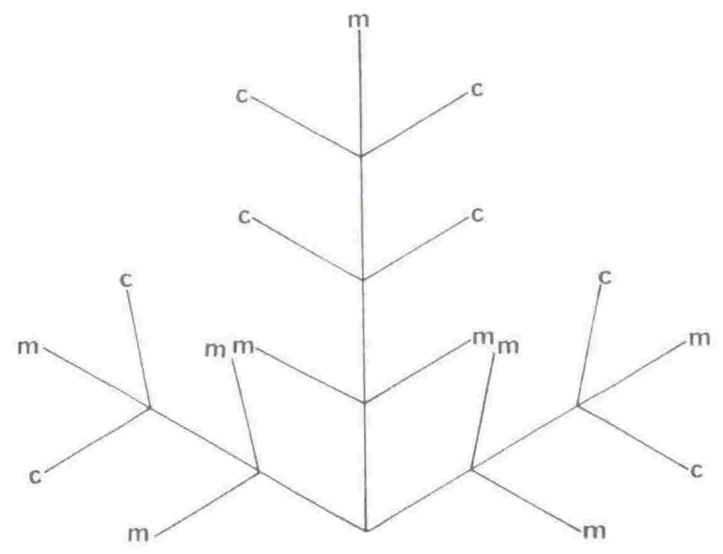

Fig. 6

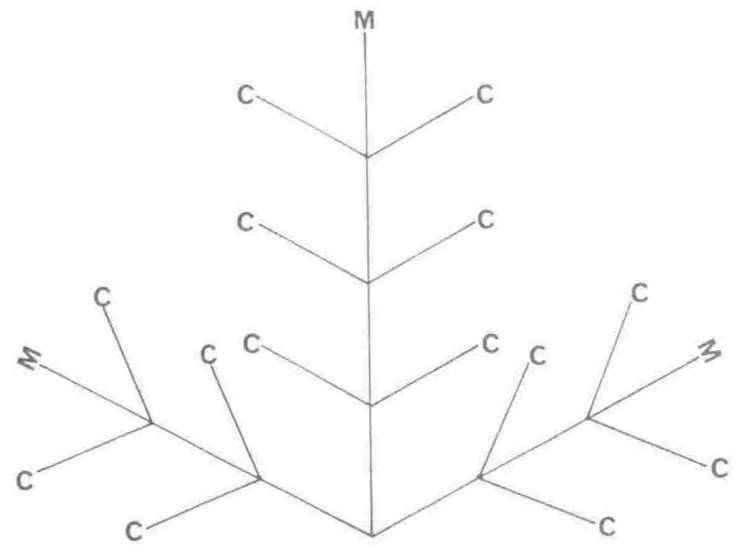

Fig. 7

Laurelia inflorescence 
PLATE 4

Fisure 1 Nale flowers of Hedycarya arborea. Approximately natural size.

Figure 2 Female inflorescence of Hedycarya arborea. $x 3$ 

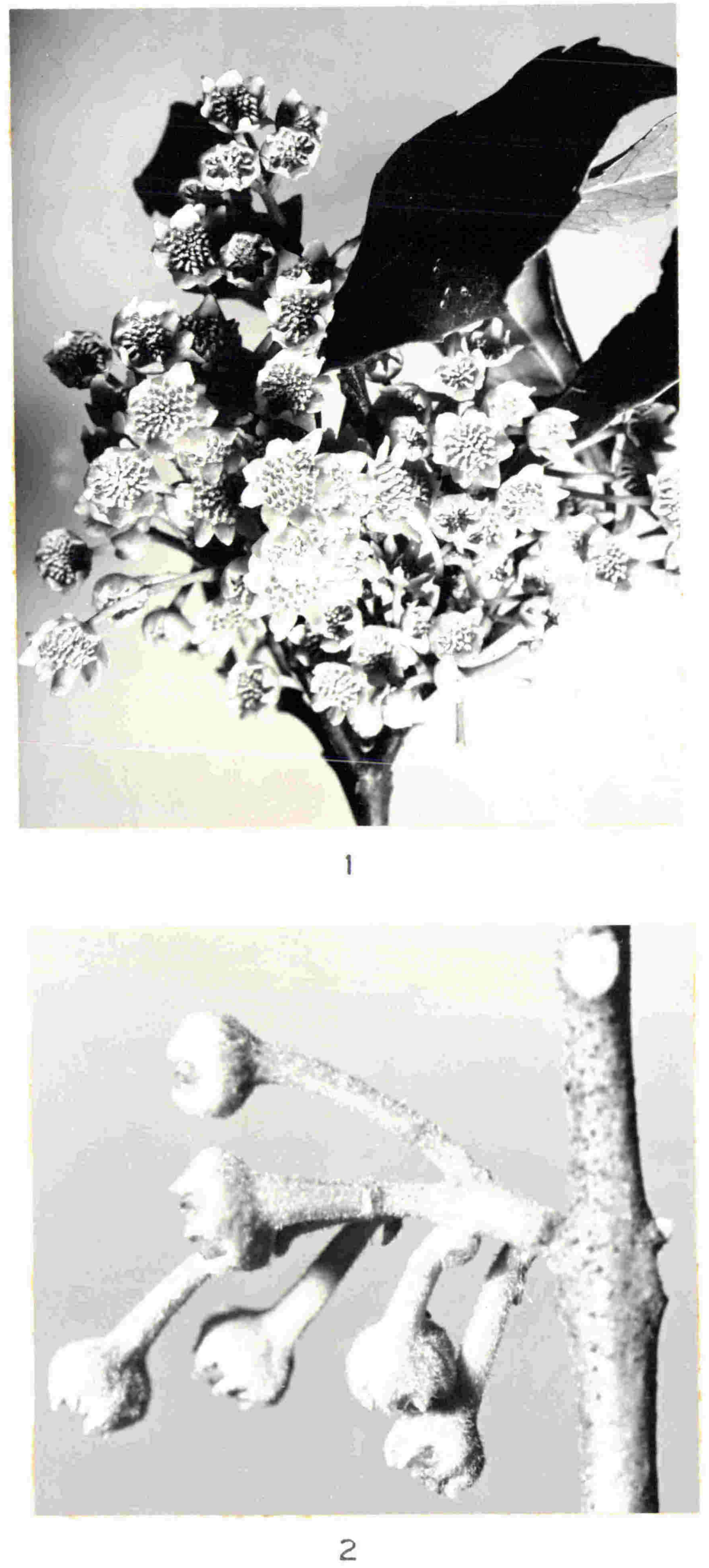


\section{PLATE 5}

Figure I Male ( lower) and car ellate flowers of Laurelia novae-zelandiae. Male flower bud at left. Photo Prof. J.I.Salmon . x 3

Fisure? Male flower of Hedycarya arborea ( preserved in f.a.a. ). Fhoto M.D.IIing. x 5

Fisure 3 Partly-open male flower of Hedycarya arborea. x 7 $p=$ reduced tepal

Figure 4 Wale flower of Laurelia $\underline{n} \cdot \underline{z}$. ( preserved in f.a.a. ). Photo I.D. King. $x 7$

Fisure 5 Carpellate flower of Laurelia $\underline{\text { n.z. }}$. (preserved in f.a.a.). Ploto M.D.King. x.8 

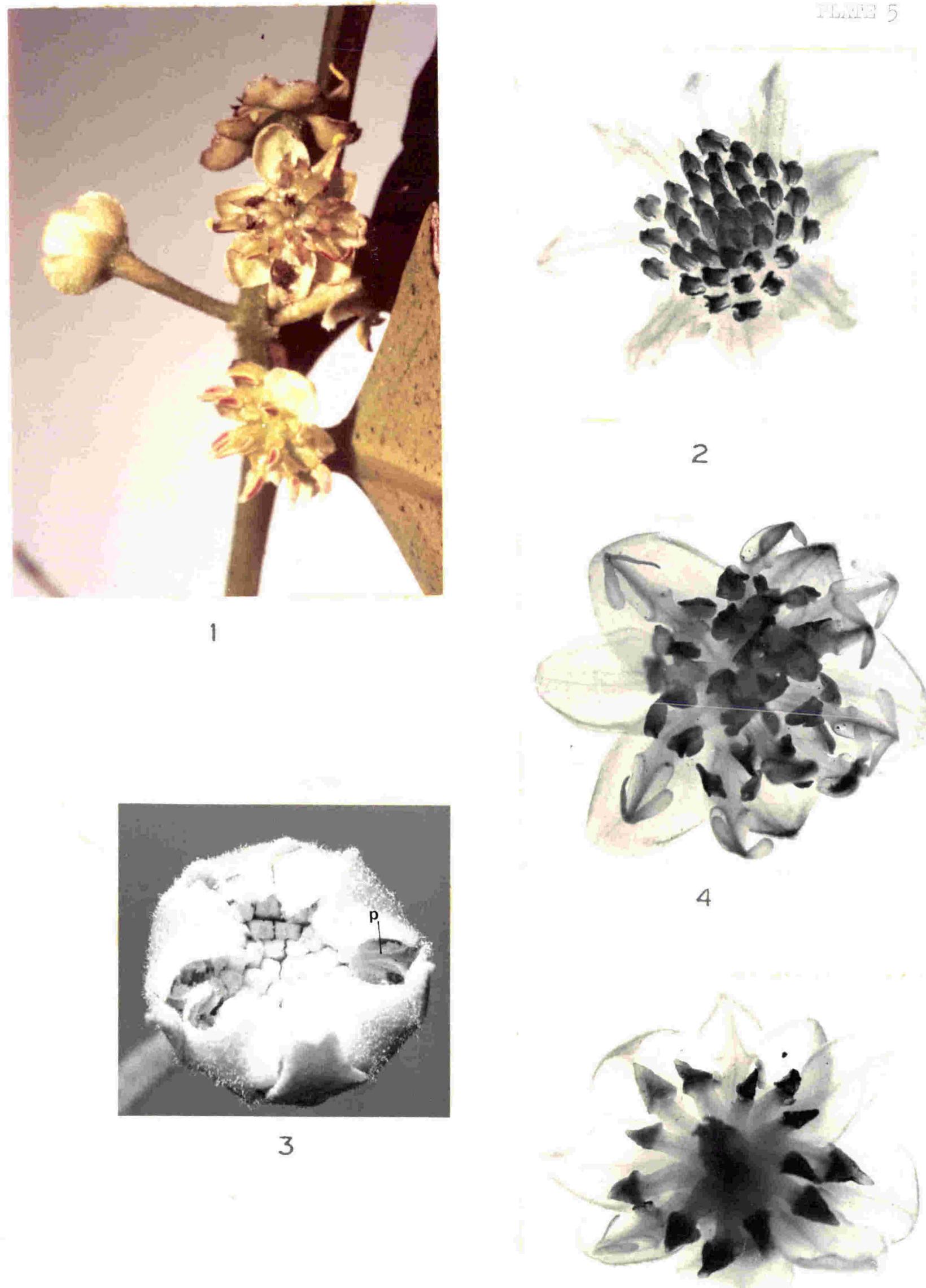


\section{PLATE 6}

Figure 1 Mature pseudocarps on Laurelia $\underline{n} \cdot \underline{z} . \quad x 1.5$

$$
t=\text { tepal }
$$

Figure 2 Nature fruits of Hedycarya arborea ( somewhat abnormally shrivelled). x 1.5

$$
t=\text { tepal }
$$



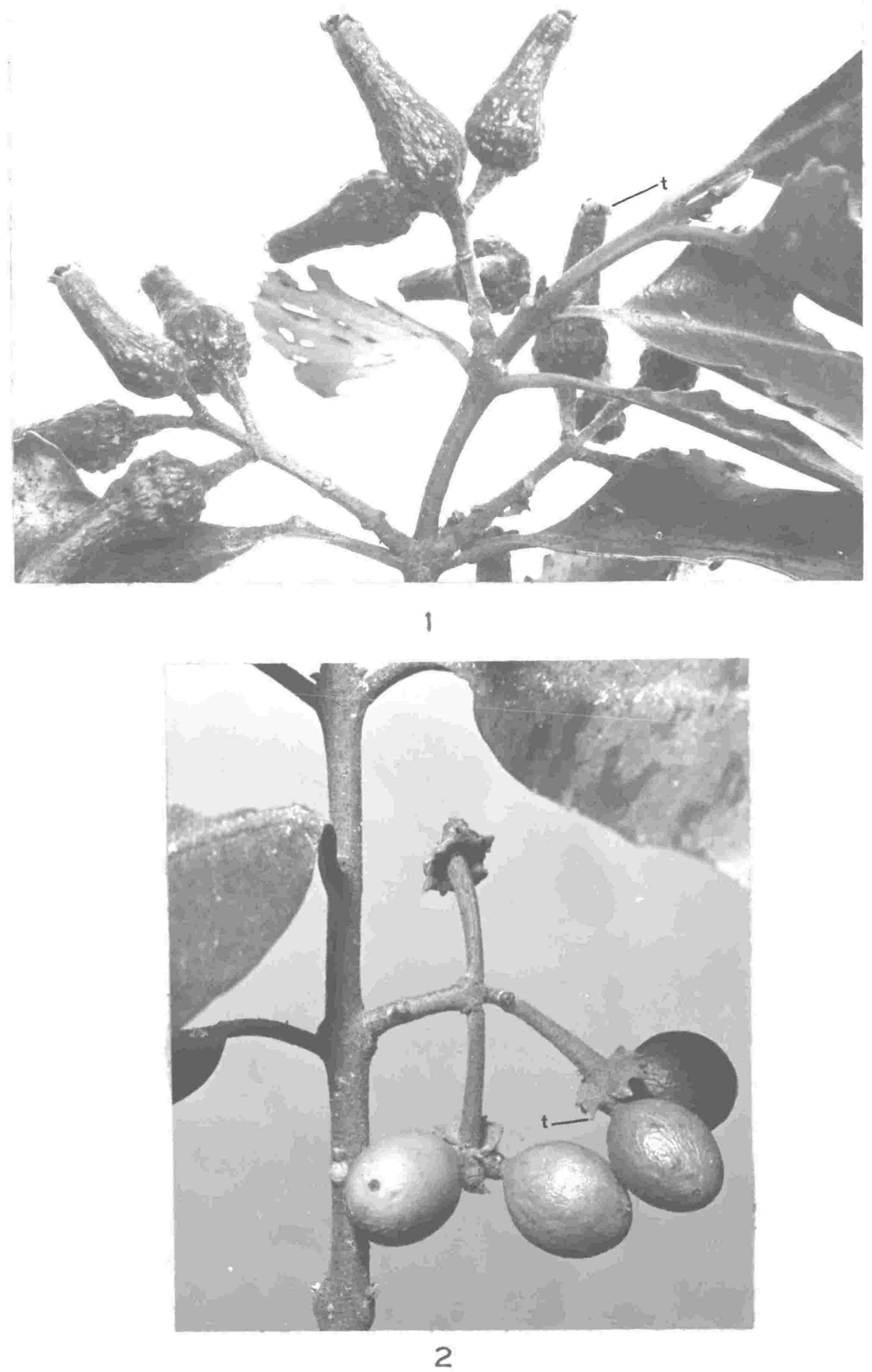


\section{PLATE 7}

Cleared bracts and tepals, as seen in adqxial face view, to show their vascularization.

Figures 1 - 8 Tepals from carpellate flowers of Laurelia $\underline{\underline{n}} \cdot \underline{\underline{z}}$.

Figures 2-10 Bracts of Laurelia $\underline{\text { n. }}$.

Figures $11-18$ Tepals from female Hedycarya arborea flowers.

Figures $12-21$ Bracts from inflorescences of Hedycarya arborea. 
PLATE 7
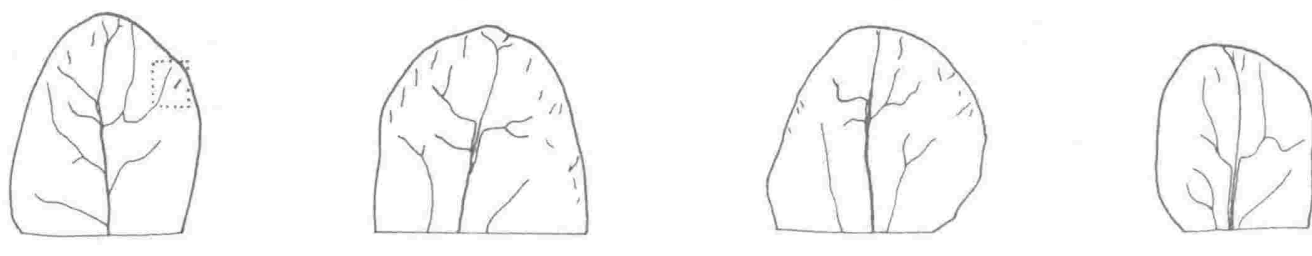

1

2

0

$2 \mathrm{~mm}$.

3

4

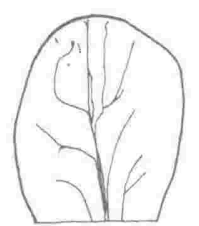

5

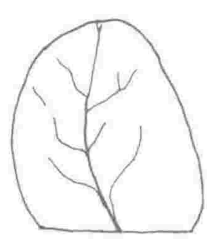

6

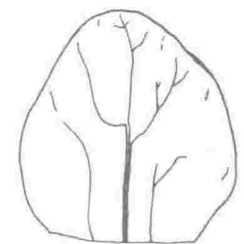

7

Laurelia tepals
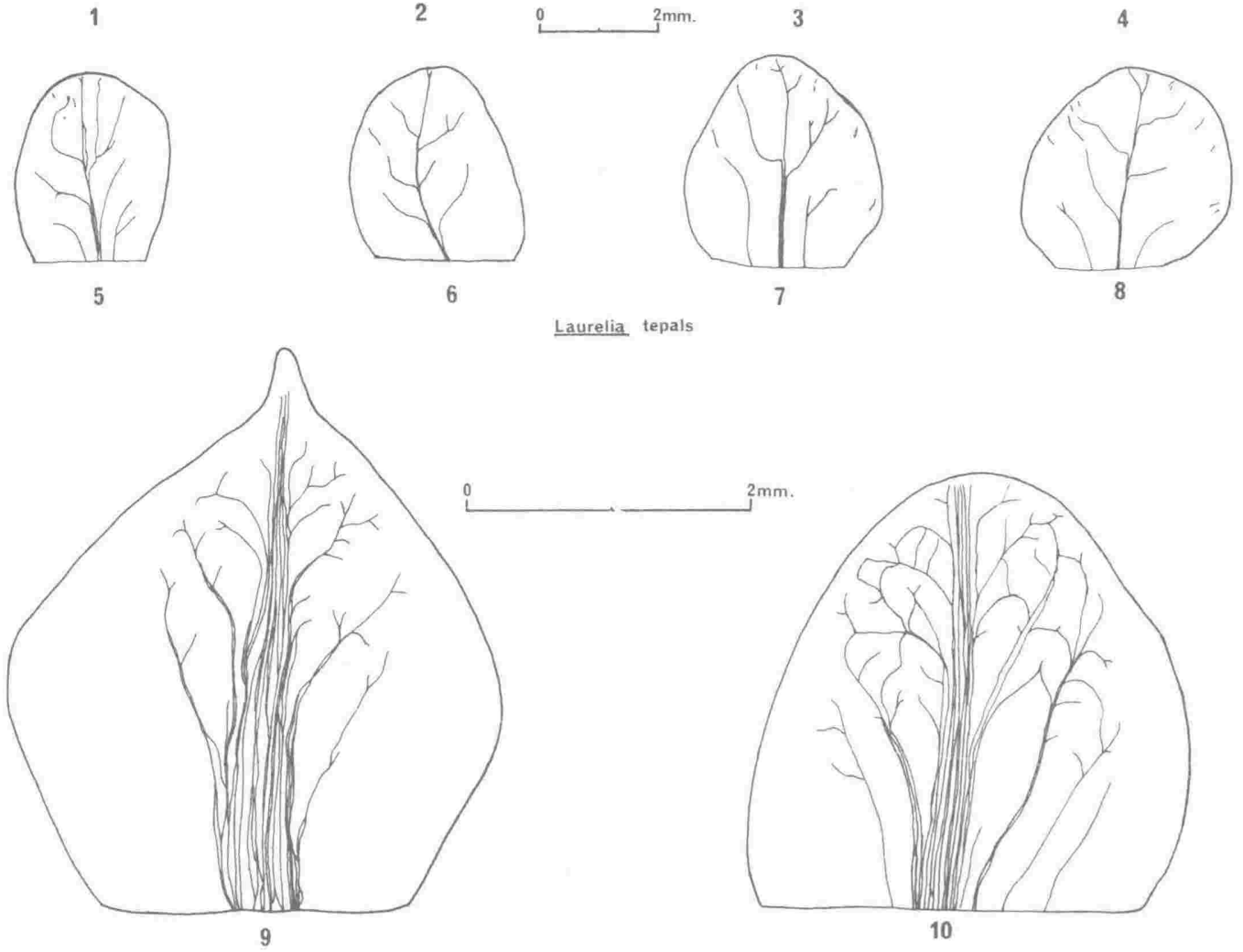

$\underline{\text { Laurelia bracts }}$

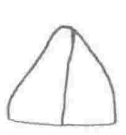

11

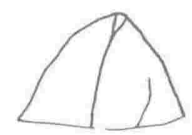

12

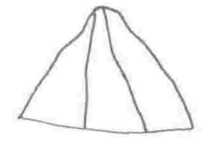

13

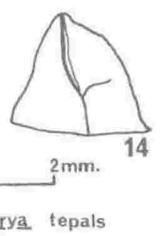

Hedycarya tepals

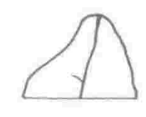

15

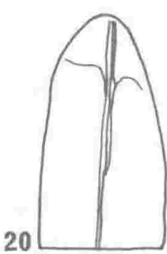

$2 \mathrm{~mm}$.

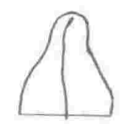

16

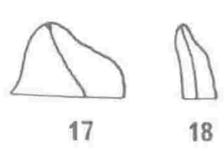

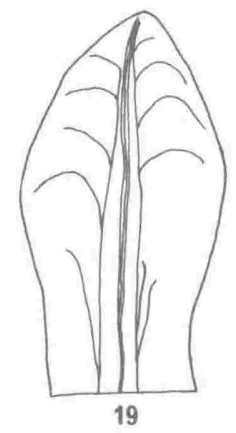

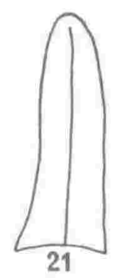

Hedycarya bracts 


\section{PLATE 8}

Figure I Photomicrograph of portion of a cleared tepal of Laurelia novae-zelandiae. A lateral vascular trace can be seen at left and an isolated trace at right centre. This photo represents the area enclosed by the dotted line in the tepal illustrated in fig. 1, PLATI 7. $\times 135$

Figure 2 A more magnified view of the isolated trace in figure 1. This photo has been mounted upside down in comparison to figure 1 of this plate. x 470 


\section{PLATE 9}

Cleared stamens and staminodes of Laurelia novae-zelandiae showing their vascularization. Further details in text. 

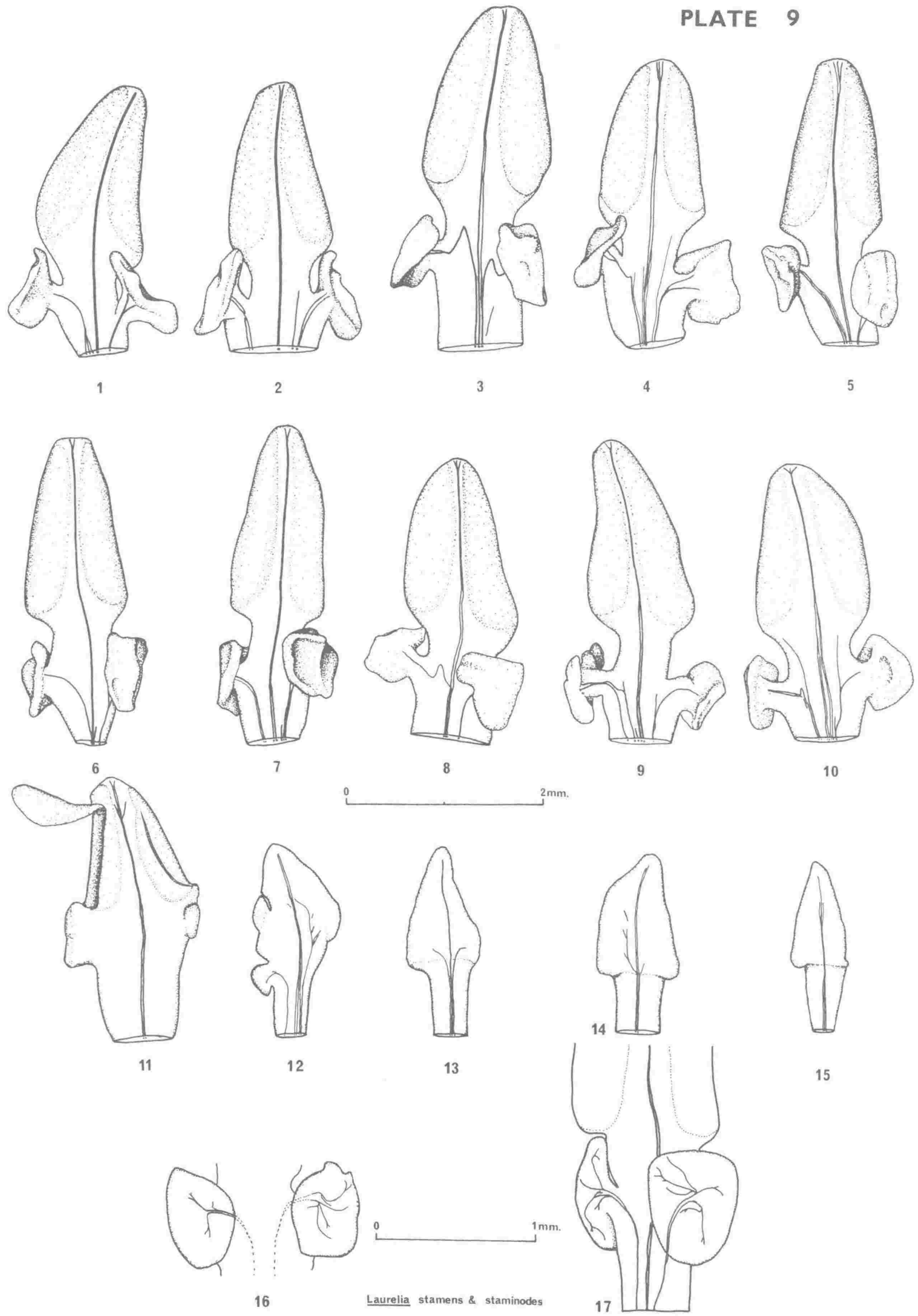
PLATE 10

Figures 1-6 Cleared carpels of Hedycarya arborea, showing their vascularization. In figures 1 and 3 , the broken line indicates the position of the ovule. Dotted lines in the other figures show the position of locules and ovules.

Figure 7 Cleared sterile carpel of Hedycarya arborea.

Figures 8-9 Cleared carpels of Laurelia $\underline{\text { n.z. }}$. , showing vascularization. Dotted lines indicate the extent of the ovule and locule.

$$
\begin{aligned}
s-t & =\frac{\text { level above which stigmatic surface }}{\text { begins }} \\
o & =\text { ovular trace } \\
d & =\text { branch of dorsal trace }
\end{aligned}
$$



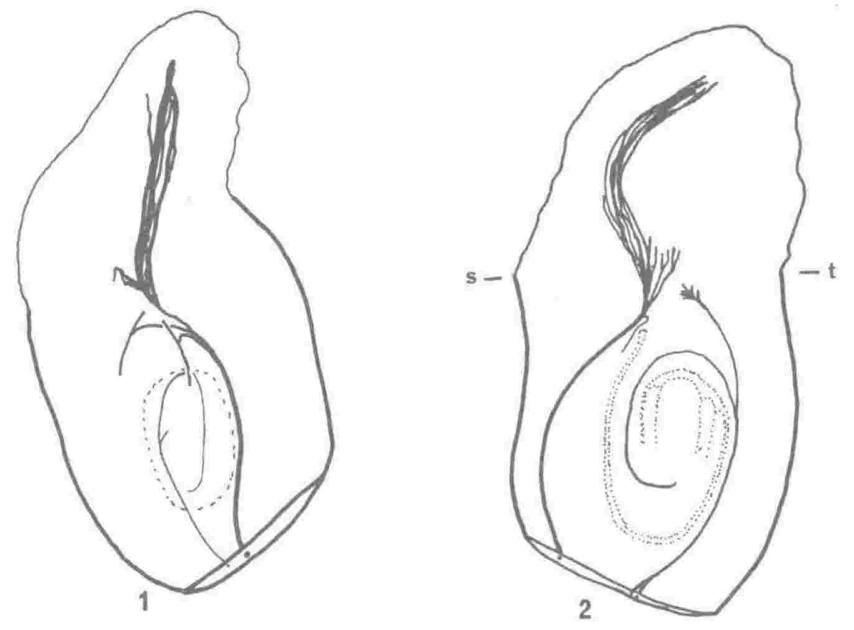

PLATE 10
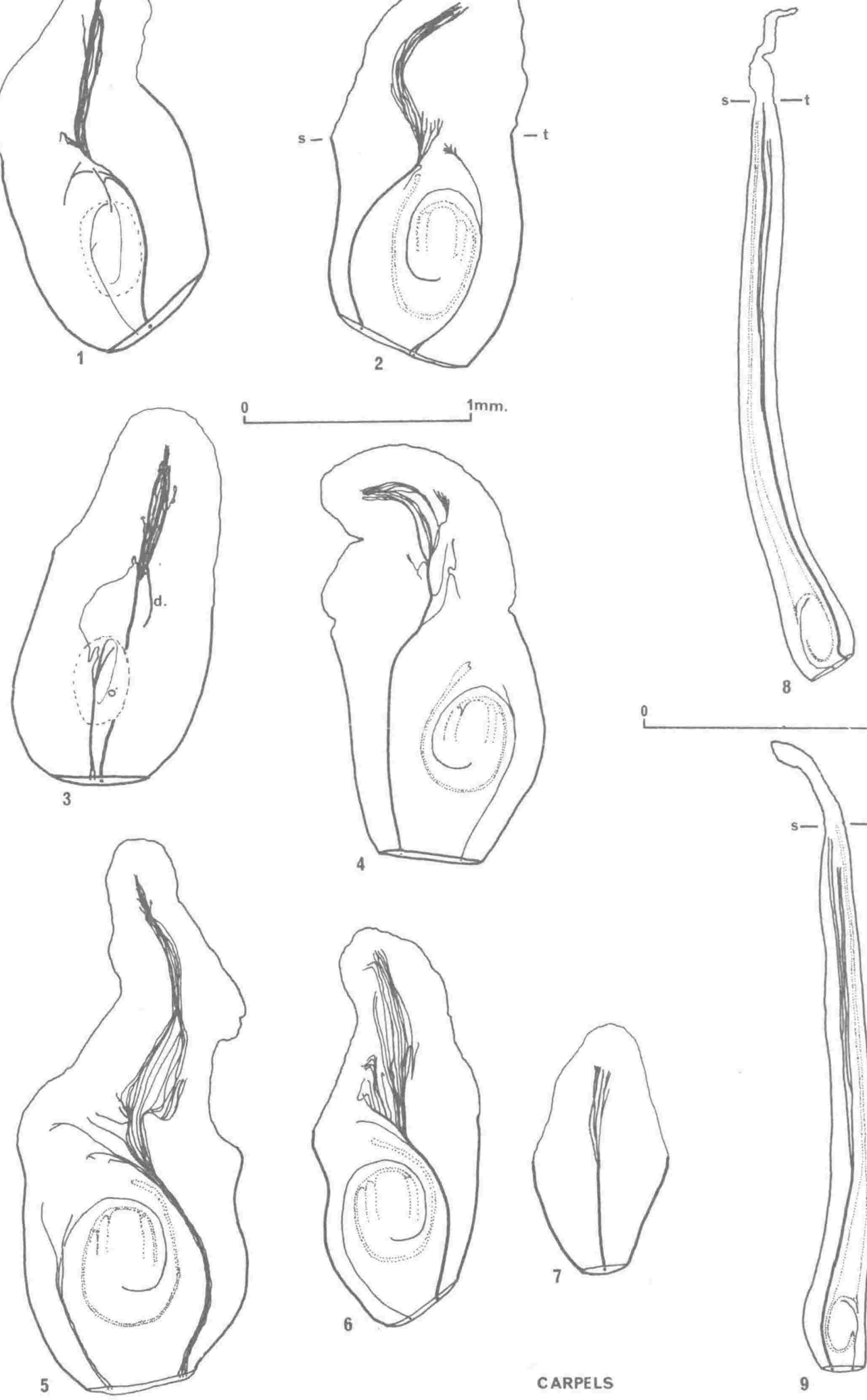

CARPELS

$1 \mathrm{~mm}$.

Hedycarya

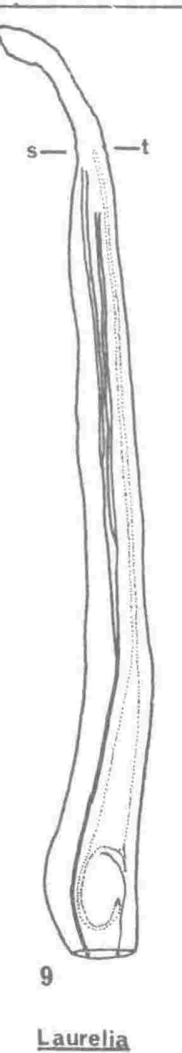


Cleared male flower of Hedycarya arborea in which the stamens have been removed. Dotted and broken lines indicate the position of insertion of stamens on the receptacle. For simplicity, traces are only shown entering the bases of those stariens which are indicated by dotted lines. Further details in text. 


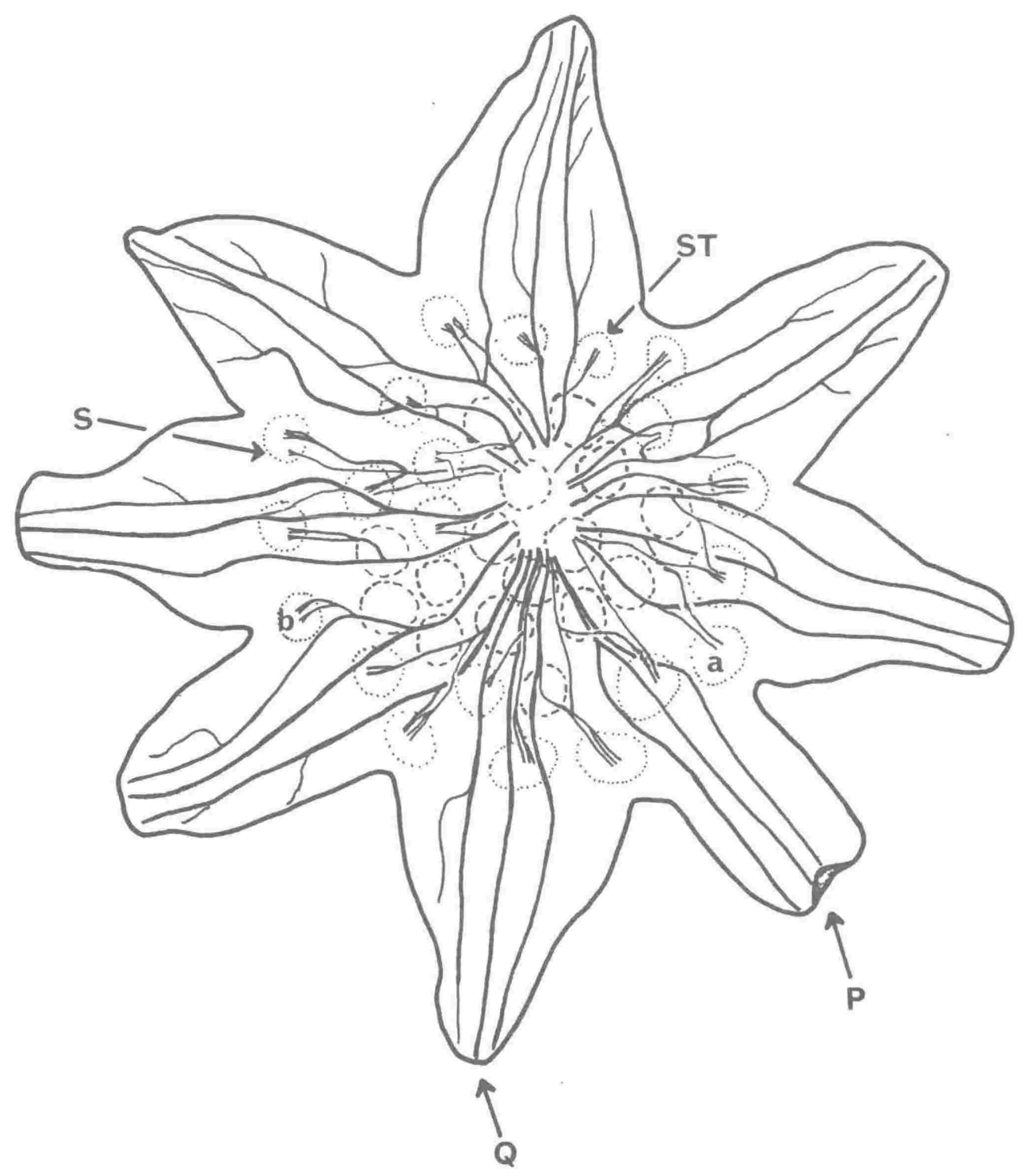

Hedycarya - male flower

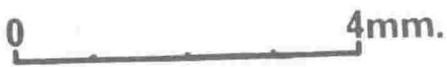




\section{PLATE 12}

Figure 1 L.s. stamen of Hedycarya arborea at a stage at which sporogenous tissue is present. $x 105$

Figure 2 Longitudinally bisected carpellate flower bud

of Laurelia novae-zelandiae, shortly before anthesis. An ovule has been exposed in the carpel at left. Photo M.D.King. $\quad$ x 15

Figure 3 Apical view of female flower of Hedycarya arborea. Photo M.D.King . $\times 11$

$$
c=\text { sterile carpel }
$$



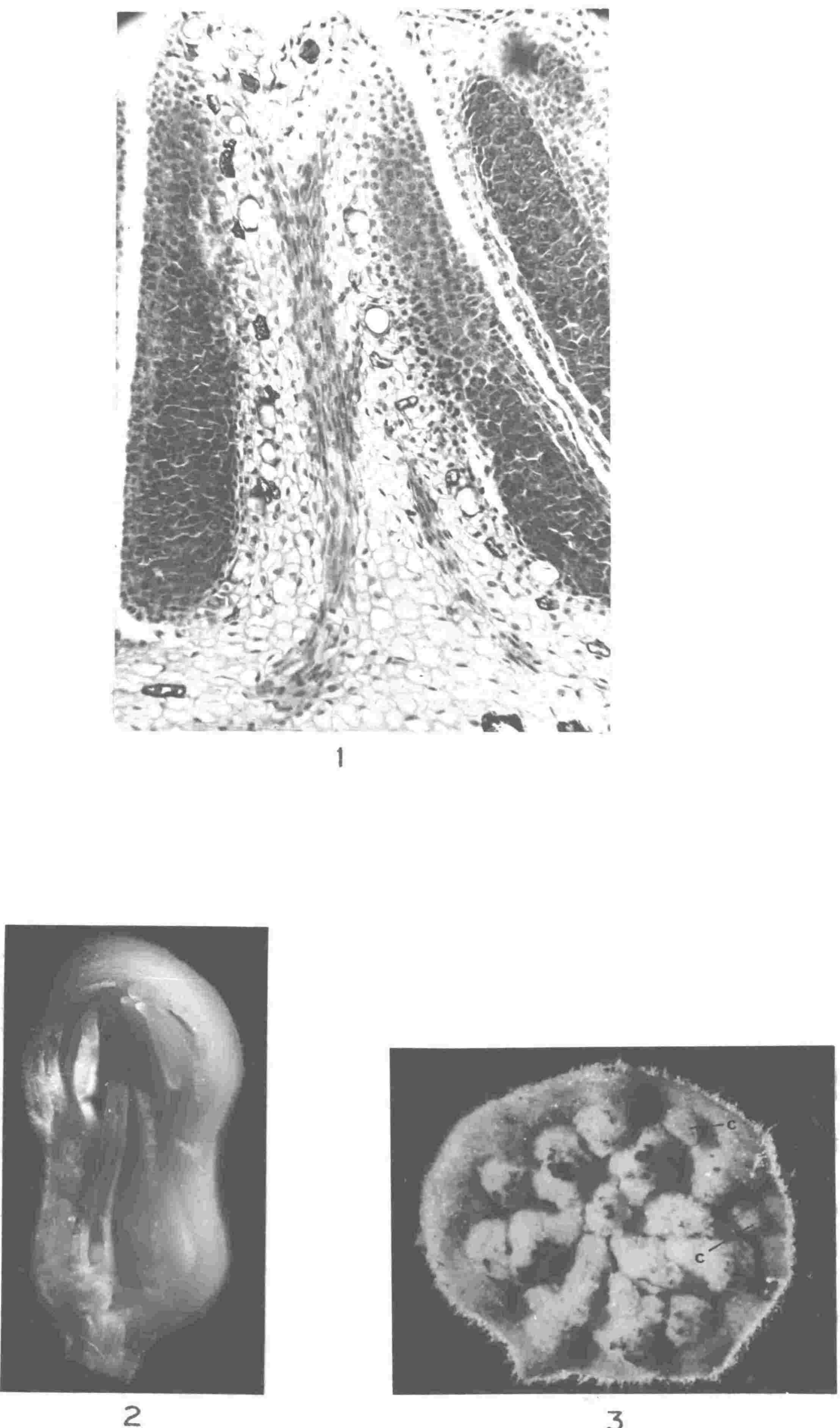
PLATE 13

Figure 1 Male flowers of Atherosperma moschata. $x 3$

Figure 2 Carpellate flowers and flower buds ( above) of Atherosperma moschata. $\times 3$

$$
\mathrm{br}=\mathrm{a} \text { pair of bracts }
$$

Figure 3 Flower of Doryphora sassafras. $\quad$ I 3 


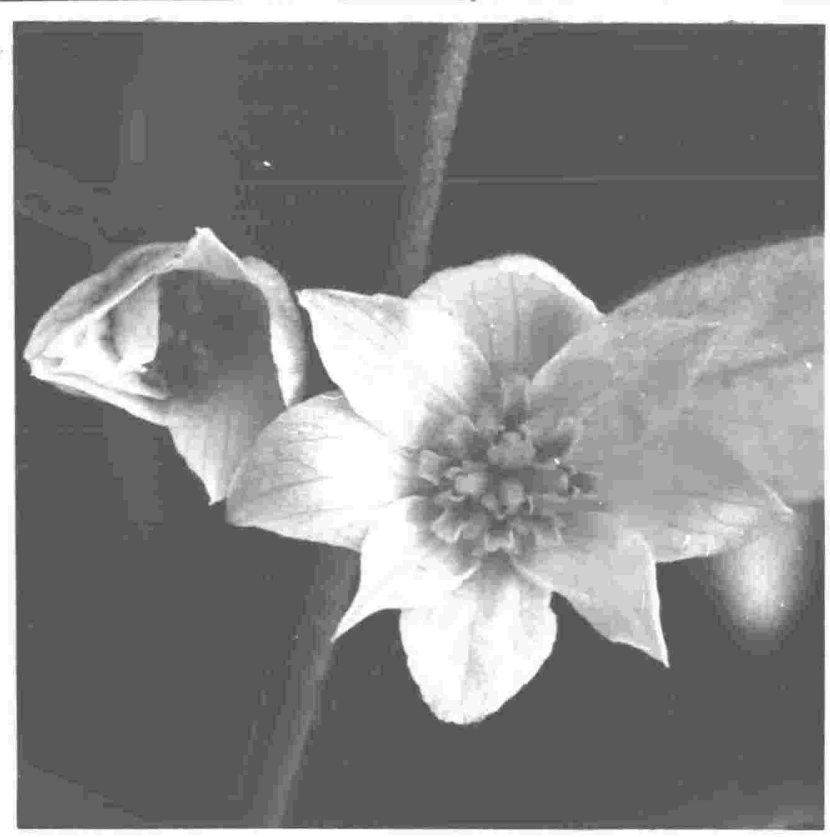

1

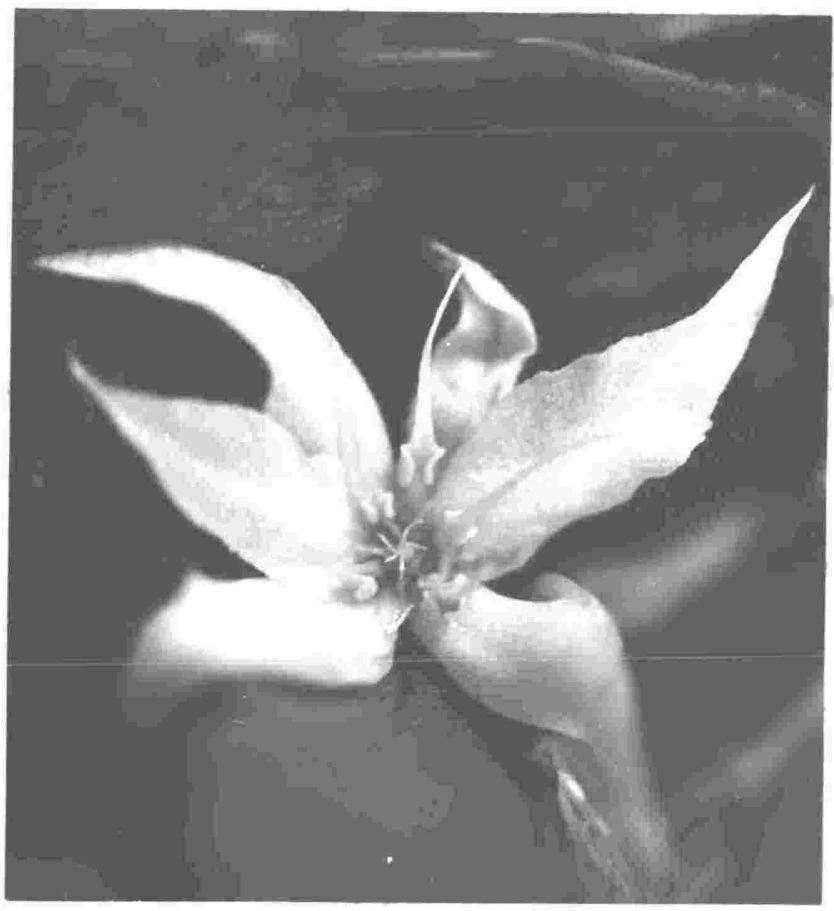

3

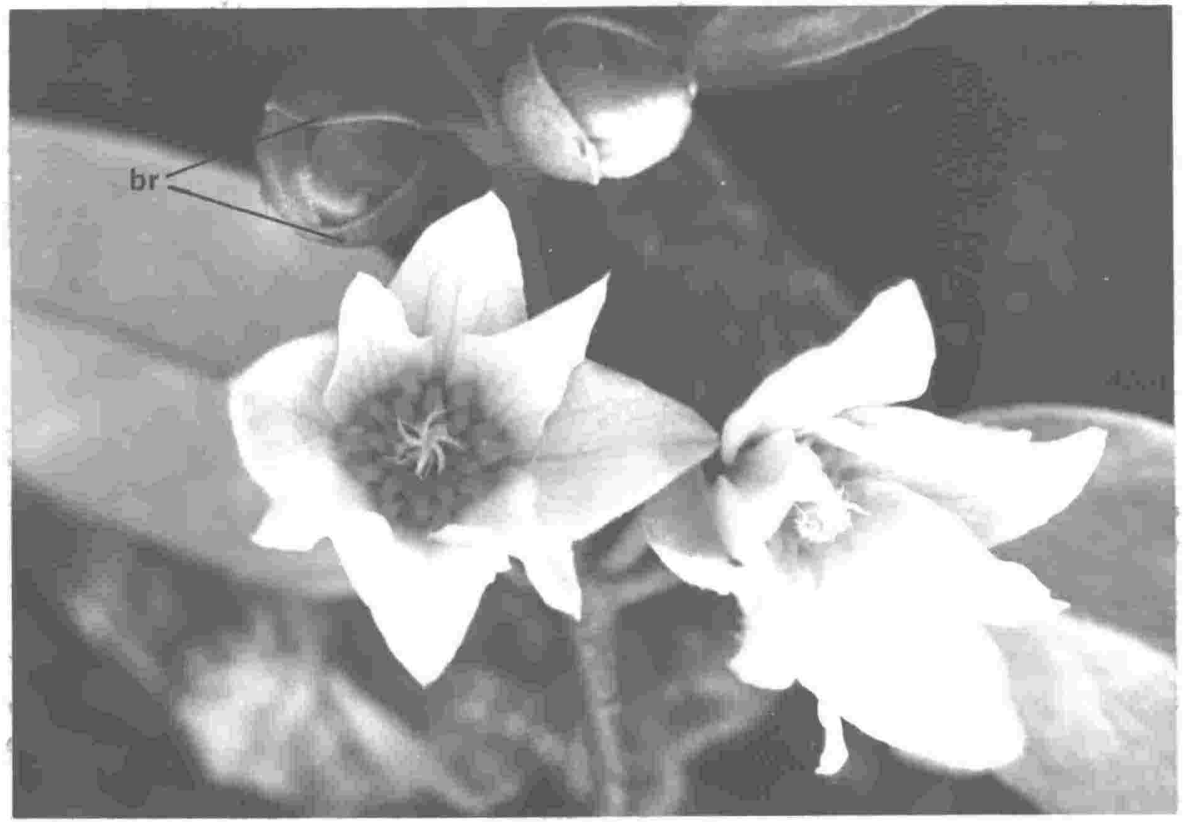

2 


\section{PLATE 14}

Figuxe 1 Median 1.s, of a terminal bud of the shoot of a female Hedycarya arborea plant. $\quad$ × 40

Figure 2 Median 1.s. of a terminal bud of the shoot of Laurelia

n.z. $\quad x 40$ 

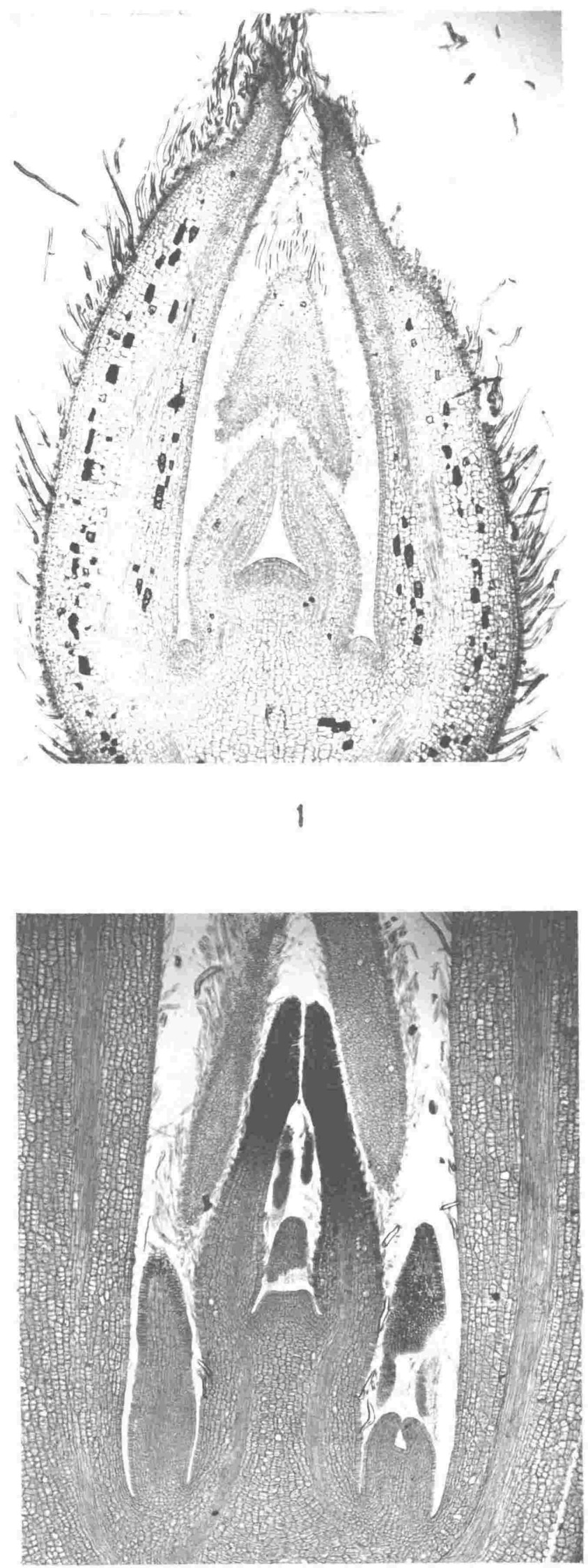
Figure 1 A more magnified view of the apical meristem of Hedyoaxya, shown in fig. 1, PLATE 14. × 240

Higure 2 L.s. of the vegetative shoot apex of Hedycarya arborea ( female plant) at a stage somewhat beyond minimal surface area. x 250 

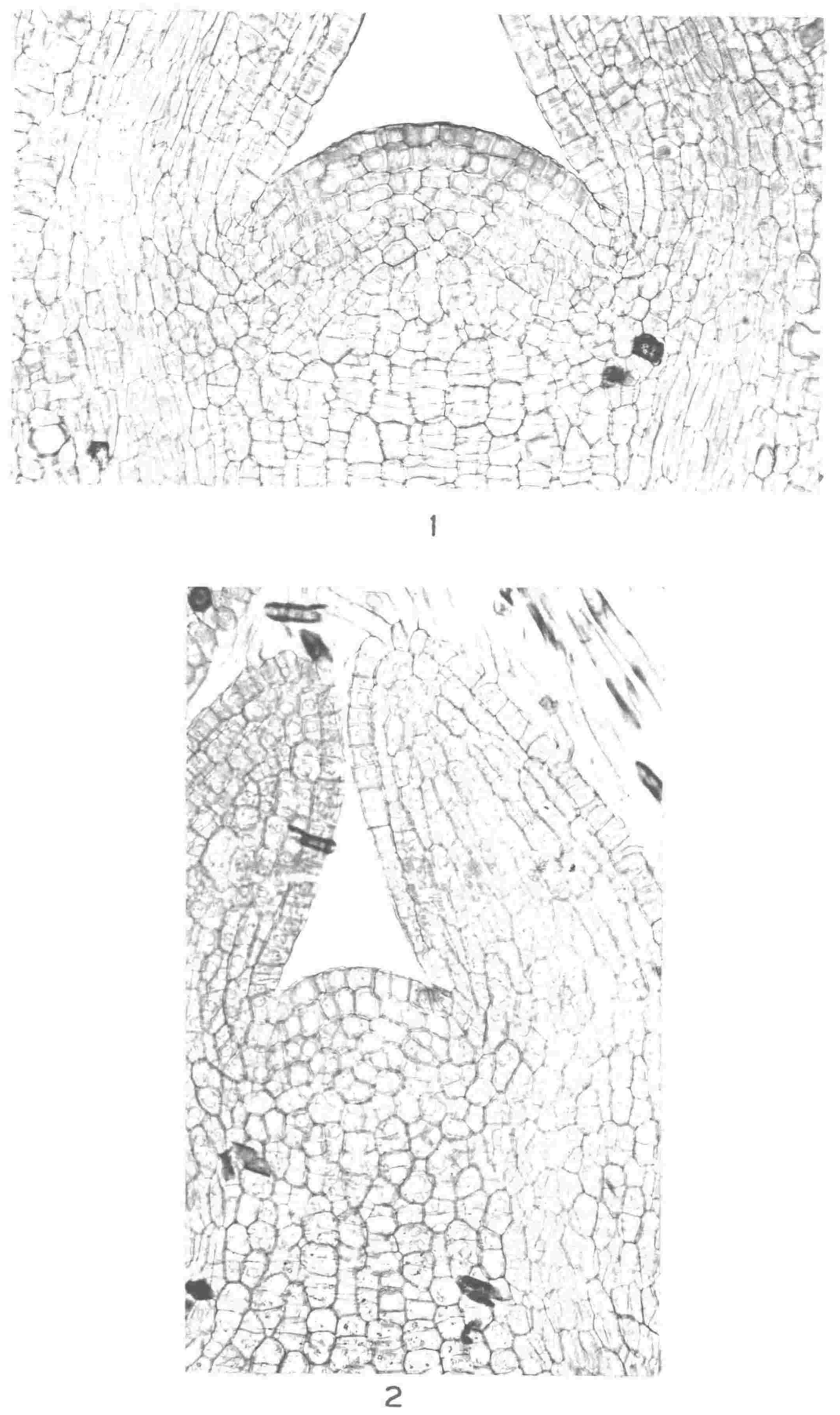


\section{PLATE 16}

Figure 1 T. 1 . of part of a terminal shoot bud of Hedycarya arborea (female plant), with the apical meristem at centre enclosed by two pairs of leaf primordia. $x 250$

Figure 2 A more magnified view of the apical meristem of Laurelia, shown in fig. 2, PLATE 14. x 250

Figure 3 Median 1.5. of the vegetative shoot apex of Laurelia

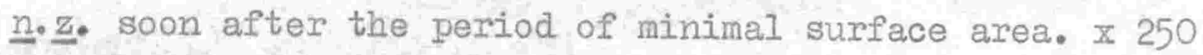




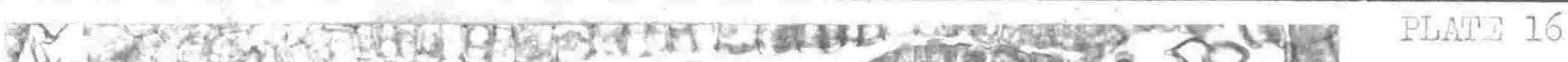

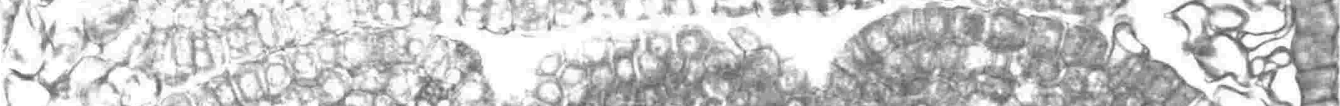
T-9.

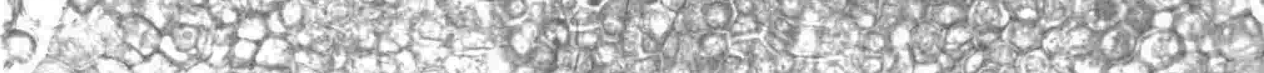

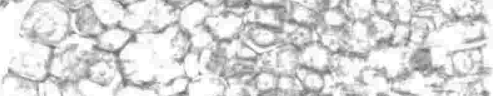

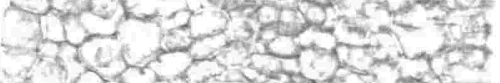

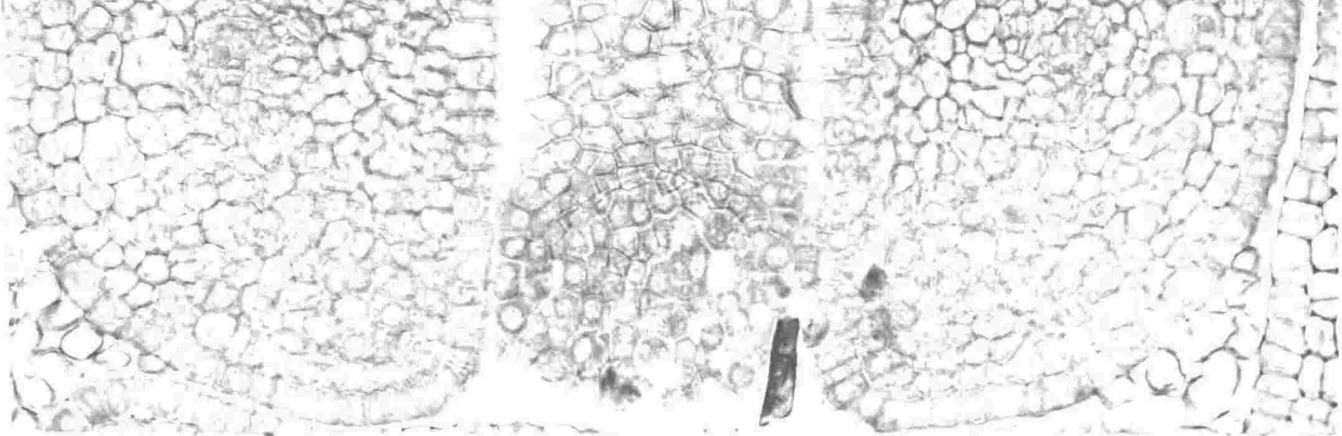

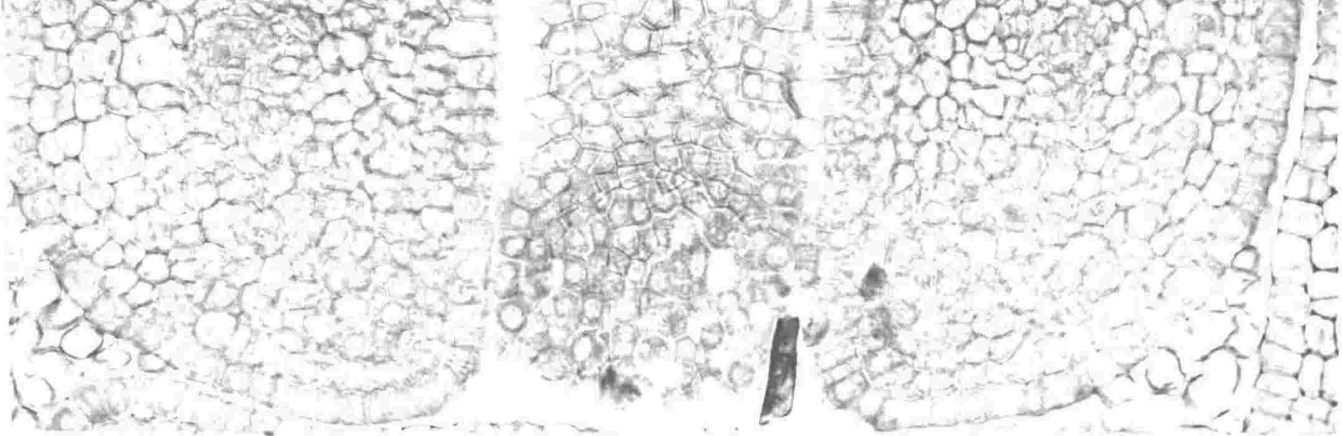

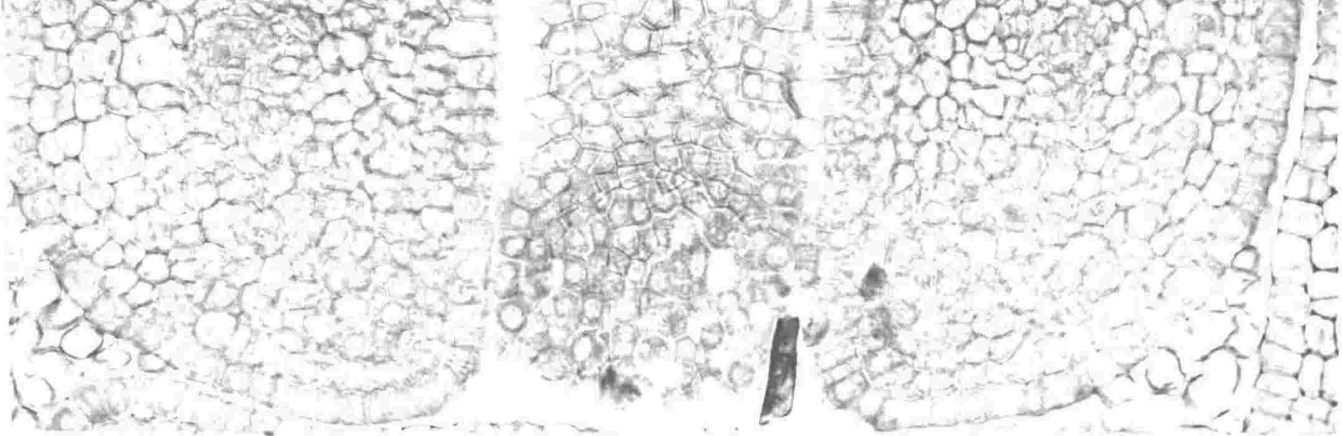
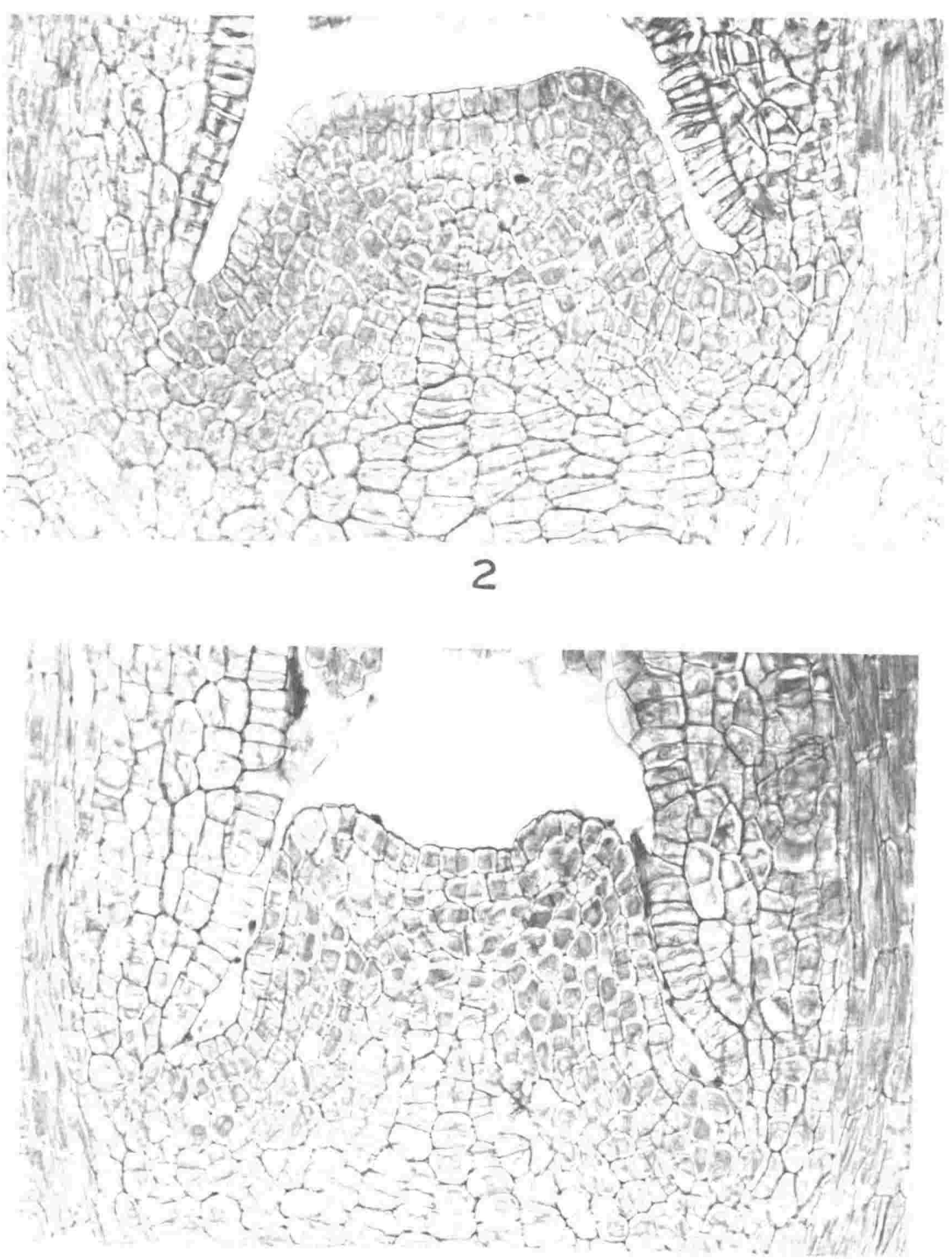


\section{PLATE 17}

Figure 1 L.s. of the vegetative shoot apex of Laurelia $\underline{\text { n.z.z. }}$ × 250

Figure 2 A more magnified view of the putative inflorescence apex of Hedycarya arborea, shown in fig. 1, PLATE 14. x 250 

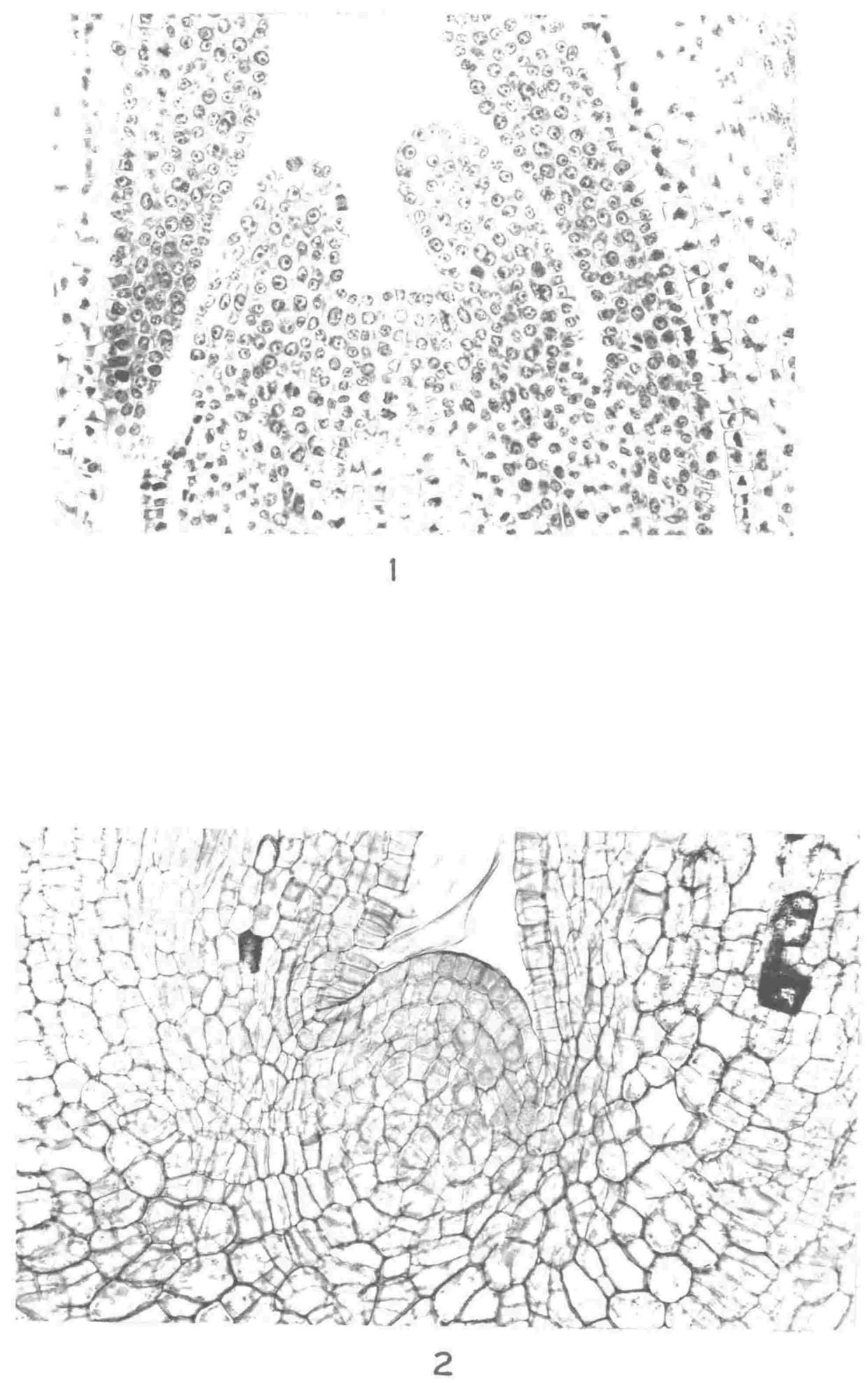


\section{PLATE 18}

Figure 1

A more magnified view of the putative young inflorescence bud of Laurelia, shown in fig. 2, PLAT 14. x 250

Figure 2 Median 1.S. of a young female inflorescence apex of Hedycarya arborea. $\quad$ × 200 


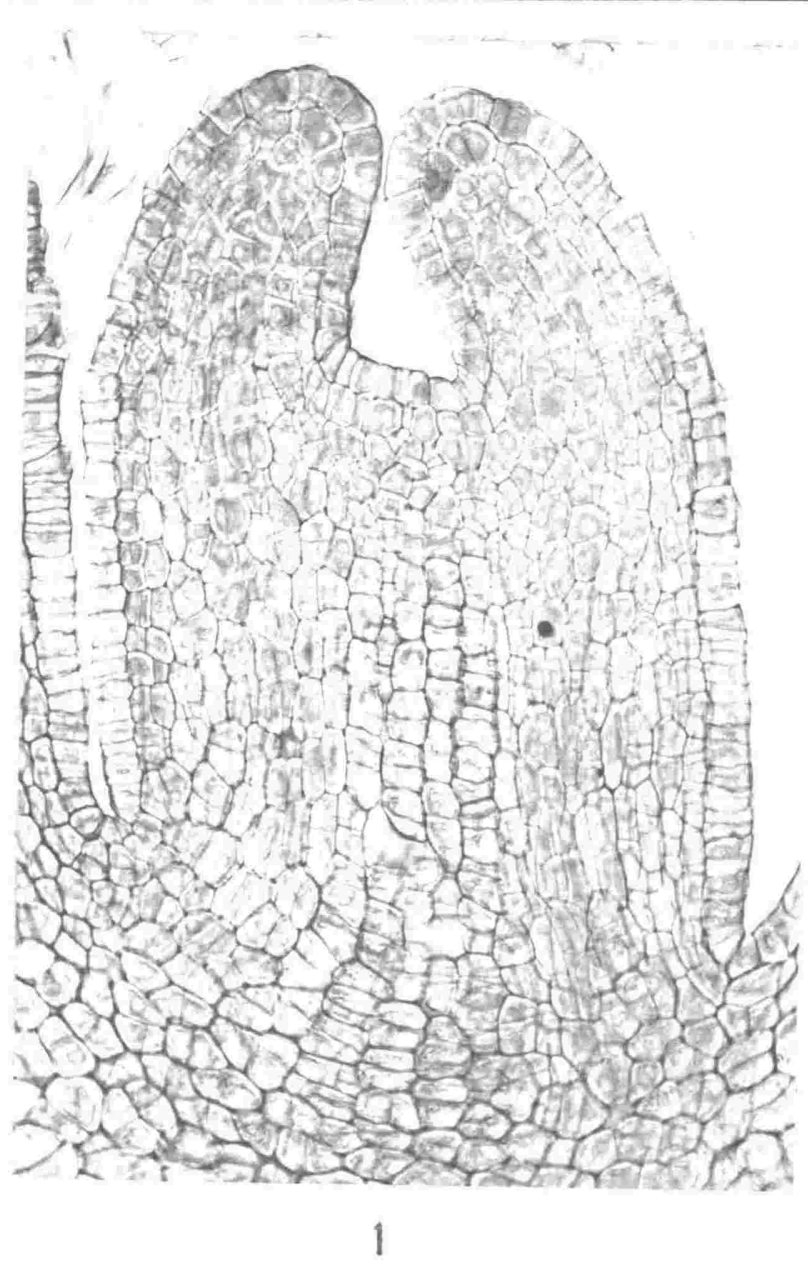




\section{PLATE 19}

Fisure 1 Median 1.5, of an inflorescence apex of Laurelia $\underline{\text { n. }}$. x 300

Figure 2 L.S. of part of a female inflorescence bud of Hedycarya arborea with the inflorescence meristem at left and a floral apex at lower right. $\times 115$ 


\section{PLATE 20}

Figure 1 Median 1.s. of a young female inflorescence apex. of Hedycarya arborea - x 212

Figure 2 Median 1.s, of a young floral apex of Laurelia n. The inflorescence axis is on the right side of the photo. $\times 460$

$$
\mathrm{s}=\mathrm{a} \text { cell of the"shell zone". }
$$



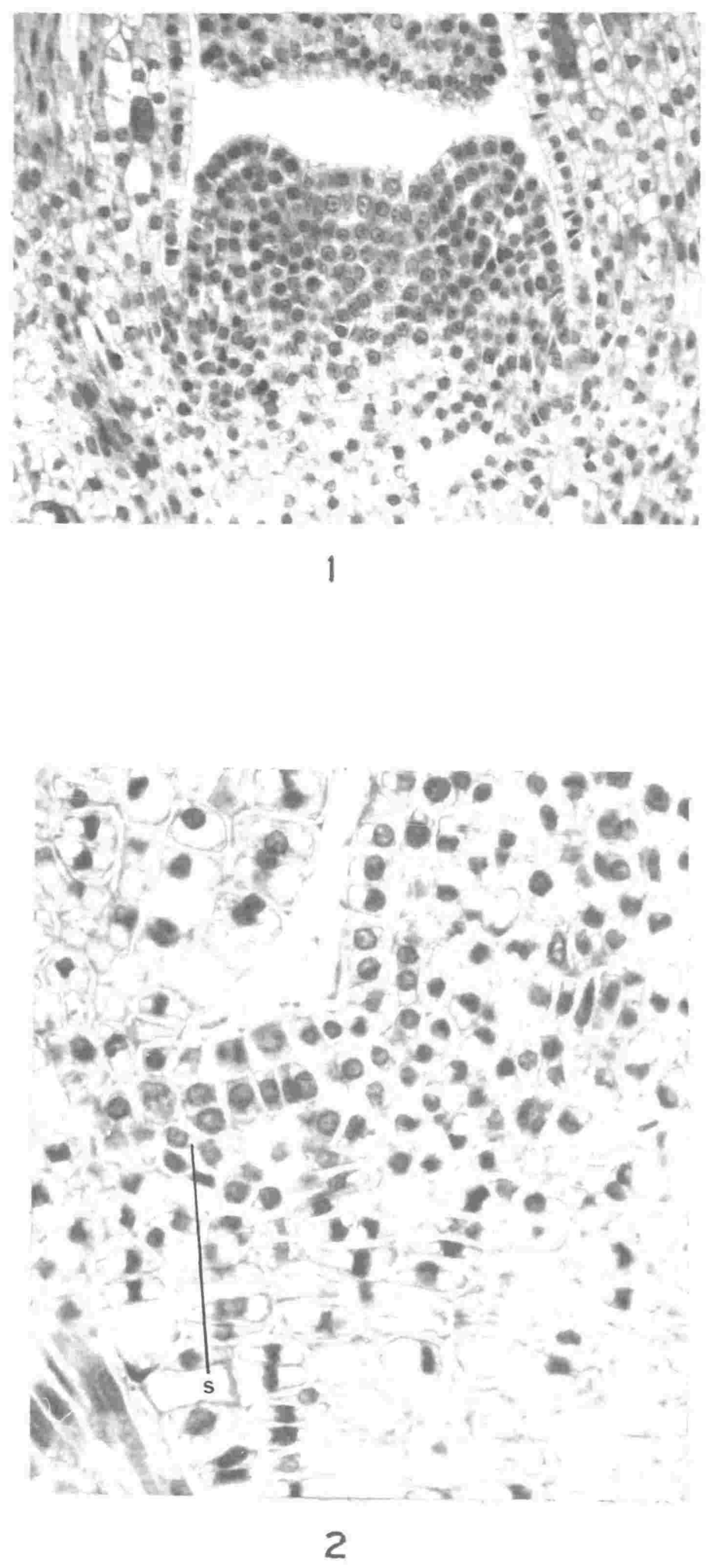
PLATE 21

Figure 1 Median 1.s, of a young male flower bud of Hedycaxya arborea, with tepal primordia. $\times 280$

Figure 2 Median 1.s, of a young male floral apex of Hedycarya arborea. $\quad \times 310$ 

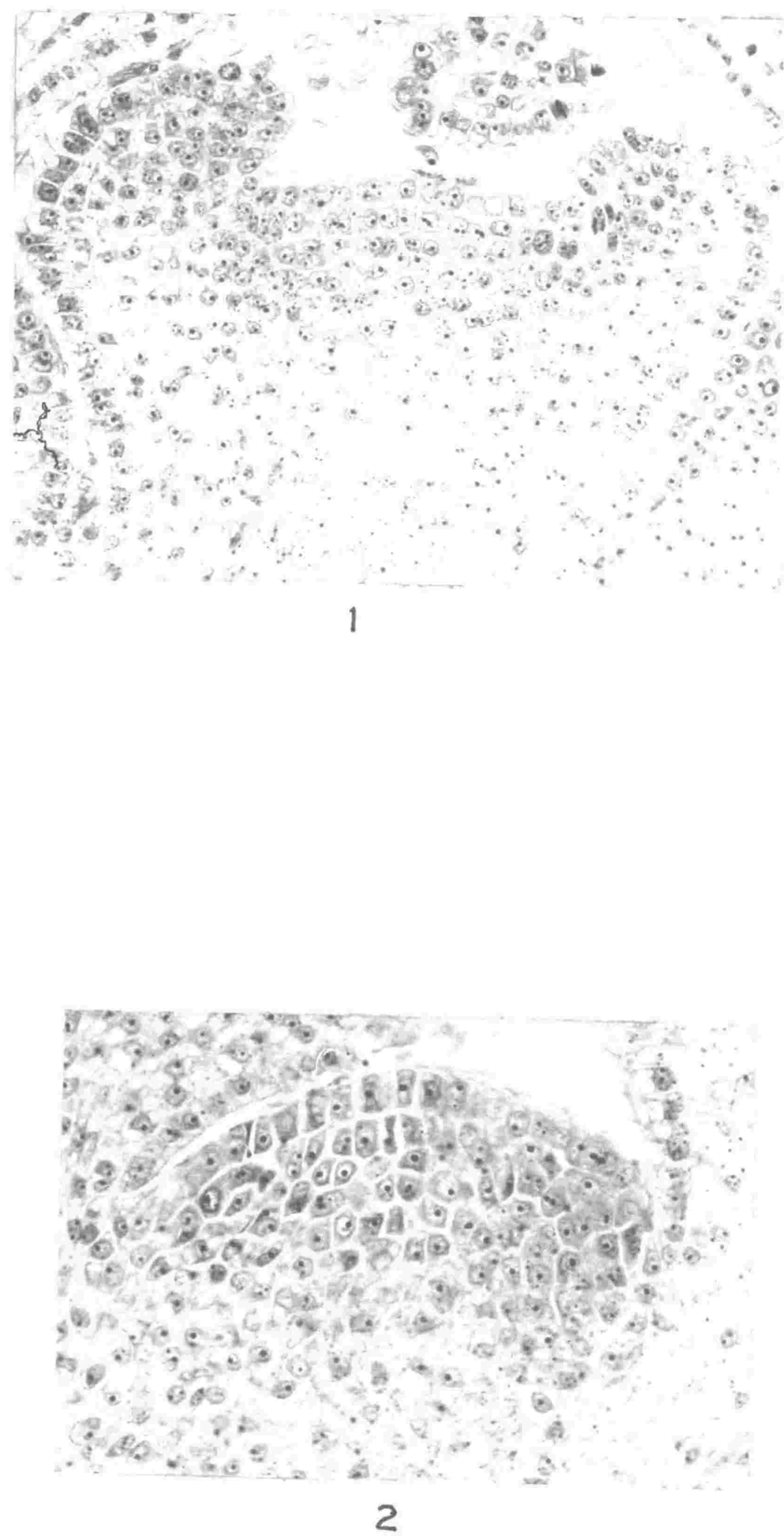


\section{PLATE 22}

Figure 1 L.s. of a female flower bud of Hedycarya arborea in which the outermost carpels are being initiated. x 210

Figure 2 Median l.s. of the floral apex of a male flower of Hedycarya arborea near the end of stamen initiation. Three stamen primordia are visible. x 200 

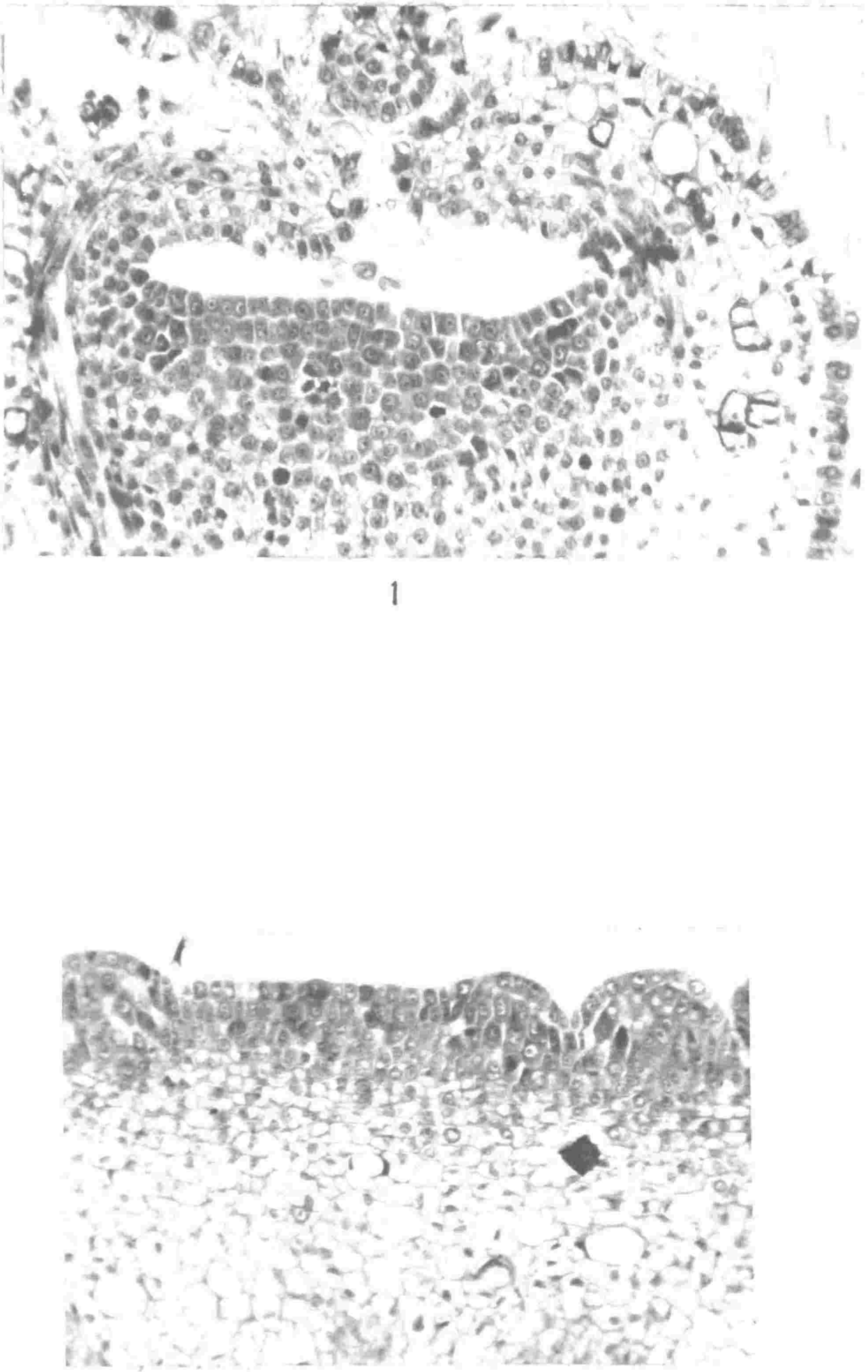


\section{PLATE 23}

Figure 1 Median 1.s. of the floral apex of a male flower bud of Hedycarya arborea, near the end of stamen initiation. $\times 385$

$\mathrm{v}=$ vacuolate cell undergoing division

Figure 2 Median l.s. of the floral apex of a female flower bud of Hedycarya arborea, near the end of carpel initiation. x 130

$t=$ young trichome 

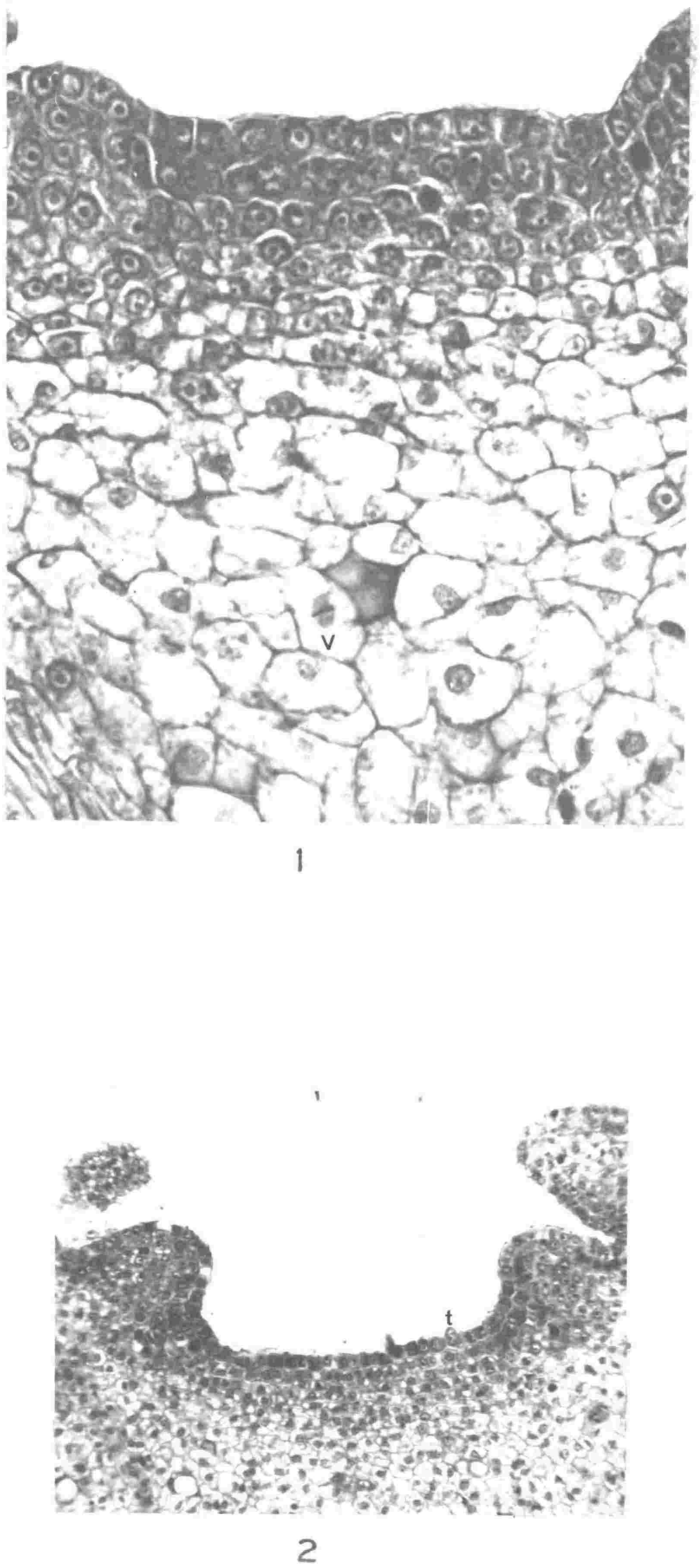


\section{PLATE 24}

Figure 1 Nedian 1.s. of part of a female flower bud of Hedycarya arborea. A large vestigial floral apex is present and is flanked by carpel primordia. $\times 125$

Figure 2 Median 1.s. of part of a female flower bud of Hedycarya arborea. A vestigial floral apex is flanked by carpel primordia wich are older than those shown in figure 1. x 140 $m=a$ vacuolate cell undergoing anticlinal division 

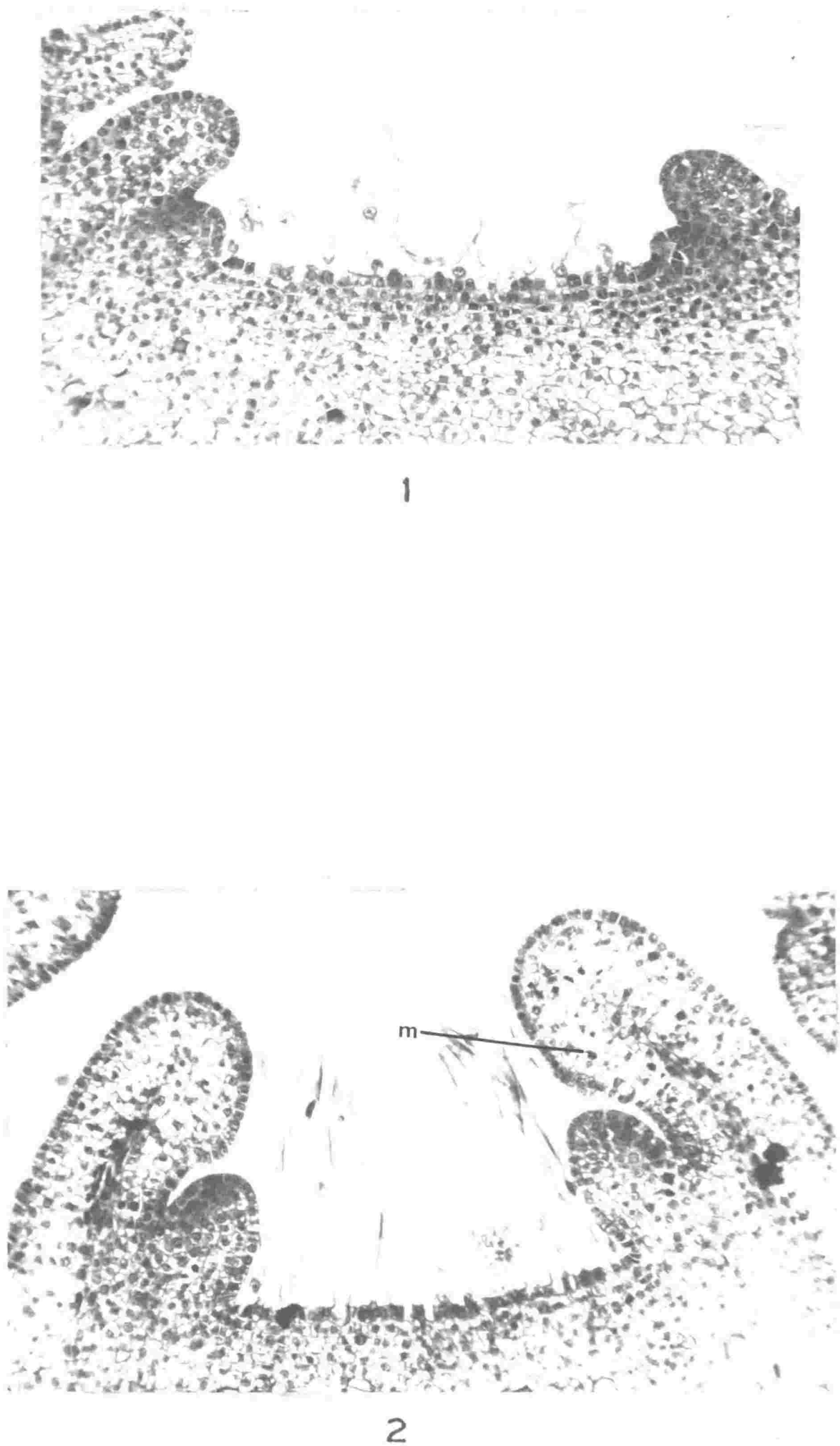


\section{PLATE 25}

Figure 1 L.s. of part of a carpellate flower bud of Laurelia $\underline{n}$. . In which the floral apex is flanked by carpel prinordia. x 210

Figure 2 L.s. of part of a carpellate flower bud of Laurelia n.z. in which a vestigial floral apex is present. × 210 

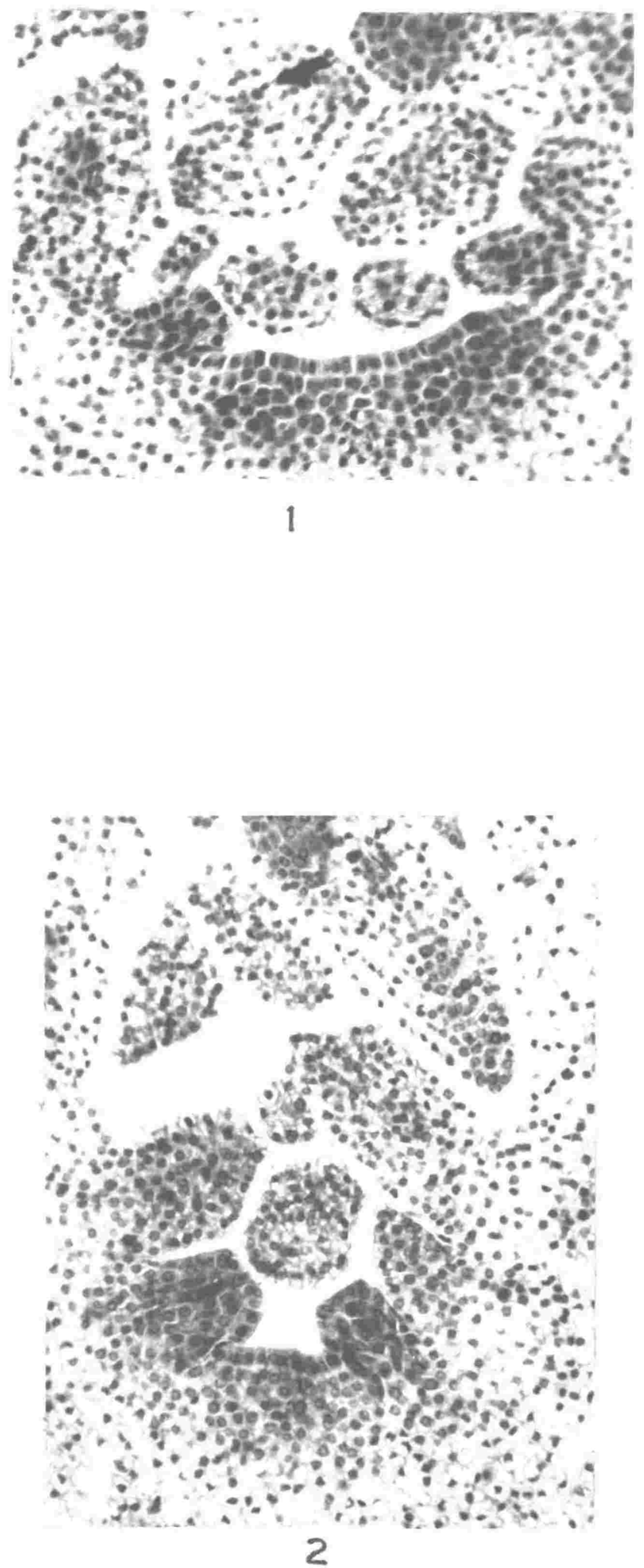


\section{PLATE 26}

Figure 1 Nature fruit of Laurelia $\underline{n} \cdot \underline{z} \cdot($ left ) and mature dmipe of Hedycarya arborea from which the epicarp and mesocarp have been removed to expose the endocarp. Photo M.D.King - x 2.7

Figure 2 Median 1.s. of a carpellate flower bud of Laurelia $\underline{n}$. . at a stage in which the outermost stamens and / or staminodes are being initiated. x 160 

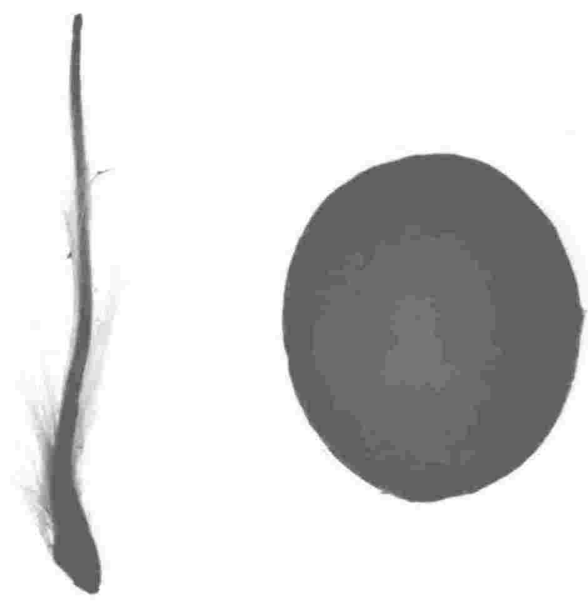

1

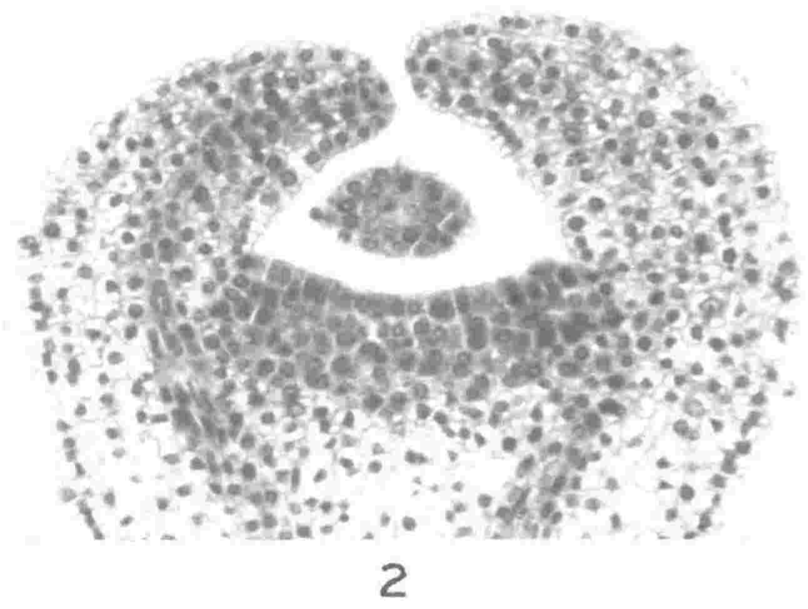


Figure 1 Young male floral apex of Hedycarya arborea in lateral and apical (b) view. The apical meristem is flanked by two bract primordia.

Figure 2 Latero-apical view of a young male flower bud of Hedycarya arborea showing the apical meristem flanked by four tepal primordia. The bracts have been excised at their bases (B).

Figures 3-6 Apical views of young male flower buds of Hedycarya arborea showing the apical merister flanked by tepal primordia which are numbered in the apparent order in which they were initiated.

$$
\begin{aligned}
& \text { S.B. }=\text { position of a subtending bract } \\
& B_{0}= \text { position of a bract above the } \\
& \text { A.M. } \text { aptending one } \\
& \text { apl meristem }
\end{aligned}
$$

Figures 7-8 Lateral views of young flower bud.s of Laurelia $\underline{\text { n.z. }}$. with the floral apex of each being flanked by two tepals. A.M. = apical meristem

Figure 2 Young flower bud of Laurelia $\underline{\text { n.z. }}$. in lateral abaxial (a) and adaxial (b) view. The tepal primordia are numbered in the apparent order in which they were initiated.

Figure 10 Median 1.s. of a young stamen primordium of Hedycarya arborea.

Figure 11 Median l.s. of male flower bud of Hedycarya arborea.

$$
A=\text { floral apex }
$$

Figure 12 L.s. part of a stamen of Hedycarya arborea with a row of archesporial cells (Ar) adjacent to the epidermis (Ep).

Figure 13 I.s. part of a stamen of Hedycarya arborea showing primary parietal ( $\mathrm{Aar}$ ) and primary sporogenous cells (Sp).

Figures 14,15\& 17

Stages in the development of stamens of Hedycarya arborea as seen in lateral view.

Figures 16, 18-21

Stages in the development of stamens of Laurelia $\underline{\text { n. }}$. A.M. = apical meristem

Further details in text. 
PLATE 27
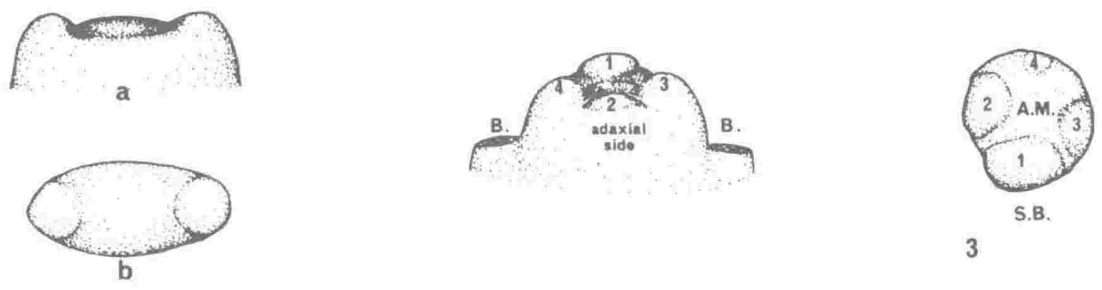

1

2

3

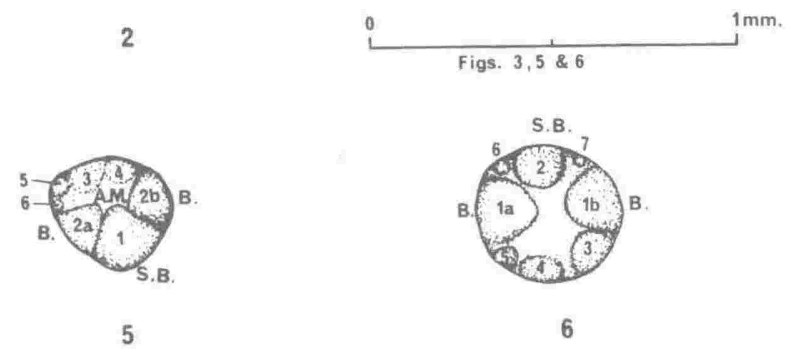

Hedycarya

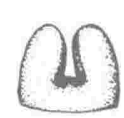

7
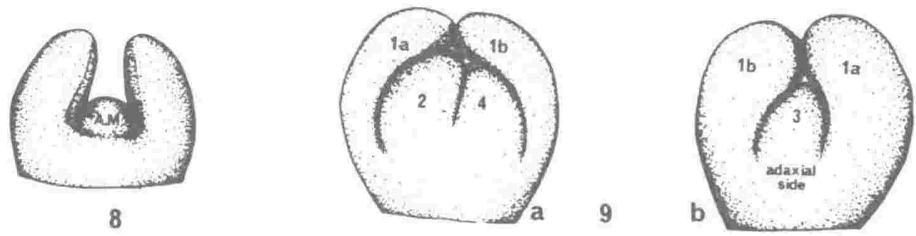

o $1 \mathrm{~mm}$
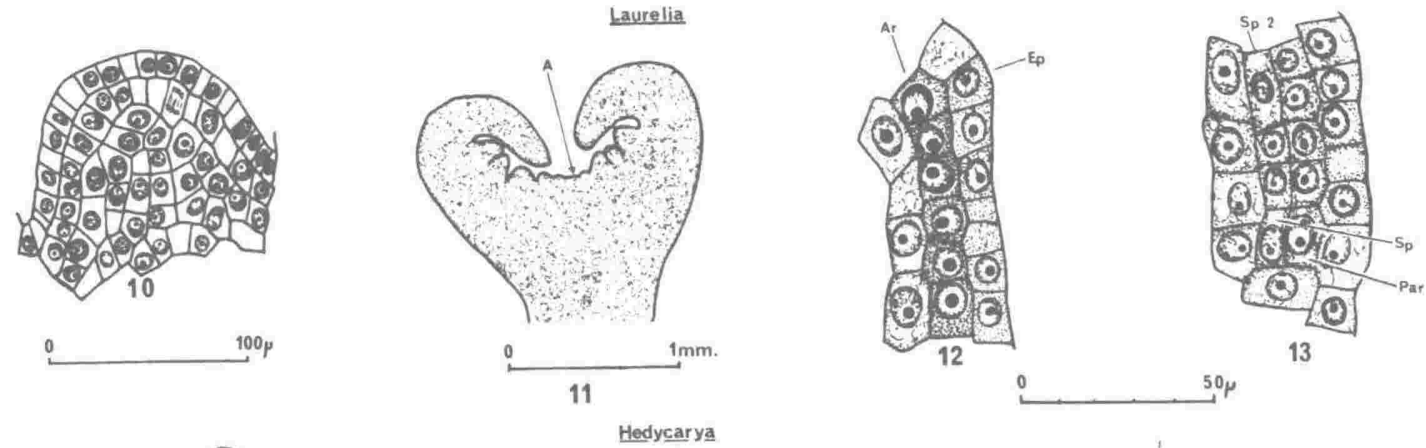

0

${ }_{100 \mu}$

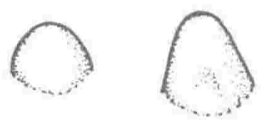

14

15
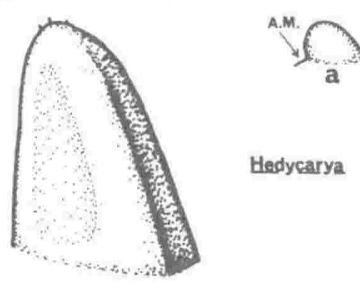

$Q_{b}$

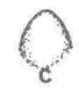

Hedycarya

16

17

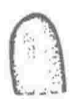

Laurelia

18

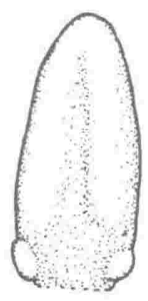

19

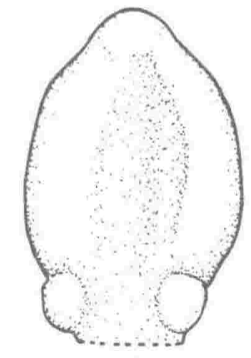

20
$50 \mu$

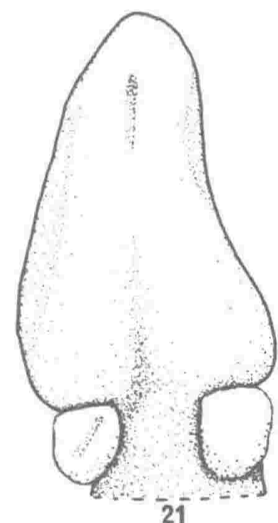




\section{PLATE 28}

Figure 1 L.s. of part of a male flower bud of Hedycarya arborea showing 3 stamen primordia in which sporogenous tissue is developing. $\times 140$

Figure 2 Median 1.s. of a stamen of Hedycarya arborea in which divisions are taking place in sporogenous and wall tissue. $x 140$

Figure 3 T.s. of stamens of Hedycarya arborea at a stage of development similar to that shown in figure 2. x 140 

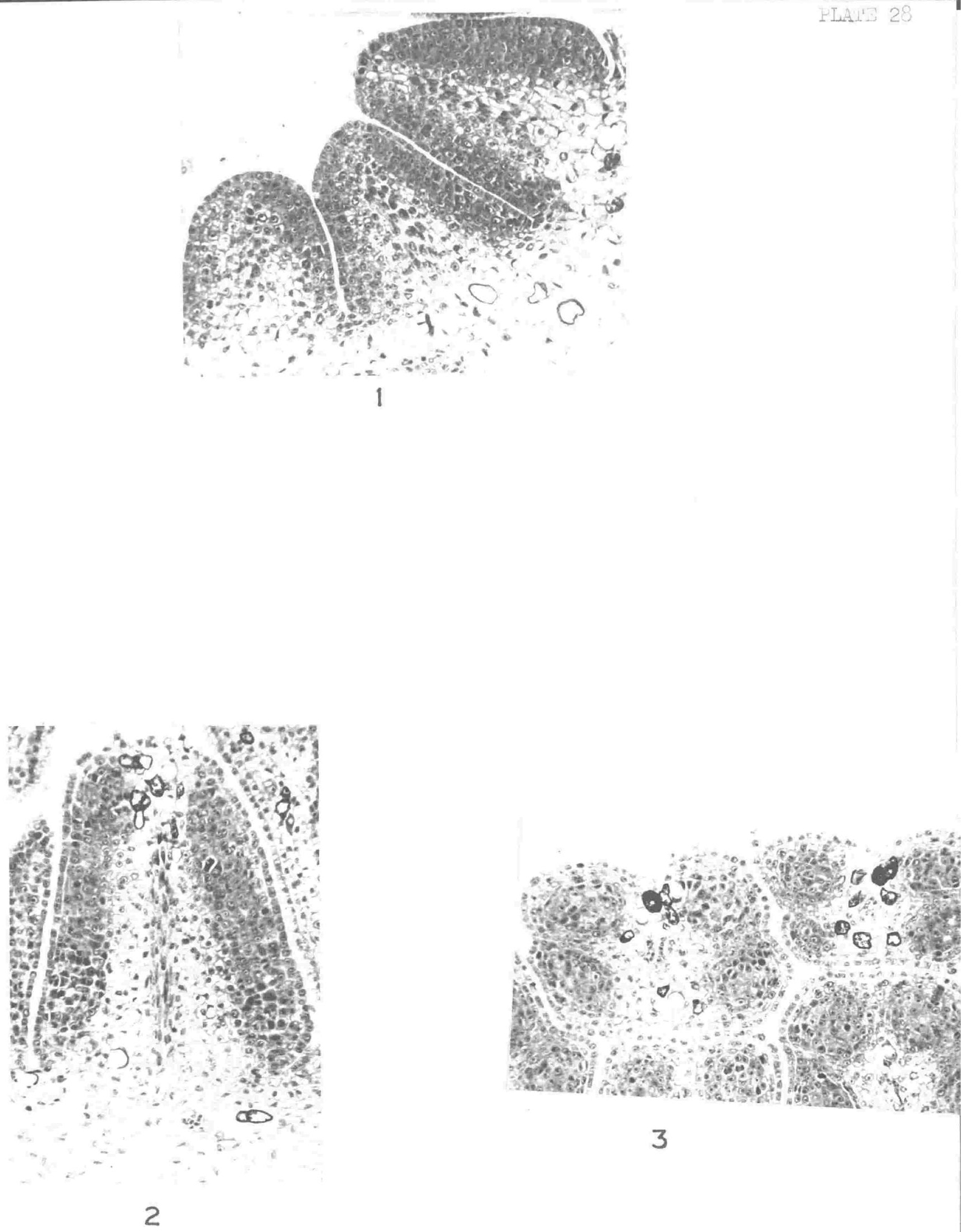


\section{PLATE 29}

Figure 1 L.s. of a stamen of Hedycarya arborea near the end of the development of sporogenous tissue. $x 130$

Figure 2 L.s. of part of a stamen of Laurelia $\underline{\text { n.z. }}$. showing an early stage in the development of staminal glands. $x 544$ 


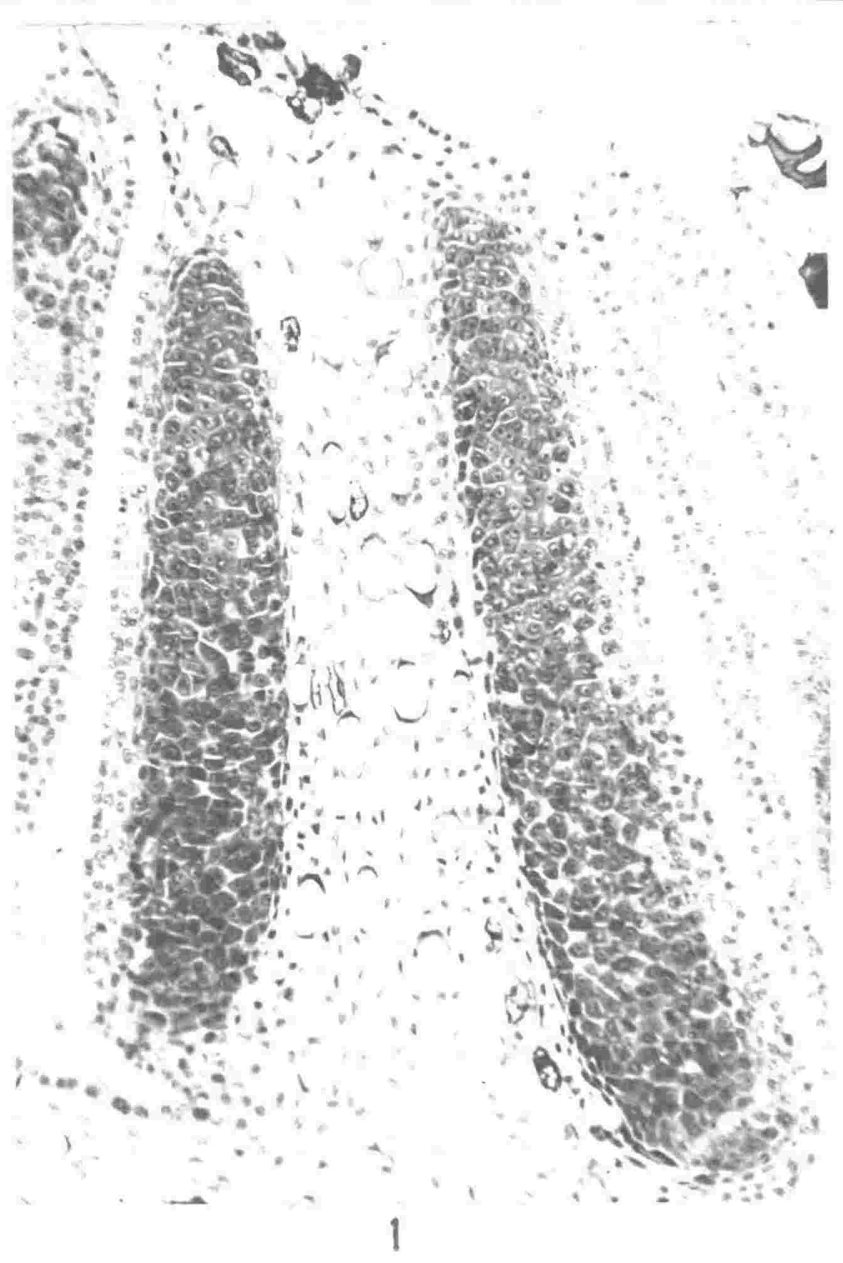




\section{PLATE 30}

Figure 1 L.s. of part of a stamen of Laurelia $\underline{n} \cdot \underline{z}$. showing an early stage in the development of a staminal gland at lower right.

Figure 2 L.s, of part of a stamen of Laurelia $\underline{n} \cdot \underline{z}$. showing an older staminal gland, in non-median section.

$$
s:=\text { periclinally dividing surface }
$$

Both figures x 544 


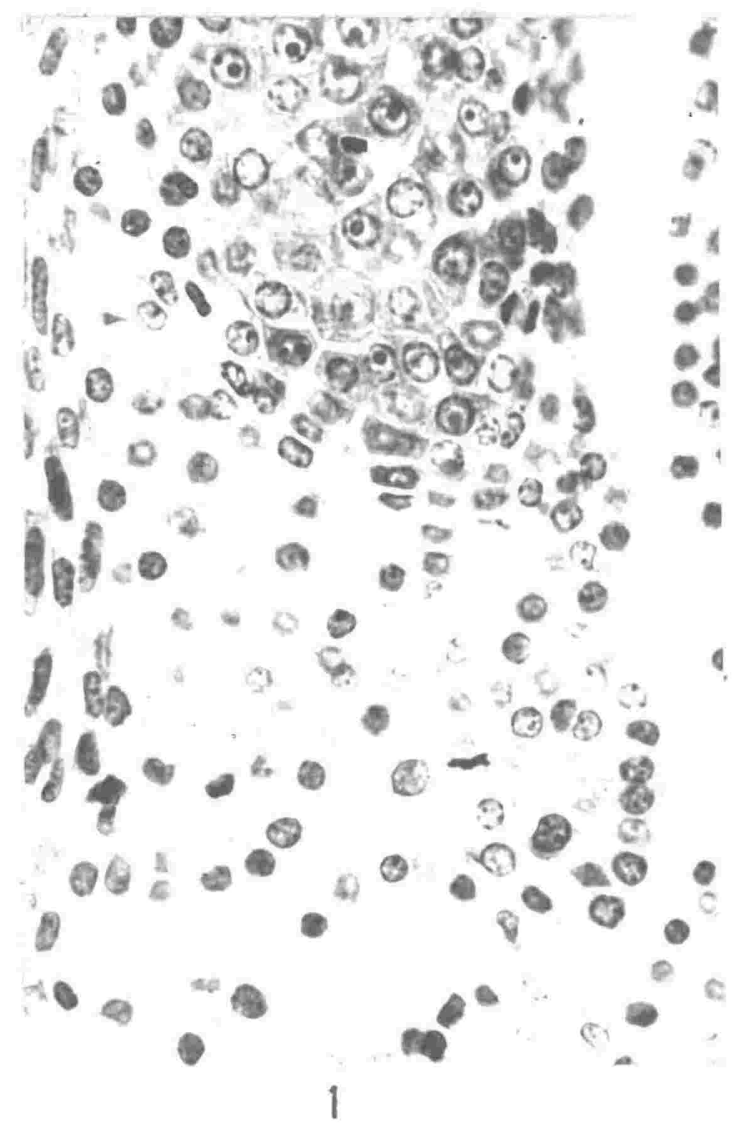

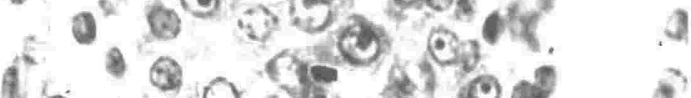

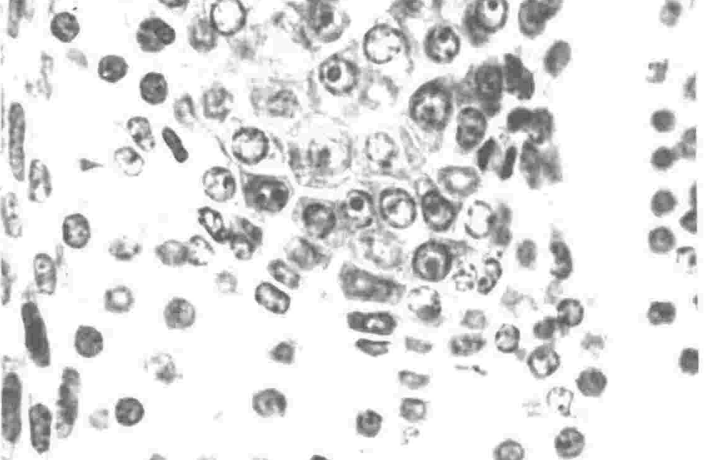

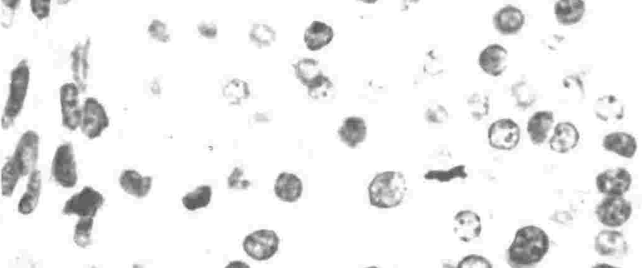

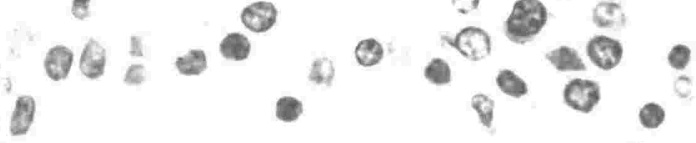

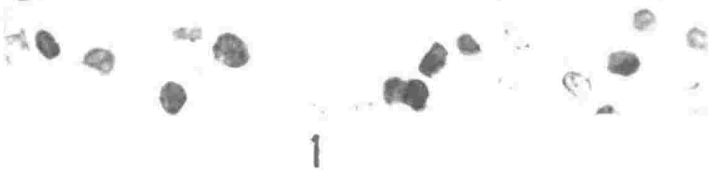

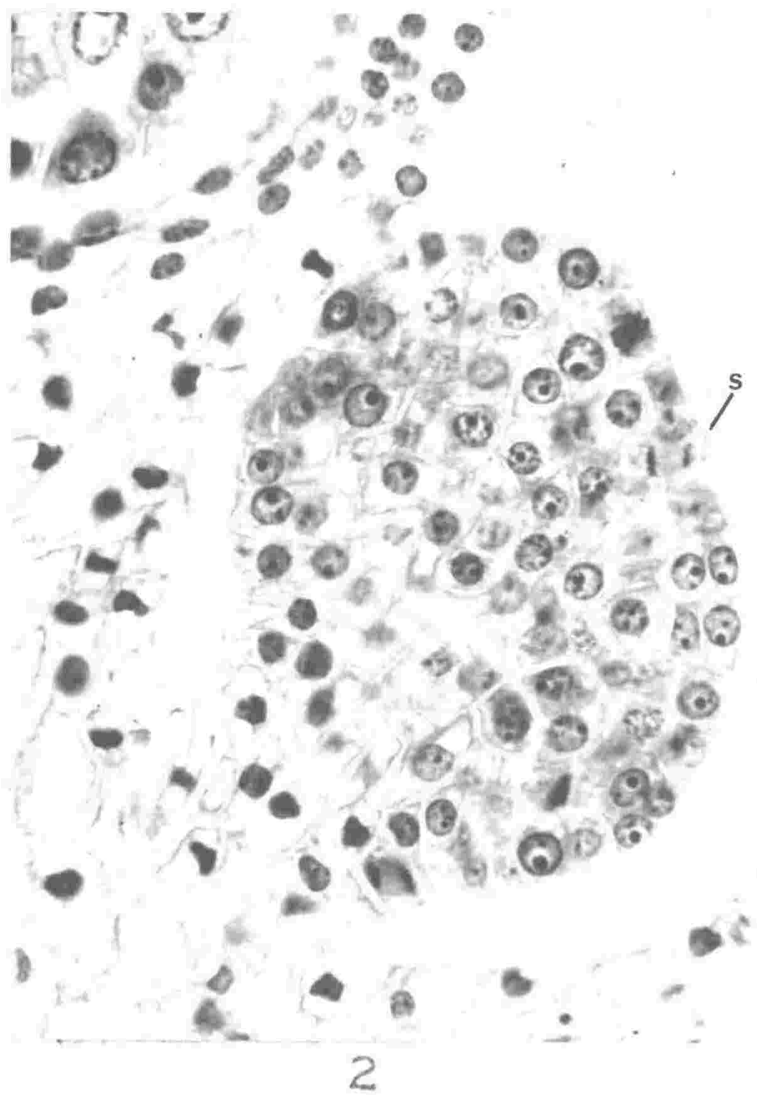


PLATE 31

Figure 1 T.s. of stamens of Laurelia n.z. through the staminal glands. $\quad x 140$

Figure 2 Median 1.s. of two nearly mature staminal glands of adjacent stamens of Laurelia n.

Figure 3 Adaxial lateral view of a mature stamen of Laurus nobilis. $\times 30$ 

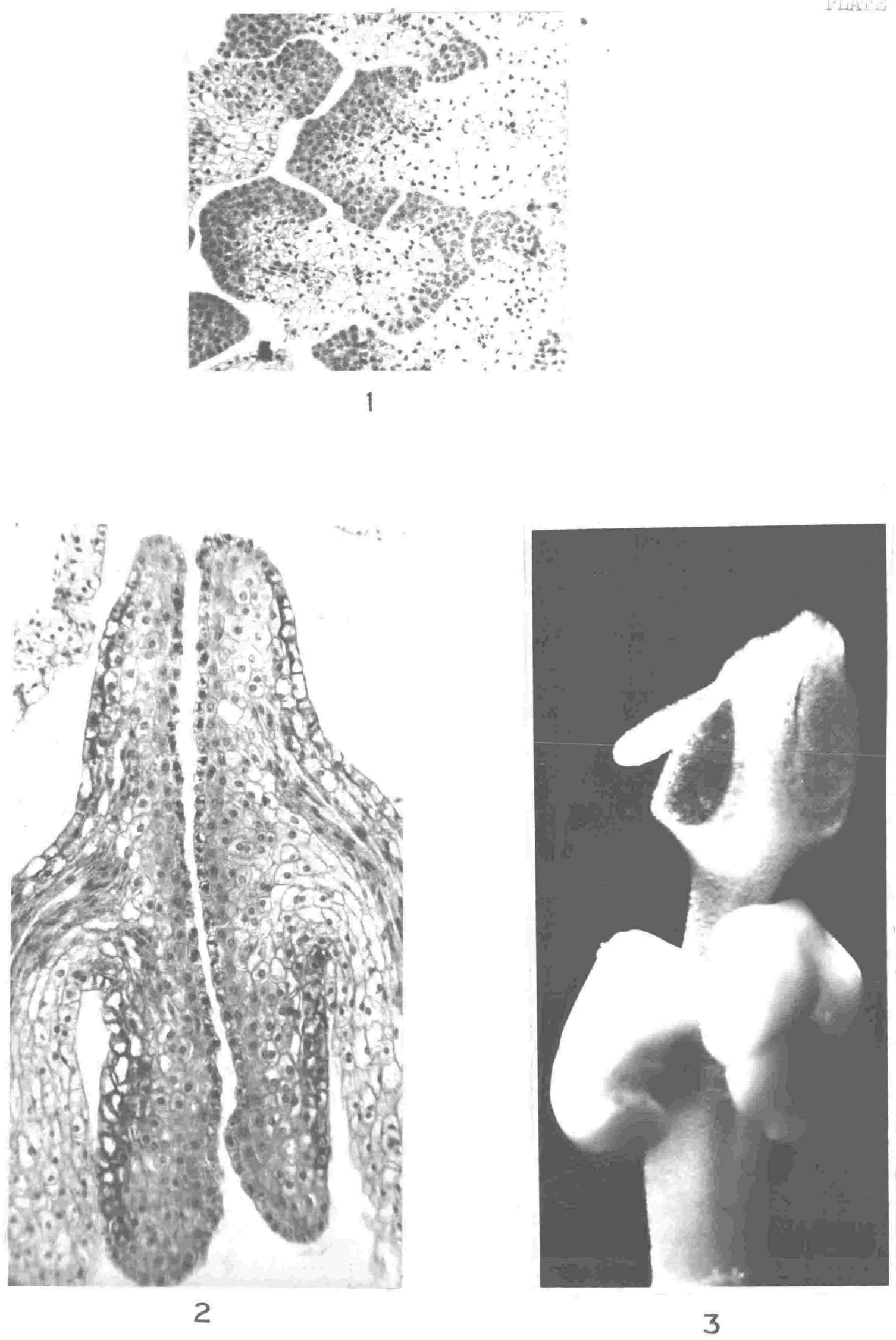


\section{PLATE 31}

Figure 1 T.s. of stamens of Laurelia $\underline{n} \cdot \underline{\underline{z}}$. through the staminal glands. $\times 140$

Figure 2 Median l.s, of two nearly mature staminal glands of adjacent stamens of Laurelia $\underline{n} \cdot \underline{z}$. x 130

Fioure 3 Adaxial lateral view of a mature stamen of Laurus nobilis. x 30 
PLATE 32

Figure 1 L. s. of a staminode ( at left) from a carpellate flower bud of Laurelia n.z. x 120

Figure 2 L.S. of a median part of a staminode from a somewhat younger carpellate flower bud of Laurelia $\underline{\underline{n}} \cdot \underline{\mathrm{z}}$.

$$
\begin{aligned}
e= & \text { epidermal cell on the adaxial } \\
& \text { surface which has been formed } \\
& \text { by a recent periclinal division } \\
& \text { of a surface cell }
\end{aligned}
$$




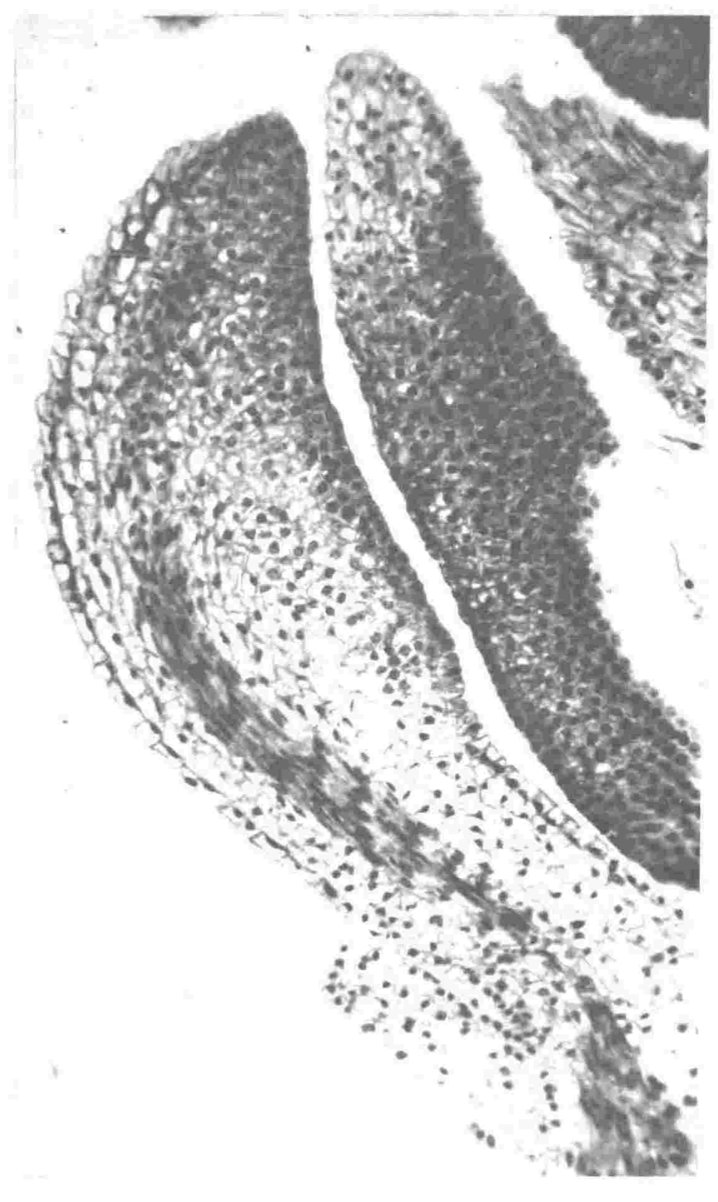

1

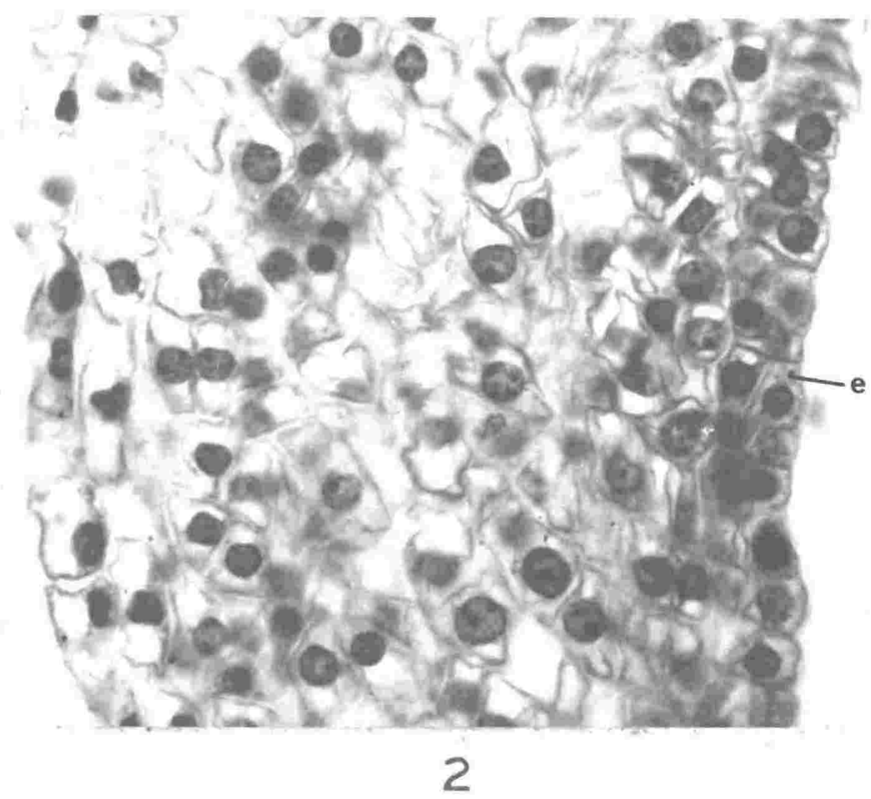


PLATE 33

Figure 1 L.s. of part of a pollen sac of Hedycarya arborea showing a tapetal cell at anaphase ( left of contre). A microspore mother cell (out of focus) is at centre right and is at prophase I. $\times 1400$

Figure 2

L.s. of part of a pollen sac of Hedycarya arborea with a tapetal cell at metaphase (lower right) and binucleate tapetal cells at left and centre. $\times 1400$

Figure 3

L.s. of part of a polien sac of Hed, carya arborea to show a tapetal cell with "sticky" chromosomes, at a stage when the pollen grains are becoming bicellular. x 1480 

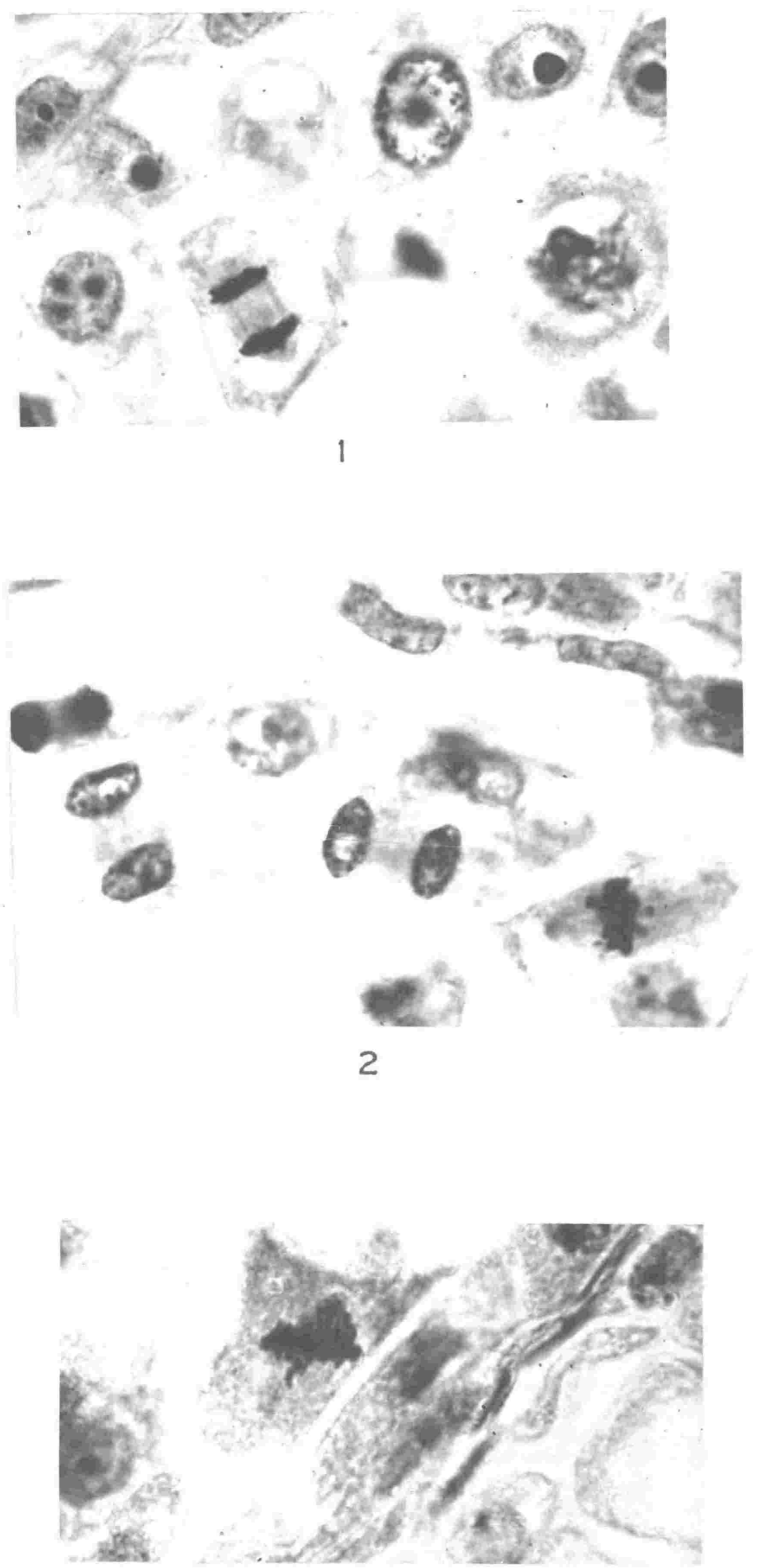


\section{PLATE 34}

Higure 1 T.s. of part of a pollen sac of Hedycarya arborea with microspore mother cells at the early synizesis stage of prophase I. Some of the microspore mother cells are sterile ( see text). $x 540$

Figure 2

T.s, of part of a pollen sac of Hedycarya arborea with microspore mother cells at telophase II. $\times 540$

Figure 3

Pollen mother cell of Hedycarya arborea (at right ) at metaphase-early anaphase I. × 2000 

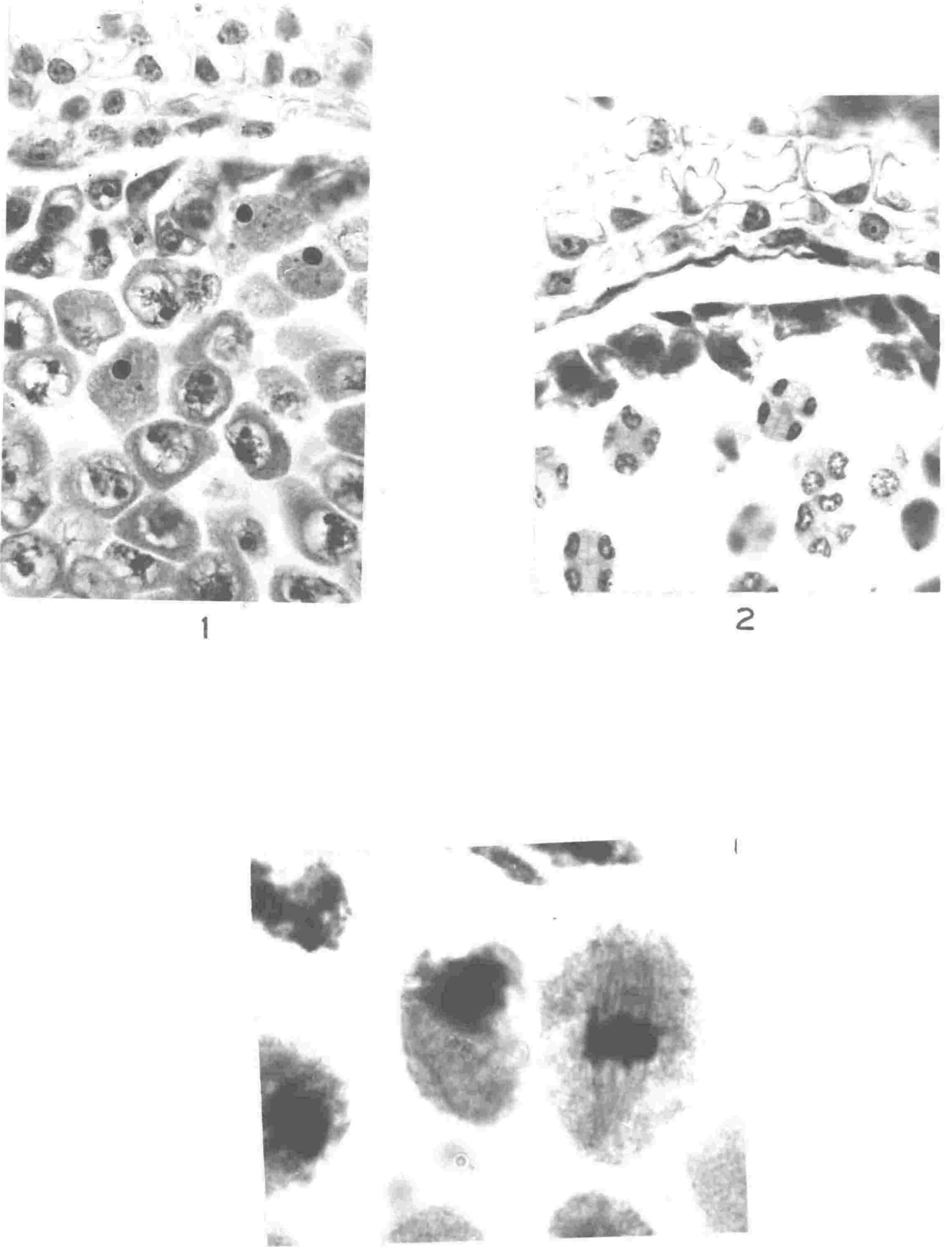


\section{PLATE 35}

Higure 1 Pollen mother cells of Hedycarya arborea undergoing microsporogenesis and with a sterile pollen mother cell at top centre. $\times 800$

Tigure 2 A sterile polien mother cell of Hedycarya arborea is shown, with nucleolar vacuoles, at right centre. × 560

Figure 3

A polien nother cell of Hedycarya arborea at telophase I ( left centre). Photo under phase contrast. $\times 1500$

Fisure 4

A pollen mother cell of Hedycarya arborea at telophase I. $\times 1050$ 

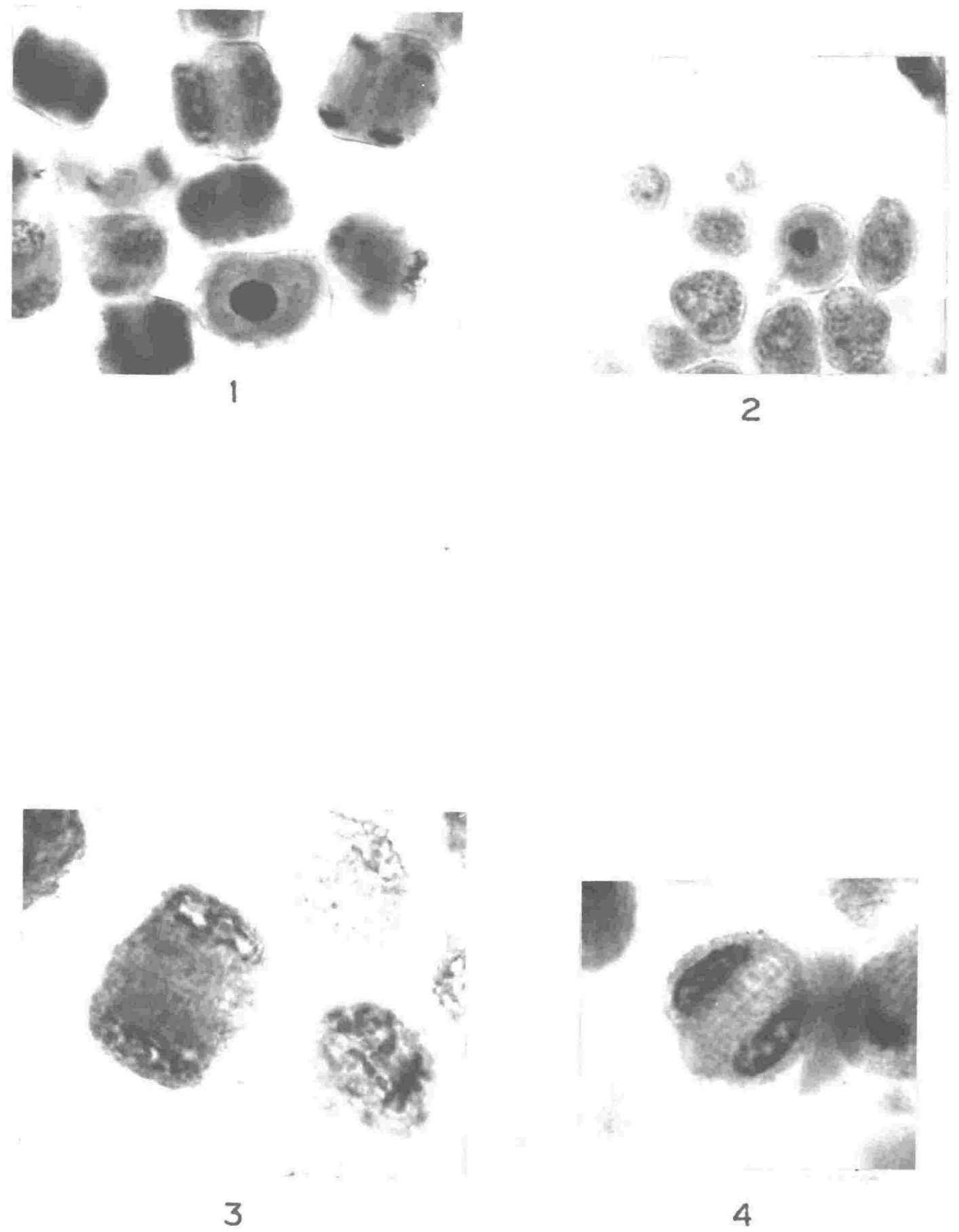


\section{PLATE 36}

Figures 1-3 show stages in microsporogenesis

in Hedycarya arborea.

Figure 1 Metaphase II $x 1350$

Figure 2 Metaphase II ( phase contrast)

x 1600

Figure 3 Telophase II ( phase contrast)

x 1600

Bigure 4 Tetrad of microspores of Hedycarya arborea x 1800 

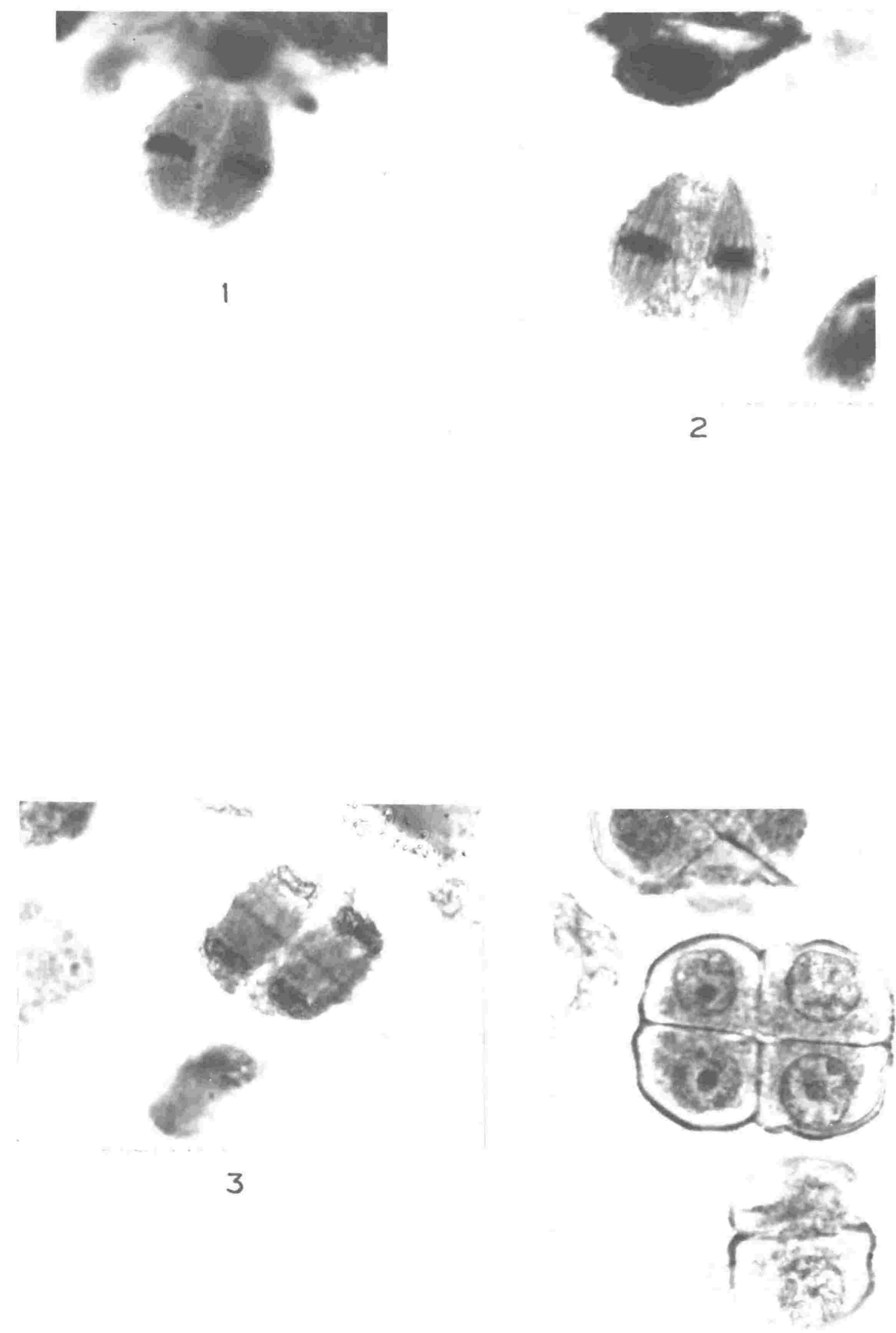


\section{PLATE 37}

Stages in the first division within the pollen grains of Hedycarya arborea.

Figure 1 Pollen tetrad at prophase. $\times 1600$

Figure 2 Pollen tetrad at metaphase - early anaphase.

x 1750

Figure 3 Tho microspores at anaphase.

× 1750

Figure 4 Pollen tetrad at the end of the division.

$\times 1750$ 


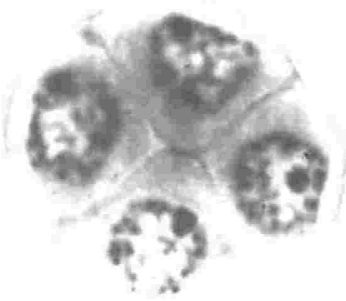

1

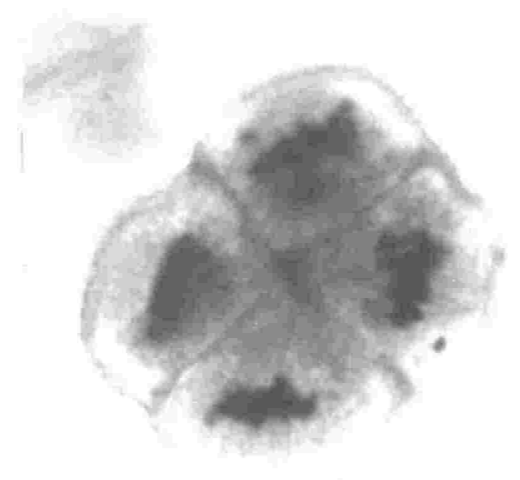

bi
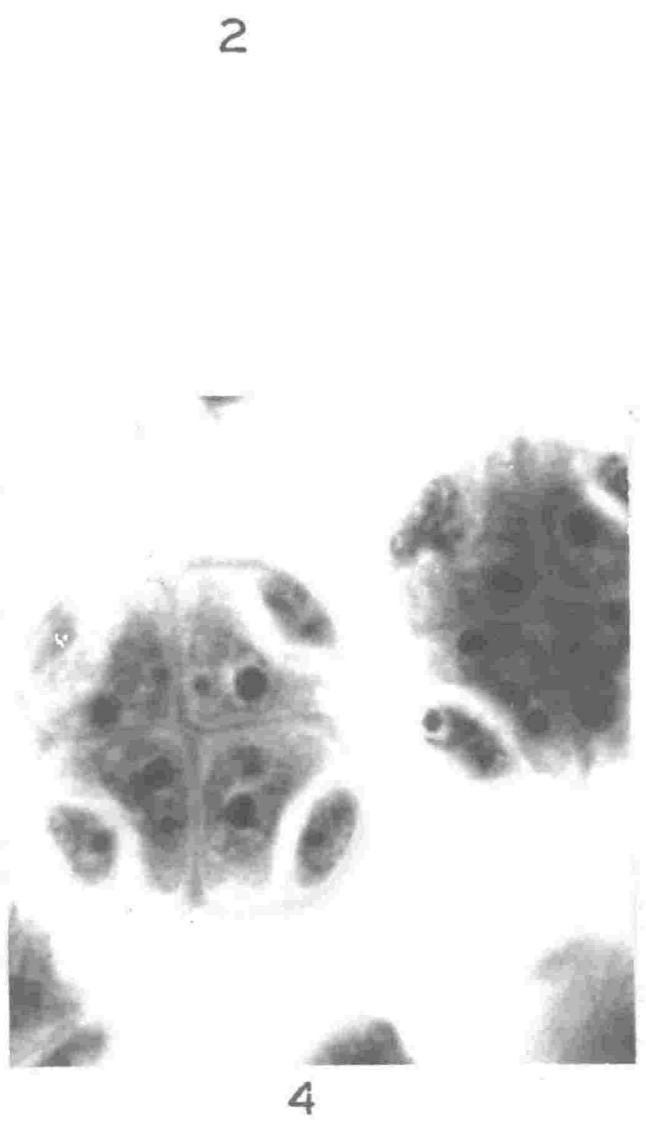
PLATE 38

Figure 1

Figure 2 Sections of two pollen tetrads of Hedycarya arborea showing ( upper centre) a microspore in which the cytoplasm of the vegetative cell is extending around the generative cell and at lower right there is a microspore in which the generative cell lies completely within the cytoplasm of the vegetative cell. Photo taken under phase contrast.

x 1800

Figure 3

Section of part of a pollen sac of Hedycarya arborea showing wall layers and maturing pollen tetrads. $\times 550$ 

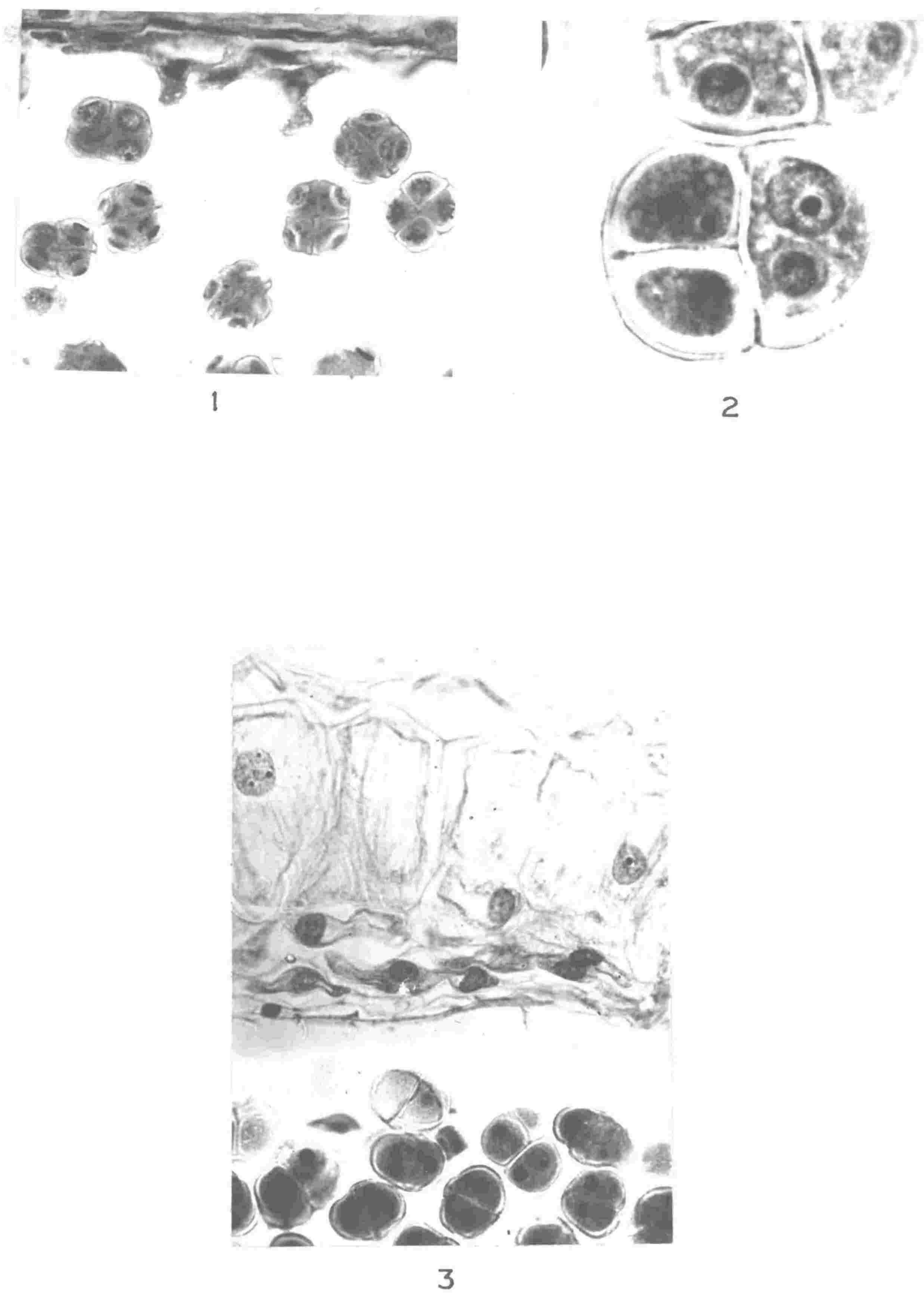
PLATE 39

Figure 1 T. s. stamen of Laurelia n. z.with polien mother cells at prophase I. $\times 132$

Figure 2 T.S. stamen of Hedycarya arborea with pollen mother cells at prophase I.

$$
\times 132
$$

Figure 3 T.s. of part of a pollen sac of Laurelia n.... with polien mother cells at leptotene of prophase I. Some tapetal nuclei are dividing.

$$
\times 480
$$

Figure 4 T.s. stamen of Laurelia n-z. at a time when the first division is taking place within the pollen grains. $\times 108$ 

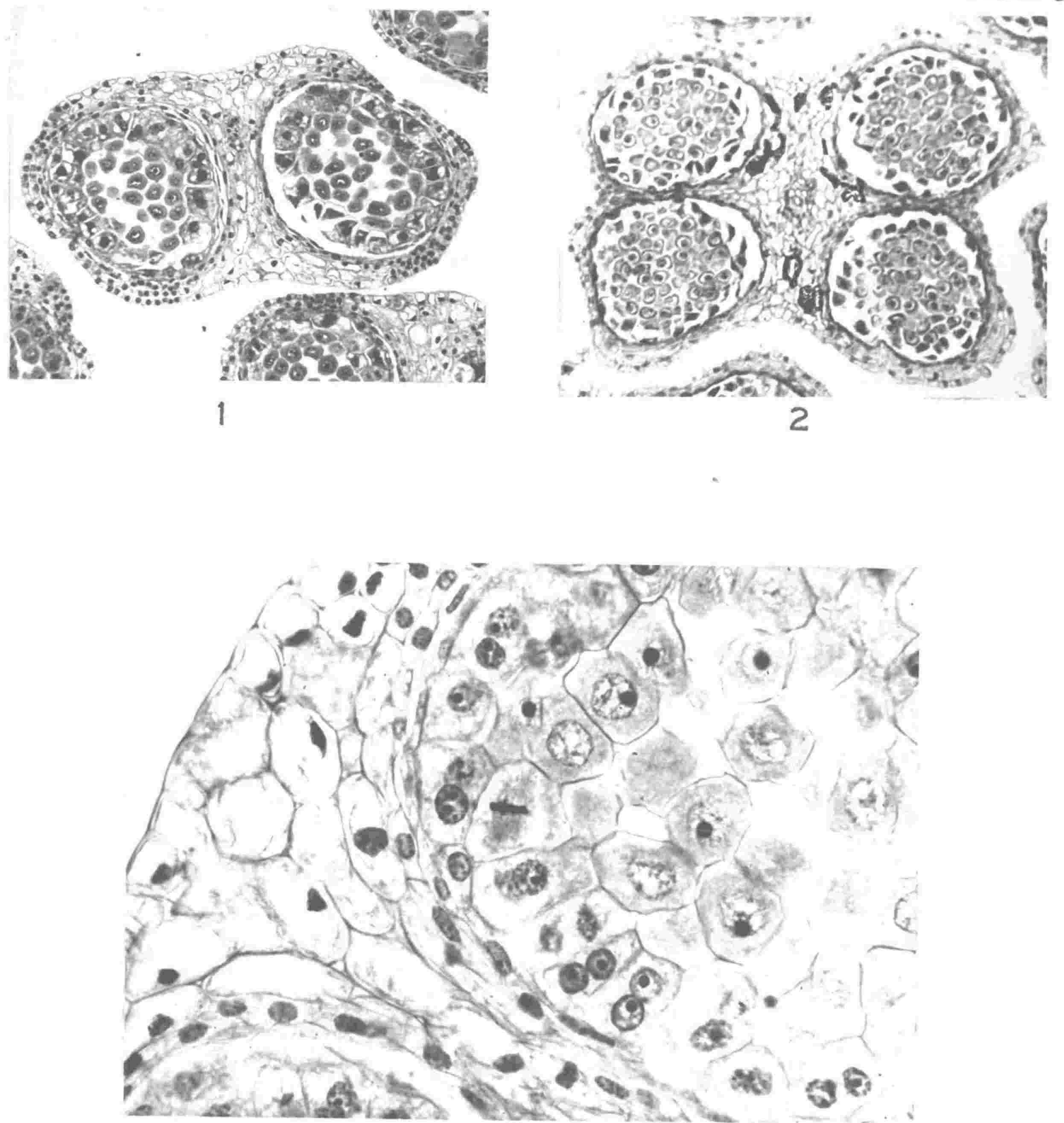

3

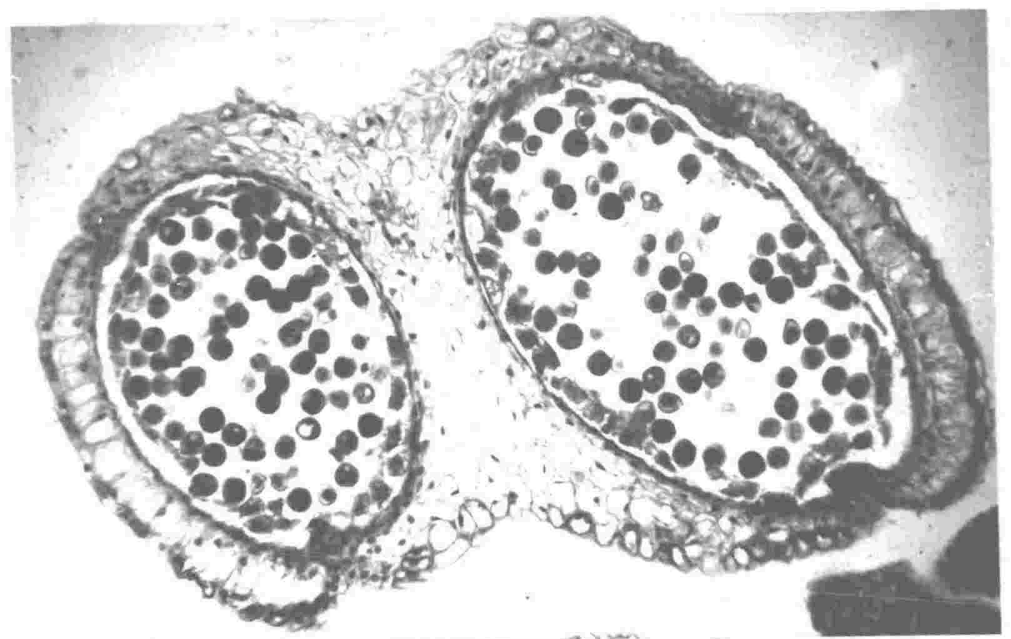




\section{PLATE 40}

Figure 1 T.s. of part of a stamen of Laurelia n.z. with pollen mother cells at metaphase-early anaphase $I$.

$$
\times 550
$$

Figure 2 T.s. of part of a stamen of Laurelia $\underline{\text { n.z. }}$. with pollen mother cells at telophase $I$.

x 660

Figure 3 T.s. of part of a stamen of Laurelia n. $\underline{\text { z. With }}$ pollen mother cells at anaphase II.

x 660 
PLATE 41

Figure 1 L.s. of part of a pollen sac of Laurelia $\underline{n} \cdot \underline{\text { z. }}$ with unicellular pollen grains.

$$
\times 660
$$

Figure 2 L.S. of part of a nearly mature stamen of Laurelia $\underline{n} \cdot \underline{z}$. in which the pollen sac at left contains only sterile pollen. $\times 70$ 


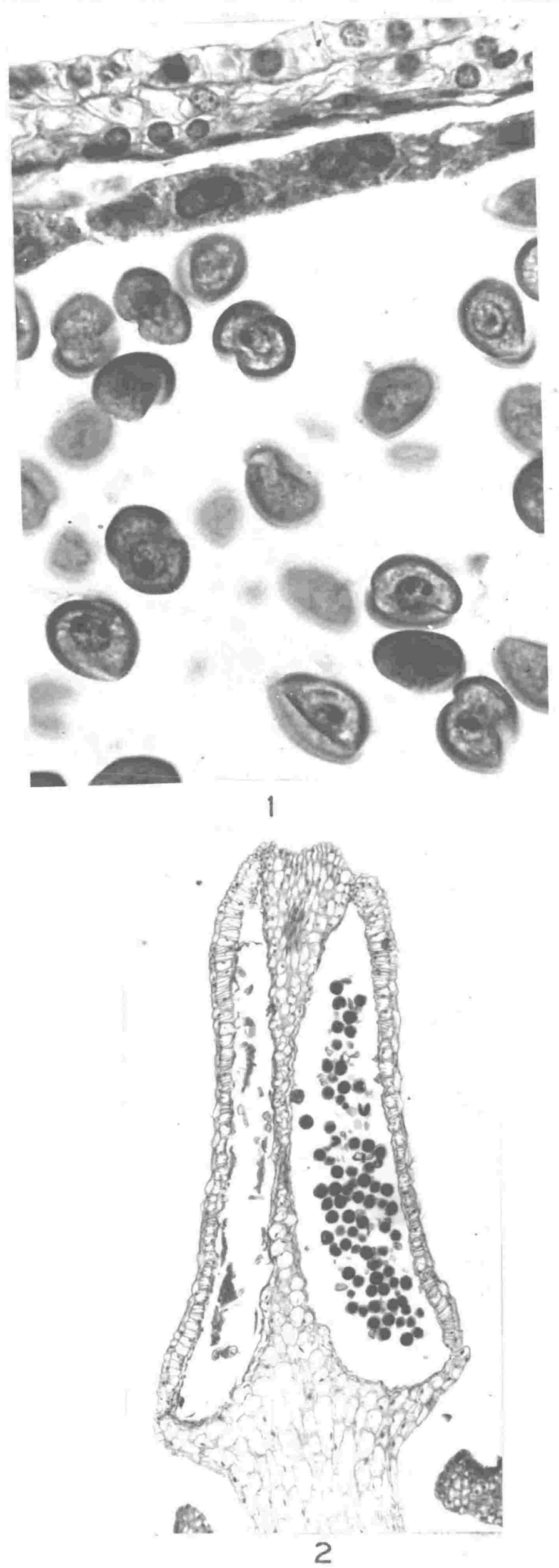




\section{PLATE 42}

Sections illustrating stages in microsporogenesis in Laurelia $\underline{\text { n. }}$.

Figure 1 Pollen mother cell at early anaphase I ( lower centre) under phase contrast. The upper part of the photo shows tapetal cells and flattened cells of wall layers.

Figure 2 Pollen mother cell ( centre) at telophase I.

Figure 3 Pollen mother cell at early anaphase II ( centre).

Figure 4 The same as figure 3 but under phase contrast.

A71 figs. $\times 1500$ 


\section{PLAIPE 43}

Sections illustrating stages in microsporogenesis in Laurelia $\underline{\text { n. }} . \underline{.}$.

Figure 1 Pollen mother cell at anaphase II.

Figure 2 The same as figure 1 but under phase contrast.

Figure 3 Pollen mother cell at telophase II.

Figure 4 The same as figure 3 but under phase contrast.

All figs. $x 1500$ 
PLAT 43
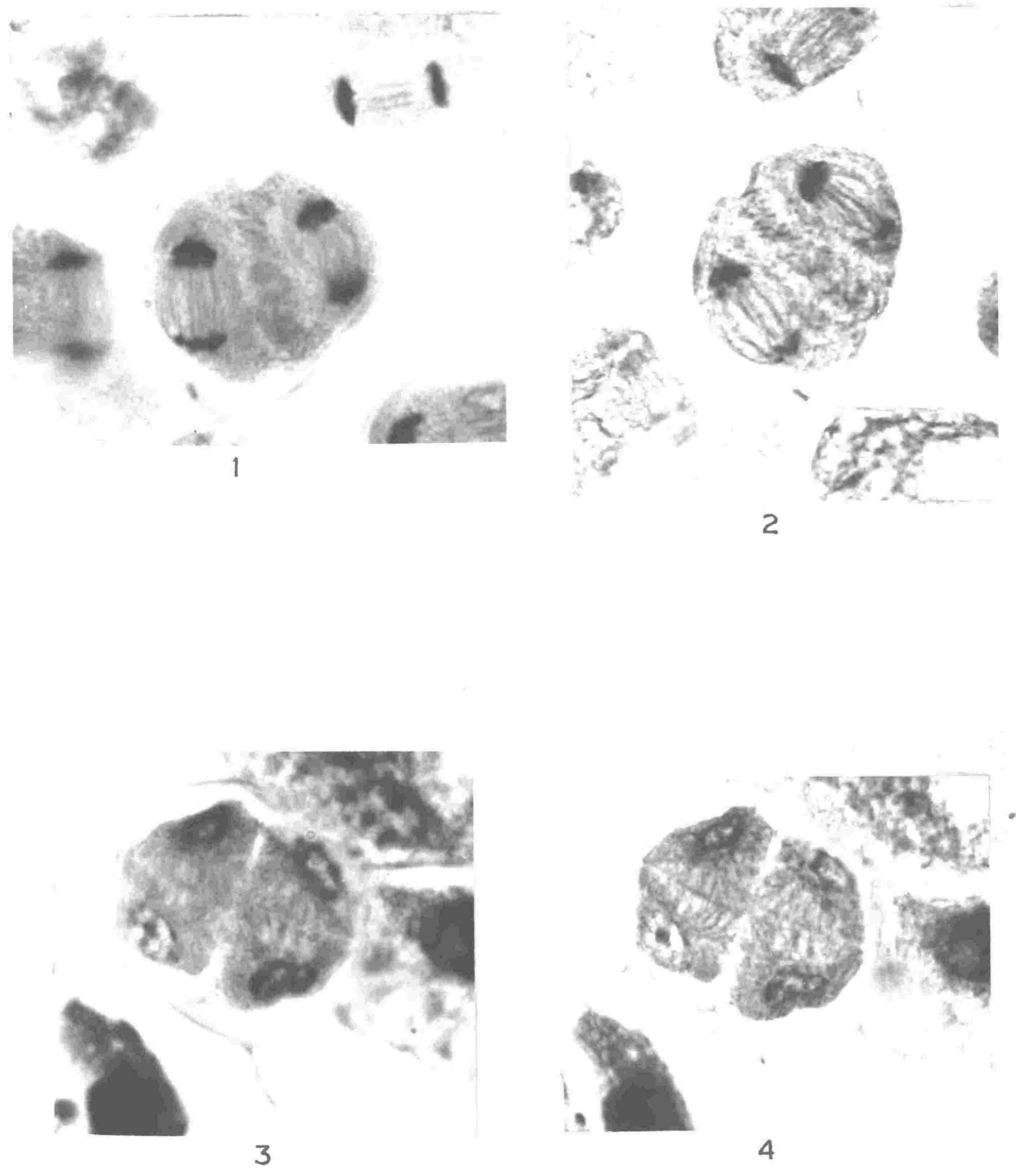


\section{PLATE 44}

Figure 1 Pollen mother cell of Laurelia n..… at late telophase II.

x 1500

Figure 2 The sane as figure 1 but under phase contrast. x 1500

Figure 3 Tetrad of young polien grains of Laurelia $\underline{n} \cdot \underline{\text { z. }}$.
\[ 1500 \]

Figure 4 T.s. of a pollen sac of Leurelia $\underline{n} \cdot \underline{z}$. to show an aborted tapetal layer ( stained black) enclosing pollen mother cells at early prophase $I$. $\times 580$ 


\section{soy}
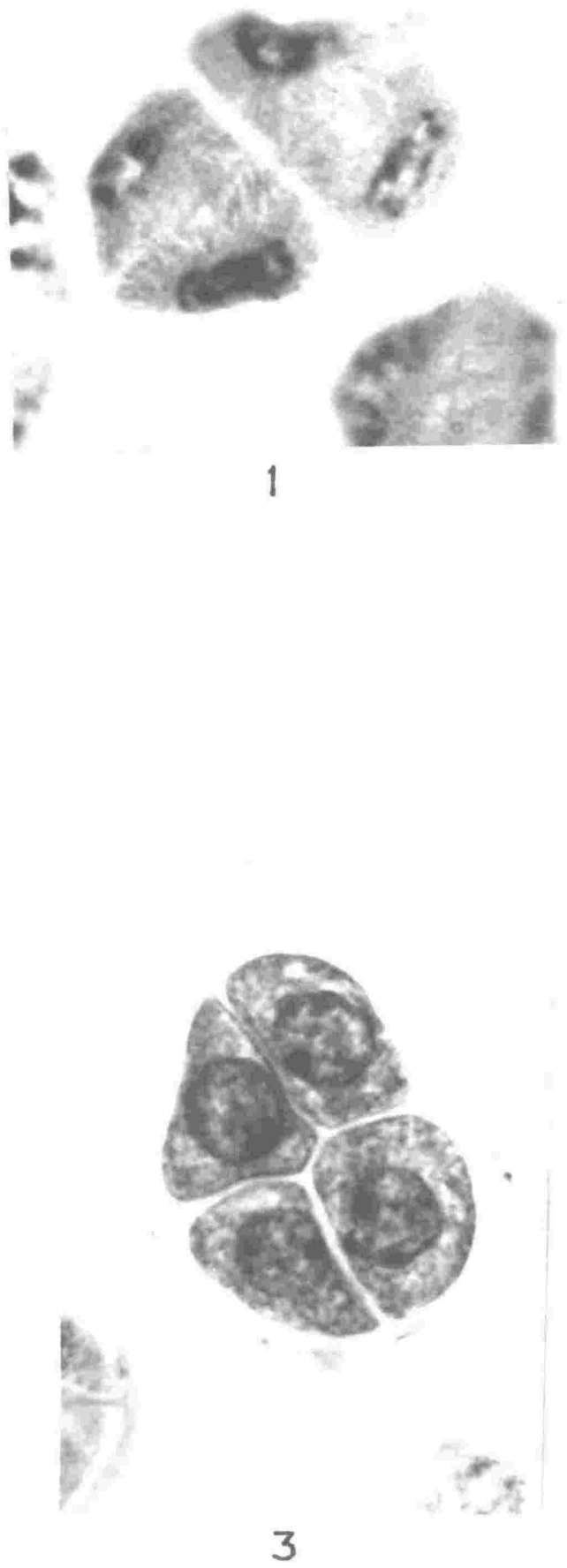
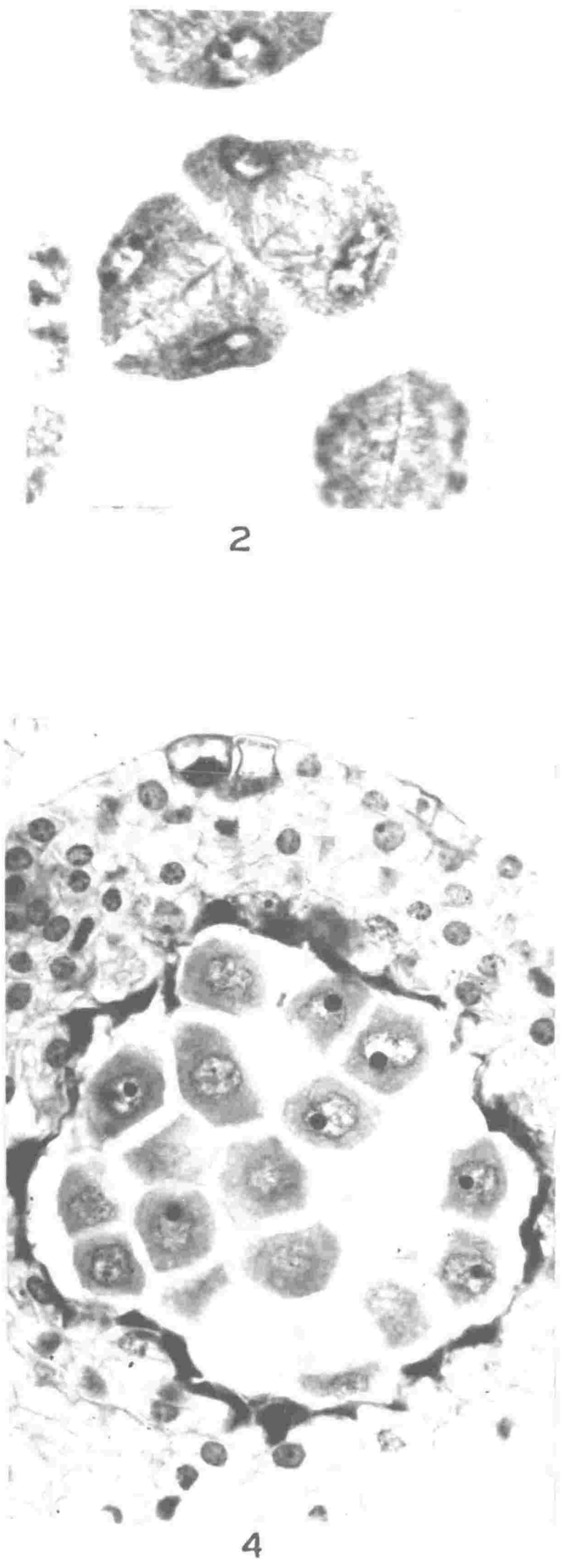
PLATE 45

Figure 1 Uninucleate pollen grain of Leurelia $\underline{n} \cdot \underline{z}$. ( phase contrast ).

Figure 2 Uninucleate pollen grain of Laurelia $\underline{n} \cdot \underline{z}$. (phase contrast) with large vacuoles in the cytoplasm.

Figure 3 Uninucleate pollen grain of Laurelia $\underline{n} \cdot \underline{z} \cdot$ (phase contrast) in which the nucleus is appressed against the wall of the grain. Photo taken under phase contrast.

Figure 4 Pollen grain of Laurelia $\underline{n-z}$. with its nucleus at prophase as seen under phase contrast.

Figure 5 Pollen grain of Laurelia n... at metaphase of the first division (phase contrast).

All figs, $x 1370$ 

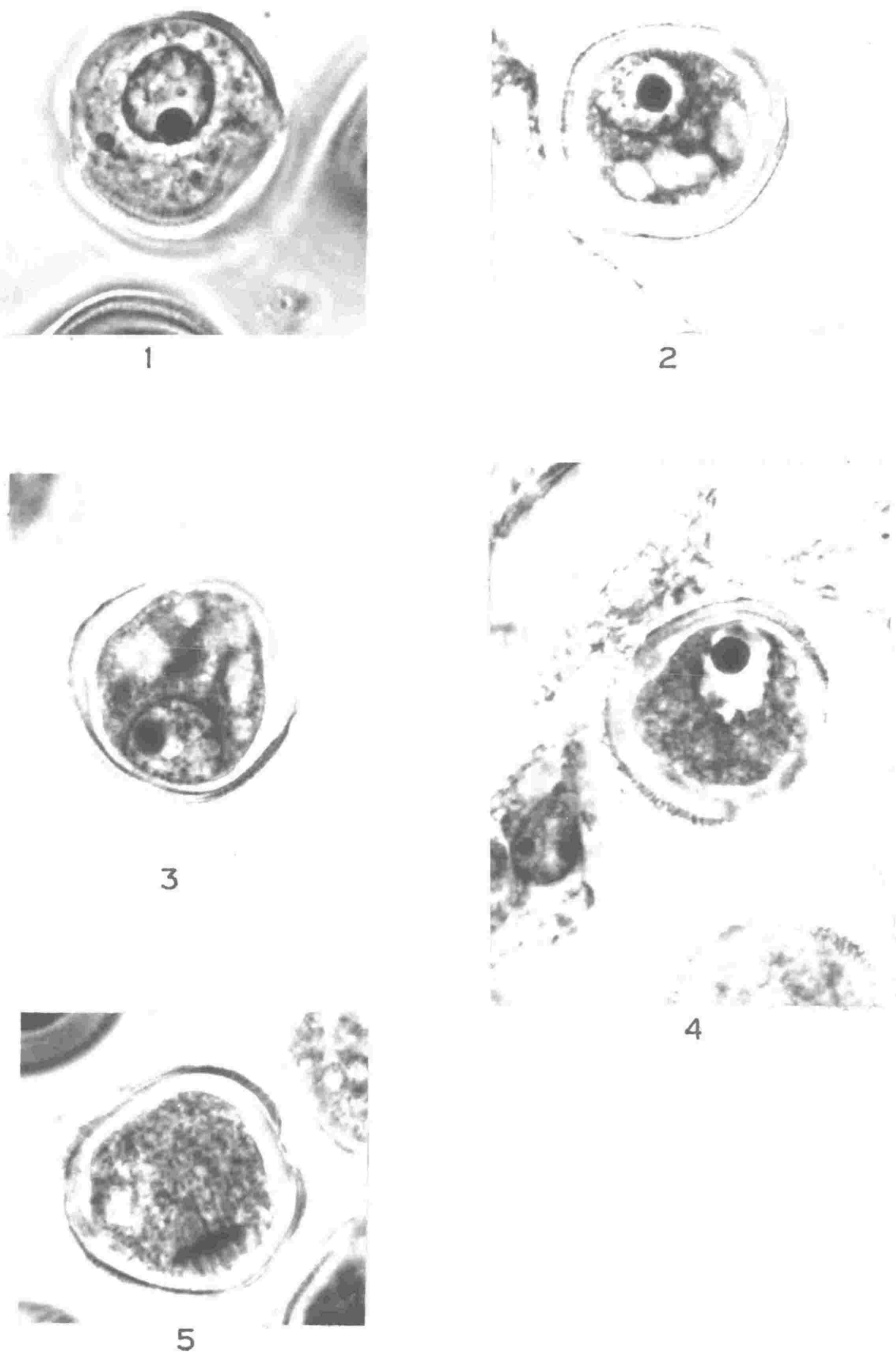
PLATE 46

Figure 1 Pollen grain of Laurelia n.z. at anaphase (phase contrast )

Figure 2 Young two celled pollen grain of Laurelia $\underline{\text { L. }}$. as seen under phase contrast.

Figure 3 Young two celled pollen grain of Laurelia $\underline{n} \cdot \underline{z}$. showing vacuoles in the cytoplasm of the vegetative cell.

Figure 4 The same as figure 3 but under phase contrast. All figs. $x 1370$ 

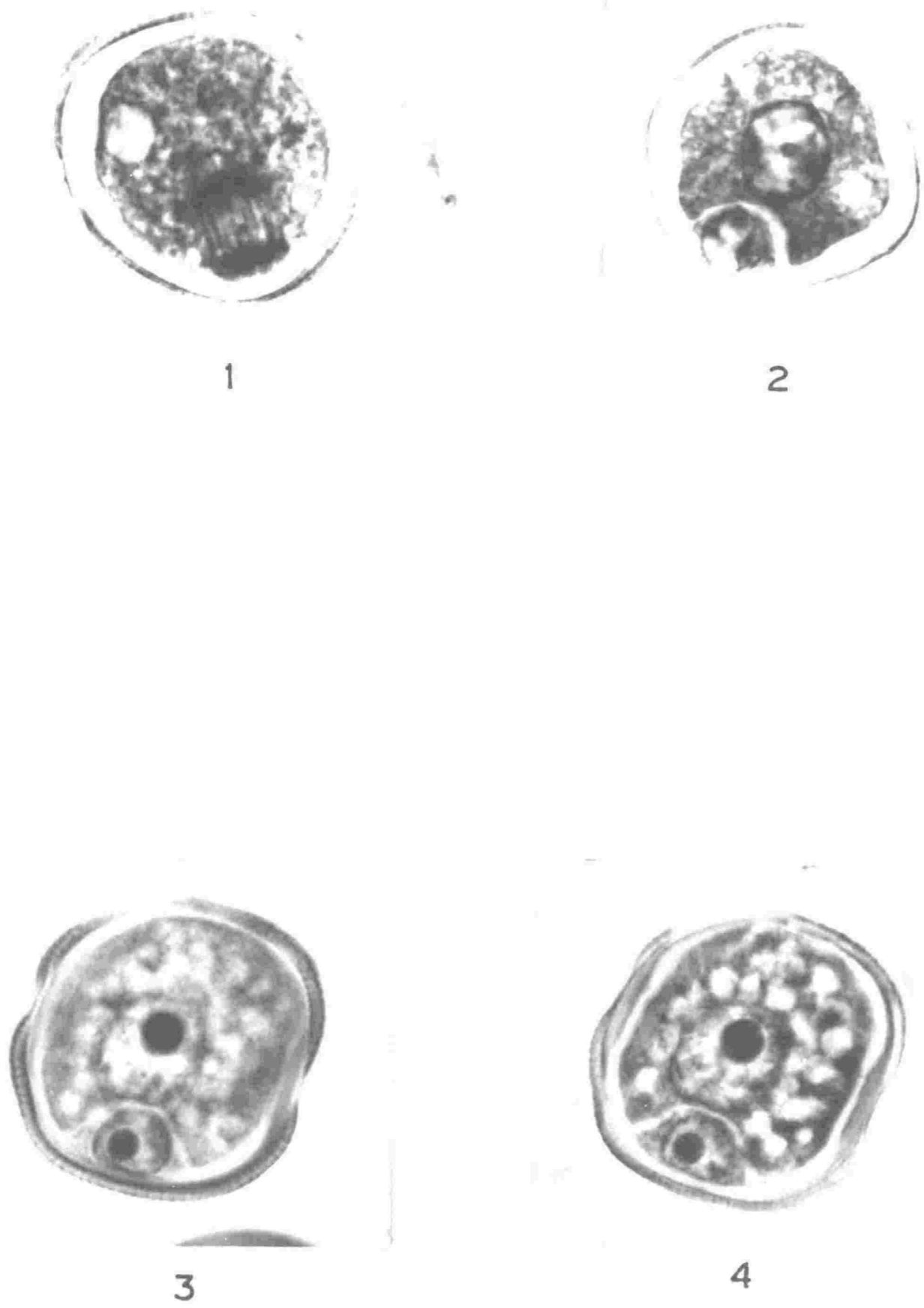
PLATE 47

Figure 1 Mature two celled polien grain of Laurelia $\underline{\underline{n}} . \underline{\mathrm{z}}$. × 1370

Figure 2 The same as figure 1 but under phase contrast.

Figure 3 Median 1.s. of part of the upper portion of a carpel of Hedycarya arborea. Further details in text. x 130

Figure 4 Innature ( left) and mature carpels of Hedycarya arborea as seen in lateral ad-abaxial view.

$\times 28$ 


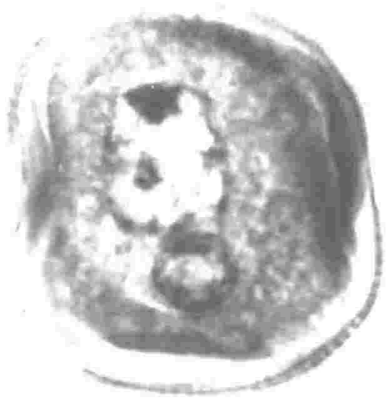

1

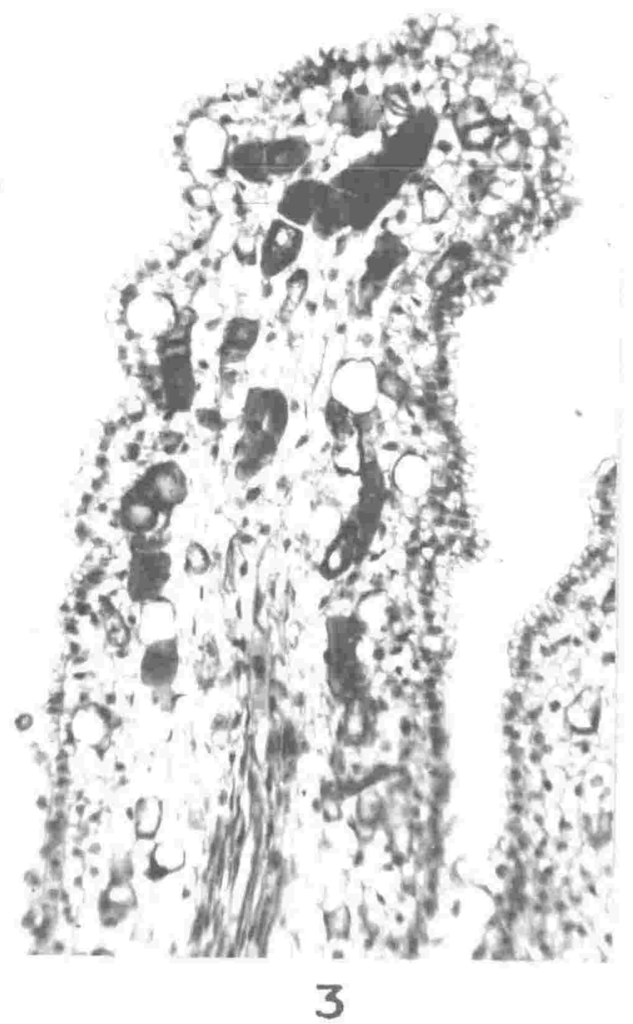

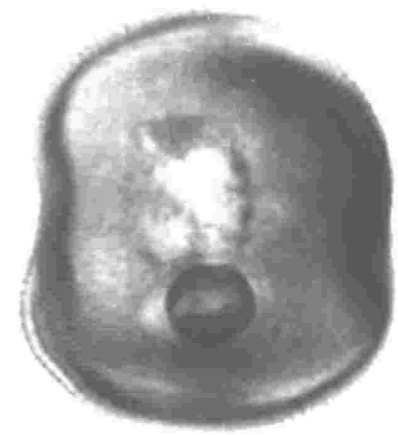

2

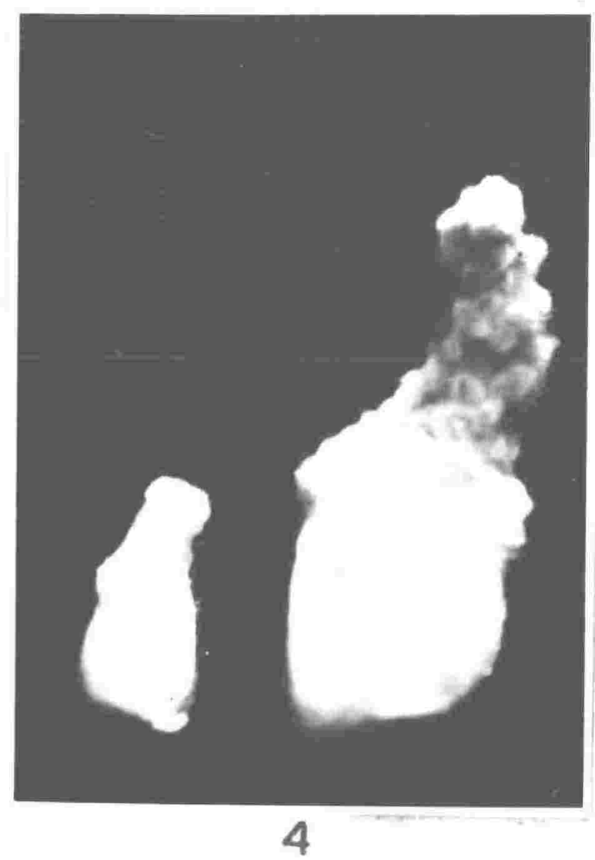


Figure 1 Section of a pollen grain of Laurelia $\underline{\text { n.z. }}$ showing the generative cell dividing (telophase). The nucleus of the vegetative cell lies in a different plane of focus and is not shown.

Figure 2 Section of a three celled pollen grain of Laurelia $\underline{n} \cdot \underline{z}$. The two male cells are situated above the nucleus of the vegetative cell.

Figures 3-7 Stages in the ontogenetic developnent of carpels of Hedycarya arborea as seen in lateral view. The opening of each carpel faces the centre of the flower. $\mathrm{ov}=$ ovule

Figure 8 Mature carpel of Hedycarya arborea. The cleft of the carpel lies between $x-y$. 


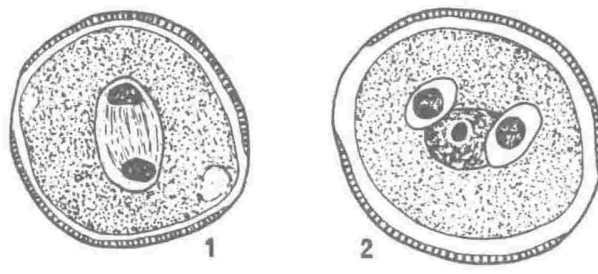

$30 \%$
(1)

3

PLATE 48
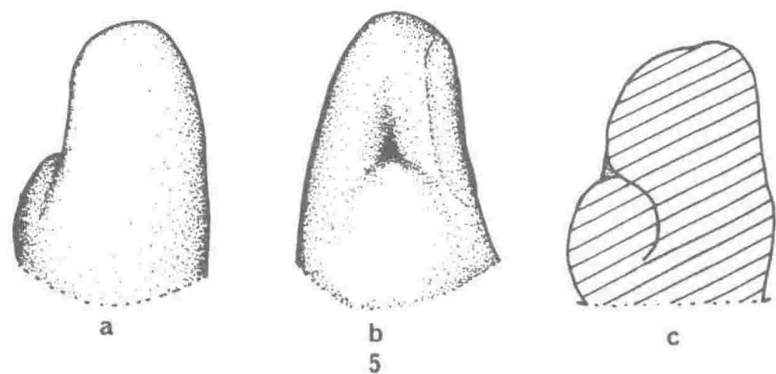

c

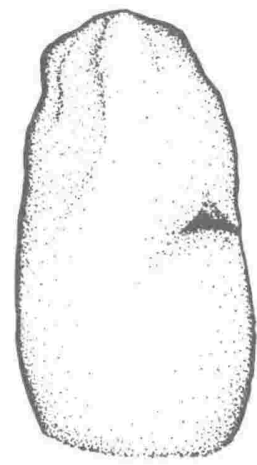

a

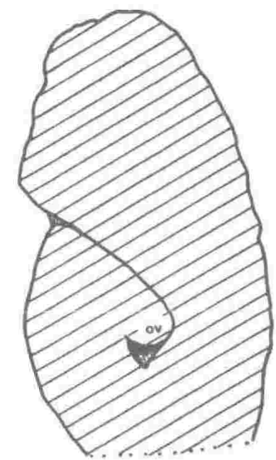

6

b
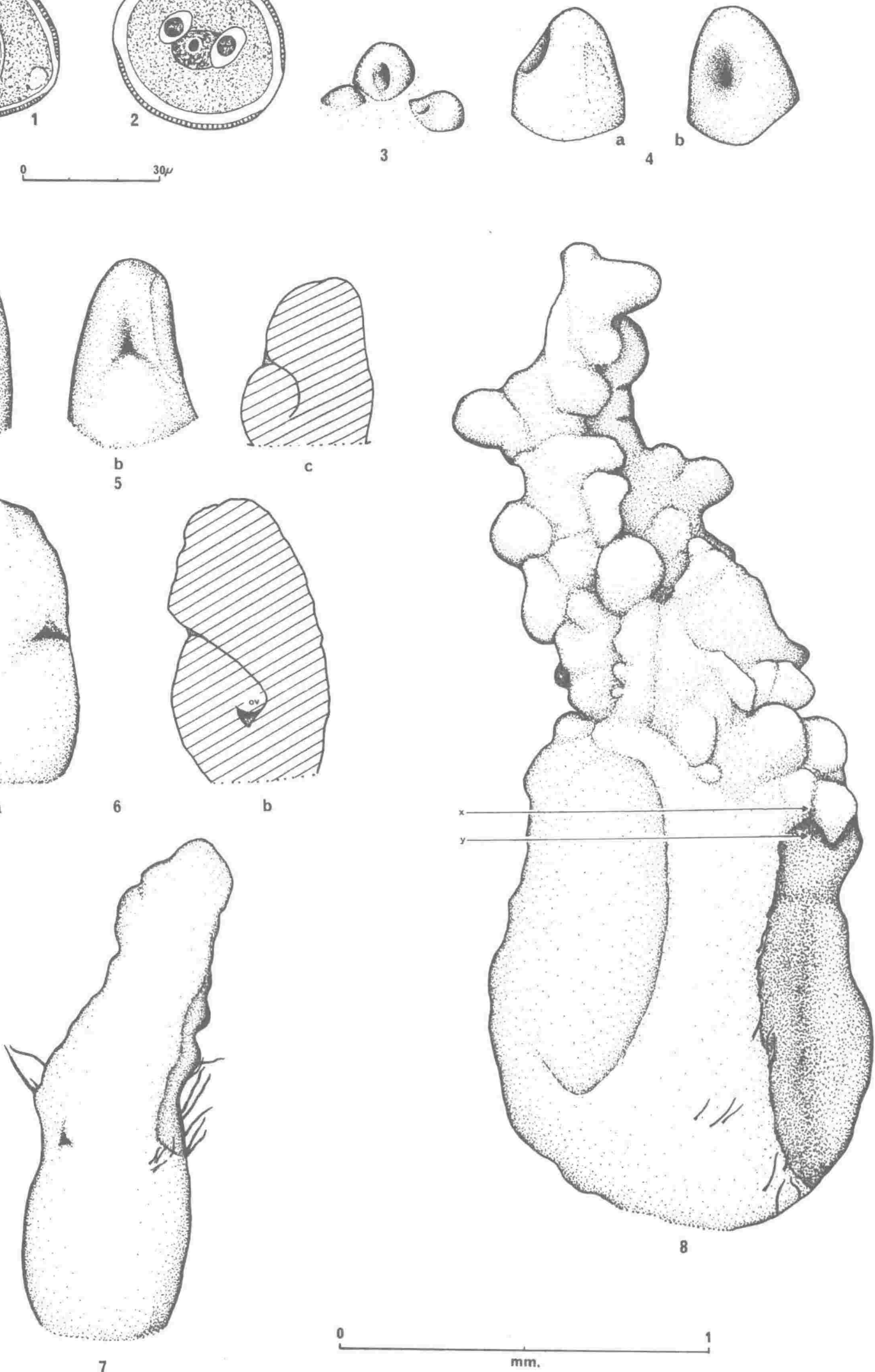

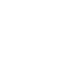


PLATE 49

Figures $1-5$

Stages in the ontogenetic development of carpels of Laurelia $\underline{\text { n.z. }}$. as seen in lateral view. The opening of each carpel faces the centre of the flower.

$$
\text { ov }=\text { ovule }
$$

Figures 6-7 Mature carpels of Laurelia n.z. in lateral ad-abaxial view ( figure 6 ) and lateral introrse view ( figure 7 ). The dotted line in each carpel indicates the position of the ovile.

$$
\mathrm{cz}=\text { cross zone }
$$




$$
\mathbb{R} \| \mathbb{H}
$$


PLATE 50

Figures 1-5

Progressive transverse sections of a carpel of Hedycarya arborea in which the ovule is at the megaspore mother cell stage. Sections begin near the distal tip ( stigma) of the carpel ( figure 1) and are concluded in PLATE 51.

Ali figs. $\times 132$ 


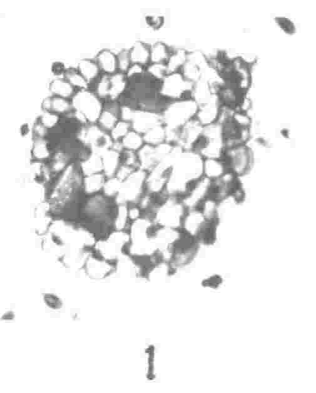

20

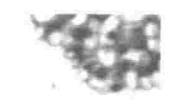

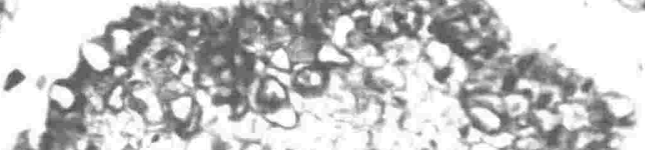

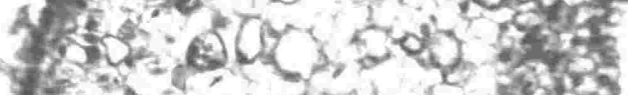

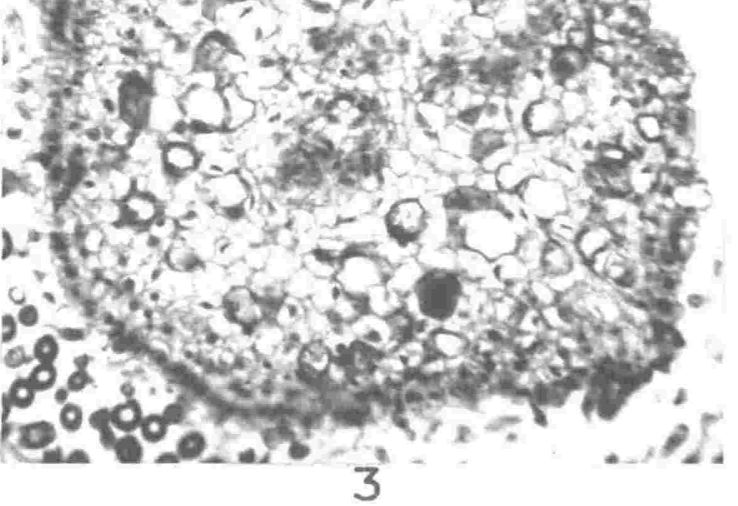
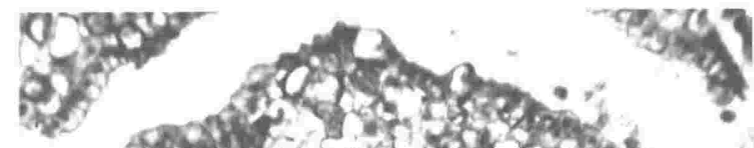

Q6)

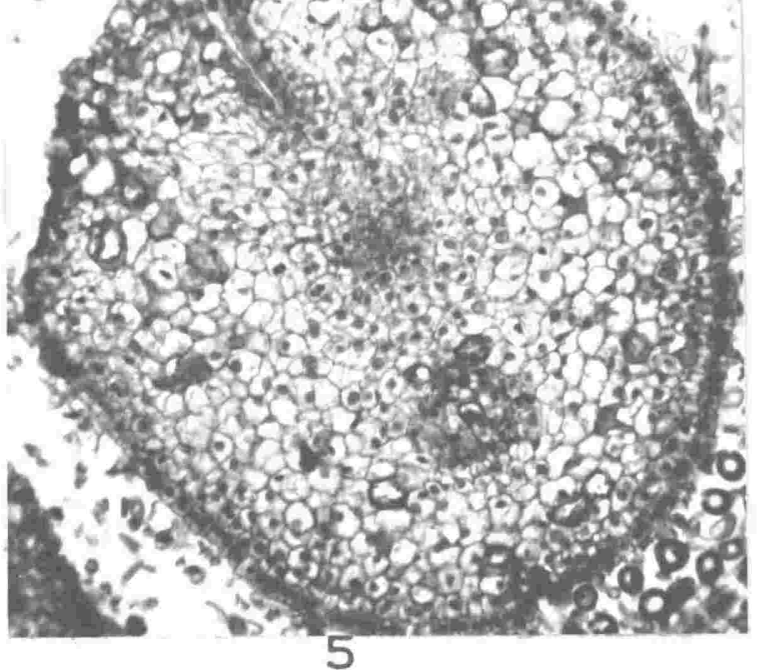

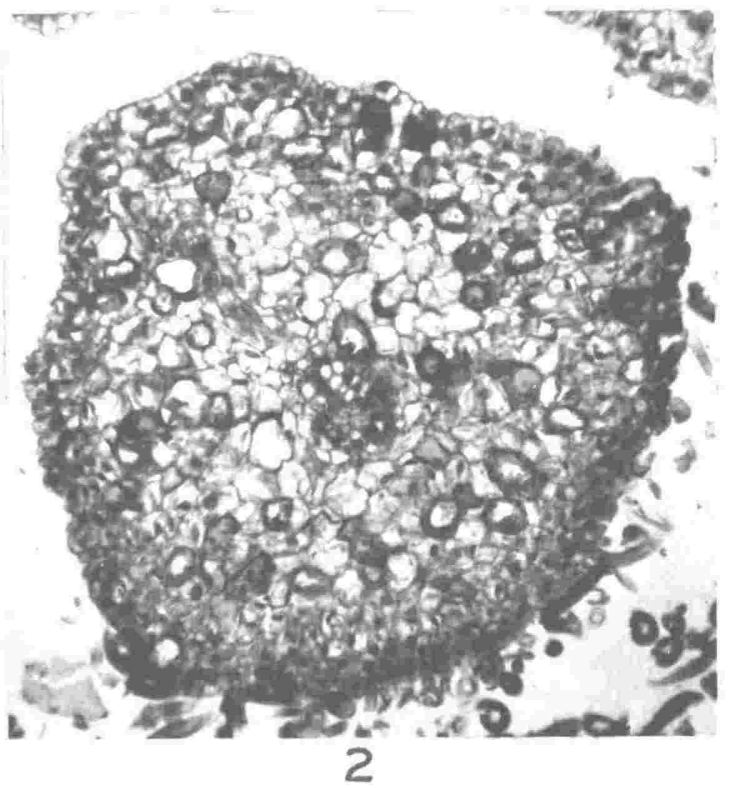

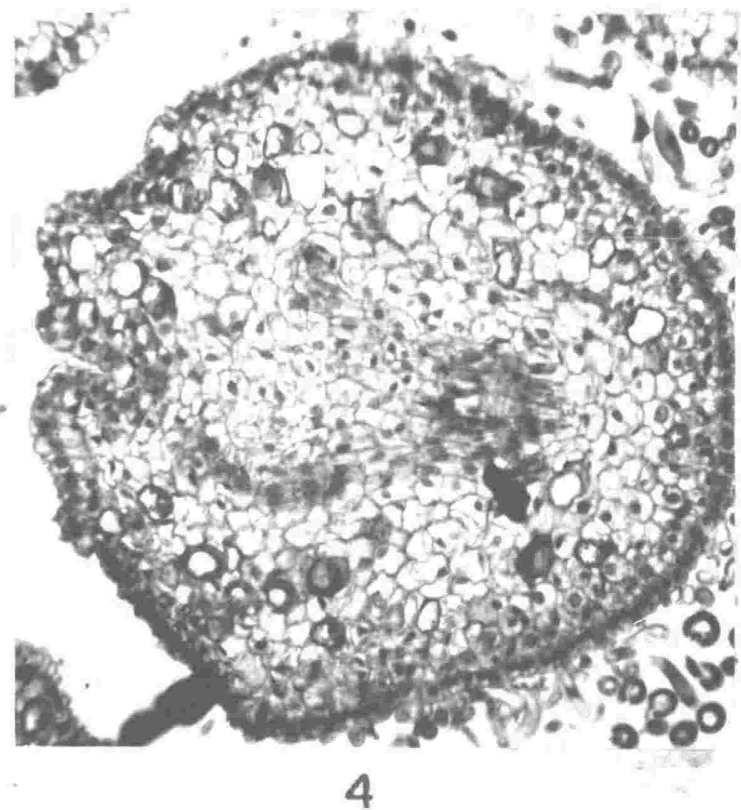




\section{PLATE 51}

Figures $1-4$

Progressive transverse sections of a carpel of Hedycarya arborea, continued from PLATE 50. In figure 4 , which is a section near the base of the carpel, a megaspore mother ceIl ( at prophase I) lies within the ovule. Further details in text.

Al1 figs. × 132 


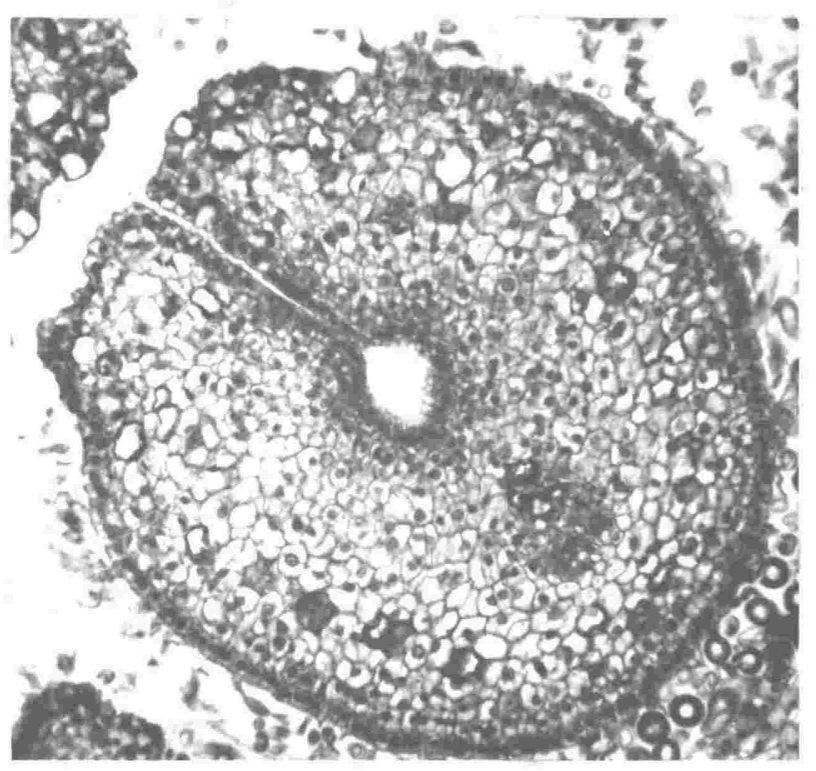

1
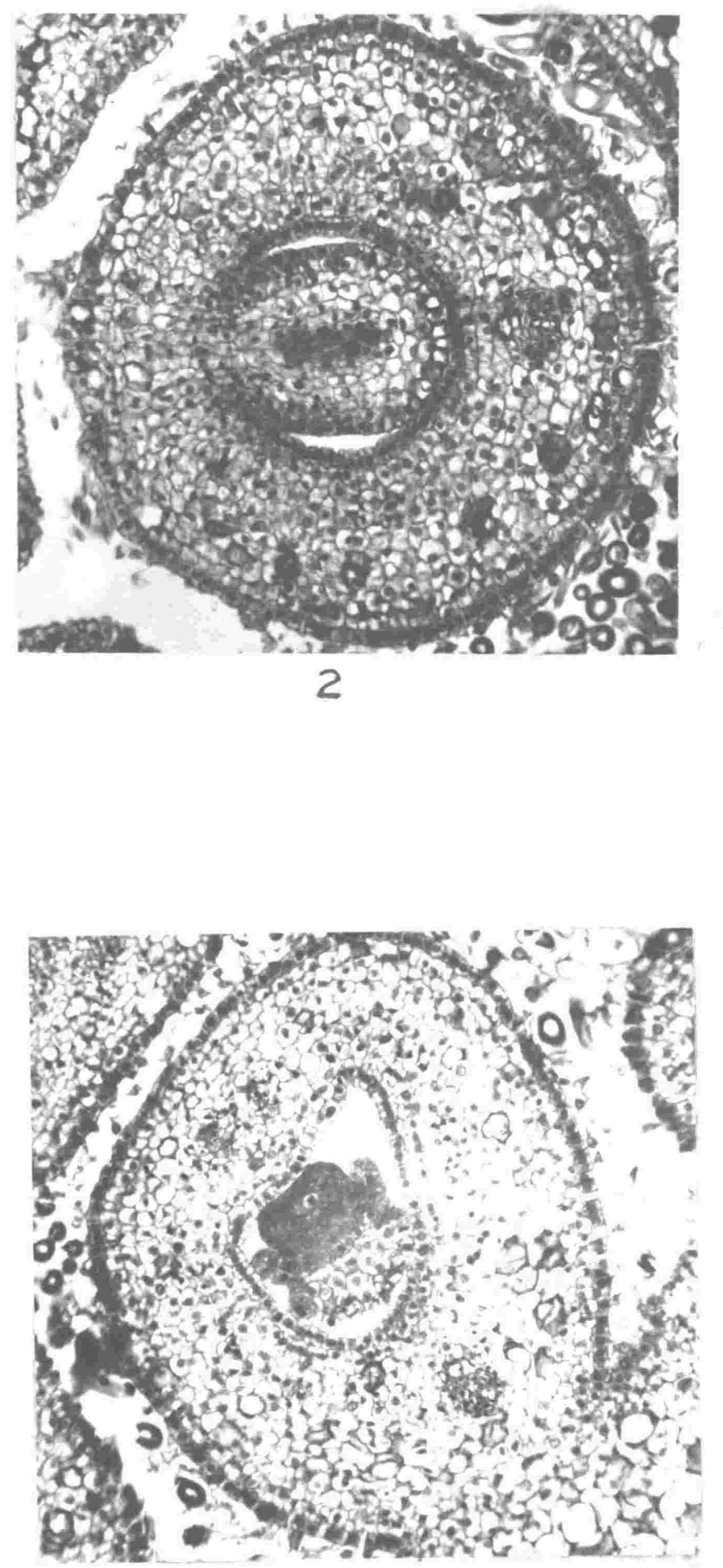

4 


\section{PLATE 52}

Figure 1 L.s. of a carpel primordium of Laurelia $\underline{n} \cdot \underline{\underline{z}}$. The adaxial side of the carpel is on the right. To the right of the carpel is part of the vestigial floral apex.

$$
\times 490
$$

Fioure 2 I. s. of a carpel prinordium of Laurelia $\underline{n} \cdot \underline{z}$. which is older than the one shown in figure 1. The adaxial side of the carpel is on the left. To the left of the carpel is part of the vestigial floral apex. 

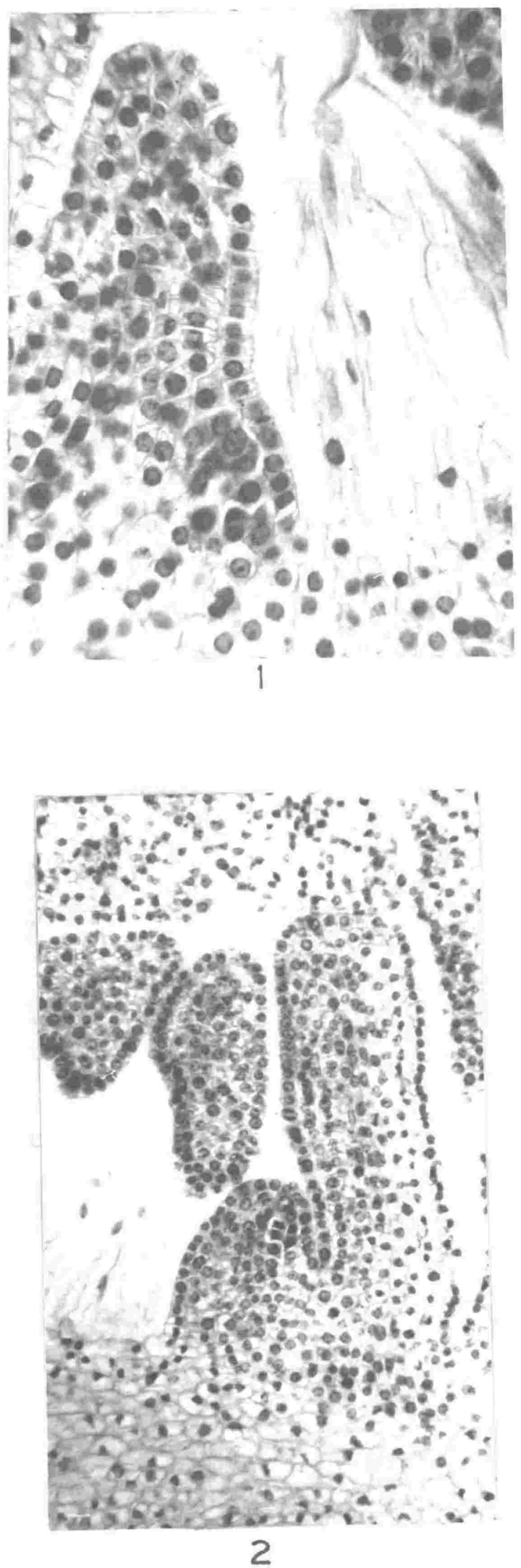
PLATE 53

Figures 1-9 Progressive transverse sections of a carpel of Laurelia $\underline{n} \cdot \underline{\text {. }}$. in which the ovule is at the uninucleate embryo sac stage. Sections begin near the distal tip ( stigma) of the carpel ( figure 1) and are concluded in PLATE 54.

All figs. $x 132$ 

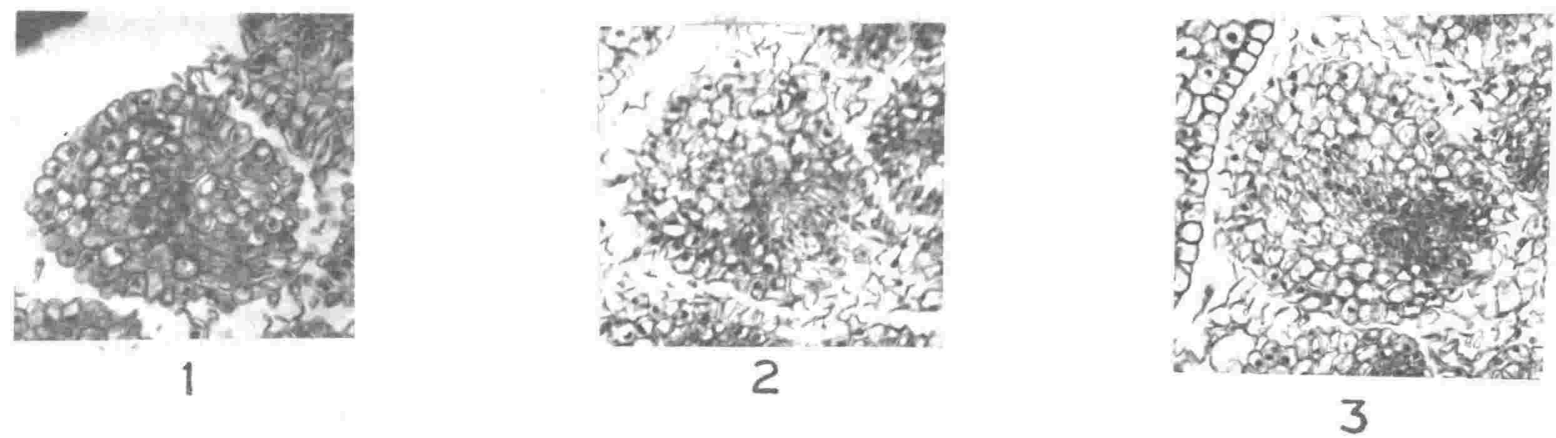

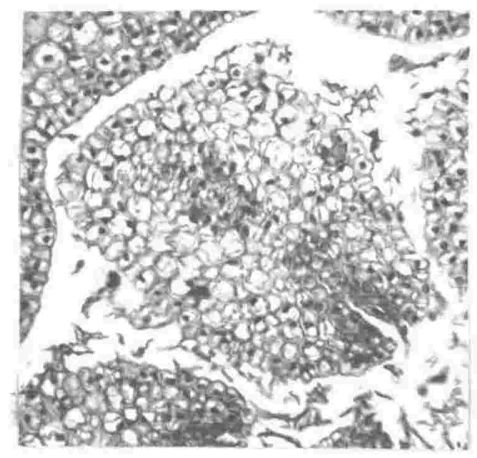

4
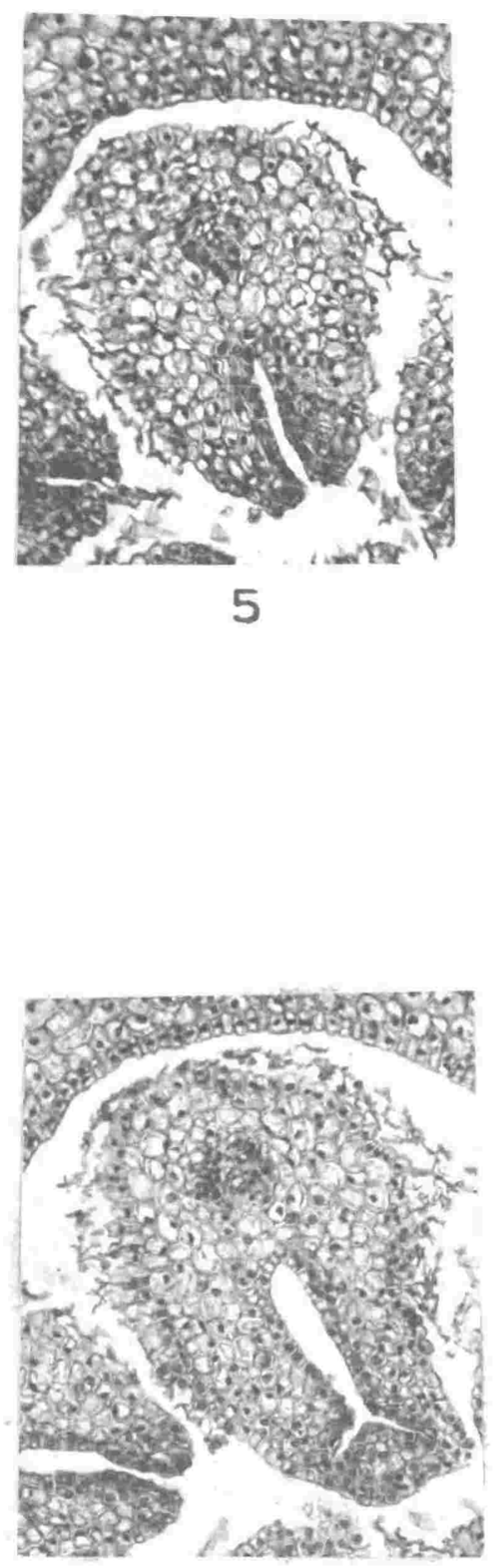

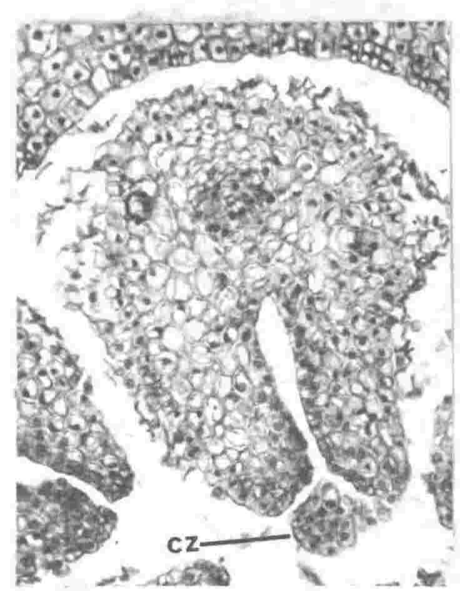

7 


\section{PLATT 54}

Figures 1-5
Progressive transverse sections of a carpel of Laurelia n.z. , continued from PLATE 53. In figure 5, which is a section near the base of the carpel, is an ovule containing a uninucleate embryo sac.

$$
\text { tr }=\text { ventral trace }
$$

All figs. $x 132$ 

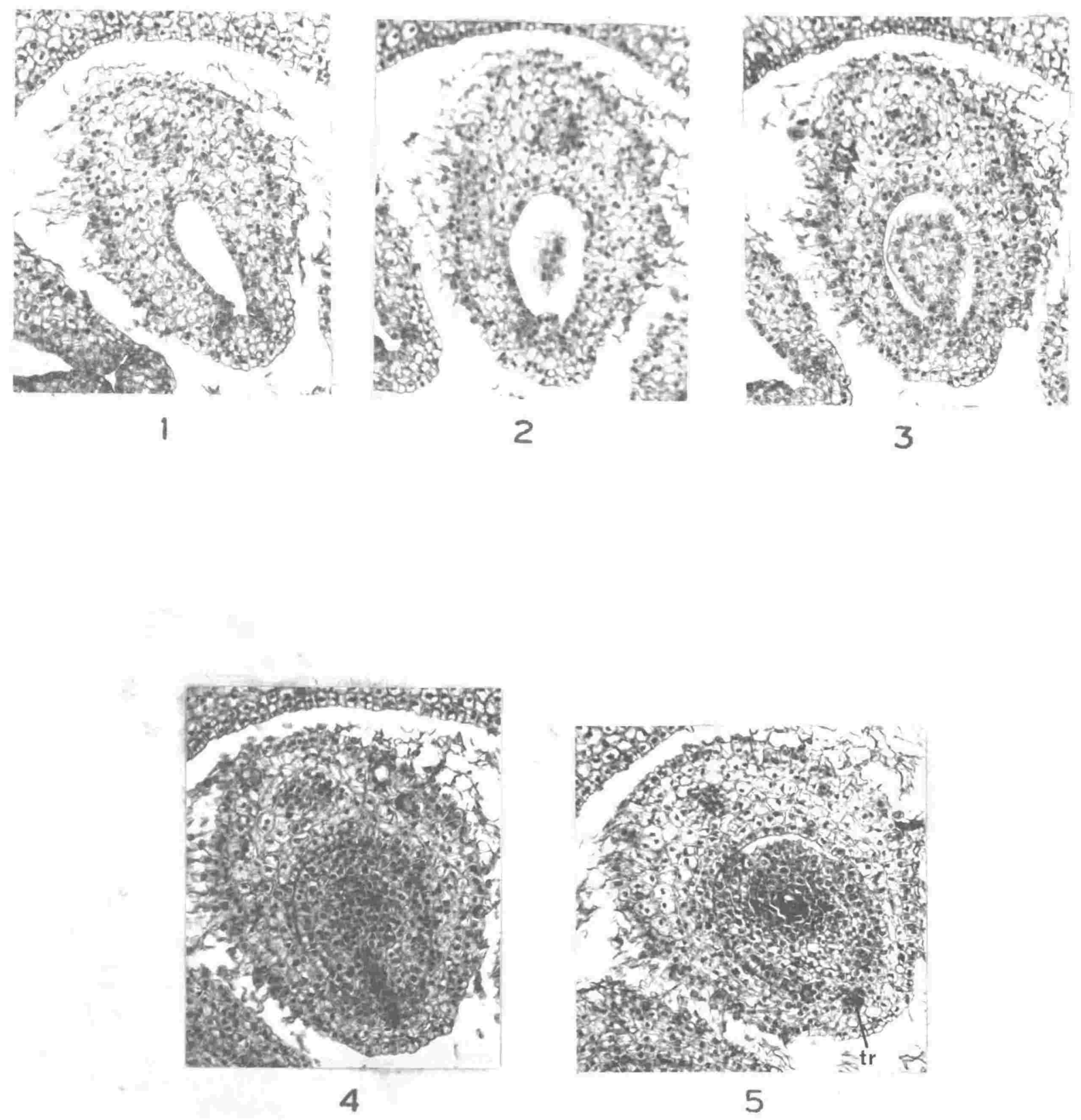


\section{PLATE 55}

Figure 1 Median 1.s. of a carpel of Hedycarya arborea. The adaxial side is at left. Further details in text. x 140

Figure 2 Median lis, of a young ovule of Hedycarya arborea. At the right and at the base of the photo can be seen part of the carpel wall.

$$
\text { x } 456
$$

Figure 3 L. S. of part of a carpel of Hedycarya arborea to show a semi-inverted ovule which contains a megaspore mother cell at prophase I.

$$
\begin{aligned}
& p=a \text { periclinally dividing surface } \\
& \times \text { cell } \\
& \times 168
\end{aligned}
$$

Figure 4 T.s. of an aberrant ovule of Hedycarya arborea which contains two megaspore mother cells. Each megaspore mother cell is at the symizesis stage of prophase I. Further details in text. 0.i. = outer integument $\times 528$ 
tow

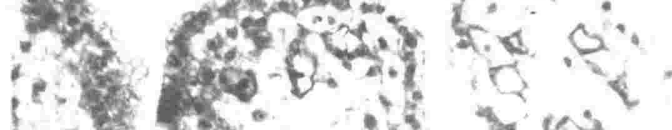

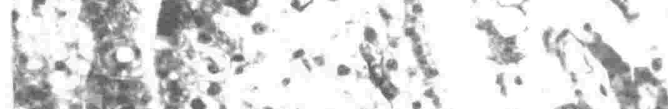

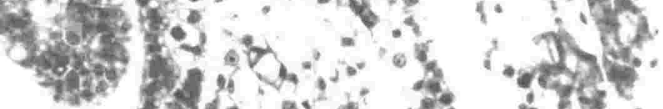

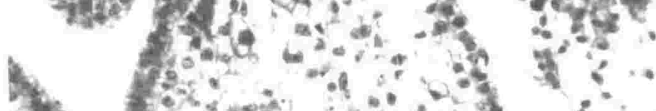

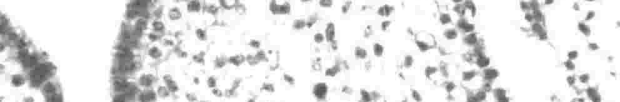

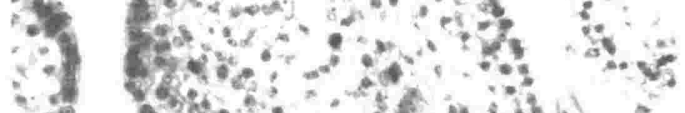

\%

$\because 1$ f

$\therefore$ - 02 -

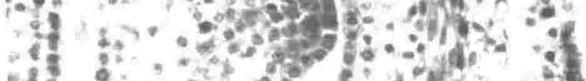

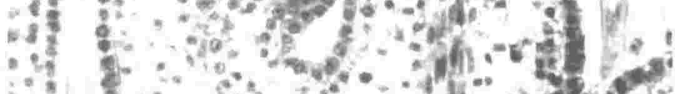

$\because \quad 20 \%$ and

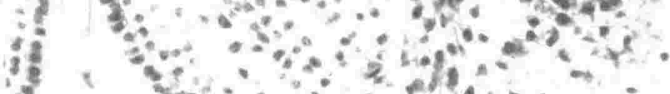

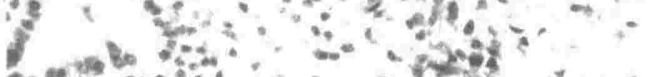

Soe

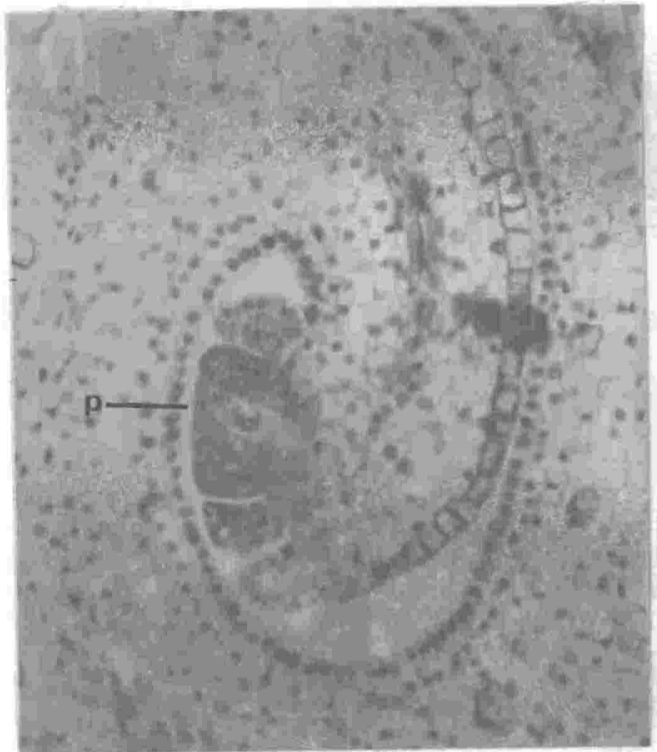

3
(9) $80^{\circ} 0^{\circ}$

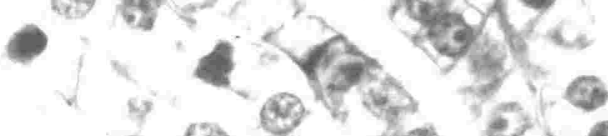

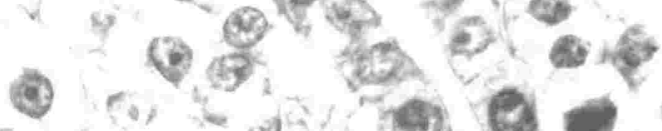
6 (4) $P$. 6 a

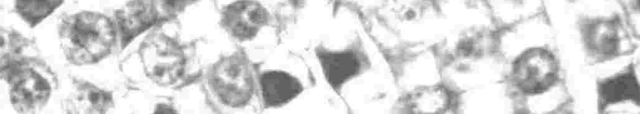
(3) 0 a 30

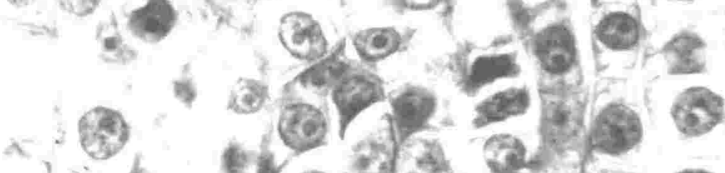

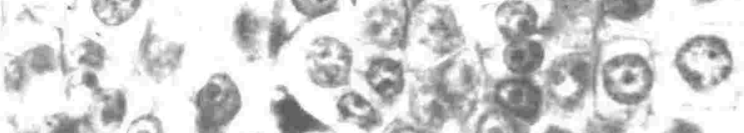

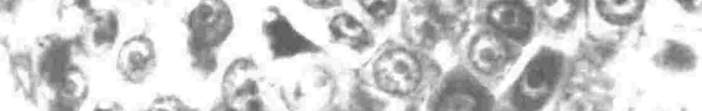

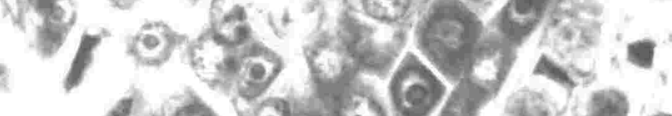

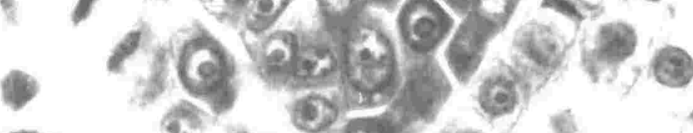

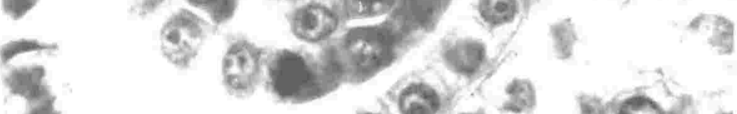

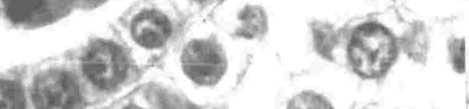

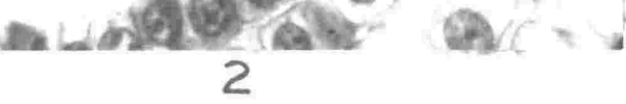

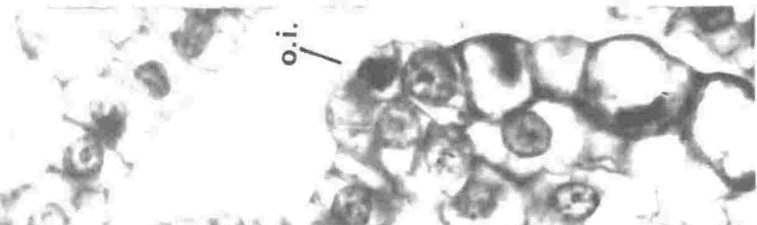

Q

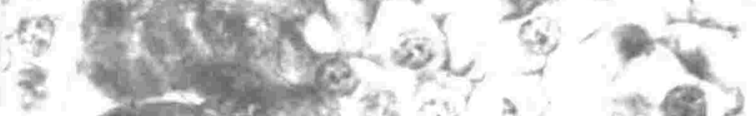

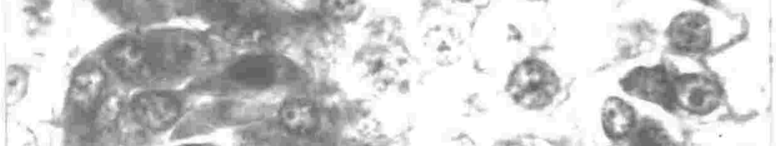

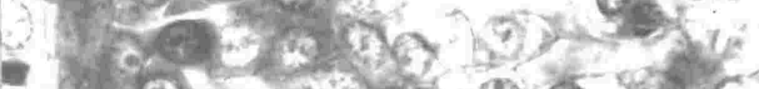

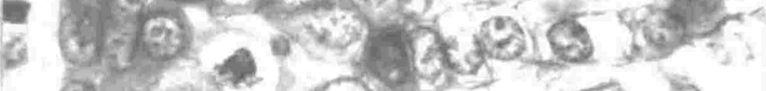

5. (9)

(3)

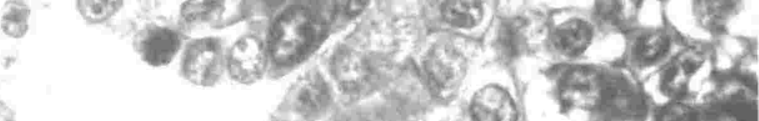

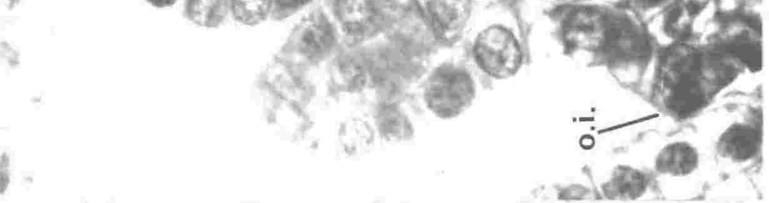




\section{PLATE 56}

Figure 1 L.s. of a fully inverted ovule of Hedycarya arborea. A T-shaped tetrad of megaspores is present ( centre). $\times 520$

Higure 2 L.s. of a fully inverted ovule within the locule of a carpel of Hedycarya arborea. In this abnormal ovule the megaspore mother cell is at prophase I. Further details in text.

$$
\text { x } 204
$$

Figure 3 L. s. of an ovule of Hedycarya arborea which contains a uninucleate embryo sac.

$$
\text { × } 204
$$

Bisure $4 \quad$ L.S. of an ovule of Hedycarya arborea whioh contains a bimcleate embryo sac.

$$
\text { × } 168
$$



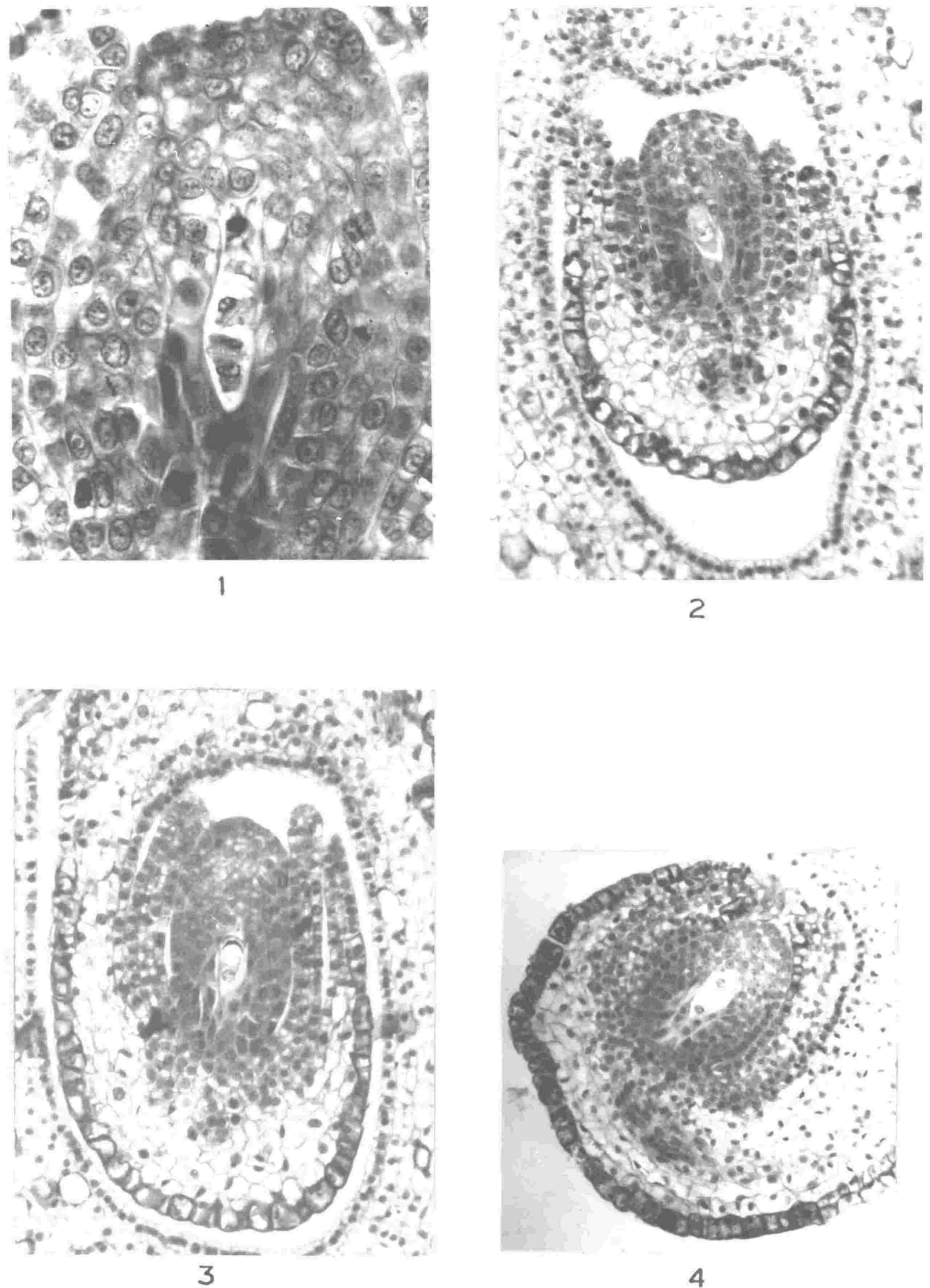
PLATE 57

Figure 1 L.s. of a young ovule of Laurelia $\underline{n} \cdot \underline{z}$. (centre left).

$$
\begin{aligned}
& \text { a. } x_{0}=\text { archesporial cell } \\
& \times 550
\end{aligned}
$$

Figure 2 L.s. of a Joung ovule of Laurelia n.... (centre).

$$
\begin{aligned}
& p=\text { primary parietal cell } \\
& s=\text { primary sporogenous cell } \\
& x \quad 500
\end{aligned}
$$



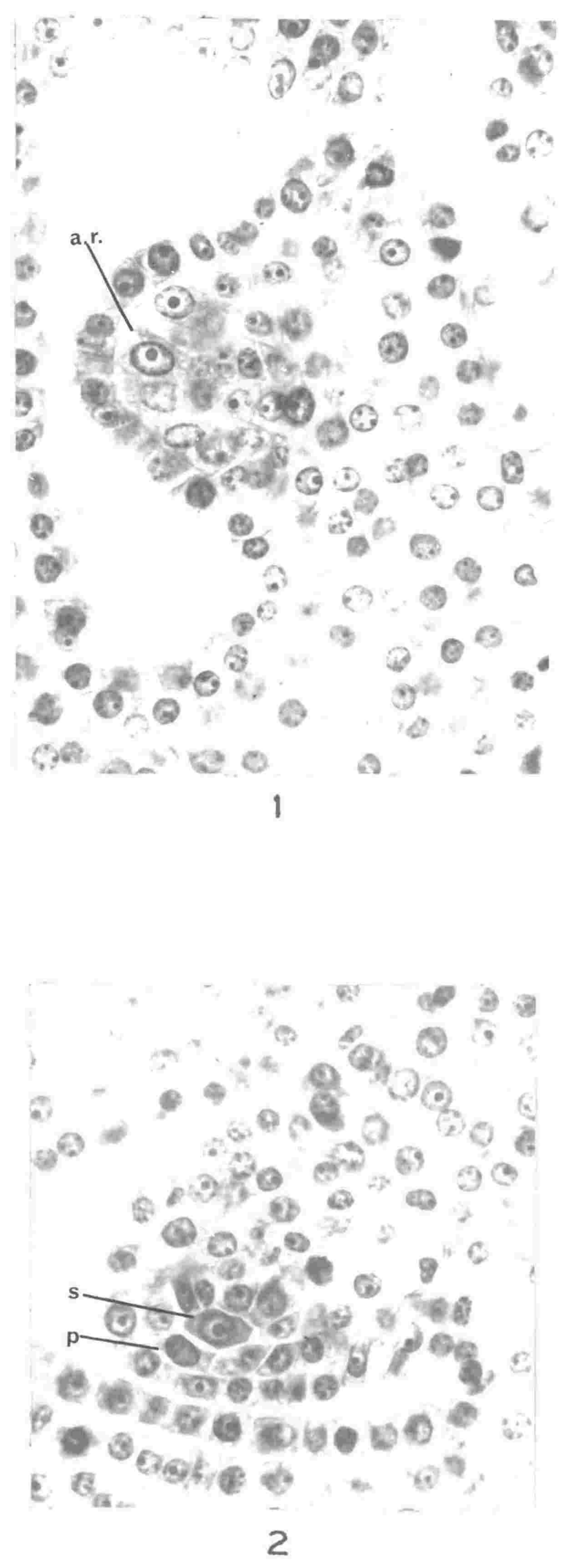
Figure 1 L.s. of a young ovule of Laurelia $\underline{n} \cdot z$. (centre) with an enlarging megaspore mother cell.

Higure 2 L.s. of a young ovule of Laurelia n.z. (centre) with a megaspore mother cell.

$$
\begin{aligned}
0 . \text { I. }= & \text { position at which the outer } \\
& \text { integument has recently been } \\
& \text { initiated }
\end{aligned}
$$

Fisure 3

I. s. of a semi-inverted ovule of Laurelia n. in which the megaspore nother cell is at an early stage of prophase I.

Figure 4 I.s. of part of an inverted ovule of Laurelia $\underline{\underline{n}} . \underline{z}$. ( upper half of photo) which contains a megaspore mother cell at diplotene of prophase I.

All figs. $\times 550$ 

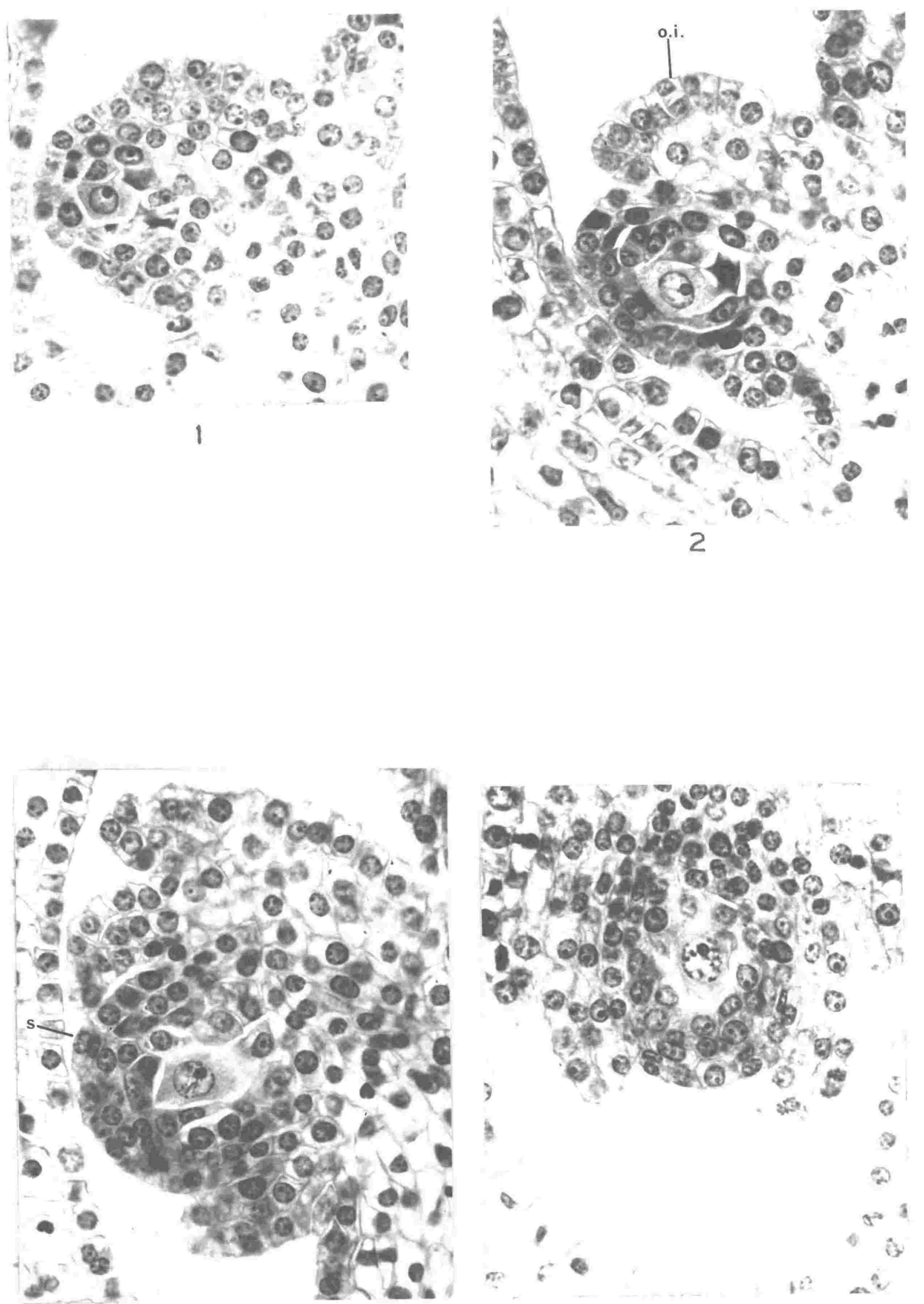

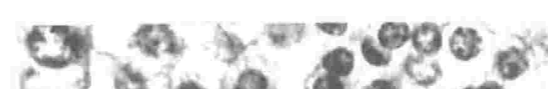

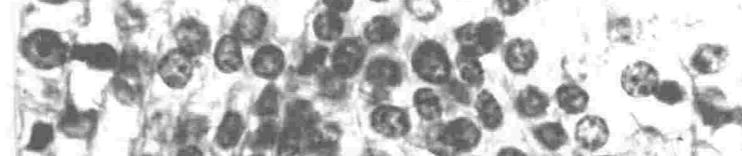

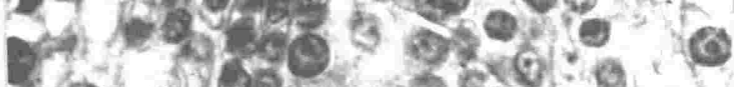

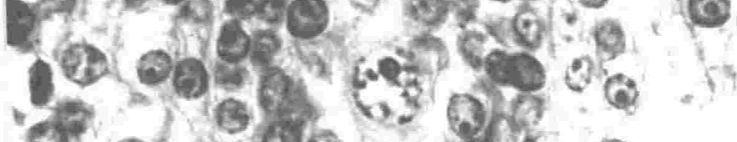

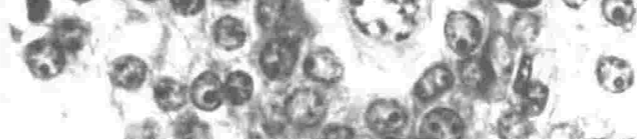

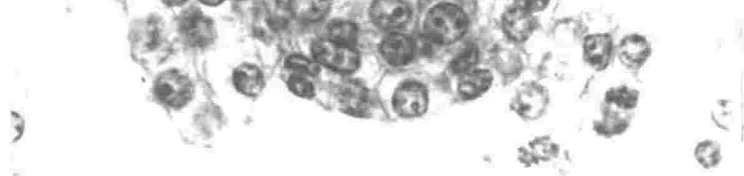

क

Q 
Figure 1 L.s. of part of an ovule of Laurelia $\underline{n} \cdot \underline{z}$. showing a T-shaped tetrad of megaspores in which the megaspore adjacent to the innemost ( functional) one, has begun to degenerate.

$$
\times 550
$$

Figure 2 L.S. of part of an ovile of Laurelia n..z. in which there is a uninucleate embryo sac.

$$
\text { × } 560
$$

Figure 3

L. s. of part of an ovule of Laurelia n.. the nucleus of the embryo sac is at prophase. × 560

Figure 4 I.s. of a young seed of Hedycarya arborea.

$$
\begin{aligned}
& h=\text { hypostase } \\
& \times 112
\end{aligned}
$$


T. 20.070 0.1. nox $400 \%$ a 05 mal ctos ose? Ce 10.

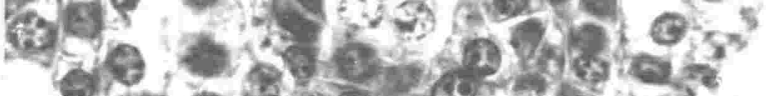
Q 105 Pingest

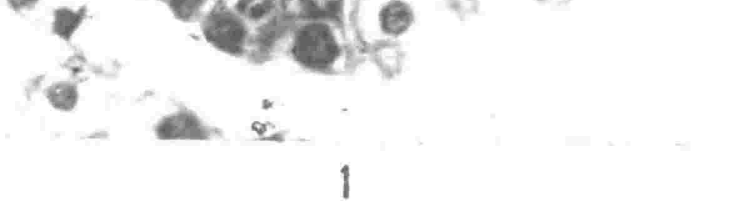

$-20-0.00$ Q. $-00^{\circ} \cdot 0^{2}$ a 90100 1090.

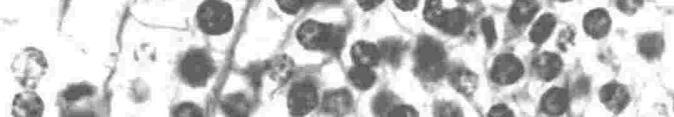

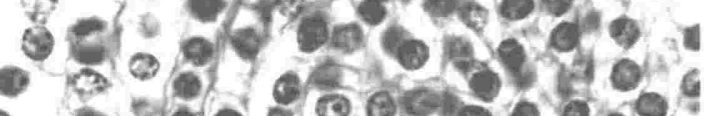

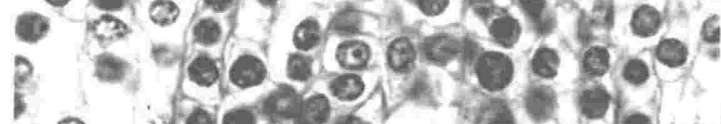
(a) 160.

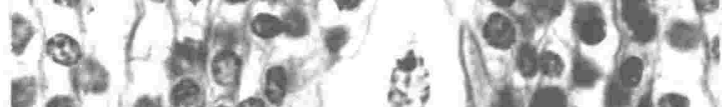
5.200. 40 i hor - 8 - 40. - $-300 \%$ - $010.00 \%$ - $109800 \mathrm{r}$ - .
80000

$1000^{\circ}$ 700000

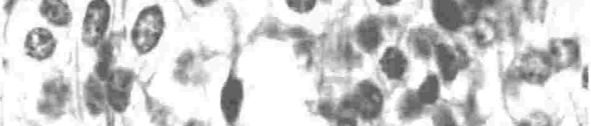

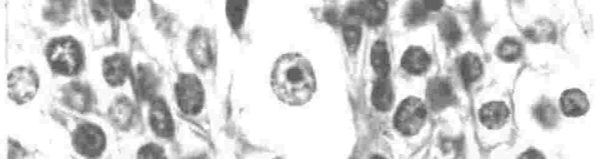

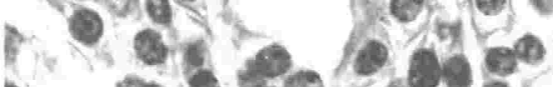

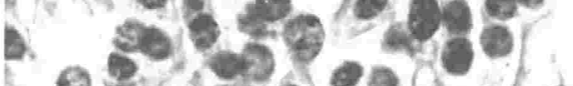

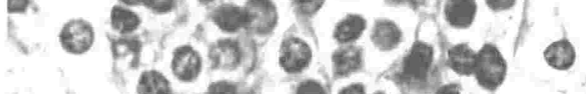

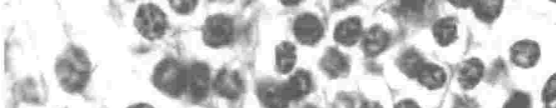

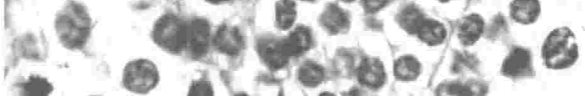
$107.10 \% 5$

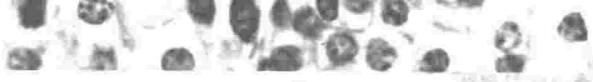
2

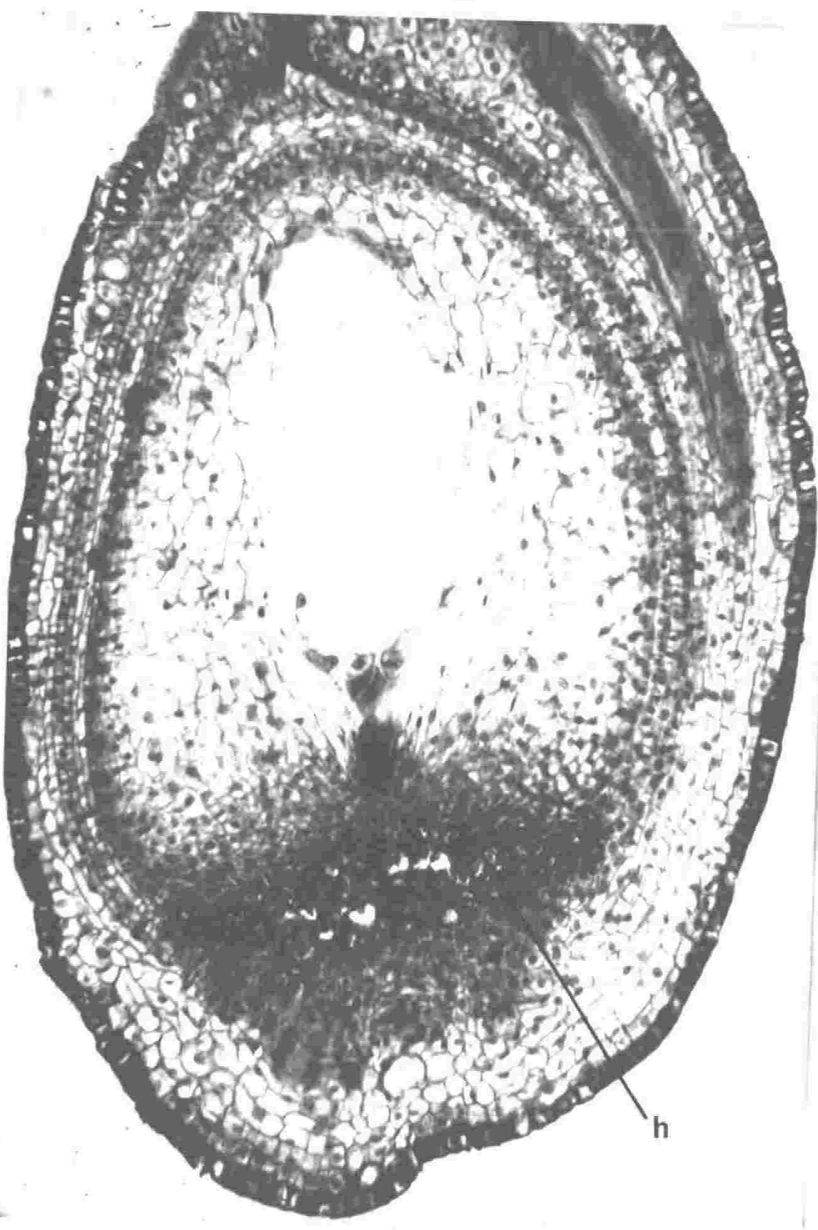


PLATE 60

Fisure 1 2-nucleate embryo sac of Laurelia $\underline{n} \cdot \underline{z}$.

Figure 2 4-nucleate embryo sac of Laurelia $\underline{n} . \underline{z}$.

Figure 3 Young 8-nucleate embryo sac of Laurelia n.…

Figure $4 \quad$ L.s, of part of the carpel of Laurelia $\underline{n} \cdot \underline{z}$. containing a mature embryo sac prior to fertilization.

Stippled areas at left and right represent the ventral (left) and dorsal vascular tissue.

In all figures the chalazal end of the embryo sac faces the top of the page. 
PLATE 60
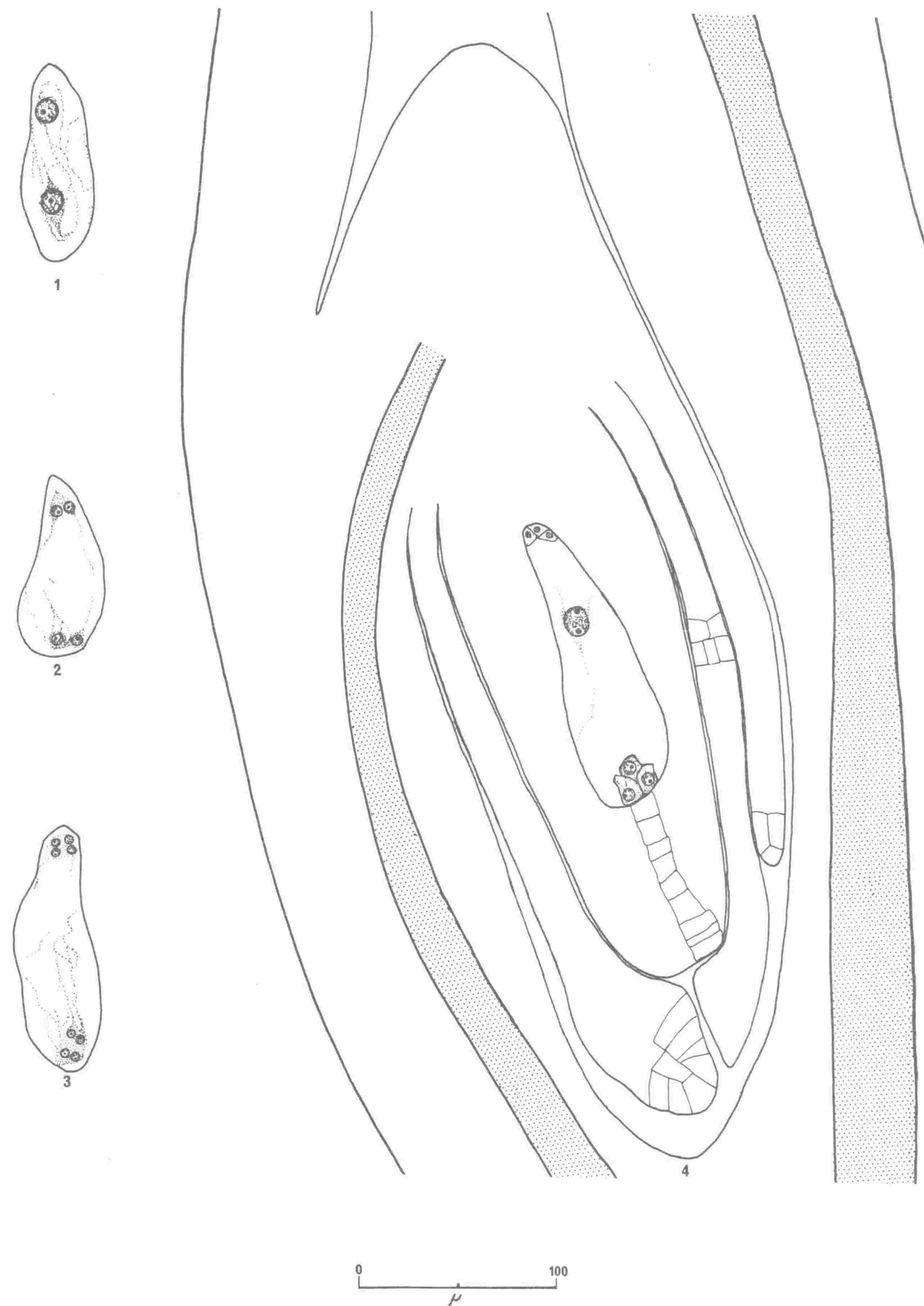
Figure 1 Foliage of Laurelia $\underline{n} \cdot \underline{z}$. bearing a dehisced pseudocarp. Approximately natural size. 


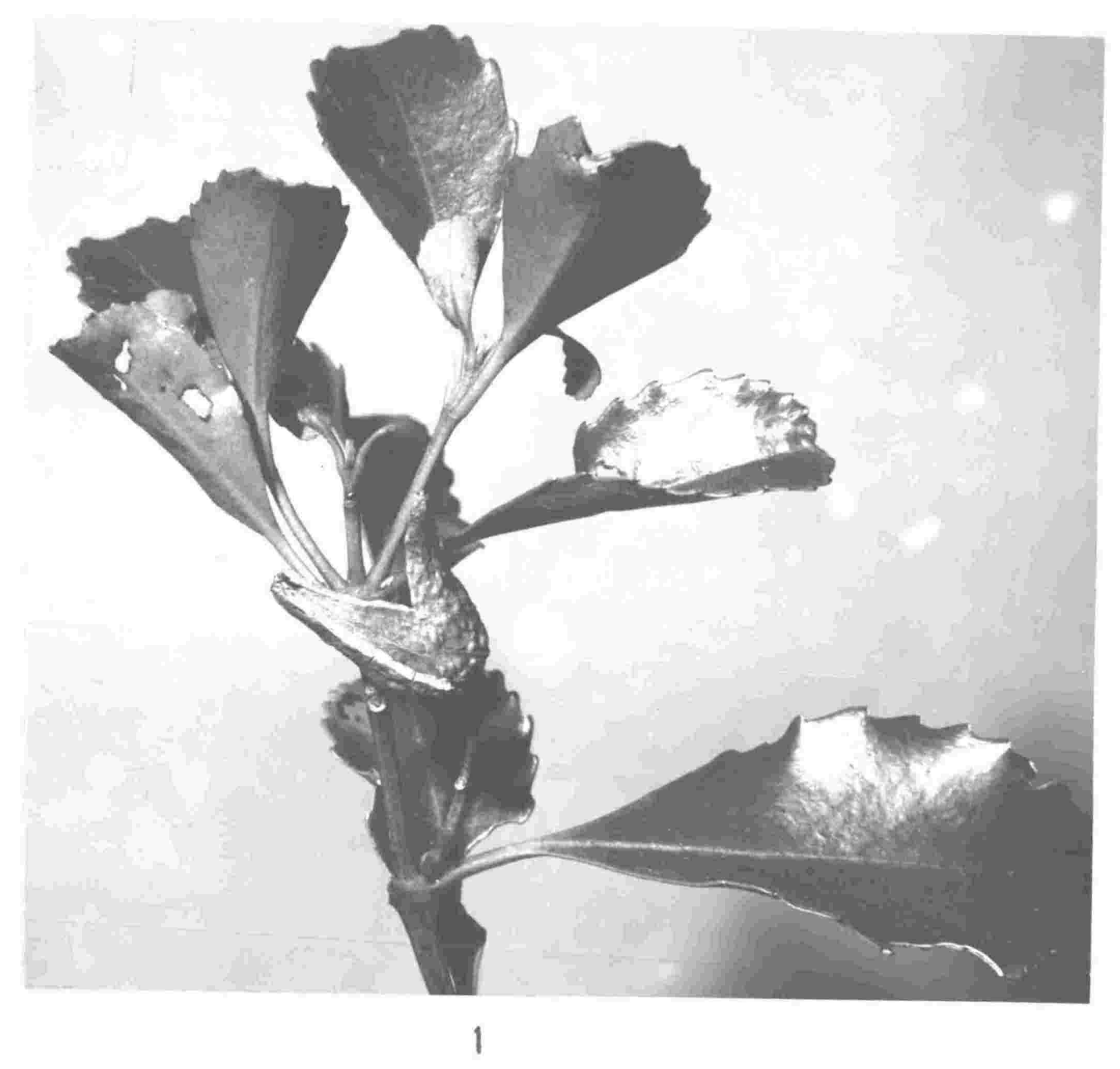




\section{PLATT 62}

Photo of herbarium sheet containing two specimens of the foliage of Laurelia serrata Phil. 


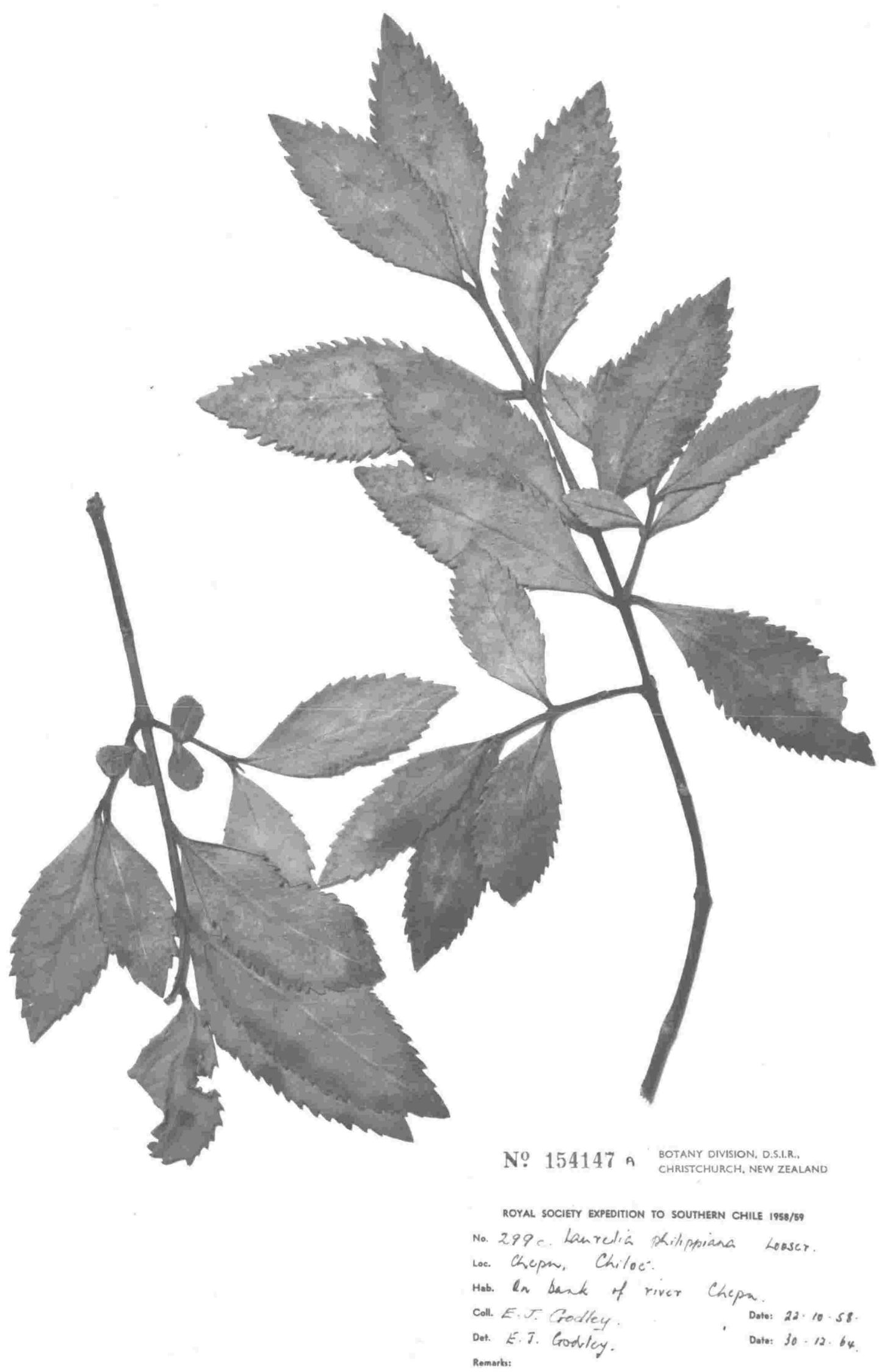

